\title{
ॠUSGS
}

science for a changing world

Prepared in cooperation with the BUREAU OF RECLAMATION

Hydrogeologic Framework Refinement, Ground-Water Flow and Storage, Water-Chemistry Analyses, and Water-Budget Components of the Yuma Area, Southwestern Arizona and Southeastern California

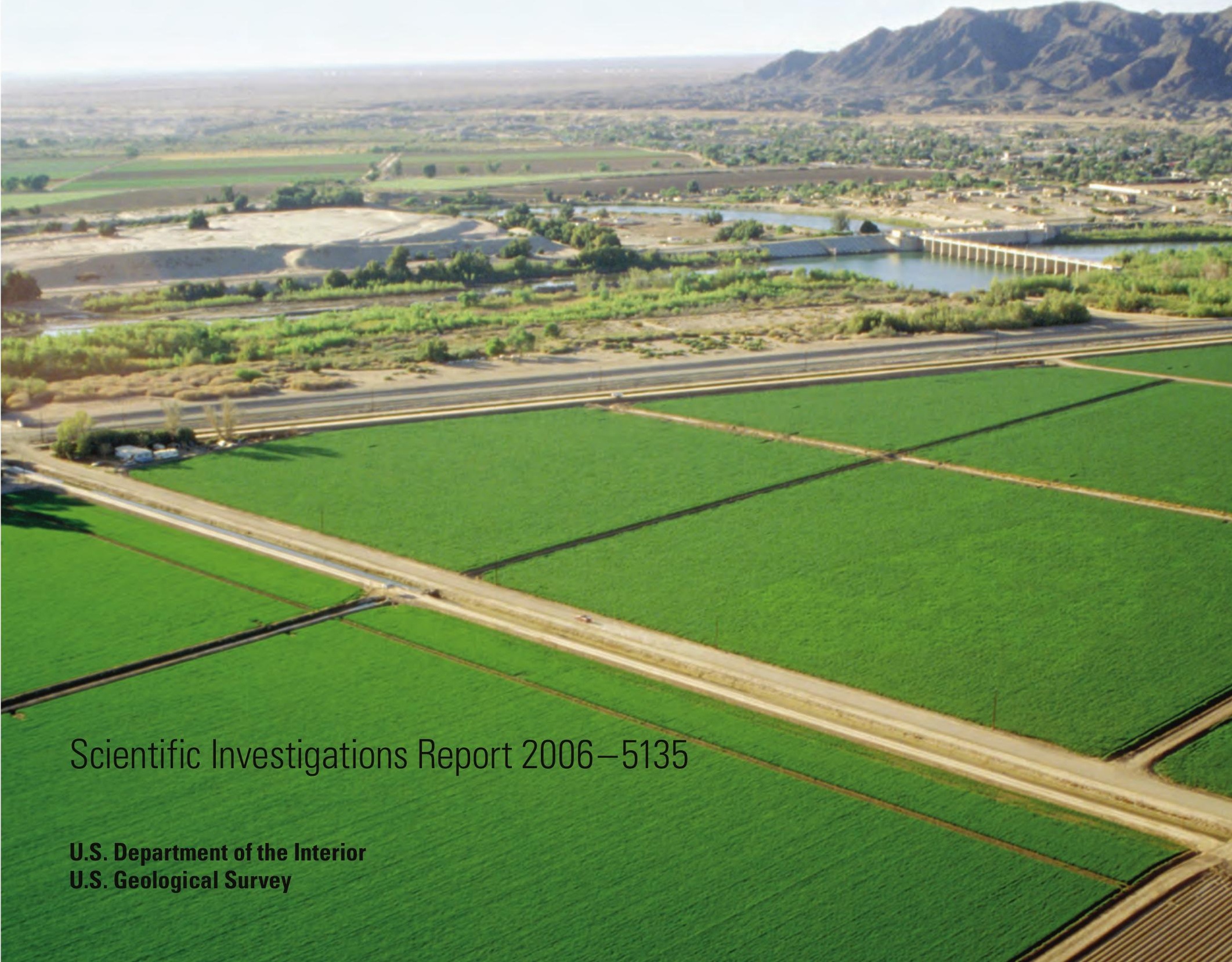


This page left blank intentionally. 


\section{Hydrogeologic Framework Refinement, Ground-Water Flow and Storage, Water-Chemistry Analyses, and Water-Budget Components of the Yuma Area, Southwestern Arizona and Southeastern California}

By Jesse E. Dickinson, Michael Land, Claudia C. Faunt, S.A. Leake, Eric G. Reichard, John B. Fleming, and D.R. Pool

Prepared in cooperation with the

Bureau of Reclamation, U.S. Department of the Interior

Scientific Investigations Report 2006-5135 


\section{U.S. Department of the Interior DIRK KEMPTHORNE, Secretary \\ U.S. Geological Survey \\ P. Patrick Leahy, Acting Director}

\section{U.S. Geological Survey, Reston, Virginia: 2006}

For product and ordering information:

World Wide Web: http://www.usgs.gov/pubprod

Telephone: 1-888-ASK-USGS

For more information on the USGS--the Federal source for science about the Earth, its natural and living resources, natural hazards, and the environment:

World Wide Web: http://www.usgs.gov

Telephone: 1-888-ASK-USGS

Any use of trade, product, or firm names is for descriptive purposes only and does not imply endorsement by the U.S. Government.

Although this report is in the public domain, permission must be secured from the individual copyright owners to reproduce any copyrighted materials contained within this report.

Suggested citation:

Dickinson, J.E., Land, Michael, Faunt, C.C., Leake, S.A., Reichard, E.G., Fleming, J.B., and Pool, D.R., 2006,

Hydrogeologic framework refinement, ground-water flow and storage, water-chemistry analyses, and water-budget components of the Yuma area, southwestern Arizona and southeastern California: U.S. Geological Survey Scientific Investigations Report 2006-5135, 90 p. 


\section{Contents}

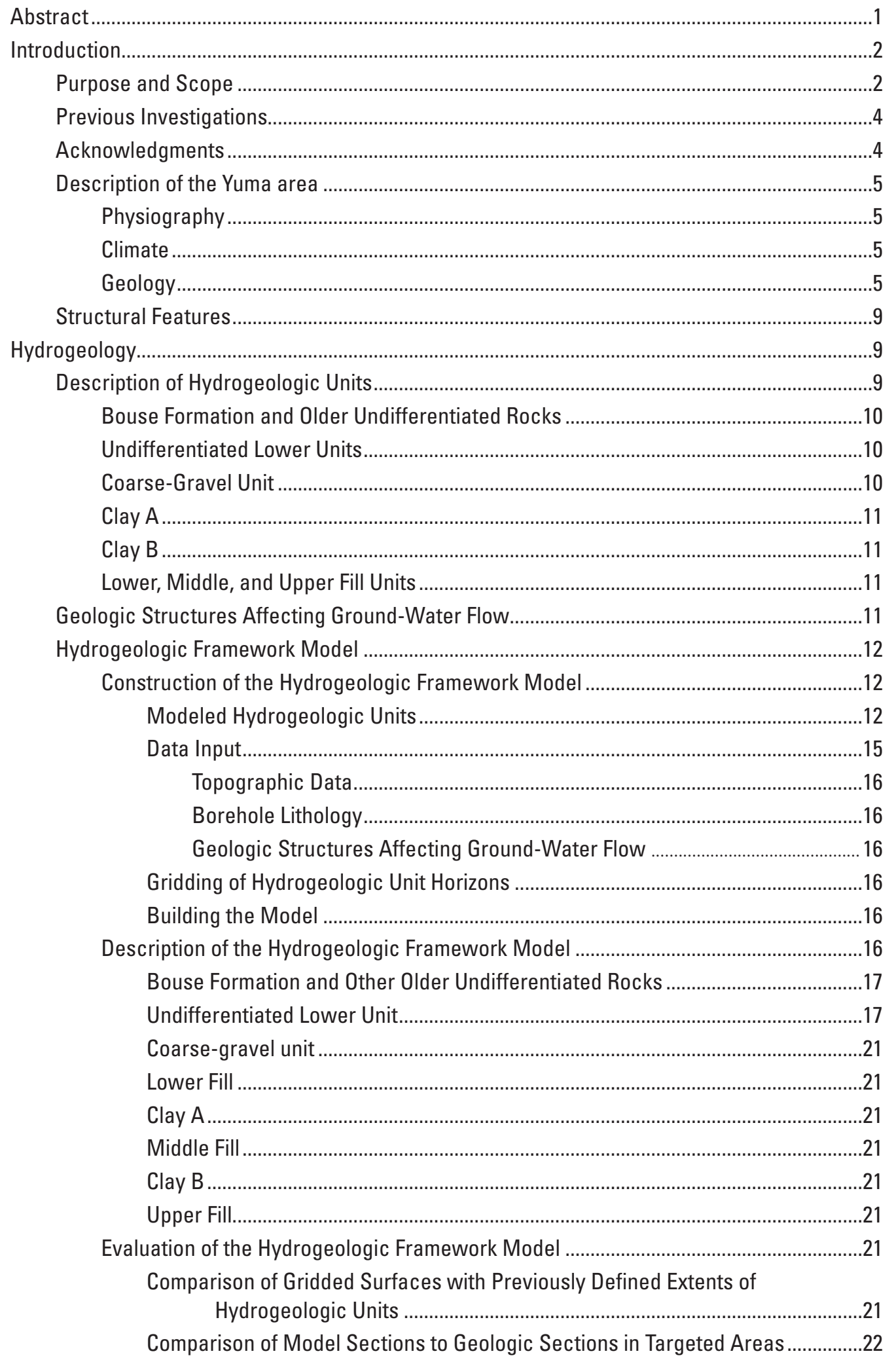




\section{Contents-Continued}

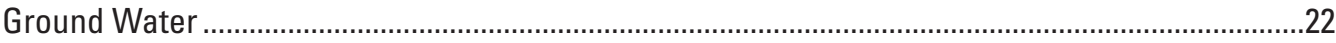

Modern Ground-Water Levels and Flow Patterns …….....................................................2

Ground Water Stored Under Yuma Mesa ............................................................................27

Water Chemistry at Selected Sites in Yuma Valley, South Gila Valley, and Yuma Mesa .................29

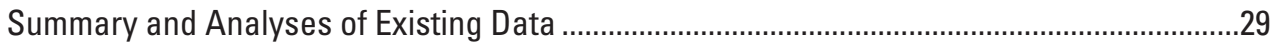

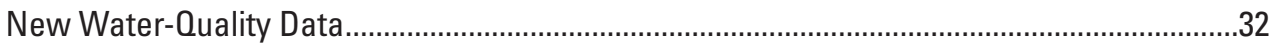

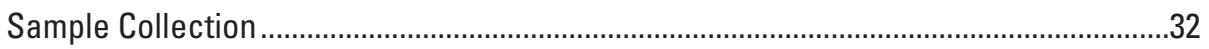

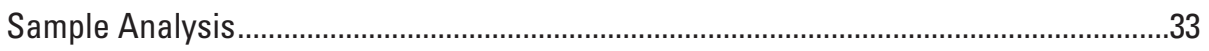

Wellbore Velocity Profile and Depth-Dependent Sampling ...........................................33

Inorganic Water Chemistry ..........................................................................................3

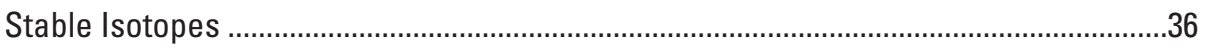

Radioisotopes: ${ }^{3} \mathrm{H}$ and ${ }^{14} \mathrm{C}$.................................................................................. 40

Implications of Water-Chemistry Data on the Source and Movement of Ground

Water in the Study Area .......................................................................................

Discussion of Results of Wellbore Velocity Profile and Depth-Dependent Sampling ............41

Review of Water Budget Components ........................................................................................

Ground-Water Budget Data and Approach........................................................................ 44

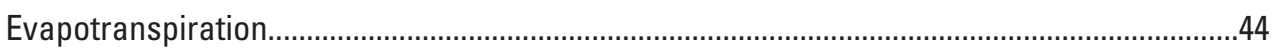

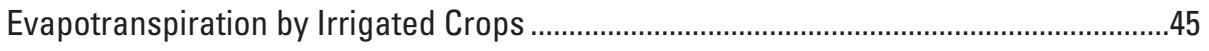

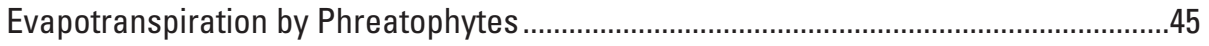

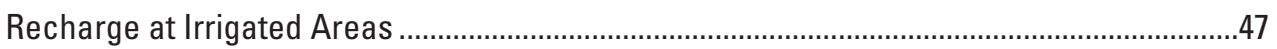

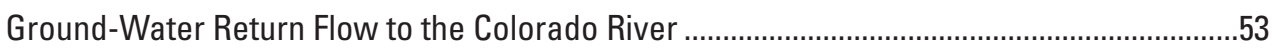

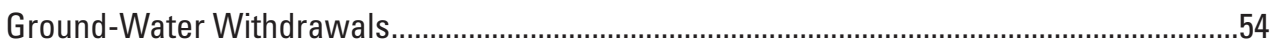

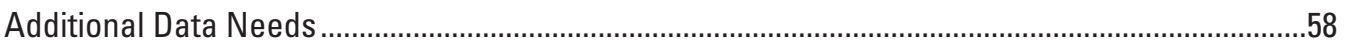

Compilation and Analyses of Data from Previous Studies ...................................................58

Data Collection and Analyses to Improve Understanding of the Flow System .......................58

Compilation of Data for Management Modeling ................................................................59

Summary of Phase 1 Analysis and Concepts for Water Management.............................................59

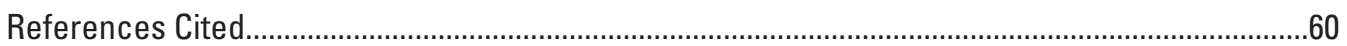

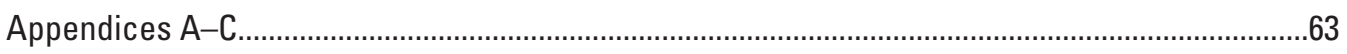

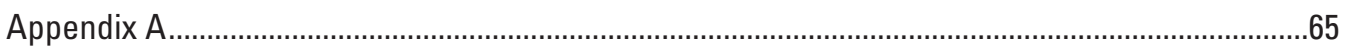

23/4-Dimensional Density-Distribution Models ……….....................................................65

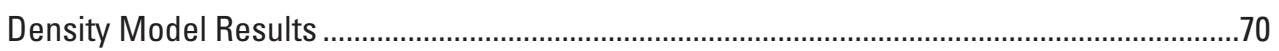

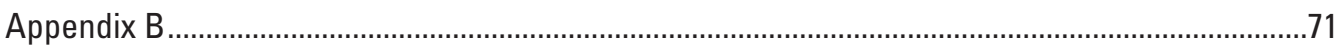

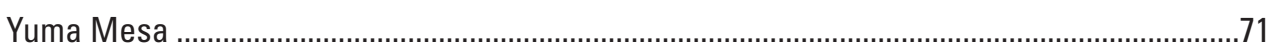

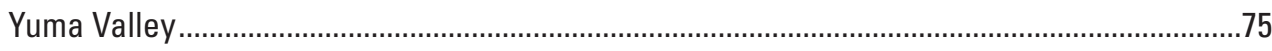

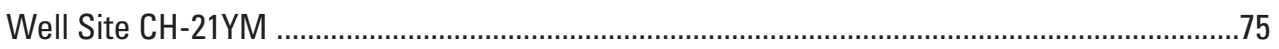

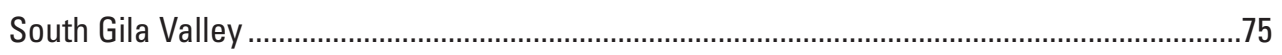

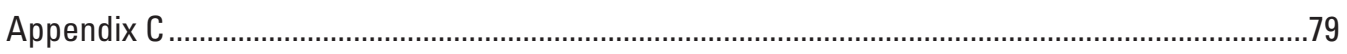




\section{Figures}

1. Map showing yuma area in southwestern Arizona and southeastern California .............3

2. Map showing structures that can affect ground-water flow and traces of geologic sections shown in figures $3,10,11$, and 12................................................

3. Cross sections showing hydrogeologic units in Yuma Valley and Yuma Mesa .................7

4. Map showing the extent of the hydrogeologic framework model (HFM) and the ground-water flow model

5. Map showing locations of wells having geological and geophysical logs used in the hydrogeologic framework model

6. Oblique view of block diagram of the hydrogeologic framework model

7. Map showing the extent and thickness of the coarse-gravel unit and locations of geologic and geophysical logs used to identify the top elevation of the unit.

8. Map showing extent of clay A according to Olmsted and others (1973), the new extent of clay $A$ described in this report, and locations of wells that either penetrate or do not penetrate clay $A$.

9. Map showing extent of clay B according to Olmsted and others (1973), the new extent of clay $B$ described in this report, and locations of wells that either penetrate or do not penetrate clay $B$

10. Cross section A-A' showing hydrogeologic units in Yuma Valley and Yuma Mesa.

11. Cross section B-B' showing hydrogeologic units in Yuma Valley and Yuma Mesa.

12. Cross section $\mathrm{C}^{-C^{\prime}}$ showing hydrogeologic units in Yuma Valley and Yuma Mesa.....

13. Map showing the thickness of the mound under Yuma Mesa, the assumed extent of the mound used in this report, and contours that connect equal elevations of the water table in 1925

14. Map showing wells having water-level measurements, surface-water elevations that are likely hydraulically connected to ground water, water-table contours, and generalized ground-water flow directions 2004-2005.

15. Graph showing relationship between the specific yield of subsurface sediments in the Yuma mound area and the amount of ground water stored in the mound.

16. Trilinear diagram showing major-ion composition of ground water from selected wells in the Yuma area, 1984-2005.

17. Locations of wells sampled, April-September 2005

18. Dissolved solids and nitrate (as N) concentrations for wells sampled, April-September 2005.

19. Trilinear diagram showing major-ion composition of ground water from sampled wells and surface water from two locations in the study area, April-September 2005

20. Graph showing $\delta$ deuterium as a function of $\delta$ oxygen-18 in ground water sampled (and other sources) in the study area.

21. Graph showing tritium concentration in water sampled from the streamflow-gaging station along the Colorado River at Imperial Dam (USGS 09429490), 1964-1990 


\section{Figures - Continued}

22. Map showing tritium concentrations and carbon-14 activity in water samples collected from wells in the study area

23. Graph showing $\delta$ deuterium as a function of $\delta$ oxygen-18, grouped by tritium concentration in ground water sampled in the Yuma area,

April-September 2005.

24. Velocity profile, selected water-quality data, and lithologies at depth intervals at well YM-10, September 2005.

25. Map showing zones representing irrigated areas having calculations of recharge and evapotranspiration, Yuma area......

26. Chart showing ground-water return flow along the Colorado River

27. Regional ground-water withdrawals and data sources for the Yuma area, 1915 to 1999

28. Map showing complete Bouguer gravity anomaly, gravity measurement sites, wells that penetrate crystalline bedrock, and a seismic profile in the Yuma area

29. Graph showing subsurface density distribution along profile D-D'.

30. Graph showing subsurface density distribution along profile E-E'

31. Graph showing subsurface density distribution along profile F-F'

32. Map showing surface geophysical surveys at Yuma Valley and Yuma Mesa.

33. Arial photo and graphs showing seismic surveys along transects Seismic Line 1 and Seismic Line 2 at Yuma Mesa near East County 16th Street and 4th Avenue extension.

34. Arial photo and graphs showing time-domain electromagnetic surveys YMTDEM-1 and YMTDEM-2 at Yuma Mesa near East County 16th Street and 4th Avenue extension.

35. Arial photo and graphs showing time-domain electromagnetic surveys YVTDEM-1 and YVTDEM-2 on Avenue B and East County 14th Street.....

36. Arial photo and graphs showing time-domain electromagnetic surveys SGTDEM-1 and SGTDEM-2 at South Gila Valley

37. Graphs showing water-chemistry data for well $242-2$.....................................................79

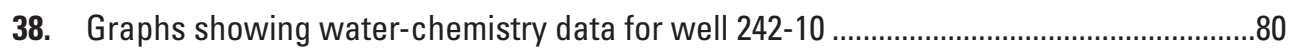

39. Graphs showing water-chemistry data for well $242-22$...................................................81

40. Graphs showing water-chemistry data for well DW-3...................................................82

41. Graphs showing water-chemistry data for well Fortuna Pond ..........................................83

42. Graphs showing water-chemistry data for well SG10r ...................................................84

43. Graphs showing water-chemistry data for well SG-709 .................................................85

44. Graphs showing water-chemistry data for well 14 1 $1 / 4$ Street at Yuma Valley...................86

45. Graphs showing water-chemistry data for well YM-10 .................................................87

46. Graphs showing water-chemistry data for well YV-7r at Yuma Valley .............................88 


\section{Tables}

1. Predominant stratigraphic units for each hydrogeologic unit........................................

2. Data sources for water-bearing deposits included in the hydrogeologic framework model

3. Location, construction, and hydrogeologic information for ground-water

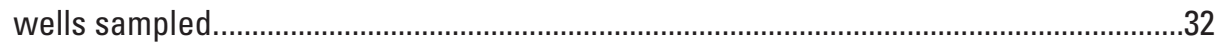

4. Field measurement, major ion, nutrient, and selected trace-element data in ground-water samples from wells sampled, April-September 2005 .............................34

5. Field measurement, selected anion, deuterium, and oxygen-18 data in surface-water samples collected April 2005 ................................................................36

6. Deuterium, oxygen-18, tritium, carbon-13, and carbon-14 data in ground-water samples from wells sampled, April-September 2005

7. Average monthly evapotranspiration parameters for irrigated crops by using climate data for 1989-1999, in the Yuma area .....................................................4

8. Evapotranspiration rate per zone for irrigated crops, 1970-1999, Yuma area..................49

9. Monthly values of crop coefficients for vegetation groups, Yuma area ..........................50

10. Monthly averages of evapotranspiration for vegetation groups, Yuma area..................51

11. Recharge volume per zone from irrigated crops for 1970-1999, Yuma area ..................52

12. Ground-water withdrawals from 1970 to 1999 in the Yuma area and Mexicali Valley . .55

13. Ground-water withdrawals for zones in the ground-water flow model from 1970 to 1999 in the Yuma area and Mexicali Valley.. 


\section{Conversion Factors and Datum}

\begin{tabular}{|c|c|c|}
\hline Multiply & By & To obtain \\
\hline \multicolumn{3}{|c|}{ Length } \\
\hline inch (in.) & 2.54 & centimeter $(\mathrm{cm})$ \\
\hline inch (in.) & 25.4 & millimeter $(\mathrm{mm})$ \\
\hline foot $(\mathrm{ft})$ & 0.3048 & meter $(\mathrm{m})$ \\
\hline mile (mi) & 1.609 & kilometer $(\mathrm{km})$ \\
\hline \multicolumn{3}{|c|}{ Area } \\
\hline acre & 4,047 & square meter $\left(\mathrm{m}^{2}\right)$ \\
\hline acre & 0.004047 & square kilometer $\left(\mathrm{km}^{2}\right)$ \\
\hline \multicolumn{3}{|c|}{ Volume } \\
\hline cubic inch $\left(\mathrm{in}^{3}\right)$ & 16.39 & milliliter (mL) \\
\hline cubic inch $\left(\mathrm{in}^{3}\right)$ & 0.01639 & liter (L) \\
\hline acre-foot (acre-ft) & 1,233 & cubic meter $\left(\mathrm{m}^{3}\right)$ \\
\hline acre-foot (acre-ft) & 0.001233 & cubic hectometer $\left(\mathrm{hm}^{3}\right)$ \\
\hline \multicolumn{3}{|c|}{ Flow rate } \\
\hline acre-foot per year (acre-ft/yr) & 1,233 & cubic meter per year $\left(\mathrm{m}^{3} / \mathrm{yr}\right)$ \\
\hline acre-foot per year (acre-ft/yr) & 0.001233 & cubic hectometer per year $\left(\mathrm{hm}^{3} / \mathrm{yr}\right)$ \\
\hline gallon per minute (gal/min) & 0.06309 & liter per second $(\mathrm{L} / \mathrm{s})$ \\
\hline inch per year (in/yr) & 25.4 & millimeter per year $(\mathrm{mm} / \mathrm{yr})$ \\
\hline \multicolumn{3}{|c|}{ Mass } \\
\hline pound, avoirdupois (lb) & 0.4536 & kilogram $(\mathrm{kg})$ \\
\hline \multicolumn{3}{|c|}{ Density } \\
\hline pound per cubic foot $\left(\mathrm{lb} / \mathrm{ft}^{3}\right)$ & 0.01602 & gram per cubic centimeter $\left(\mathrm{g} / \mathrm{cm}^{3}\right)$ \\
\hline \multicolumn{3}{|c|}{ Radioactivity } \\
\hline picocurie per liter $(\mathrm{pCi} / \mathrm{L})$ & 0.037 & becquerel per liter $(\mathrm{Bq} / \mathrm{L})$ \\
\hline
\end{tabular}

Temperature in degrees Fahrenheit $\left({ }^{\circ} \mathrm{F}\right)$ may be converted to degrees Celsius $\left({ }^{\circ} \mathrm{C}\right)$ as follows:

$$
{ }^{\circ} \mathrm{C}=\left({ }^{\circ} \mathrm{F}-32\right) / 1.8
$$

Vertical coordinate information is referenced to the National Geodetic Vertical Datum of 1929 (NGVD 29).

Horizontal coordinate information is referenced to the North American Datum of 1927 (NAD 27).

Altitude, as used in this report, refers to distance above the vertical datum.

Concentrations of chemical constituents in water are given either in milligrams per liter (mg/L) or micrograms per liter $(\mu \mathrm{g} / \mathrm{L})$.

\section{ABBREVIATED GEOPHYSICAL TERMS}

Milligal (mGal) is defined as $10^{-3}$ centimeter per second squared and is equal to $3.281 \times 10$ ${ }^{5}$ feet per second squared. Gram per cubic centimeter is a measure of density. Ohm is the International System unit of electrical resistance equal to that of a conductor in which a current of one ampere is produced by a potential of one volt across its terminals. Ohm-meter is a unit of resistivity and is the resistance of a meter cube to the flow of current between opposite faces. 


\section{Well-Naming System}

WELL (C-18-23)32abc
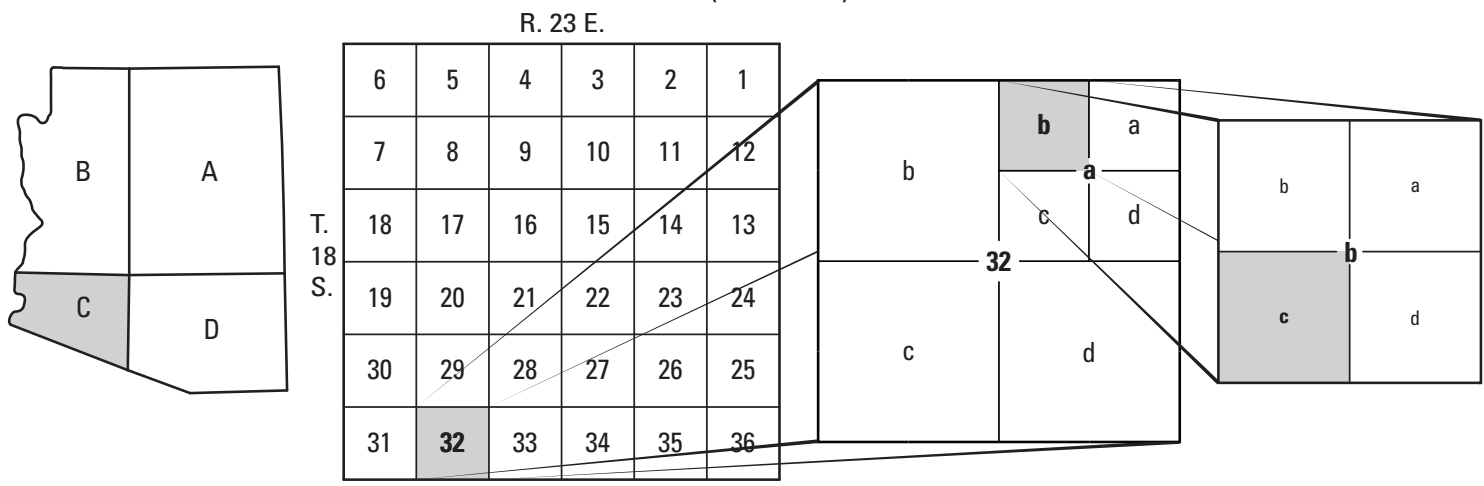

Quadrant C, Township 18 South, Range 23 East, section 32, quarter section $a$, quarter section $b$, quarter section $c$

The well numbers used by the U.S. Geological Survey in Arizona are in accordance with the Bureau of Land Management's system of land subdivision. The land survey in Arizona is based on the Gila and Salt River meridian and base line, which divide the State into four quadrants and are designated by capital letters A, B, C, and D in a counterclockwise direction beginning in the northeast quarter. The first digit of a well number indicates the township, the second the range, and the third the section in which the well is situated. The lowercase letters $a, b, c$, and $d$ after the section number indicate the well location within the section. The first letter denotes a particular 160-acre tract, the second the 40 -acre tract, and the third the 10 -acre tract. These letters also are assigned in a counterclockwise direction beginning in the northeast quarter. If the location is know within the 10 -acre tract, consecutive numbers beginning with 1 are added as suffixes. In the example shown, well number (C-18-23)32abc designates the well as being in the SW1/4, NW1/4, NE1/4, section 32, Township 18 South, and Range 23 East. 
This page left blank intentionally. 


\title{
Hydrogeologic Framework Refinement, Ground-Water Flow and Storage, Water-Chemistry Analyses, and Water-Budget Components of the Yuma Area, Southwestern Arizona and Southeastern California
}

\author{
By Jesse E. Dickinson, Michael Land, Claudia C. Faunt, S.A. Leake, Eric G. Reichard, John B. Fleming, \\ and D.R. Pool
}

\section{Abstract}

The ground-water and surface-water system in the Yuma area in southwestern Arizona and southeastern California is managed intensely to meet water-delivery requirements of customers in the United States, to manage high ground-water levels in the valleys, and to maintain treaty-mandated waterquality and quantity requirements of Mexico. The following components in this report, which were identified to be useful in the development of a ground-water management model, are: (1) refinement of the hydrogeologic framework; (2) updated water-level maps, general ground-water flow patterns, and an estimate of the amount of ground water stored in the mound under Yuma Mesa; (3) review and documentation of the ground-water budget calculated by the Bureau of Reclamation, U.S. Department of the Interior (Reclamation); and (4) waterchemistry characterization to identify the spatial distribution of water quality, information on sources and ages of ground water, and information about the productive-interval depths of the aquifer.

A refined three-dimensional digital hydrogeologic framework model includes the following hydrogeologic units from bottom to top: (1) the effective hydrologic basement of the basin aquifer, which includes the Pliocene Bouse Formation, Tertiary volcanic and sedimentary rocks, and preTertiary metamorphic and plutonic rocks; (2) undifferentiated lower units to represent the Pliocene transition zone and wedge zone; (3) coarse-gravel unit; (4) lower, middle, and upper basin fill to represent the upper, fine-grained zone between the top of the coarse-gravel unit and the land surface; and (5) clay A and clay B. Data for the refined model includes digital elevation models, borehole lithology data, geophysical data, and structural data to represent the geometry of the hydrogeologic units. The top surface of the coarse-gravel unit, defined by using borehole and geophysical data, varies similarly to terraces resulting from the down cutting of the
Colorado River. Clay A is nearly the same as the previous conceptual hydrogeologic model definition (Olmsted and others, 1973), except for a minor westward extension from the city of Yuma. Clay B is extended to the southerly international boundary and increased in areal extent by about two-thirds of the original extent (Olmsted and others, 1973). The other hydrogeologic units generally are the same as in the previous conceptual hydrogeologic model.

Before development, the Colorado and Gila Rivers were the sources of nearly all the ground water in the Yuma area through direct infiltration of water from river channels and annual overbank flooding. After construction of upstream reservoirs and clearing and irrigation of the floodplains, the rivers now act as drains for the ground water. Ground-water levels in most of the Yuma area are higher now than they were in predevelopment time. A general gradient of ground-water flow toward the natural discharge area south of the Yuma area still exists, but many other changes in flow are evident. Ground water in Yuma Valley once flowed away from the Colorado River, but now has a component of flow towards the river and Mexicali Valley. A ground-water mound has formed under Yuma Mesa from long-term surface-water irrigation; about 600,000 to 800,000 acre-ft of water are stored in the mound. Ground-water withdrawals adjacent to the southerly international boundary have resulted in water-level declines in that area.

The reviewed and documented water budget includes the following components: (1) recharge in irrigated areas, (2) evapotranspiration by irrigated crops and phreatophytes, (3) ground-water return flow to the Colorado River, and (4) ground-water withdrawals (including those in Mexicali Valley). Recharge components were calculated by subtracting the amount of water used by crops from the amount of water delivered. Evapotranspiration rates were calculated on the basis of established methods, thus were appropriate for input to the ground-water flow model developed by the Bureau of Reclamation (William Greer, hydrologist, Bureau of 
Reclamation, written commun., 2005). Evapotranspiration by crops and phreatophytes were calculated by using crop coefficient methods and meteorological data. Other methods of calculating evapotranspiration rates by using combinations of satellite imagery and ground-based data could be used for higher spatial and temporal resolution. Ground-water return flow during years of low flow on the Colorado River (1972-82, 1987-92, and 1994-96) averaged 79,000 acre-ft per year. Ground-water withdrawal data for 1970-99 were similar to other estimates made by the U.S. Geological Survey for the Yuma area.

New water-chemistry data were collected in 12 wells and 8 canals/drains to characterize spatial patterns in chemical constituents, determine isotopic ages of water, infer possible sources of ground water, and locate the vertical intervals of the aquifer that contribute most water to wells. Depth-dependent samples were collected at one of the wells (YM-10). A large quantity of water-quality data were compiled from Bureau of Reclamation and U.S. Geological Survey records and merged into the U.S. Geological Survey National Water Information System database. New samples were analyzed for major ions, nutrients, stable isotopes of oxygen and hydrogen, tritium $\left({ }^{3} \mathrm{H}\right)$, and carbon-14 $\left({ }^{14} \mathrm{C}\right)$ (along with $\mathrm{C}^{13} / \mathrm{C}^{12}$ ratios). Light values of oxygen-18 $\left({ }^{18} \mathrm{O}\right)$ and deuterium $\left({ }^{2} \mathrm{H}, \mathrm{D}\right)$ in well 242-2 indicate recharge from the Colorado River. Heavy water samples from wells 242-22, CADC, and Mesa del Sol indicate local recharge sources. Tritium data indicate there is young water in wells in the valleys and near the edge of Yuma Mesa, while older water is found far from the Colorado River. ${ }^{14} \mathrm{C}$ data indicate that water from wells near the southerly international boundary is at least several thousand years old.

\section{Introduction}

The complex surface- and ground-water system in the Yuma area is managed intensely for irrigated agriculture as well as for domestic, municipal, and industrial uses (fig. 1). Water is supplied directly from the Colorado River by diversion canals and river pumps. As part of its responsibilities, the Yuma Area Office (YAO) of the Bureau of Reclamation (Reclamation), U.S. Department of the Interior, faces the multiple challenges of meeting water-delivery requirements to U.S. customers, of meeting treaty-mandated water quality and quantity requirements for deliveries to Mexico, attaining and maintaining acceptable ground-water levels in Yuma Valley and South Gila Valley, and providing adequate return flows to the Colorado River above the northerly international boundary (NIB). Areas of particular concern for water management are zones of high water table in Yuma, South Gila, and North Gila Valleys, and accumulated ground water under Yuma Mesa.

Many of the floodplains of the Colorado and Gila Rivers are irrigated with water from the Colorado River. Application of water to the land surface causes high water tables in parts of Yuma, South Gila, and North Gila Valleys, and drainage by wells and ditches is required to maintain the water-table altitude at acceptable levels.
Reclamation recognized that a ground-water management model would be a valuable tool to manage water resources. Reclamation asked the U.S. Geological Survey (USGS) to help in the development of a ground-water management model.

In response to this request, the USGS, in cooperation with Reclamation, has identified three phases of work to provide science support to the YAO for the management of the complex surface-water/ground-water system:

Phase 1. Refinement of the understanding of the hydrogeologic framework and regional water chemistry of the Yuma area;

Phase 2. Evaluation and refinement of a ground-water flow model developed by Reclamation; and

Phase 3. Development of an optimization model to evaluate management strategies for the surface-water/groundwater system.

This report presents the results for Phase 1. The expanded objectives of this phase are to:

1. Improve the understanding of the hydrogeologic framework and water chemistry of the Yuma area in terms of the relations between the geologic units, hydrologic properties, and chemical properties;

2. Identify relations between hydrogeologic conditions and water management concerns; and

3. Incorporate new findings in order to refine and update the ground-water flow model that will be used for wateruse decisions and the development of a ground-water management tool.

\section{Purpose and Scope}

This report presents a synthesis of new and existing hydrogeologic and geochemical data of the Yuma area in southwestern Arizona and southeastern California by the USGS, in cooperation with Reclamation. This report focuses on a refinement of the hydrogeologic framework in critical areas within the study area where an enhanced understanding of the ground-water system is most important for improving management tools. The scope of the study includes (1) an evaluation of existing hydrogeologic and geochemical data provided by Reclamation, (2) interpretation of new targeted surface geophysical surveys and regional gravity data, (3) targeted water-quality sampling, (4) review and documentation of ground-water budget components calculated by Reclamation, (5) analysis of current ground-water levels and flow directions, and (6) a focused evaluation of the hydrogeologic framework previously developed by Olmsted and others (1973). Areas of focus include parts of Yuma and South Gila Valleys where high water levels are present and the ground-water mound under Yuma Mesa, termed "the Yuma mound," where there is an interest in future development of water resources. 


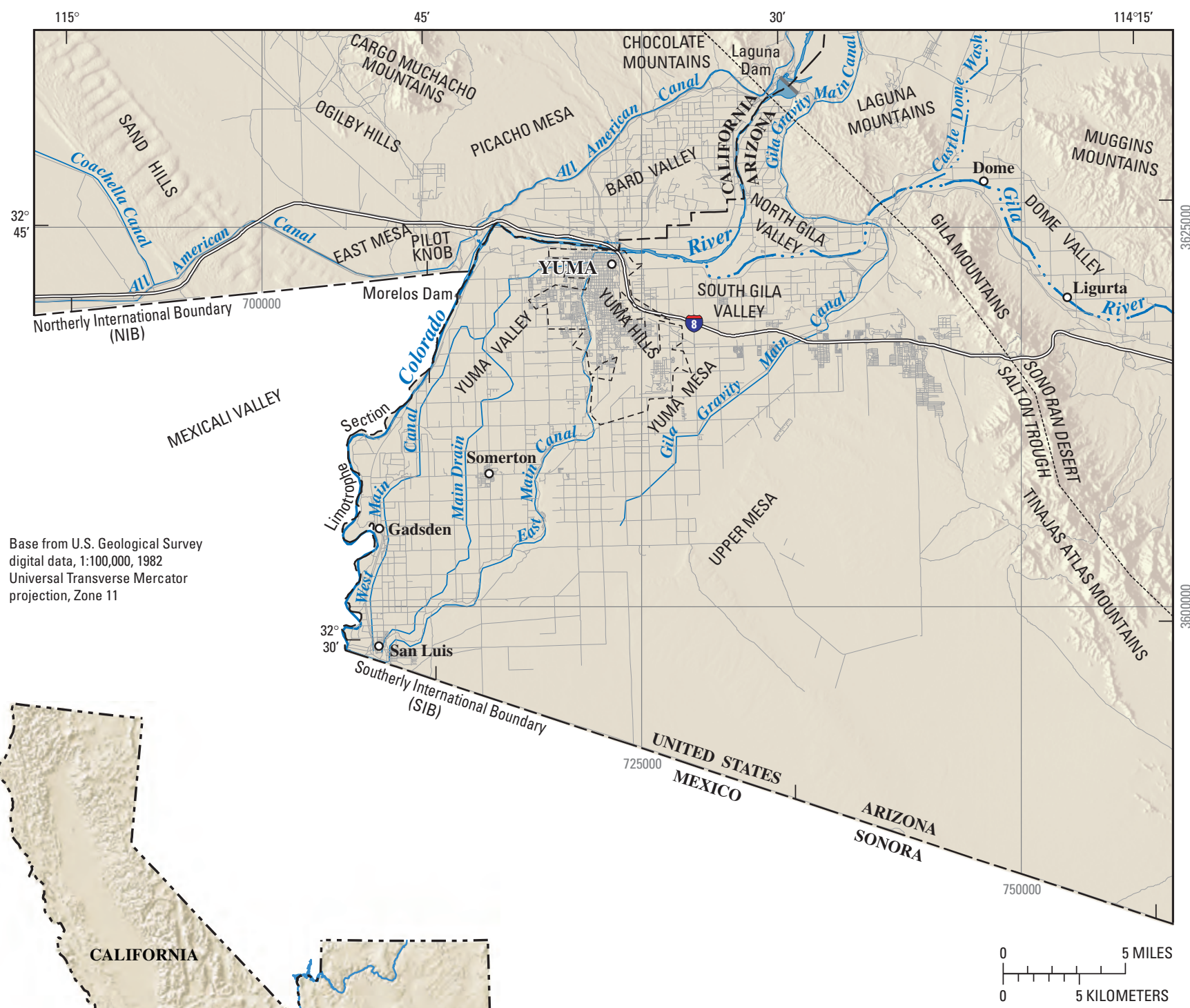

Figure 1. Yuma area in southwestern Arizona and southeastern California. 
This report defines and describes the geographic setting that is termed "the Yuma area" and provides brief background information about the geology, climate, and previous investigations concerning ground-water management issues in the area. Descriptions of the hydrogeologic framework for these areas include a review of the general characteristics of the units within the aquifer from previous reports, a summary of existing well logs and geophysical logs, and a new threedimensional (3D) digital hydrogeologic framework model (HFM) of the aquifer system that describes the spatial extent and thicknesses of sediment layers that govern ground-water flow. Data from the HFM can be included in the refinement of an existing ground-water flow model (William Greer, hydrologist, Bureau of Reclamation, written commun., 2005), identified for future Phase 2 study. Descriptions of the groundwater conditions include a summary of available ground-water level data in previous reports and in Reclamation and USGS archives, ground-water level maps for average conditions in 2004-2005, and generalized ground-water flow directions. Discussion of the water chemistry includes a summary of existing water chemistry data from Reclamation and USGS archives, description of new data collected for this study, and results from analyses of these new data. A review of the overall water budget calculated by Reclamation for a groundwater flow model describes methods of calculating budget components. For this study, the Yuma area is limited mainly to the United States, except for components of the water budget for Mexicali Valley, Mexico, which is connected hydraulically to the ground-water system of the Yuma area.

\section{Previous Investigations}

Decades of study of the hydrology of the Yuma area have been done to remedy drainage problems owing to high groundwater levels in Yuma and South Gila Valleys. Sweet (1952) calculated consumptive use, ground-water return flow to the Colorado River, overall water budgets, and the volume of flow from Yuma Mesa to Yuma Valley. Brown and others (1956) evaluated Sweet's (1952) conclusions about ground-water flow from Yuma Mesa to Yuma and South Gila Valleys. They analyzed hydrologic data in conjunction with the regional hydrogeology and determined that highly permeable coarse gravels underlying less-permeable sand and silt significantly influence the occurrence and movement of ground water. Tipton and Kalmbach, Inc. and Jacob (1956) used data from Brown and others (1956) to calculate ground-water flow from the mound under Yuma Mesa to Yuma Valley. Jacob (1960) analyzed aquifer tests to estimate the transmissivity and storage properties of the aquifer system, and used electrical analog models to simulate ground-water responses to drainage wells in Yuma Valley and to improve understanding of the flow characteristics of the mound under Yuma Mesa.

During the 1960s and 1970s, the USGS performed comprehensive studies of the Yuma area that provide much of the basis of current understanding of the local hydrogeology. Olmsted and others (1973) included detailed descriptions and results of investigations of the regional physiography, water use, geomorphology, subsurface geology and structures, ground-water and surface-water conditions, water budgets, and an electrical analog ground-water flow model. Mattick and others (1973) described results of geophysical surveys performed in support of the comprehensive study by Olmsted and others (1973). In particular, the surveys were done to investigate the regional geology and the distribution and thickness of Cenozoic deposits that constitute most of the aquifer. The geophysical methods included gravity, aeromagnetic, seismic-refraction, and resistivity surveys. Patten (1977) developed a transient electrical analog groundwater flow model to estimate the amount of southwesterly ground-water flow across the limotrophe section into Mexicali Valley. The model was constructed primarily on the basis of the hydrogeology presented by Olmsted and others (1973). Simulation results indicated an increase of ground-water flow across the limotrophe section owing to withdrawals in Mexicali Valley. Flow also increased across the southerly international boundary (SIB) because of large hydraulic gradients between the ground-water mound under Yuma Mesa and the water table near the SIB.

This study enhances the knowledge gained from previous studies, particularly Olmsted and others (1973), by using new methods that allowed revisions of previous interpretations to analyze additional data. Much of the geologic data and interpretations from Olmsted and others (1973) serve as the basis for the HFM and interpretations in this report. Major rock types were classified into major geologic and hydrogeologic units (HGUs) used to organize geologic information in this report. Specific data used from Olmsted and others (1973) are the altitude and spatial extent of hydrologic units. Changes to the ground-water system for 2004-05 conditions are measured by comparison to historical ground-water conditions in Olmsted and others (1973). The information contained in this report is intended to be used as the basis for the evaluation and refinement of the existing ground-water flow model (Phase 2) and the development of a surface-water/ground-water optimization (management) model (Phase 3).

\section{Acknowledgments}

Michael Vandevelde, William Greer, Earl Burnett, and Fred Croxen of the Bureau of Reclamation provided crucial information and data. Michael facilitated all aspects of data transfer, including modifications of a water-chemistry database for improved access. William provided guidance on regional hydrology and assembled data sets needed to evaluate the water-budget components. Earl provided insight on geology and data sets needed to construct the HFM. Fred assembled much needed data for mapping ground-water levels. Kurt Schonauer of the USGS digitized geologic data for constructing the HFM. The University of Arizona, Department of Geological Engineering, Geophysics Field Camp class of 2005 collected data used to identify shallow geologic structures. 


\section{Description of the Yuma area}

\section{Physiography}

The Yuma area is within the Basin and Range physiographic province of the southwestern United States along the international boundary with Mexico and is within southwestern Arizona and southeastern California (fig. 1). The Arizona portion of the Basin and Range physiographic province is characterized by mountain ranges that typically trend to the north-northwest, and low-lying basins that are filled by sediment from the weathered and eroded mountain ranges. The northeastern part of the study area is within the Sonoran Desert Section of the Basin and Range Province, but according to Fenneman's classification (1931, 1946), most of the study area is within the Salton Trough Section. The Yuma area extends 30 miles from Laguna Dam southward to the SIB, and 55 miles from the Gila Mountains westward to Coachella Canal diversion from the All-American Canal (fig. 1).

The Yuma area consists of a low, generally flat basin filled by sediment from nearby sources and by deltaic deposits from the Colorado River surrounded by rugged crystalline and volcanic mountains. The Yuma area contains the southernmost length of the Colorado River before it flows south into Mexico. The Gila River flows westward until it joins the Colorado River east of the city of Yuma.

The basin can be divided on the basis of topography into areas of dissected and undissected piedmont slopes, river terraces and mesas, valleys, and crystalline bedrock mountains (fig. 1). Extensive descriptions of these landforms and areas are presented in Olmsted and others (1973). The area informally designated the "Upper Mesa" generally consists of sand dunes adjacent to dissected pediment slopes along the western margin of the Gila Mountains. Yuma Mesa is topographically lower than the Upper Mesa. Yuma Mesa is a river terrace and former valley and delta plain of the Colorado and Gila Rivers (Olmsted and others, 1973). Yuma Mesa generally is flat and typically lies $50-80 \mathrm{ft}$ above the valleys. Current flood plains are narrower than older valleys because the river downcut and eroded the older flood plain that is now Yuma Mesa. The floodplains, from north to south, are North Gila Valley, the area informally called "Bard Valley", South Gila Valley, and Yuma Valley. The flood-plain altitude decreases from $150 \mathrm{ft}$ in North Gila Valley below Laguna Dam where the Colorado River enters the Yuma area to $85 \mathrm{ft}$ in Yuma Valley where it passes the SIB. Altitudes of mountains in the area are 2,700-3,150 ft along the Gila Mountains, 1,080 $\mathrm{ft}$ within the Laguna Mountains, 1,500 ft within the Chocolate Mountains, and 2,100-2,200 ft along the Cargo Muchacho Mountains (Olmsted and others, 1973).

\section{Climate}

The Yuma area is one of the driest desert regions in the United States. Although summer temperatures are hot, the mild winter temperatures and abundant sunshine are attractive to the growing population in the Yuma area. During July, the average maximum temperature is $107.0^{\circ} \mathrm{F}$, and the average minimum temperature is $80.4^{\circ} \mathrm{F}$. During January, the average maximum temperature is $68.5^{\circ} \mathrm{F}$, and the average minimum temperature is $44.1^{\circ} \mathrm{F}$. An annual average of 179 days from 1948 to 1996 had a daily high temperature greater than or equal to $90^{\circ} \mathrm{F}$. The average annual precipitation at the National Oceanic and Atmospheric Administration station Yuma Weather Service Office Airport (029660) near the city of Yuma was 2.96 in. from 1948 to 2005 (Western Region Climate Center, accessed 2005). Precipitation is greatest in summer and winter. Precipitation averages 1.0 in. during July through September and 1.08 in. during December through February. Precipitation during the spring and fall averages 0.89 in.

\section{Geology}

The structural features of the Salton Trough and Sonoran Desert physiographic sections differ in pattern and time (Olmsted and others, 1973; fig. 2). The southwestern part of the Sonoran Desert within the eastern part of the Yuma area is characterized by subparallel, narrow (but rugged) mountain ranges, generally trending north-northwest, separated by extensive desert plains underlain by Cenozoic sedimentary fill; the ranges approximately assumed their present configuration by middle Tertiary time (Olmsted and others, 1973). The Salton Trough, by contrast, has been tectonically active to the present time and its faults tend somewhat more northwesterly than those in the Sonoran Desert. These faults are part of the San Andreas Fault system (west of the study area), a major crustal feature with aggregate-right slip in parts of southern California of as many as 160 miles since earliest Miocene time. The Salton Trough is an elongated tectonic depression and landward extension of the Gulf of California, (Mattick and others, 1973) that extends from near Palm Springs, California, to the head of the Gulf of California. The Salton Trough has sunk continuously during Cenozoic time-accumulating as much as $20,000 \mathrm{ft}$ of mostly non-marine fill, much of which consists of alluvial and deltaic deposits of the Colorado River (Biehler and others, 1964; fig. 3, table 1). The Colorado River delta is built across the trough, forming a dam that blocks the Gulf of California seawater from flowing north (Abbott, 1999).

Increased tectonic activity and the resulting marked increase in the rate of extension in Miocene time resulted in the initial formation of the Salton Trough as a major pullapart basin bounded by faults. The Gulf of California began forming in middle Miocene time, 14-13 million years ago, and originally was a long, relatively narrow rift basin that accumulated sediments from eroded uplifted pre-Tertiary igneous and metamorphic rocks and some ocean water flooding. From 13-5.5 million years ago, Baja California and southern California were part of the North American tectonic plate. The Gulf of California began opening 5.5 million years ago as a result of sea-floor spreading (Abbott, 1999). 


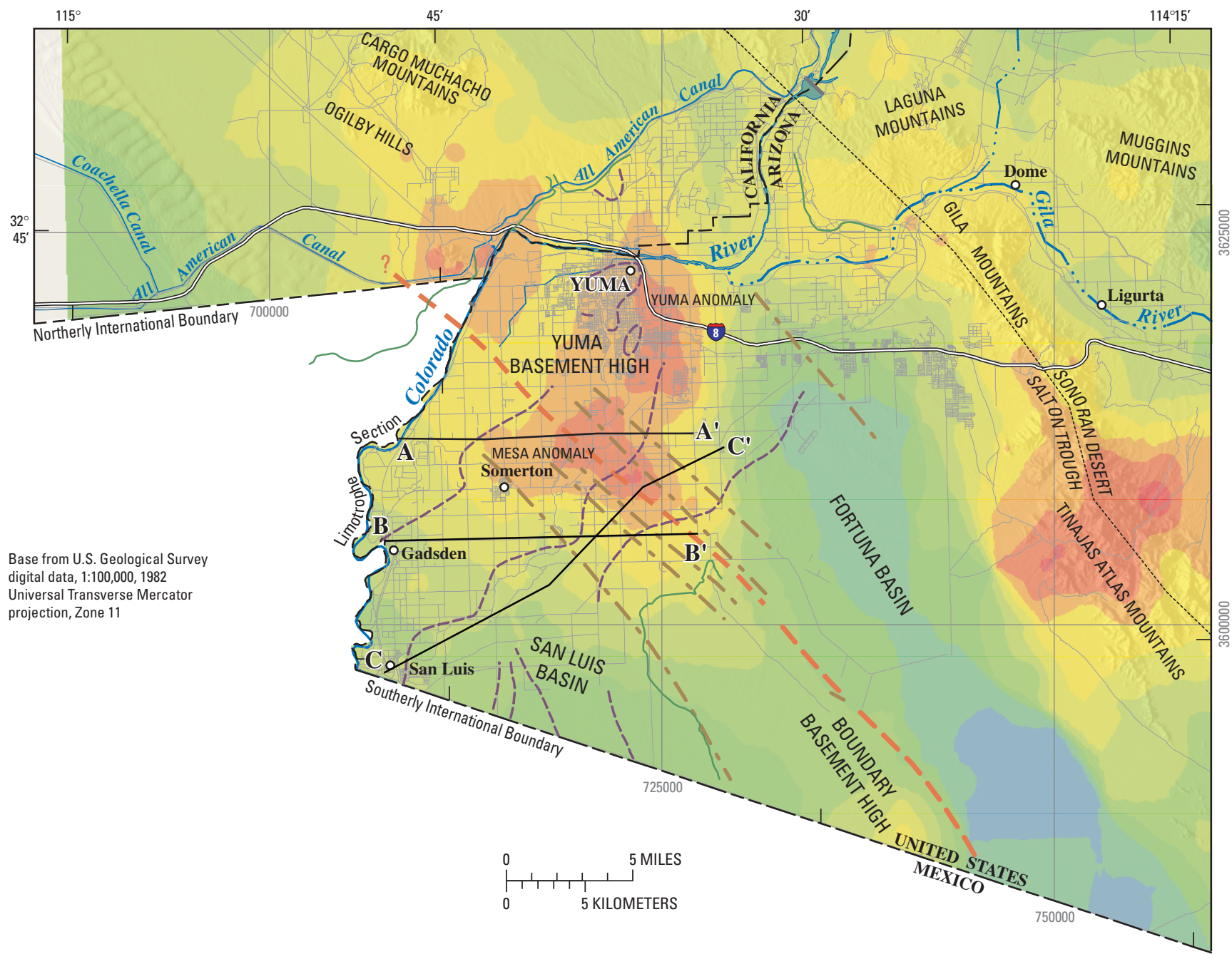

\section{EXPLANATION}
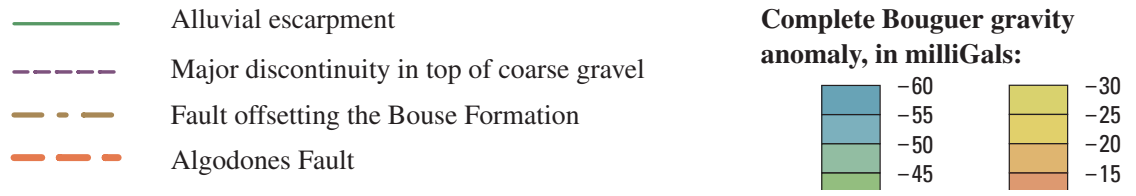

Figure 2. Structures that can affect ground-water flow and traces of geologic sections shown in figures 3, 10, 11, and 12. 

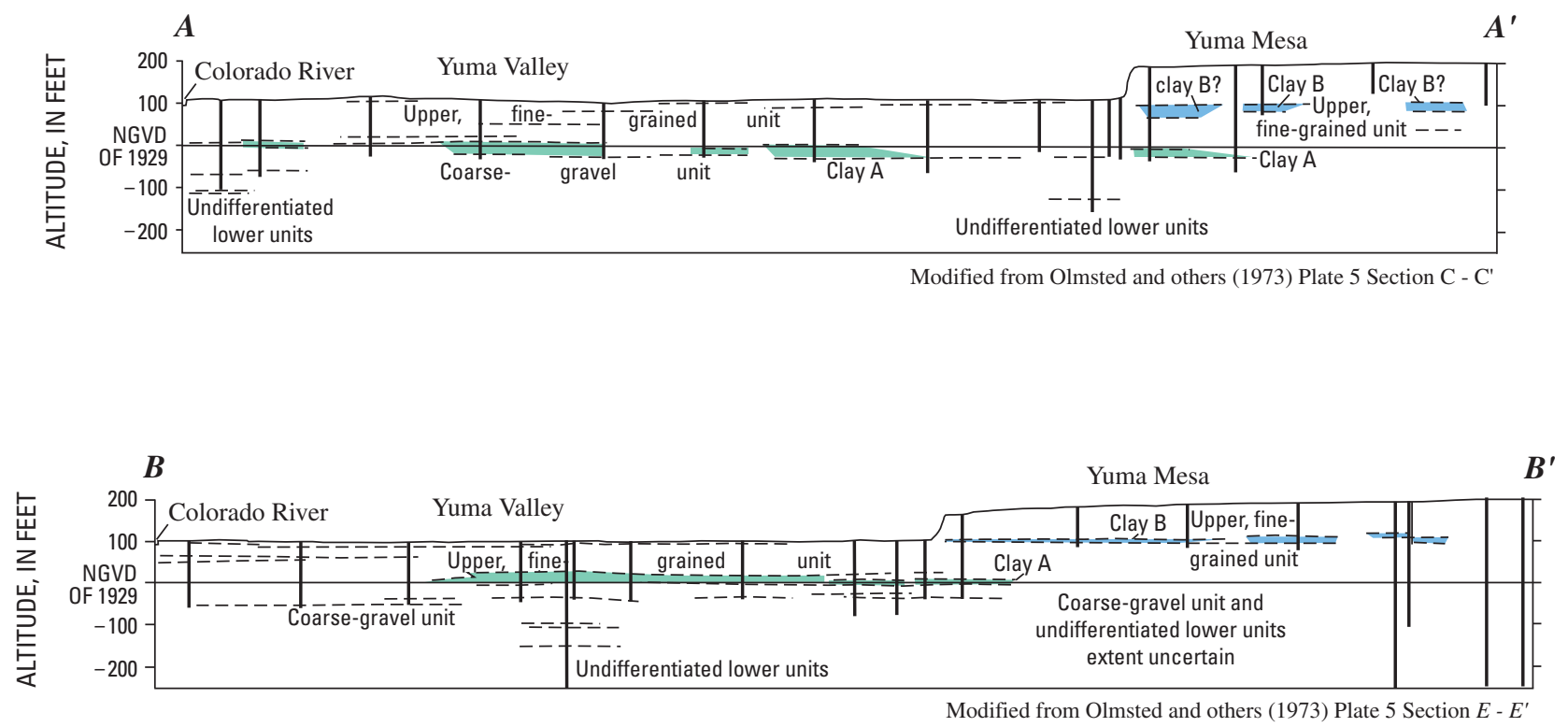

\section{EXPLANATION}

$\begin{array}{ll}\text { Clay } \bar{A}- & \text { Hydrogeologic unit from } \\ \text { Claysted and others (1973, plate 5) }\end{array}$

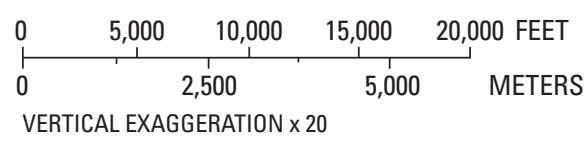

Well having geophysical log from

Olmsted and others (1973, plate 5)

Figure 3. Cross sections showing hydrogeologic units in Yuma Valley and Yuma Mesa modified from Olmsted and others (1973, pl. 5). The top panel, showing section $A-A^{\prime}$, is modified from section $C-C^{\prime}$ from Olmsted and others $(1973$, pl. 5). The bottom panel, showing section $B-B^{\prime}$, is modified from section $E-E^{\prime}$ from Olmsted and others $(1973$, pl. 5). 
Table 1. Predominant stratigraphic units for each hydrogeologic unit, modified from Olmsted and others (1973).

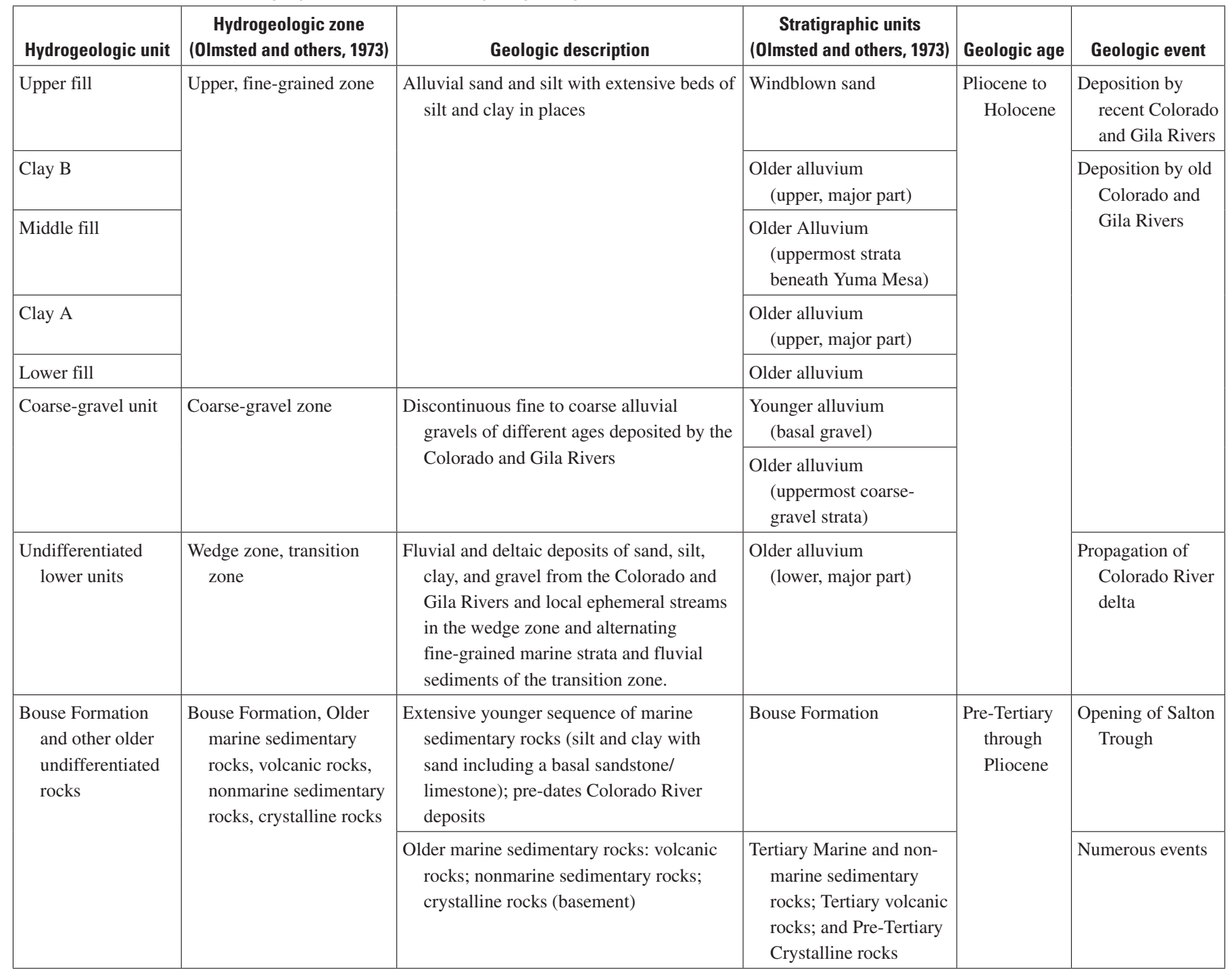

Sea-floor spreading separated Baja California and southern California from mainland Mexico and moved this landmass toward the northwest. About 5.2 million years ago, the Colorado River began dumping its massive load of sediments, overwhelming and burying most of the varied and complex local features. The Colorado River delta continued to develop as Baja California and southern California drifted to the northwest (Abbott, 1999).

In early Pliocene time, the ancient Colorado River delta expanded from the vicinity of present-day Yuma, effectively damming the northern Gulf of California from the topographically lower basin of the Salton Trough. During Pliocene-Pleistocene time, this area was a lush, well-watered plain with abundant rainfall. Shifting climatic patterns and Late Pleistocene to Holocene mountain building resulted in the present desert environment. As the land was uplifted, drainage patterns changed, and rainfall was modified by the imposition of high land to the west, preventing water-laden clouds from reaching the interior (Clifford and others, 1997). As the sea retreated during Pliocene time, boulders, cobbles, and gravels that had eroded from the adjacent mountains were deposited as an uninterrupted sequence of non-marine Pliocene-Pleistocene delta, lake bed, alluvial fan, and flood plain sediments. This deposition continued for about 4 million years. Coarse-grained gravels and conglomerates grade basinward into a sequence of terrestrial and lacustrine sandstone, siltstone, clays, and mudstones. Pleistocene lakes formed, resulting in deposition of clays (Clifford and others, 1997).

Several times during the last 2 million years, large freshwater lakes were present in the Salton Trough when the Colorado River deposited excess silt near its mouth into the Gulf of California. These temporary natural dams forced the river to flow northwesterly into the Salton Trough. Subsequent breaches of the silt dam would return the river 
to its southbound channel to the sea. The last of these lakes disappeared in approximately 1500. The current Salton Sea, the most recent manifestation of a lake in this area, was formed in 1905-07 by heavy Colorado River flooding and inadequate irrigation headgates below Yuma (Clifford and others, 1997). The geologic processes that formed the present landscape continue.

\section{Structural Features}

The Algodones Fault, thought to be associated with the San Andreas Fault system (Olmsted and others, 1973), crosses the Yuma area (fig. 2). This fault is identified by gravity and seismic-reflection surveys and by topographic anomalies where the land surface southwest of the fault is 30-60 ft higher than the surface to the northeast (Olmsted and others, 1973). Lineaments indicated by seismic-reflection data (Mattick and others, 1973) suggest that the fault has a branching pattern in the central part of the Upper Mesa that offsets the Bouse Formation (Olmsted and others, 1973).

Variations in the thickness of low density alluvial sediments can be mapped by using gravity methods. Spatial variations in the acceleration of gravity measured at the surface of the Earth are caused by variations in the density and thickness of subsurface materials. Low values of gravitational acceleration occur where low density alluvial sediments underlie the surface. High values of gravitational acceleration occur where high density crystalline and metamorphic rock crop out or are shallowly buried beneath alluvium. Gravity maps typically display values of complete Bouguer gravity anomaly, which is the difference between the observed gravity value and the gravity value for a theoretical Earth with a uniform density of $2.67 \mathrm{~g} / \mathrm{cm}^{3}$.

The regional complete Bouguer gravity anomaly in the Yuma area displays a strong and well defined gravity low that is associated with thick alluvial deposits (fig. 2). In addition, a strong and well-defined gravity high near Yuma Mesa is associated with outcrops of crystalline rocks and exceptionally strong horizontal gravity gradients are associated with the Algodones Fault. These well-defined gravity anomalies can be used to define the subsurface structure of the regional aquifer.

Areas of shallow bedrock on Yuma Mesa informally called the "Yuma basement high" (fig. 2) are indicated by gravity and magnetic surveys (Mattick and others, 1973). Gravity and magnetic data indicate two main features of the Yuma basement high: the northern Yuma anomaly which has three peaks of exposed bedrock near the city of Yuma, and the southern high referred to as the Mesa anomaly (fig. 2). No exposures are related to the Mesa anomaly, but granitic rocks at a depth of $47 \mathrm{ft}$ below land surface are indicated in well logs. Another anomaly called the "boundary basement high" (fig. 2) is centered on granitic outcrops along the SIB (Mattick and others, 1973). These anomalies, outcrops of granitic rocks, and well-log data suggest that a buried basement ridge is underlying the western part of Yuma Mesa (Mattick and others, 1973). The ridge has a north-northwest trend that is similar to other fault-block ranges, such as the Gila Mountains, and well logs indicate steep margins comparable to other exposed ranges (Mattick and others, 1973). The low gravity anomaly referred to as the "Fortuna Basin" (fig. 2), interpreted as a deep basin between the Gila Mountains and the buried ridge associated with the Yuma basement high, extends south-southeast from Interstate Highway 8 to the SIB and likely into Mexico. The area referred to as the "San Luis Basin", in the southwestern part of the Yuma area (fig. 2), represents a deep basin that is bound on the northwest by the buried ridge associated with the Yuma basement high and the boundary basement high (Mattick and others, 1973).

\section{Hydrogeology}

Using previous descriptions and conceptual models of the hydrogeology of the Yuma area and new data (particularly water chemistry) collected by the USGS, a revised conceptual model of the hydrogeology and movement of ground water has been constructed. A 3D digital HFM has been constructed on the basis of the revised conceptual model by using HGUs and geologic structures. HGUs are laterally extensive rocks and deposits that have distinct hydrologic properties owing to their lithologic, stratigraphic, and structural characteristics. The HFM can be used to visualize the extent of HGUs and structural features and can be incorporated into future hydrogeologic studies.

\section{Description of Hydrogeologic Units}

Olmsted and others (1973) grouped the Yuma area's water-bearing deposits into two divisions on the basis of age (table 1): water-bearing rocks of Tertiary age, and waterbearing deposits of Pliocene to Holocene age. In comparison to the younger deposits of the second group, rocks of the first group generally do not yield significant quantities of water owing to their relatively poor transmissive properties (Olmsted and others, 1973). This report describes the spatial and vertical distribution and general structures of the more transmissive younger deposits.

The HGUs defined in this report are similar to those described in great detail by Olmsted and others (1973). Stratigraphic units were grouped into hydrogeologic zones by Olmsted and others (1973) on the basis of lithologic and water-bearing characteristics. The poorly water-bearing stratigraphic units of Tertiary age, described by Olmsted and others (1973), discussed in this report are the Bouse Formation (Pliocene), and the transition zone (Pliocene). The waterbearing stratigraphic units of Pliocene to Holocene age are the older alluvium, the younger alluvium, and the windblown sand (Olmsted and others, 1973; table 1). 
Minor modifications in the HGU definitions were helpful for constructing the HFM. In this report, the waterbearing units are divided into the undifferentiated lower units, coarse-gravel unit, lower fill, clay A, middle fill, clay B, and upper fill. The relations between the stratigraphic units, hydrogeologic zones named by Olmsted and others (1973), and the HGUs in this report are shown in table 1.

This report principally describes the spatial extent and altitude of the coarse-gravel unit, clay A, and clay B. Stratigraphic units that underlie the coarse-gravel unit but overlie the Bouse Formation are grouped as undifferentiated lower units. These units are discussed from oldest to youngest in the subsequent subsections.

\section{Bouse Formation and Older Undifferentiated Rocks}

The HGU Bouse Formation and older undifferentiated rocks represent the nonmarine sedimentary rocks (Tertiary), older marine sedimentary rocks (Tertiary), and the Bouse Formation (Pliocene) of Olmsted and others (1973).

While these units were not a focus of this study, the HGU is included because the top of the Bouse Formation often is considered the effective hydrologic basement of the basin aquifer owing to the abundance of impermeable sediments (Olmsted and others, 1973). The Bouse Formation consists of Pliocene rocks deposited by a marine embayment after the current mountains reached the present configurations. The unit contains mainly silt and clay containing thin interbeds of fine sand, hard calcareous claystone and, in basal sections, limy sandstone or sandy limestone, tuff, and local conglomerates. The Bouse Formation generally occurs throughout the subsurface of the Yuma area and has a small surface exposure near Imperial Dam (Mattick and others, 1973). The extent of the Bouse Formation was inferred by Olmsted and others (1973, fig. 15) from the few wells that penetrate the top of the formation, which is greater than $1,000 \mathrm{ft}$ in depth in most of the area. The unit is found in parts of the Colorado River Valley north the Yuma area. The thickness varies from $0 \mathrm{ft}$ to about 1,000 $\mathrm{ft}$ in the southwestern part of the Yuma area (Olmsted and others, 1973).

\section{Undifferentiated Lower Units}

The undifferentiated lower units represent the transition zone and the wedge zone of Olmsted and others (1973) that are lower than the coarse-gravel unit. The transition zone represents episodic deposition by encroaching marine embayments or by the Colorado and Gila Rivers. The bottom of the unit is indicated by the lowest evidence of fluvial sediments just above the fine-grained marine beds of the Bouse Formation, and the top of the unit is defined by the highest strata having fossiliferous marine clay or silt (Olmsted and others, 1973). The thickness is about several hundred feet near the southwestern part of the Yuma area, as indicated by lithology and geophysical data from wells (Olmsted and others, 1973), although the general structure of this unit is not well described by Olmsted and others (1973), owing to the few wells that penetrate this unit.

The wedge zone, which underlies the river valleys and Yuma Mesa (Olmsted and others, 1973), contains most of the water-bearing units of the Pliocene to Holocene deposits, by volume. The unit is generally thickest in the San Luis Basin and "wedges out" (reduces in thickness) beneath the coarse-gravel unit near the Laguna and Gila Mountains to the northeast. The wedge zone chiefly is older alluvium (Pliocene and Pleistocene). The older alluvium comprises fluvial and deltaic deposits of sand, silt, clay, and gravel from the Colorado and Gila Rivers and local ephemeral streams. Deposition of the undifferentiated lower units occurred discontinuously with cycles of aggradation and degradation as the river meandered through the valleys and deposited material during regional downwarping and eroded during regional upwarping. Deposition and erosion also likely occurred due to sea-level fluctuations related to glacial cycles. In the northeastern parts of the area and near the mountain blocks, deposits likely were removed (eroded) during degradation. The wedge zone is thickest $(2,500 \mathrm{ft})$ at the San Luis Basin (fig. 2) and the northern part of Fortuna Basin (fig. 2) and thins toward the Gila and Laguna Mountains (fig. 1) to the northeast and toward the Yuma Hills (fig. 1) to the southeast. The altitude of the top surface of the unit is undefined when the top strata are coarse gravel, which would appear to be similar material to the overlying coarse-gravel unit. Thus, the top surface is vague and arbitrary in some areas as indicated by geologic sections in Olmsted and others (1973, pl. 5; fig. 3, this report).

\section{Coarse-Gravel Unit}

The coarse-gravel unit, which represents the coarsegravel zone from Olmsted and others (1973), comprises fine-to-coarse gravel beneath much of Yuma Valley and Yuma Mesa and is the main water-bearing strata in the Yuma area (Olmsted and others, 1973). Nearly all wells used for water extraction penetrate the coarse-gravel unit owing to its high transmissive properties. The coarse-gravel unit constitutes the top of the older alluvium unit (table 1), which predominantly comprises coarse gravel, and the basal-gravel portions of the Quaternary younger alluvium.

Deposition and downcutting events by the Colorado River have produced a series of terrace-like gravel strata that comprise the coarse-gravel unit. The coarse-gravel unit consists of discontinuous gravel bodies of differing age deposited by the Colorado and Gila Rivers (Olmsted and others, 1973). Analyses of borehole lithology data and resistivity logs suggest that the top of gravels within the same terrace extending from Yuma Valley to Yuma Mesa are continuous. The terraces represent the top of the depositional surface when the river valley was wider. The gravels grade into finer sediments within the upper, fine-grained zone, such as clay A and clay B, which suggest sequences of deposition trending from river alluvium to lower-energy flood plains and 
lakes. The current valleys were downcut into older sediments on Yuma Mesa within the upper, fine-grained zone that was deposited by the Colorado and Gila Rivers.

The unit generally slopes gently downward to the south and southwest along the direction of the present Colorado River, as indicated by wells penetrating the top of the coarsegravel unit (Olmsted and others, 1973, pl. 7). The top and bottom altitudes are highest along the eastern extent of the unit and become lower, in terrace-like fashion, toward the west. The top surface of the unit averages $100 \mathrm{ft}$ below the land surface within Yuma and South Gila Valleys, and 170-180 ft below land surface within Yuma Mesa. The depth to the top surface generally increases toward the southwest. The thickness ranges 0-150 ft (Olmsted and others, 1973). Resistivity logs show similar patterns within the gravel along sections from the Yuma Valley to under Yuma Mesa, which indicate that the gravels under Yuma Valley and the escarpment of the Upper Mesa are alluvial in origin and probably relate to meanderings of the ancestral Colorado River.

\section{Clay A}

The lower clay in the upper, fine-grained zone, designated "clay A" by Olmsted and others (1973), mainly underlies Yuma Valley and extends into the western edge of Yuma Mesa. Clay A is at the top part of the older alluvium and can be identified readily on electric logs by its low resistivity and on gamma logs by its relatively high natural gamma radiation (Olmsted and others, 1973). Most of the clayey strata in the upper, fine-grained zone contain a considerable amount of silt and sand. As a result, the clayey units do not cause extensive perching of ground water (Olmsted and others, 1973), but do inhibit vertical movement of ground water so that sizable differences in water levels exist at different depths. Clay A is not far above the coarse-gravel unit and ranges in thickness from a few inches to about $35 \mathrm{ft}$ (Olmsted and others, 1973). Parts of the clay appear to grade laterally into coarser materials. The clay layer generally dips at the same slope (toward the southwest) as the present surface of Yuma Valley.

\section{Clay B}

Clay B, the informal designation applied to the upper clay unit, underlies western Yuma Mesa and extends to the edge of Yuma Mesa. Clay B is approximately 10-15 ft thick in most places and has an average altitude of $100 \mathrm{ft}$ below sea level (Olmsted and others, 1973). Clay B is greater in areal extent than clay A and probably extended farther west before it was eroded during the formation of Yuma Valley. This clay is difficult to distinguish toward the northwest. Clay B might underlie much of the city of Yuma. Similar to clay A, clay B grades laterally into coarser materials, particularly toward the southwest (Olmsted and others, 1973). Restriction of vertical flow attributed to clays (Olmsted and others, 1973) may result in the ground-water mound associated with irrigation areas beneath Yuma Mesa. For example, Olmsted and others (1973) reported a difference of $35 \mathrm{ft}$ between the water table and the hydraulic head at the top of the underlying coarse-gravel unit at the ground-water mound under Yuma Mesa.

\section{Lower, Middle, and Upper Fill Units}

The lower, middle, and upper fill units, which are part of the upper, fine-grained zone described by Olmsted and others (1973) generally are fine grained in texture. These units comprise the following stratigraphic units from Olmsted and others (1973): (1) uppermost sections of the older alluvium, (2) younger alluvium, and (3) windblown sand within the valleys and Yuma Mesa. The younger alluvium comprises all the alluvial deposits related to the most recent cycle of deposition, that currently represents the most exposed sediment at the surface. Much of the ground-water recharge from irrigation occurs through the upper fine-grained zone, resulting in many areas of high water levels (Olmsted and others, 1973). Ground-water flow is mainly vertical through the upper fine-grained zone (Olmsted and others, 1973). The thickness averages $100 \mathrm{ft}$ under Yuma and South Gila Valleys and 170-180 ft under Yuma Mesa (Olmsted and others, 1973).

\section{Geologic Structures Affecting Ground-Water Flow}

Geologic structures, such as the Algodones Fault and areas of high bedrock, can affect the direction of ground-water flow (fig. 2). Faults can be conduits for, or barriers to, groundwater flow. Enhanced permeability usually is associated with increased secondary permeability along fracture zones and is not considered a prominent feature in the Yuma area. A fault can be a barrier to flow for two reasons: (1) juxtaposition of low-permeability materials and relatively high-permeability materials, and (2) low-permeability material (fault gouge) in the fault zone (either from pulverization of material or deposition of minerals along the fault) that forms a barrier to flow across the fault. Juxtaposition is depicted in the HFM discussed in this report. Faults that contain fault gouge are not identified individually here, but often are evident owing to water-level changes across structures that are not associated with unit juxtapositions. The ground-water barrier effect is evident in the Yuma area. Offsets of the water table on the Upper Mesa appear to be associated spatially with the Algodones Fault and are most likely the result of slightly permeable material along the fault zone (Olmsted and others, 1973).

Areas of shallow bedrock can affect ground-water flow because thin, permeable sediments overlying the bedrock are less transmissive than areas of thicker sediments of equivalent permeability. The amount of ground-water flow generally is reduced, resulting in increased ground-water levels on the upgradient side of the shallow bedrock. The development of the ground-water mound under Yuma Mesa may be related to the Yuma basement high (fig. 2).

Analyses of gravity data collected in previous studies (Mattick and others, 1973) by using new computational methods provide new estimates of the altitude of bedrock 
at the Yuma basement high. For this study, models of the subsurface density distribution along three gravity profiles across Yuma Mesa were constructed to simulate the thickness and extent of low-density alluvial deposits overlying highdensity crystalline basement. These data were not included in the HFM because data for the top of bedrock were insufficient to include in the model. Results of the gravity modeling are discussed in Appendix A.

Surface geophysical surveys were done to define areas of shallow bedrock related to the gravity anomaly on Yuma Mesa, and the trace of the Algodones Fault on Yuma Mesa and Yuma Valley. In addition, the thickness and extent of fine-grained soil units were investigated within Yuma Valley and South Gila Valley. This work largely was done to test the utility of these methods for resolving depth to bedrock and extent of fine-grained units. Density contrasts related to bedrock were identified successfully by using seismic methods and time-domain electromagnetic (TDEM) methods. TDEM methods identified shallow fine-grained sediments up to several hundred feet below land surface. The bulk of this work was carried out in conjunction with The University of Arizona, Department of Geological Engineering, Geophysics Field Camp class of 2005. Results from the surface geophysical surveys are discussed in Appendix B; these survey results were not included in the HFM because these data did not provide sufficient information to model the bedrock. Furthermore, it was unclear whether the identified fine-grained sediments were related to the extensive clay A and clay B units identified by Olmsted and others (1973).

\section{Hydrogeologic Framework Model}

A 3D HFM was constructed to represent the HGUs and major structures in the Yuma area (fig. 4, tables 1 and 2). The HFM provides a mechanism to systematically compile and visualize the stratigraphy of the HGUs. The HFM comprises HGUs that are spatially extensive and have similar geologic and water-bearing properties. HGUs in the HFM are the most important units with regard to regional ground-water flow, as identified in previous studies, particularly by Olmsted and others (1973). The 3D configurations of the HGUs in the HFM, including the spatial extents and thicknesses, can be incorporated into the ground-water flow model constructed by Reclamation.

\section{Construction of the Hydrogeologic Framework Model}

The unconsolidated sediments and consolidated rocks were subdivided into eight HGUs (table 1). The HFM is spatial data that represent the lateral and vertical extent of the eight HGUs above (and including) the Bouse Formation and associated geologic structures. The datum of the HFM grid is the Universal Transverse Mercator (UTM) projection Zone 11, North American Datum 1927 (NAD 27). The north-south-oriented HFM grid shows the south boundary at UTM northing 3585000 meters, the north boundary at
UTM northing 3635000 meters, the west boundary at UTM easting 690000 meters, and the east boundary at UTM easting 755000 meters (fig. 4). The HFM grid has a variable horizontal and vertical resolution. The horizontal resolution of the land surface, clay A, clay B, and the coarse-gravel unit are about 300 meters in the north-south and east-west directions. The horizontal resolution of all other units ranges from 500 to 600 meters in both directions. The vertical resolution ranges from 0 to the maximum thickness of each HGU. Software constraints require that the HFM grid be constructed for a bounding rectangle, but the gridded surfaces can be truncated at any lateral or vertical boundary. The altitude of the HFM extends from $5,000 \mathrm{ft}$ below to $3,500 \mathrm{ft}$ above the vertical datum (altitude of $0 \mathrm{ft}, \mathrm{NGVD} 29$ ) to encompass nearly all of the aquifer units in the region. Because altitude data for the HGUs are sparse in the Mexico portion of the HFM, no effort was made to accurately represent the HGUs in that area. The top surfaces of the HGUs in the Mexico portion are constant or decrease steadily toward the HFM bottom. A number of software packages were selected for various parts of the HFM construction process. Each software package was chosen for its proficiency in a particular task and (or) suitability for project needs, but other software packages could have been used.

Spatial data, such as digital elevation, outcrop, and borehole information, were manipulated using ArcGIS ${ }^{\circledR}$ [Geographic Information Systems (GIS)] software. Gridded surfaces were constructed by using Dynamic Graphic's EarthVision ${ }^{\circledR}$ software. The HFM also was constructed by using EarthVision software that makes it possible for 3D models to be created, visualized, and updated quickly. EarthVision is designed to accurately represent stratigraphic and structural relations of sedimentary basins, including deposition, erosion, and unconformities, as well as truncation of units and faulting. Grids representing HGU geometries were developed within the HFM and visualized and processed by using EarthVision.

\section{Modeled Hydrogeologic Units}

The oldest and stratigraphically lowest HGU, the Bouse Formation and other older undifferentiated rocks, represents the "poorly water-bearing rocks of pre-Tertiary age through Pliocene age" determined by Olmsted and others (1973). Next, the Pliocene transition zone and the Pliocene to Holocene wedge zone defined by Olmsted and others (1973) are combined and referred to in this report as the "undifferentiated lower unit". Because of the possible significance of the fine-grained deposits to the hydrology, the Pliocene to Holocene upper fine-grained zone, described by Olmsted and others (1973), that overlies the wedge zone, is split into five HGUs to identify the extent of two relatively extensive clays, clay A and clay B. The rest of the upper finegrained zone of Olmsted and others (1973) is split by clay A and clay B into the lower, middle, and upper fill units (table 1). The fill units have similar textural properties and are separated only for the purpose of defining material between the coarsegravel unit, the clay units, and the land surface. 


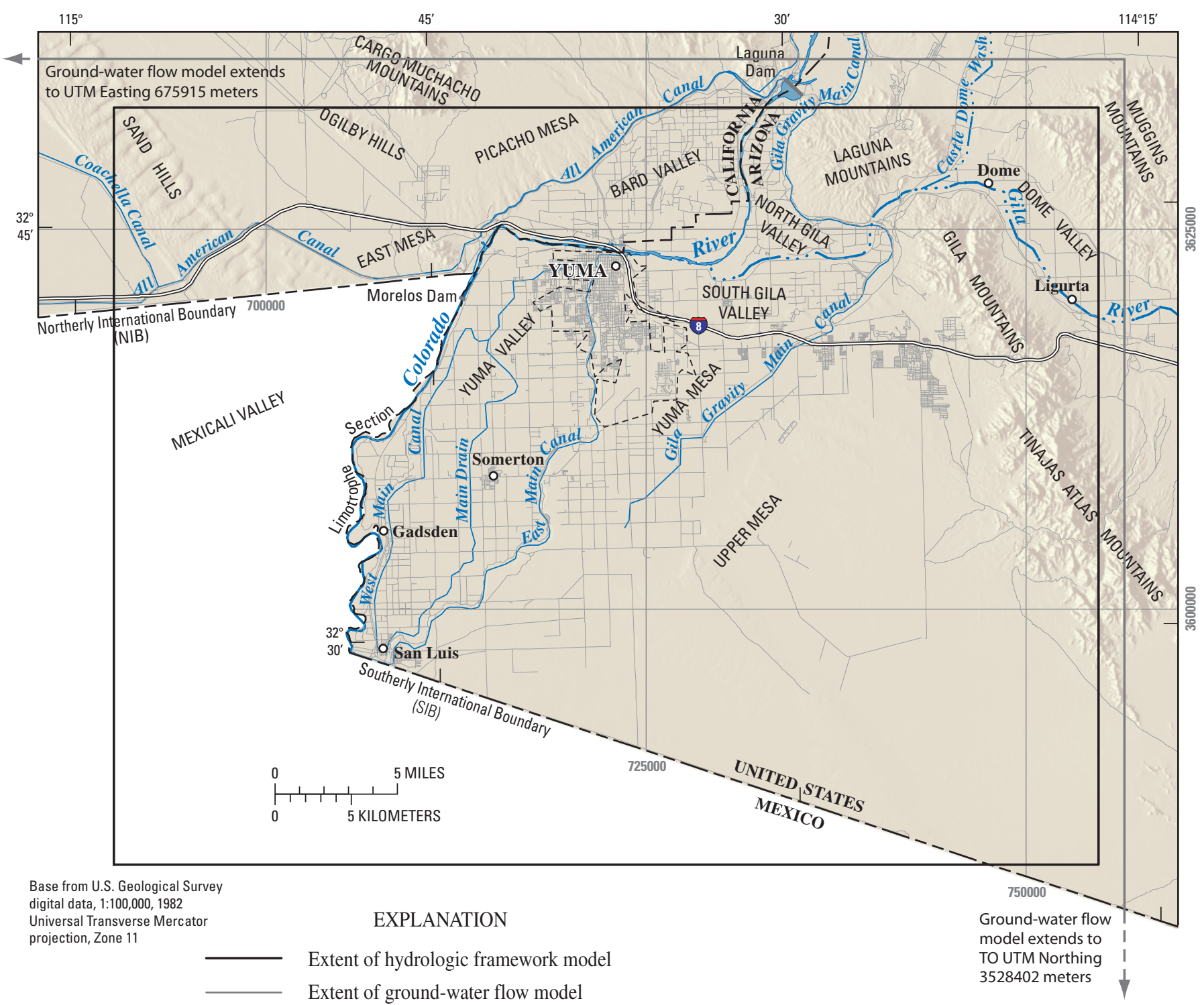

Figure 4. Extent of the hydrogeologic framework model (HFM) and the ground-water flow model (William Greer, hydrologist, Bureau of Reclamation, written commun., 2005). 
Table 2. Data sources for water-bearing deposits included in the hydrogeologic framework model. Data sources are used to define the top of a unit, while the base is defined by a composite of altitude of stratigraphically lower units. The units are listed in stratigraphic stacking order in the hydrogeologic framework model.

\begin{tabular}{|c|c|c|c|c|c|}
\hline $\begin{array}{c}\text { Hydrogeologic } \\
\text { unit }\end{array}$ & $\begin{array}{l}\text { Topographic } \\
\text { data }\end{array}$ & $\begin{array}{l}\text { Borehole lithology } \\
\text { (Appendix B, } \\
\text { Olmsted and } \\
\text { others, 1973; } \\
\text { USGS files) }\end{array}$ & $\begin{array}{c}\text { Borehole } \\
\text { geophysics } \\
\text { (USGS and } \\
\text { Reclamation data) }\end{array}$ & $\begin{array}{l}\text { Maps of extent and } \\
\text { altitude of units }\end{array}$ & Structures \\
\hline Upper fill & $\mathrm{X}$ & --- & --- & --- & none \\
\hline Clay B & $\mathrm{X}$ & $\mathrm{X}$ & --- & $\begin{array}{l}\mathrm{X} \\
\text { (Figure 22, Olmsted and } \\
\text { others, 1973) }\end{array}$ & $\begin{array}{l}\text { Alluvial escarpments (Plate 7, } \\
\text { Olmsted and others, 1973) }\end{array}$ \\
\hline Middle fill & $\mathrm{X}$ & $\mathrm{X}$ & --- & \begin{tabular}{l}
\multicolumn{1}{c}{ X } \\
(base of clay B from \\
Figure 22, Olmsted and \\
others, 1973)
\end{tabular} & none \\
\hline Clay A & $\mathrm{X}$ & $\mathrm{X}$ & --- & $\begin{array}{l}\mathrm{X} \\
\text { (Figure 21, Olmsted and } \\
\text { others, 1973) }\end{array}$ & none \\
\hline Lower fill & $\mathrm{X}$ & $\mathrm{X}$ & --- & $\begin{array}{c}\text { X } \\
\text { (base of clay A) from Figure 21, } \\
\text { Olmsted and others, 1973) }\end{array}$ & none \\
\hline Coarse-gravel unit & $\mathrm{X}$ & $\mathrm{X}$ & $\mathrm{X}$ & $\begin{array}{l}\text { X } \\
\text { (Plate 7, Olmsted and } \\
\text { others, 1973) }\end{array}$ & $\begin{array}{l}\text { Major discontinuities in top } \\
\text { of coarse-gravel zone } \\
\text { (Plate 7, Olmsted and } \\
\text { others, 1973) }\end{array}$ \\
\hline $\begin{array}{l}\text { Undifferentiated } \\
\text { lower units }\end{array}$ & $\mathrm{X}$ & $\mathrm{X}$ & $\mathrm{X}$ & $\begin{array}{l}\text { X } \\
\text { (base of coarse-gravel zone } \\
\text { from Plate 7, Olmsted and } \\
\text { others, 1973) }\end{array}$ & Algodones fault \\
\hline $\begin{array}{l}\text { Bouse Formation } \\
\text { and other older } \\
\text { undifferentiated } \\
\text { rocks }\end{array}$ & $\mathrm{X}$ & $\mathrm{X}$ & --- & $\begin{array}{l}\text { X } \\
\text { (Figure 15, Olmsted and } \\
\text { others, 1973) }\end{array}$ & $\begin{array}{l}\text { Faults offsetting Bouse } \\
\text { Formation (Figure 15, } \\
\text { Olmsted and others, 1973) }\end{array}$ \\
\hline
\end{tabular}




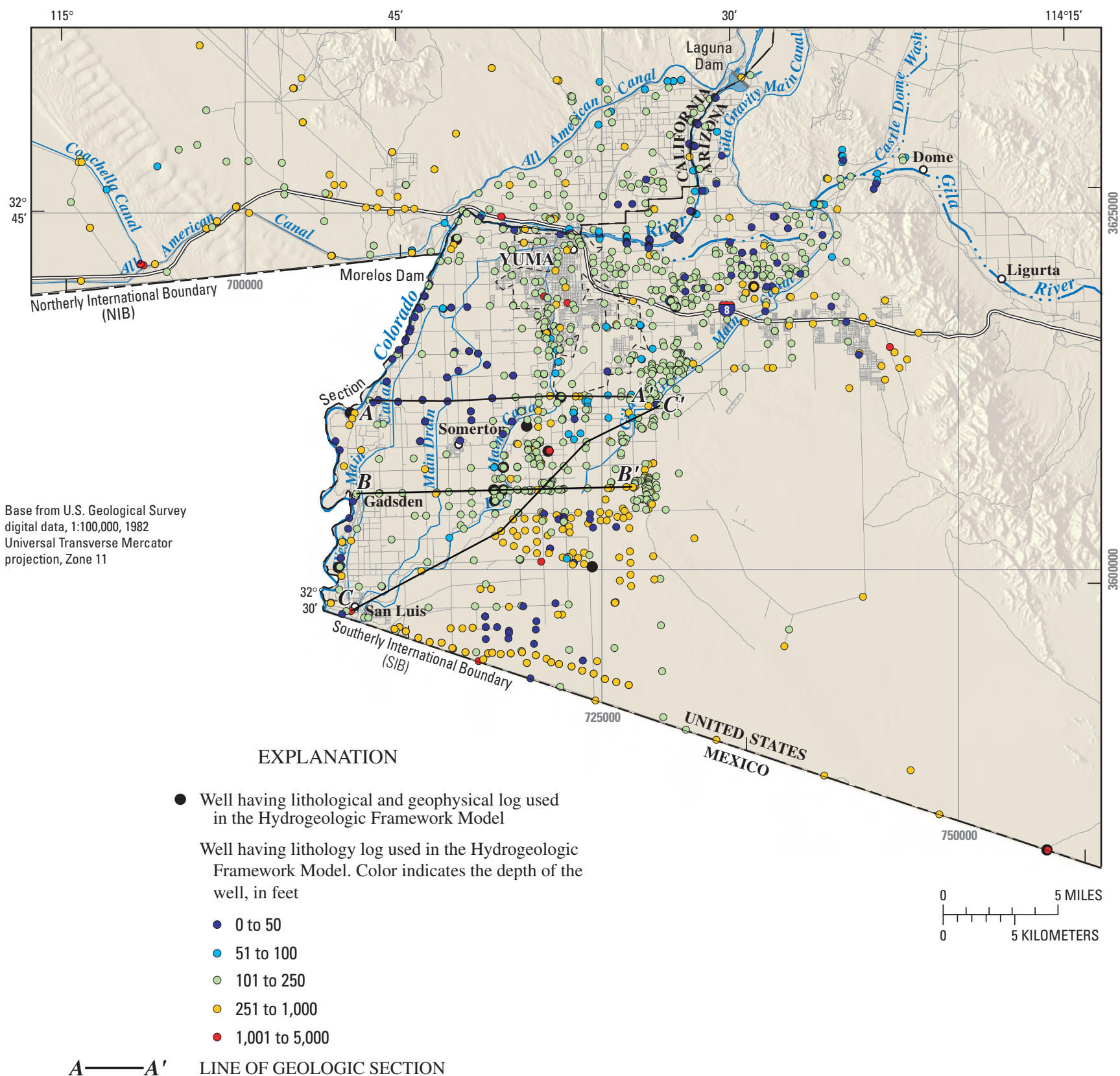

Figure 5. Locations of wells having geological and geophysical logs used in the hydrogeologic framework model.

\section{Data Input}

The construction of the HFM involves the use of data from several sources to define the top surface and extent of each HGU horizon (fig. 5). Existing data for defining hydrogeologic surfaces, such as the land surface and the top of a HGU, are topographic data from DEMs, borehole lithology (lithologic descriptions from drillers' and geologists' logs), borehole and surface-geophysical interpretations, maps of the extent and altitude of units from previous work (Olmsted and others, 1973), and location data of geologic structures (table 2). Some data sources, such as lithologic logs, were simplified to represent the appropriate scale.
New surface-geophysical data collected for this report in targeted areas in Yuma Valley, South Gila Valley, and Yuma Mesa, and cross sections from Olmsted and others (1973), were useful for refining the conceptual model used to build the HFM, but these data were not used specifically in the construction of the HFM. The top and bottom altitudes of several stratigraphic surfaces in some of the cross sections in Olmsted and others (1973) do not match the surface altitudes on maps in Olmsted and others (1973). In addition, data from new wells drilled since the cross sections were created have improved geologic interpretations along the cross sections. 


\section{Topographic Data}

Digital elevation data from the 7.5-minute National Elevation Data (DEM; http://seamless.usgs.gov, accessed 2005) were merged into a single DEM in UTM projection Zone 11, NAD 27, with a grid spacing of approximately $98 \mathrm{ft}$ (30 m). Altitude data in Mexico representing the topography were available at a resolution of $295 \mathrm{ft}(90 \mathrm{~m})$. Despite the differences in resolutions, the data were merged into a single DEM of the study area and sampled at a spacing of $500 \mathrm{ft}$. Although not checked rigorously, the topographic data appear to be consistent with reported land-surface altitudes at borehole locations.

\section{Borehole Lithology}

Lithology data from boreholes in the Yuma area were compiled and manipulated to obtain lithologic contacts between HGUs (fig. 5). Lithology logs of drill cuttings and core material provided the majority of information to delineate spatial extent and thicknesses of shallow water-bearing units and confining beds. Data were assembled from Olmsted and others (1973) and Reclamation and USGS archives. All lithology logs reproduced in Olmsted and others (1973, Appendix B) and maps showing lithology log locations and extents of units in Olmsted and others (1973, figs. 21 and 22, pl. 7) were used in the construction of the HFM. The lithology logs were distributed widely across the study area and several logs show penetration greater than a 1,000-ft. depth and several show penetration into bedrock. The maps were digitized, attributed, and georeferenced by using ArcGIS®. The primary source for information about the top and bottom surfaces of clay A and clay B was Olmsted and others (1973, figs. 21 and 22, respectively). Plate 7 from Olmsted and others (1973) was used to define the top surface of the coarse-gravel unit. The unit extents from Olmsted and others (1973) were used as a guide in constructing the HFM and not as direct input.

The lithologic units were correlated and grouped into HGUs on the basis of the textural and lithologic descriptions recorded on the logs. Then, the depths to the various HGU horizons were extracted. The altitude of the top of the HGU horizon was calculated by subtracting the depth from the landsurface altitude. If the land-surface altitude was not reported in the lithology logs, DEMs were used to interpolate the landsurface altitude at the borehole. The $x, y, z$ coordinates of the top of the HGU horizons were defined by the location of the borehole and these altitudes.

\section{Geologic Structures Affecting Ground-Water Flow}

Geologic structures which are thought to affect groundwater flow on a regional scale were used in the construction of the HFM (fig. 2). Maps showing the surface expression of faults that have major offsets (Olmsted and others, 1973, pl. 3) and other structures were used to incorporate discontinuities in the top and bottom altitudes of the Bouse Formation and other older undifferentiated rocks. The top of the coarse-gravel unit was offset by vertical discontinuities from Olmsted and others (1973, pl. 7). Faults and other structures in the model area can dip at almost any angle, but most are high-angle faults (greater than 60 degrees). These high-angle faults are simplified in the HFM as vertical features.

\section{Gridding of Hydrogeologic Unit Horizons}

The gridded surfaces defining the HGU horizons were computed from top and bottom surfaces of HGUs (see the "Data Inputs" section). EarthVision's minimum-tension algorithm (incorporating faulting, where appropriate) was used to calculate the grid. The minimum-tension algorithm calculates a smooth surface that closely fits the input data values by using biharmonic-cubic spline interpolation techniques (Dynamic Graphics, Inc., 1999). This process results in a trend surface in areas of sparse data, but the grid accurately represents the data points. Because the algorithms can extrapolate or interpolate grid cells that may be higher than land surface, each grid was limited by the topographic surface.

The accuracy of individual gridded surfaces depends on the available defining data and the complexity of the geologic unit being modeled. For example, because of their relatively simple geometry, planar bedded units can be represented accurately with only a few data points, whereas faulted and folded rocks with more complex geometries are more difficult to represent even with a large number of data points. Some gridded HGU surfaces were relatively well defined by numerous well-distributed data. Other gridded surfaces, such as those HGUs having few or no outcrops, were relatively poorly defined. In general, the stratigraphically lower HGUs are less defined than shallow units owing to sparse data and increased structural complexity related to the Algodones Fault (Olmsted and others, 1973, fig. 15).

In areas that have more data, the gridded surfaces generally are acceptable; in areas that have sparse data, the gridded surfaces are more suspect. In areas of sparse data, gridded surfaces were enhanced by using specified "control points" to ensure that the surfaces followed structural trends and honored data.

\section{Building the Model}

The HFM was constructed in EarthVision by stacking the gridded HGU horizons (table 1) in a stratigraphic sequence into a 3D volumetric solid. EarthVision uses geologic operations on HGUs to determine how the horizons of the HGUs are used when building the model and how intersecting horizons are assembled within the volumetric solid. The topographic surface is used as a surface to truncate all older units. A visualization of the HFM as a block diagram (fig. 6) shows the internal and external shape of the HGUs.

\section{Description of the Hydrogeologic Framework Model}

The HGUs as they are depicted in the HFM are described below. The extent and thickness of each HGU from the HFM may differ somewhat from those described by Olmsted and 
others (1973). The distribution of the data sources and the thickness of the HGU as simulated in the HFM are shown for key HGUs in figures 7, 8, and 9 in this report.

\section{Bouse Formation and Other Older Undifferentiated Rocks}

The poorly water-bearing rocks of Tertiary age, which are below the main units of interest, are represented by the Bouse Formation and any other older undifferentiated rocks. For modeling purposes, these units were combined into one HGU. This HGU forms the base of the model down to an arbitrary altitude of $-5,000 \mathrm{ft}$. The top of the HGU is based on the inferred extent and configuration of the Bouse Formation described by Olmsted and others (1973, fig. 15) and on additional data from well $\log$ s that penetrate the Bouse Formation. Structures, including the Algodones Fault, were used to simulate vertical offsets in the top of this HGU. The HGU outcrops in the Gila Mountains, and elsewhere, the top surface altitude is generally lower than those of the other HGUs in the HFM domain.

\section{Undifferentiated Lower Unit}

The lowest part of the main water-bearing deposits are the undifferentiated lower units (fig. 3). The undifferentiated lower units are thickest in the northwest and thinner toward the Gila and Laguna Mountains to the northeast and toward the Yuma Hills to the southeast, similar to the overall wedge shape of the wedge zone that the unit typically represents. Although represented throughout the HFM, often with great thickness, much of this unit is below the typical "water-bearing deposits". The base of this unit, where it meets the top of the Bouse Formation in the HFM, often is arbitrary owing to lack of data defining the lowest fluvial strata at the bottom of the transition zone. The top of this unit is defined as the base of the coarse-gravel unit. Data sources for the base of the coarsegravel unit are the well logs identified by Olmsted and others (1973, pl. 7 and Appendix B) and additional geophysical logs. Although little offset is evident, the Algodones Fault is used during the gridding process to simulate vertical offsets across the top of the HGU.

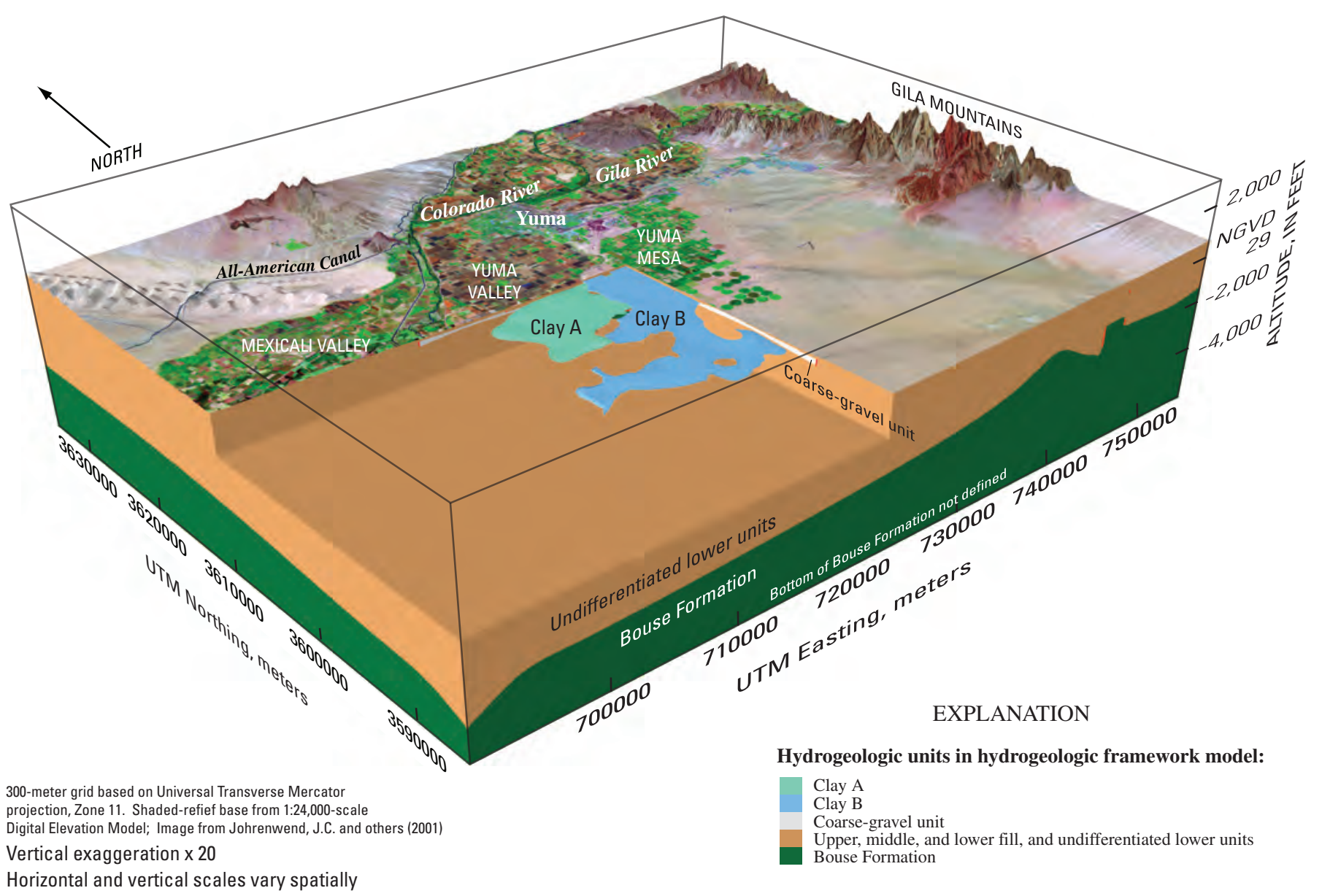

Figure 6. Oblique view of block diagram of the hydrogeologic framework model. The extent of the HFM is shown on figure 4. 


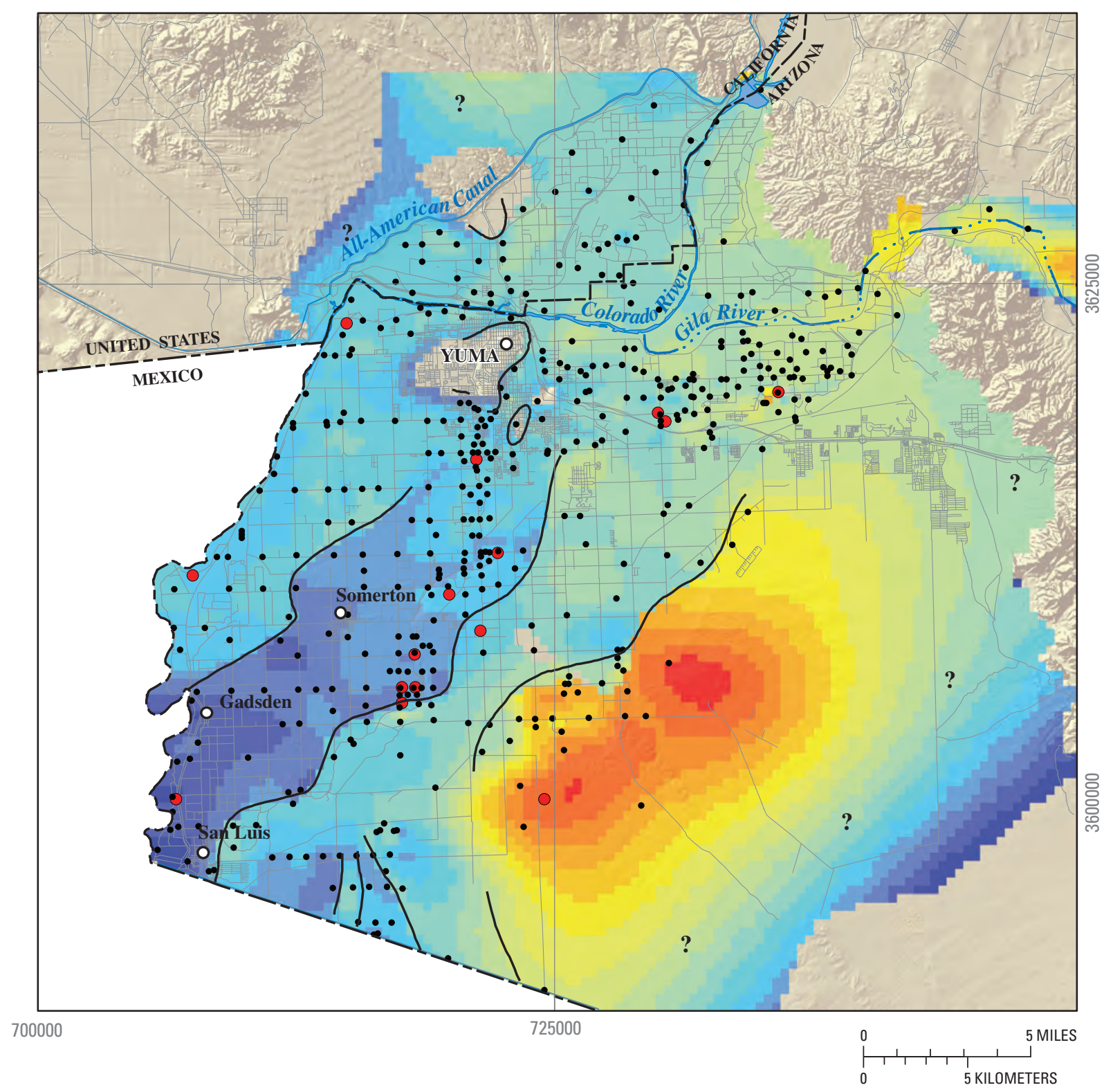

\section{EXPLANATION}

Well penetrating top of coarse gravel unit indicated by resistivity logs

- Well penetrating top of coarse-gravel unit indicated by geologic logs

- Major discontinuity in top of coarse-gravel unit

? Unknown altitude of top of coarse-gravel unit
Altitude of top of coarse-gravel unit, in feet

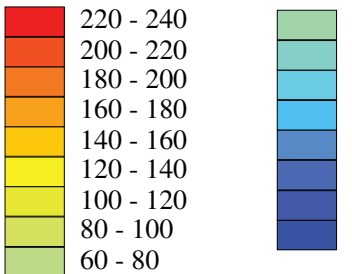

$40-60$ $20-40$

$0-20$

$-20-0$

$-40--20$

$-60--40$

$-80--60$

$-100--80$

Figure 7. Extent and thickness of the coarse-gravel unit and locations of geologic and resistivity logs used to identify the top elevation of the unit. 


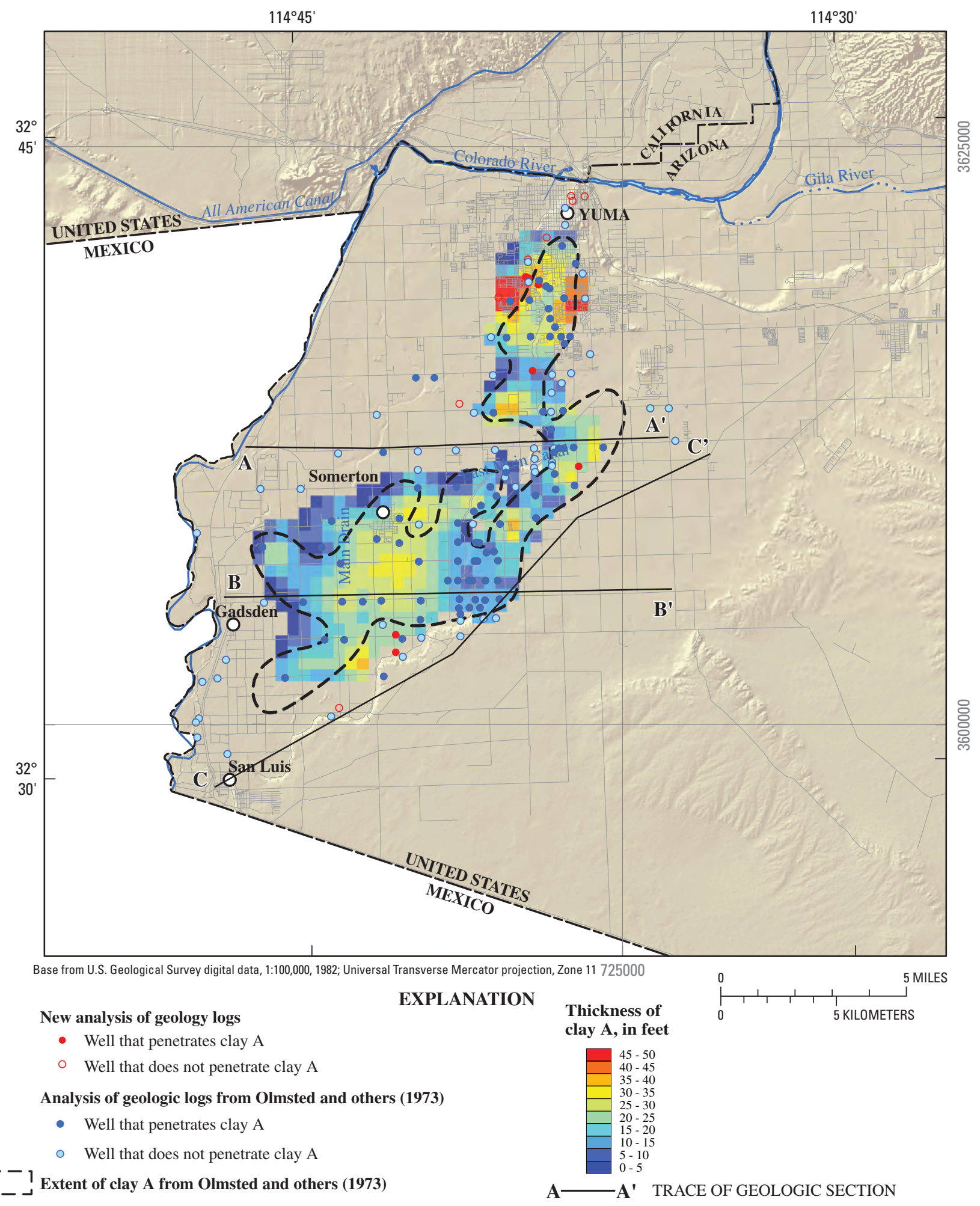

Figure 8. Extent of clay A according to Olmsted and others (1973), the new extent of clay A described in this report, and locations of wells that either penetrate or do not penetrate clay A. 


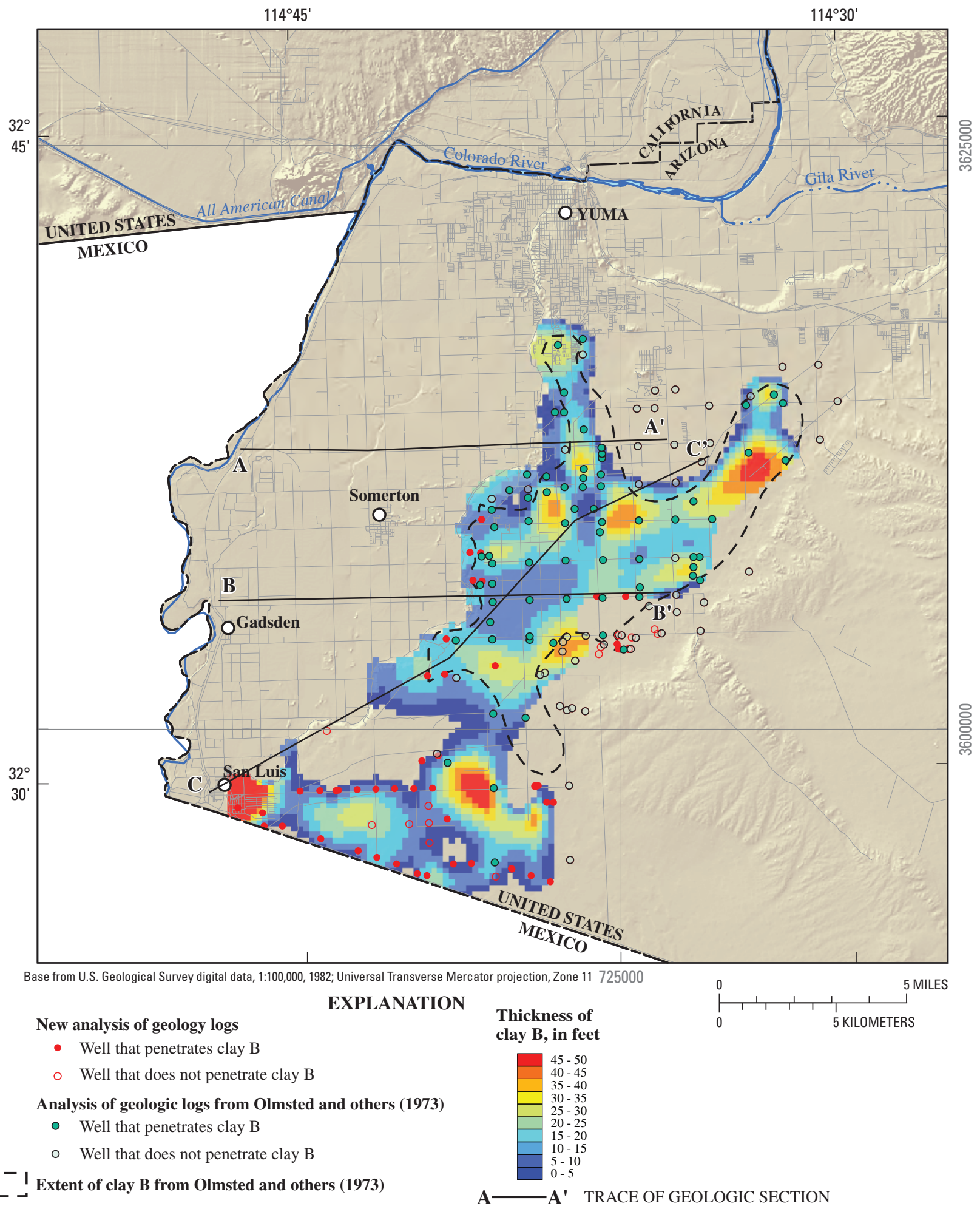

Figure 9. Extent of clay B according to Olmsted and others (1973), the new extent of clay B described in this report, and locations of wells that either penetrate or do not penetrate clay $B$. 


\section{Coarse-gravel unit}

The coarse-gravel unit underlies much of Yuma Valley and Yuma Mesa (Olmsted and others, 1973; fig. 3). Nearly all wells used for water extraction penetrate the coarsegravel unit, so a large number of lithologic logs are available to define the top of this HGU surface (Olmsted and others, 1973, pl. 7 and Appendix B). Geophysical logs from USGS and Reclamation files show distinct patterns within the gravel and were used to supplement these lithologic logs. The HGU altitude and extent in the HFM, as well as the input data points, are shown in figure 7.

The coarse-gravel unit generally slopes gently downward to the south and southwest. Olmsted and others (1973, pl. 7) outline structural discontinuities along the top surface of the coarse-gravel unit. More recent logs also suggest surface discontinuities. These discontinuities are attributed to a sequence of deposition and subsequent erosion of gravels to produce terraces, and were used in the construction of the HGU surface. As a result, the top and bottom altitudes are highest along the eastern extent of the unit and become lower in step-wise fashion toward the west.

\section{Lower Fill}

The lowest portion of the upper, fine-grained zone (Olmsted and others, 1973), termed the "lower fill" in this report, is concentrated in Yuma Valley and along the southwestern portion of the model area. The top of this HGU is defined as the base of the older clay unit, clay A, and the bottom is defined as the top of the coarse-gravel unit (Olmsted and others, 1973, fig. 21 and Appendix B). The HGU is very thin because clay A is not far above the coarse-gravel unit.

\section{Clay A}

Clay A mainly underlies Yuma Valley and extends into the western edge of Yuma Mesa (fig. 3). The top of clay A is identified on lithologic logs (Olmsted and others, 1973, fig. 21 and Appendix B). The HGU altitude and extent in the HFM, as well as the data points having altitudes of the top and bottom surfaces of the unit, are shown in figure 8 . The unit is relatively thin and appears to dip slightly toward the southwest. By using more recent lithologic data in the HFM, clay A extends further to the west in Yuma Valley near the city of Yuma.

\section{Middle Fill}

The middle fill of the upper, fine-grained zone described by Olmsted and others (1973) is concentrated in Yuma Valley and along the southwestern portion of the model area. In the HFM, the undifferentiated fill extends further to the north and east. The top of this HGU is defined as the base of the younger clay unit, clay B, and the bottom is defined as the top of the lower fill, or clay A, where it exists (Olmsted and others, 1973, fig. 22 and Appendix B). The HGU still is relatively thin.

\section{Clay B}

Clay B Mainly underlies western Yuma Mesa and extends to the edge of Yuma Mesa (fig. 3). The top of clay B is identified on lithologic logs (Olmsted and others, 1973, fig. 22 and Appendix B). The HGU altitude and extent in the HFM, as well as the data points having altitudes of the top and bottom surfaces of the unit, are shown in figure 9. The fine-grained unit is relatively thin (even thinner than clay A) but extends much further east than clay A. As described previously, clay B is truncated by Yuma Valley. Clay B likely extended further to the west, but these areas have been eroded during the downcutting events by the Colorado River that produced the present Yuma Valley (Olmsted and others, 1973). In the HFM, clay B extends further southward to the SIB and eastward in the southern areas. This extension is based on reinterpretation of clay strata indicated on lithologic logs by using physical descriptions and strata altitudes. This extension of clay B increases its size by about two-thirds of the original area mapped by Olmsted and others (1973). Clay B might extend further into Mexico, but this cannot be verified without additional data.

\section{Upper Fill}

Generally, the upper fill represents the upper, fine-grained unit above all other units. Stratigraphically, the upper fill is defined as all deposits above clay B. The bottom altitude is defined by the top of the middle fill or by the top of clay B, where it exists. The top altitude is defined by the land surface.

The upper fill is defined to be the stratigraphically highest part of the upper, fine-grained zone (Olmsted and others (1973). The grid resolution and stacking of HGUs from older to younger favors the older HGU when more than one unit is modeled within an HFM grid cell. As a result, the upper fill often is not represented where it does not cover an entire model cell. The fill units are texturally undistinguished, so exposures of the other fill units are identical texturally to exposures of the upper fill. This result, therefore, does not affect the calculated distribution of the coarse-gravel unit or the clay units at the given scale.

\section{Evaluation of the Hydrogeologic Framework Model}

The HFM was evaluated for accuracy by visual inspection of the gridded surfaces for extent and thickness of the HGUs. The HFM was constrained by the extent of HGUs, input data points, and geologic sections described by Olmsted and others (1973) and by newer lithology data.

\section{Comparison of Gridded Surfaces with Previously Defined Extents of Hydrogeologic Units}

Gridded surfaces of the HGU horizons were compared to the input data used to construct the surfaces to assess the accuracy of the gridding processes. Grids of unit thickness 
were constructed to examine areas of potential anomalous thickness. Comparing the gridded surfaces and thickness with the input data provided a suitable method of evaluating the representation of the HGUs in the HFM. Where necessary, a gridded surface was recalculated by using additional "control points" to ensure that the gridded surfaces conformed to the general conceptual model of the hydrogeological framework.

\section{Comparison of Model Sections to Geologic Sections in Targeted Areas}

Hydrogeologic contacts and structures are described along cross sections through Yuma Valley and Yuma Mesa along transects A-A', B-B', and C-C' (figs. 10, 11, and 12). Transect A-A' overlaps with transect C-C' of Olmsted and others (1973), and transect B-B' is the same as transect E-E' described by Olmsted and others (1973). Transect C-C' crosses Yuma Valley and Yuma Mesa along a southwest-tonortheast direction along themiddle transect from the block diagram of Olmsted and others (1973, pl. 10). Visually comparing the vertical slices of the model along traces of the sections C-C' and E-E' described by Olmsted and others (1973) with sections A-A' and B-B' in this report, respectively, provided an acceptable method of evaluating the model representation (figs. 10, 11, and 12). No discrepancies deemed geologically or hydrogeologically significant were recognized on the basis of gross morphology. The model sections retain the basic geometric characteristics from the sections by Olmsted and others (1973) but typically do not include minor features. Discrepancies occurred mainly where HGUs are thin and undulating, or where new or additional well data were available.

\section{Ground Water}

The Colorado and Gila Rivers historically have been the sources of nearly all ground water in the Yuma area. Prior to development of the water resources in the area and construction of upstream reservoirs, the two rivers supplied water to the aquifer by way of direct infiltration from the channels and infiltration of water in parts of the flood plains when annual high flows overtopped river banks. Use of ground water by phreatophytes in the floodplains resulted in a general pattern of shallow ground-water movement away from the river channels. That pattern was superimposed on a regional southerly flow towards the northern part of the Gulf of California where natural discharge occurs. In the Mexicali Valley, a westerly component of flow towards the Salton Sink (west of the study area) likely existed. Some locally derived episodic recharge likely occurred in arroyos from runoff of precipitation in adjacent mountains. This source of water was a relatively small part of the ground-water budget. Contours of water levels in 1925 (Olmsted and others, 1973; fig. 13) indicate the existence of some characteristics of the predevelopment flow system, even though some development of water resources had taken place prior to that time. These contours indicate a general pattern of flow from the Colorado and Gila Rivers southward under Yuma Mesa. A component of flow away from the Colorado
River is evident from the shapes of the contours in Yuma Valley. Westward components of flow from the Colorado River into Mexicali Valley also likely existed. Offsets in water levels across the southwest part of the Algodones Fault indicate the presence of a barrier or restriction to ground-water movement across the fault.

\section{Modern Ground-Water Levels and Flow Patterns}

A number of factors have changed the predevelopment ground-water levels and flow patterns to modern levels and patterns. These factors include the following:

1. Regulation of flows in the Colorado and Gila

Rivers.- Upstream dams have eliminated the annual cycle of flooding that once existed. Extreme flood events on the regulated rivers can occur, but the inundated areas are limited to the channel and some adjacent low-lying land. Also, upstream consumptive use and exports made possible by flow regulation have reduced the surface flows entering the Yuma area. Finally, the diversion of almost all flow in the river at Morelos Dam under normal conditions has eliminated a source of surface water in the downstream reach. Currently, much of the water in that reach is likely inflow from the aquifer.

2. Clearing phreatophytes and irrigating crops on the floodplains. - Application of surface water to crops in areas once occupied by phreatophytes has changed much of the flood plains from sink areas to source areas for ground water.

3. Irrigation on Yuma Mesa.- Excess irrigation of citrus orchards on Yuma Mesa with surface water resulted in a ground-water mound that is as high as $70 \mathrm{ft}$ above the predevelopment water surface.

4. Construction of unlined conveyance channels.Unlined canals in the Yuma area generally lose water to the underlying aquifer.

5. Reduction of sediment in the Colorado River.Impoundment of water in upstream reservoirs has reduced sediment concentrations in the Yuma area, resulting in scour of the river channel and lowering of the watersurface profile in much of the reach. The lower profile contributes to conditions that result in the Colorado River acting as a drain to the ground-water system.

6. Development of networks of surface drains in the valleys.- Drains were constructed for the purpose of lowering the water table under cropland irrigated with surface water.

7. Withdrawal of water from wells in Yuma and South Gila Valleys and on Yuma Mesa.- Water is pumped from drainage wells in Yuma and Gila Valleys for the purpose of maintaining water levels at acceptable distances below the land surface and on Yuma Mesa for irrigation and other purposes. 
Geologic section modified from Olmsted and others (1973, plate 5, Section C - C')

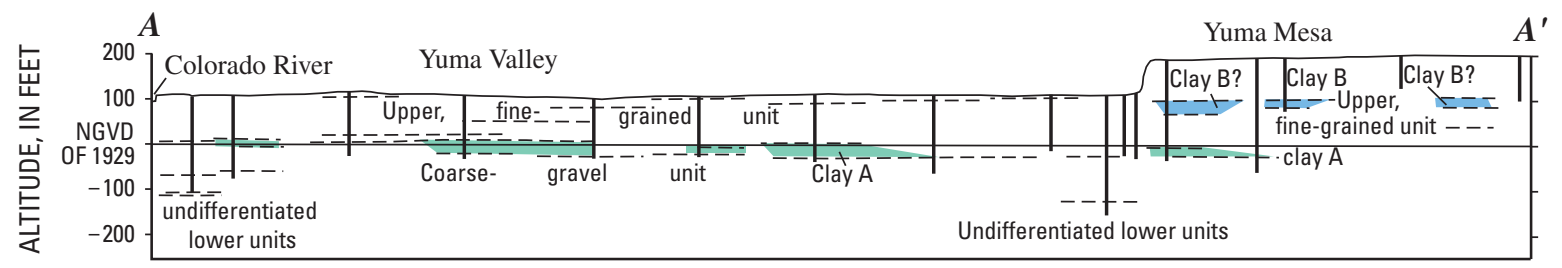

Geologic section from hydrogeologic framework model using only original Olmsted and others (1973) data

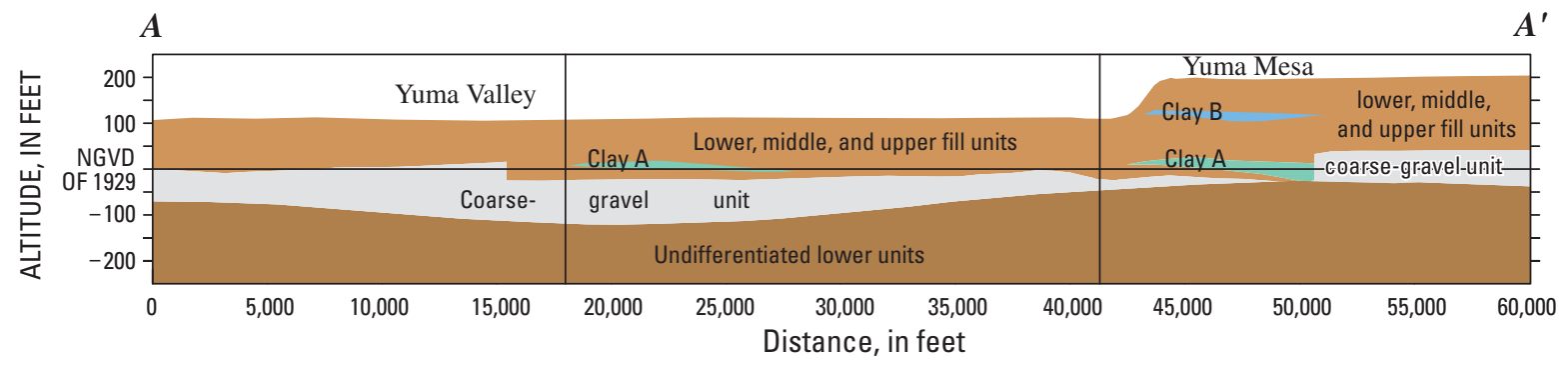

Geologic section from hydrogeologic framework model using new data and original Olmsted and others (1973) data

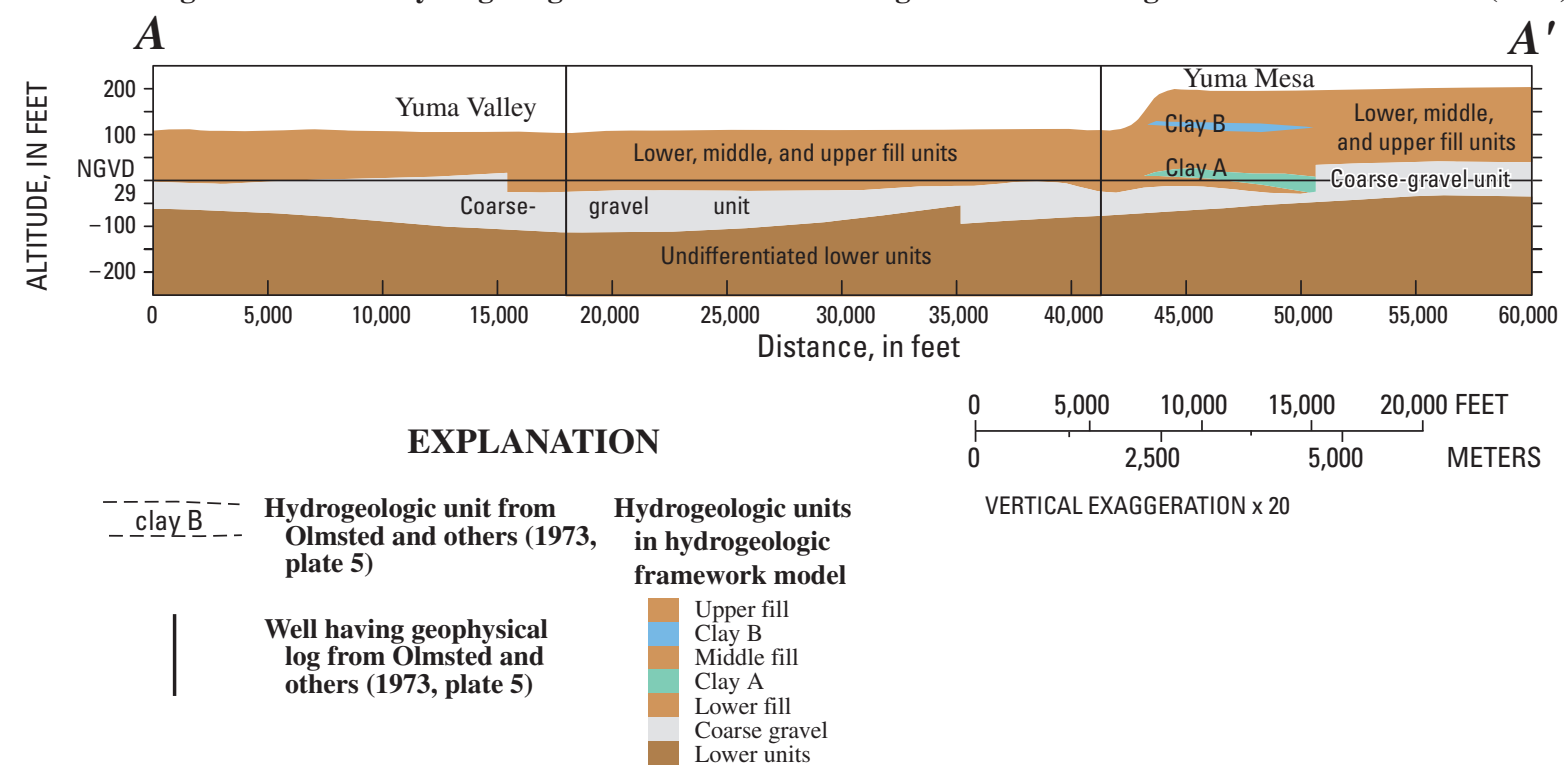

Figure 10. Cross section $A-A^{\prime}$ showing hydrogeologic units in Yuma Valley and Yuma Mesa. 
Geologic section modified from Olmsted and others (1973, plate 5, Section E - E')

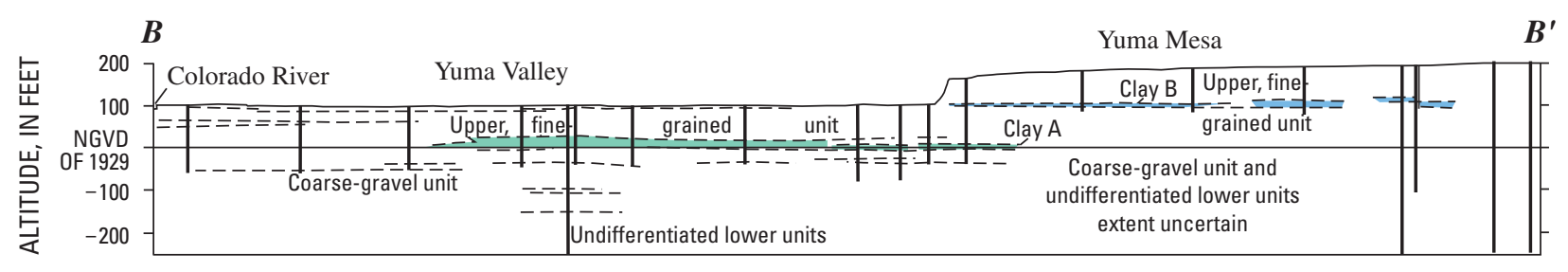

Geologic section from hydrogeologic framework model using only original Olmsted and others (1973) data

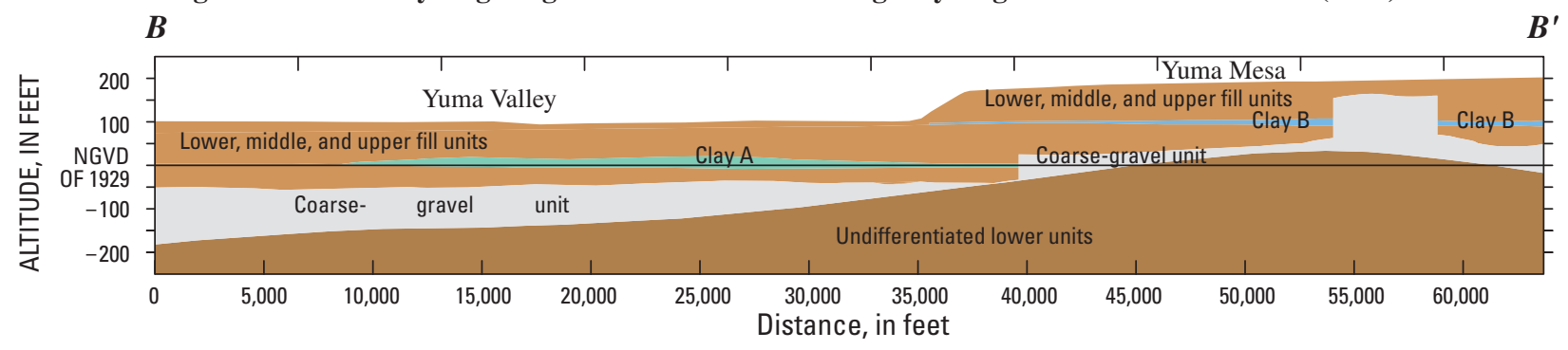

Geologic section from hydrogeologic framework model using new data and original Olmsted and others (1973) data

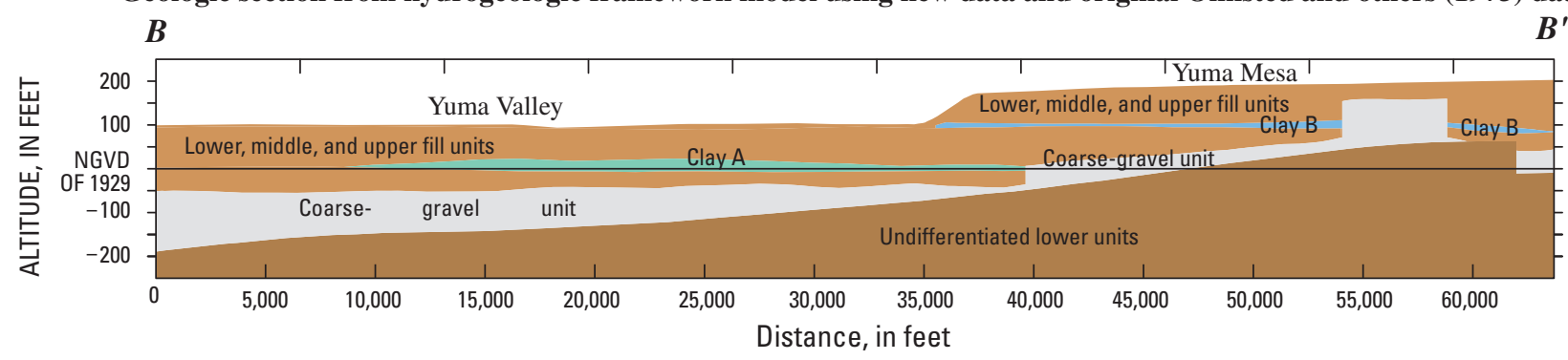

\section{EXPLANATION}

\begin{tabular}{|c|c|c|}
\hline clay $\underline{\mathrm{B}}_{---}^{--}$ & $\begin{array}{l}\text { Hydrogeologic unit from } \\
\text { Olmsted and others (1973, } \\
\text { plate 5) }\end{array}$ & $\begin{array}{l}\text { Hydrogeologic units } \\
\text { in hydrogeologic } \\
\text { framework model }\end{array}$ \\
\hline & $\begin{array}{l}\text { Well having geophysical } \\
\text { log from Olmsted and } \\
\text { others (1973, plate 5) }\end{array}$ & $\begin{array}{l}\text { Upper fill } \\
\text { Clay B } \\
\text { Middle fill } \\
\text { Clay A } \\
\text { Lower fill } \\
\text { Coarse gravel } \\
\text { Lower units }\end{array}$ \\
\hline
\end{tabular}

Figure 11. Cross section B-B' showing hydrogeologic units in Yuma Valley and Yuma Mesa. 

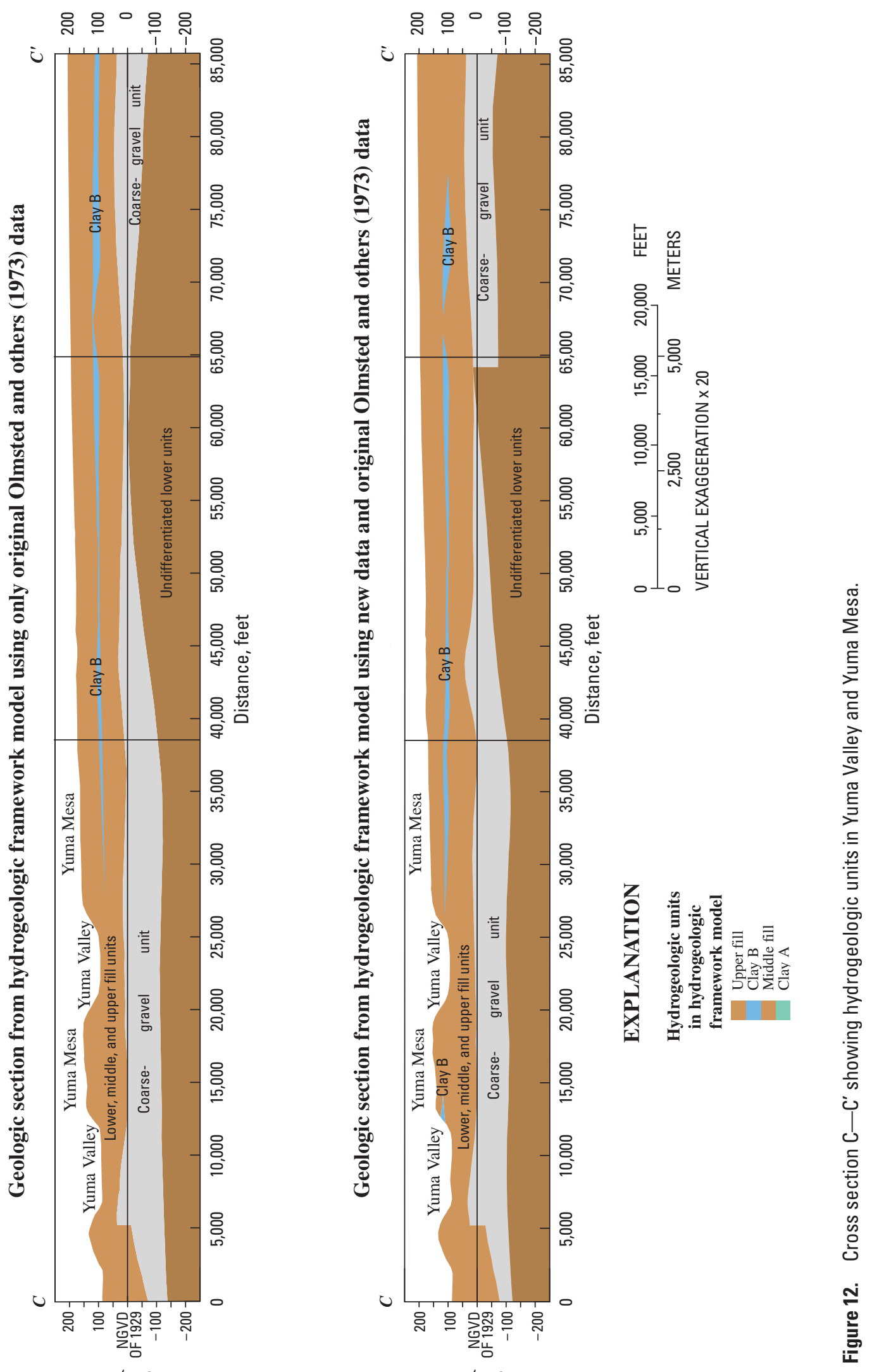


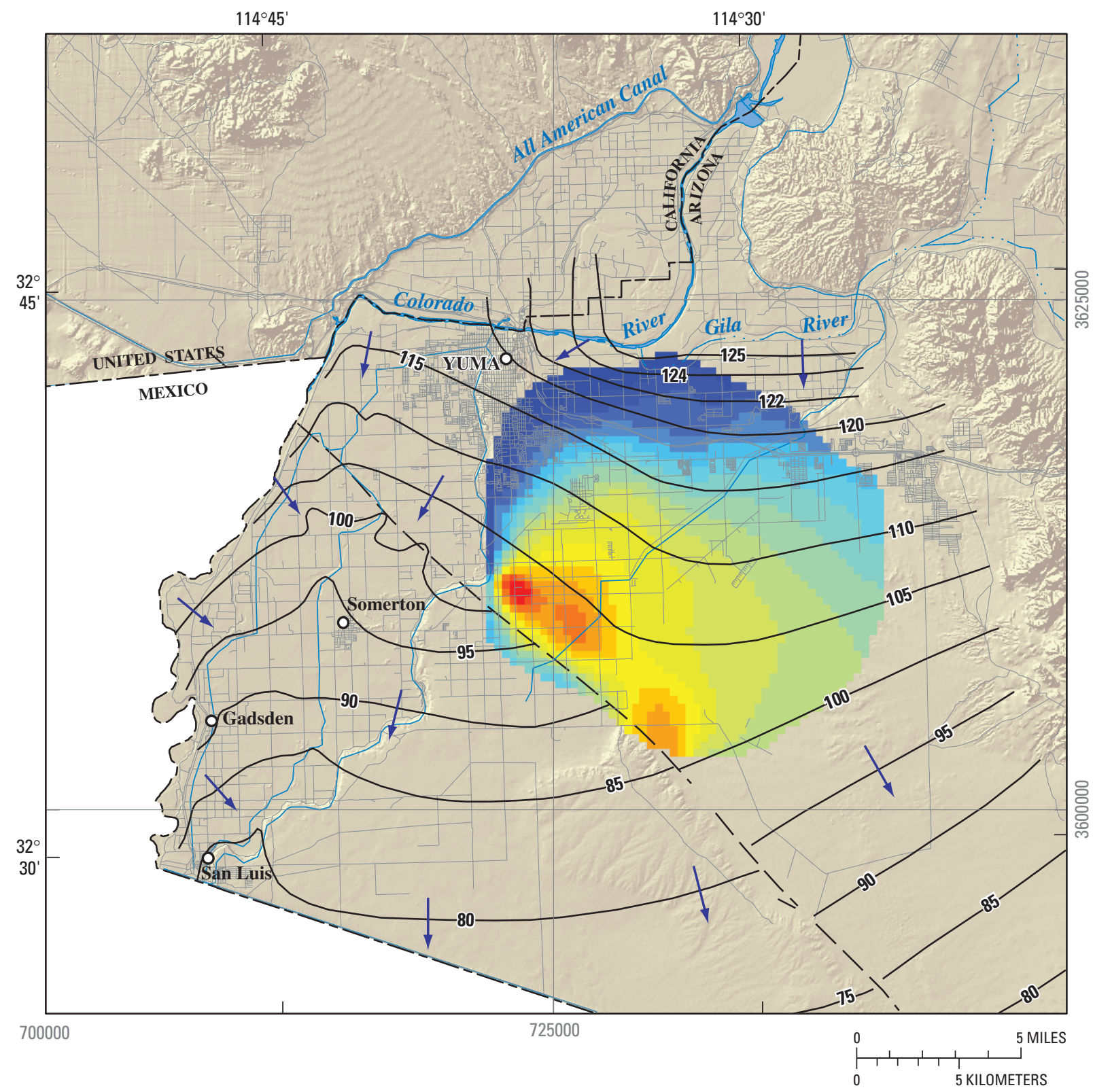

\section{EXPLANATION}

\section{-100 Average water-level contours in 1925 from Olmsted and others (1973), in feet}

$\longrightarrow$ Approximate direction of ground-water flow

— - Algodones fault from Olmsted and others (1973)
Thickness of ground-water mound in 2004 and 2005, in feet. Thickness is calculated as the difference between ground-water level contours for 1925, and contours for 2004 and 2005 shown in figure 14.

$\begin{array}{ll}64-68 & 32-36 \\ 60-64 & 28-32 \\ 56-60 & 24-28 \\ 52-56 & 20-24 \\ 48-52 & 16-20 \\ 44-48 & 12-16 \\ 40-44 & 8-12 \\ 36-40 & 4-8 \\ & 0-4\end{array}$

Figure 13. Thickness of the mound under Yuma Mesa, the assumed extent of the mound used in this report, and contours that connect equal elevations of the water table in 1925. 
To illustrate ground-water levels and flow patterns during modern times, a map was constructed by using water levels measured in wells during 2004-2005 by Reclamation and the USGS (Owen-Joyce and others, 2000). To help constrain the water levels, calculated elevations of some connected surfacewater features were used at selected points. William Greer (Bureau of Reclamation, hydrologist, written commun., 2005) provided digital files with traces of surface-water features and elevations of water surfaces and endpoints of reaches. By using the elevations at the endpoints, elevations were interpolated at regular intervals along the traces. The surfacewater features used included the Colorado and Gila Rivers and surface drains in Yuma Valley. Many canals in the area leak water and influence water levels; however, direct hydraulic connection to the water table is not certain, and elevations of water surfaces in canals were not used. Elevations for endpoints of river reaches were modified to reflect calculated water-surface levels in 2004-2005. Because of sparse data north and west of the All-American Canal, mapping of the surface was limited to the areas in Arizona and California south and east of the canal.

The water-level map for 2004-2005 (fig. 14) indicates horizontal variations in water levels. Water levels also can vary with depth. In areas where ground water is being recharged, shallow ground-water levels can be expected to be higher than deeper ground-water levels. In areas where ground water discharges to the land surface, converse conditions will occur. The map (fig. 14) was constructed by using measurements from existing wells, without regard to the open interval in the well. In most of the area, head differences between the coarsegravel unit and the water table are likely to be small. Loeltz and Leake (1983) give average water levels for piezometers in this depth range at approximately 1-mile intervals along the Colorado River, a line of focused ground-water discharge. Most average head differences between the shallow water levels and deeper water levels in the coarse-gravel unit are $0.5 \mathrm{ft}$ or less. For much of the area, water levels from wells open to the upper, fine-grained zone, the coarse-gravel unit, or both units should reasonably represent the elevation of shallow ground water. An exception might be under the mound beneath Yuma Mesa where vertical head differences of tens of feet may exist.

The water-level contours for 2004-2005 indicate conditions that are similar to conditions in 1965 (Olmsted and others, 1973, fig. 32) and in later years as mapped by Reclamation (Bureau of Reclamation, written commun., 2005). The highest point on the mapped water surface is in excess of $170 \mathrm{ft}$ above sea level at the apex of the groundwater mound under Yuma Mesa. Concentric contours around the apex indicate flow in all directions. The contours are particularly close on the western side of the mound, indicating steep gradients towards the nearby edge of Yuma Mesa. The mound will be discussed in more detail in the following section of this report. Inflow from seepage from the All-American and Gila Gravity Main Canals is apparent in the contours. The contours also indicate that the Colorado River drains the ground-water system along its entire reach.
Loeltz and Leake (1983) also indicate that the Colorado River receives ground water in the reach from Laguna Dam to the NIB. The Gila River also appears to be a drain. Flow into drains in Yuma Valley is indicated by contours that make an upstream traverse before crossing a drain. At the lower end of the drainage network, however, the opposite pattern can be seen, possibly indicating a loss of water from the drain to the aquifer. A southerly flow direction still exists under Yuma Mesa and across the SIB, but water levels near the SIB appear to be several tens of feet lower than they were in 1925. This change likely is the result of ground-water withdrawals along the SIB. Another change since 1925 is a westerly component of ground-water flow in Yuma Valley towards the Colorado River and Mexicali Valley across the limotrophe section.

\section{Ground Water Stored Under Yuma Mesa}

Irrigation at Yuma Mesa for citrus orchards since the mid 1940s has resulted in the development of a ground-water mound (Olmsted and others, 1973). By 1959, water levels in the mound had increased by about $60 \mathrm{ft}$ since predevelopment levels (Jacob, 1960). The mound exists because (1) the rate of applied irrigation exceeded the rate of consumptive use of the citrus groves, thus, the excess water went into subsurface storage; and (2) the rate of horizontal ground-water flow away from the mound has not been sufficient to drain the rising water levels.

Because the mound can be a significant source of water for meeting water-management challenges, Reclamation is interested in obtaining an estimate of the volume of water in the mound. Ground-water level contours indicate areas where ground water has increased since predevelopment conditions. The change in water levels can be used to define a spatial extent of the mound (fig. 13). The spatial extent used in this report includes areas with reasonably calculated water levels. Although water-level contours on figure 14 suggest that the mound extends further to the southeast than is shown on figure 13 , levels in these areas are not well known and these areas are not included.

The volume of water currently stored is calculated as the difference between average water levels from 2004 to 2005 and predevelopment water levels of 1925 (fig. 13) multiplied by the specific yield of the subsurface material at Yuma Mesa. Ground-water level contours were digitized and converted to grids by using EarthVision. The volume between the grids representing current and predevelopment water levels was calculated within the extent shown on figure 13. To obtain an amount of stored ground water, the volume between the grids was multiplied by a possible range of values of specific yield between 0.1 and 0.4 (fig. 15). A specific yield of 0.1 results in a volume of water of about 240,000 acre-ft; a specific yield of 0.4 , which is an extremely high value, results in a volume of water of about 960,000 acre-ft. The specific-yield value used in the ground-water model developed by Reclamation was 0.34 , which gives a value of about 800,000 acre-ft. 


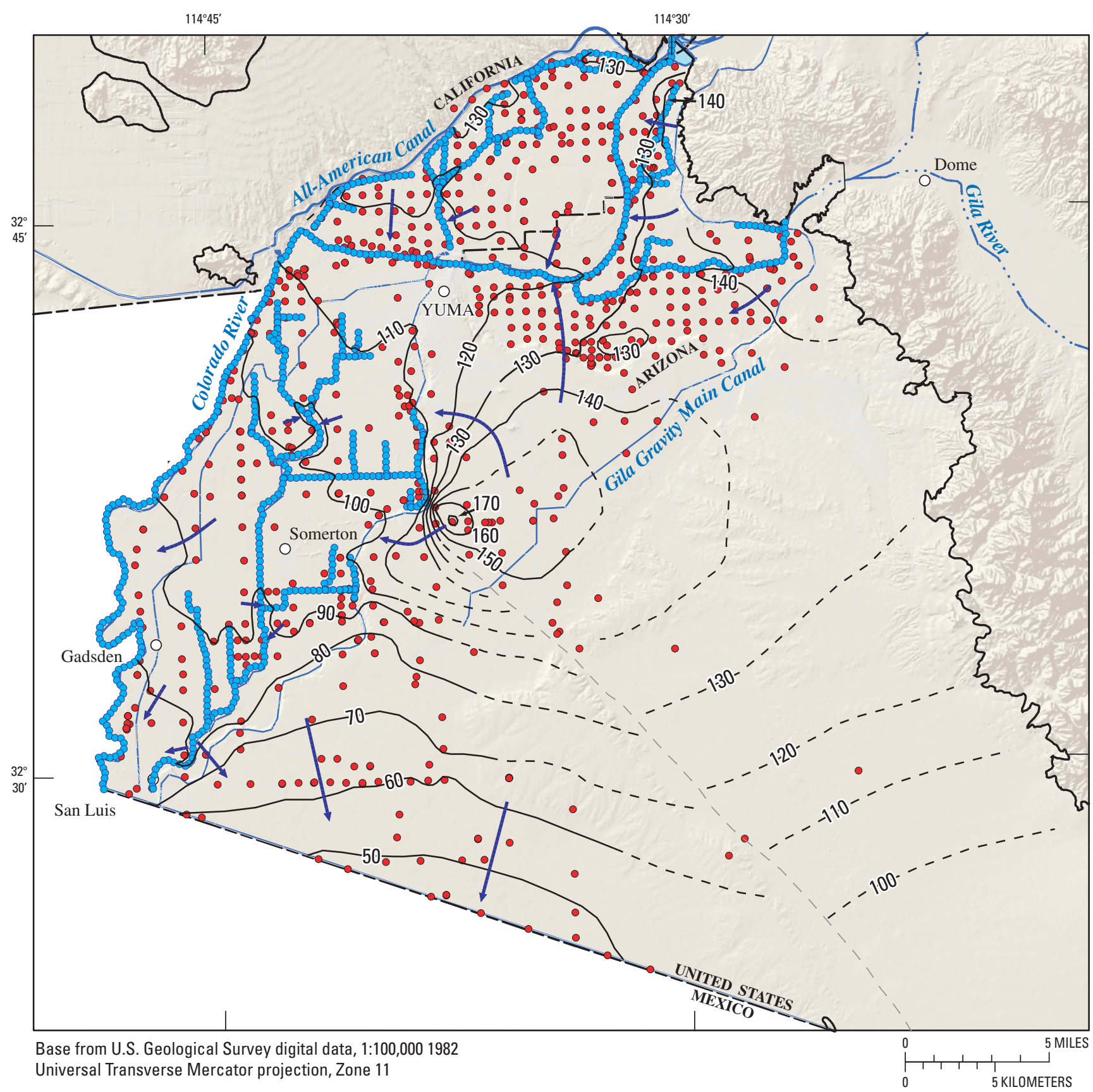

EXPLANATION

\begin{tabular}{|c|c|}
\hline & $\begin{array}{l}\text { Water-level contour-Shows equal elevation of water levels representing the water table. Contoured } \\
\text { east of the Colorado River and south of the All American Canal. Dashed where estimated. } \\
\text { Interval } 10 \text { feet. Datum is NGVD of } 1929\end{array}$ \\
\hline- & Approximate location of the Algodones Fault \\
\hline & Aquifer boundary —Approximate limit of the aquifer modfied from Owen-Joyce and others (2000) \\
\hline - & Well having water-level elevation data \\
\hline - & Site having estimated surface-water elevation \\
\hline
\end{tabular}

Figure 14. Wells having water-level measurements, surface-water elevations that are likely hydraulically connected to ground water, water-table contours, and generalized ground-water flow directions 2004-2005. 


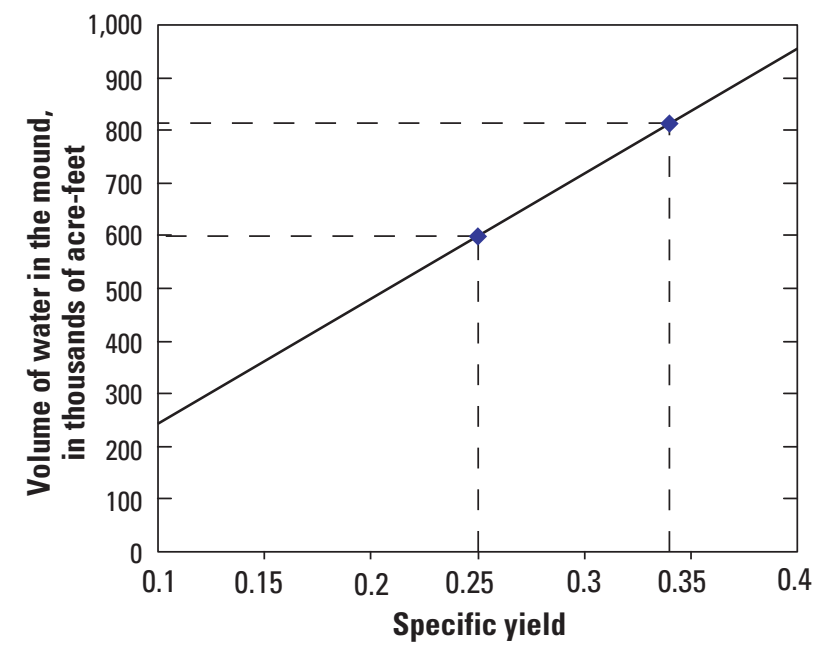

Figure 15. Relationship between the specific yield of subsurface sediments in the Yuma mound area and the amount of ground water stored in the mound. A specific yield of 0.34 , which is the value used within Reclamation's ground-water flow model, yields a volume of about 800,000 acre-ft of stored ground water. A specific yield of 0.25 , which assumes that water is retained in void spaces between grains during the drainage process, yields a volume of 600,000 acre-ft of stored ground water.

Olmsted and others (1973), however, noted that the amount of water drained from irrigated areas already having residual water content between grains of sediment would have a lower value of specific yield. A specific-yield value of 0.25 , which assumes that water is retained in the void spaces between grains during the drainage process, results in a total volume of about 600,000 acre-ft. These estimates of ground water stored in the mound, however, are based on a somewhat arbitrary assignment of the extent of the mound and with limited information about the spatial distribution of values of specific yield. The extent covers the areas having the greatest increases in ground-water levels, so incorporating a larger area would not significantly increase the estimate of stored water.

Analyses of ground-water levels for 2004-2005 are useful for understanding recent changes in general groundwater flow. Current water levels are important calibration data for ground-water models used to simulate possible effects of water-management practices. Ground-water levels also provide important information about the general directions of ground-water flow. Contours of ground-water levels along the Colorado River and Gila River suggest that the river channels are ground-water sinks. Changes in water levels in the Yuma mound were used to estimate the amount of stored ground water that can be developed.

\section{Water Chemistry at Selected Sites in Yuma Valley, South Gila Valley, and Yuma Mesa}

\section{Summary and Analyses of Existing Data}

Available ground-water quality data collected by Reclamation and by the USGS were compiled for the study area. The USGS NWIS database

(http://waterdata.usgs.gov/usgs.nwis/si, accessed March 10, 2005) contains more than 2,700 recorded ground-water sites in the study area. Among the water-quality records, 997 records for water quality were listed for these sites: 238 sites were sampled once and 182 sites were sampled more than once. These samples include measurements of physical parameters, major and minor ions, nutrients, trace elements, and isotopes. Reclamation provided historical water-quality data for 68 drainage or regulatory wells under its operation. More than 530 records were available for the 1984-2005 period. These records include measurements of major and minor ions, nutrients, and physical parameters. Both waterquality data sets were merged into a single database. This water-quality information, along with site-location and wellconstruction information, was incorporated into a GIS project for spatial analysis.

Historical major-ion data for ground-water samples from drainage wells operated by Reclamation are summarized according to geographic location in figure 16. The trilinear diagram presents the relative contribution of major cations and anions by expressing each concentration (on a chargeequivalent basis) as a percentage of the total-ion content of the water. This type of diagram is useful for screening a large number of chemical analyses, identifying simple groundwater mixing between chemically distinct sources, and distinguishing water-mineral interactions along a ground-water flow path.

In this report, the dominant cation and anion species are used to describe the chemical character-or hydrochemical facies - of a water sample. Where no one species exceeds 50 percent, the first and second most abundant ions are given for description purposes. Of the samples considered, $469 \mathrm{had}$ an ion balance difference (cations to anions) of less than 5 percent; 23 samples were between 5 and 10 percent.

Water from selected wells in the study area had a chemical composition that ranged from calcium/sodium-mixed anion to sodium/calcium-sulfate/chloride to sodium-chloride (fig. 16). Spatially, this range of compositions generally is not exclusive to one part of the study area, however, variations within a particular geographic location do exist. For example, moving from west to east along the wells in the 242-Wellfield east of San Luis (fig. 17), the chemical composition of water gradually changes from sodium/calcium-chloride/sulfate to sodium-chloride type. 


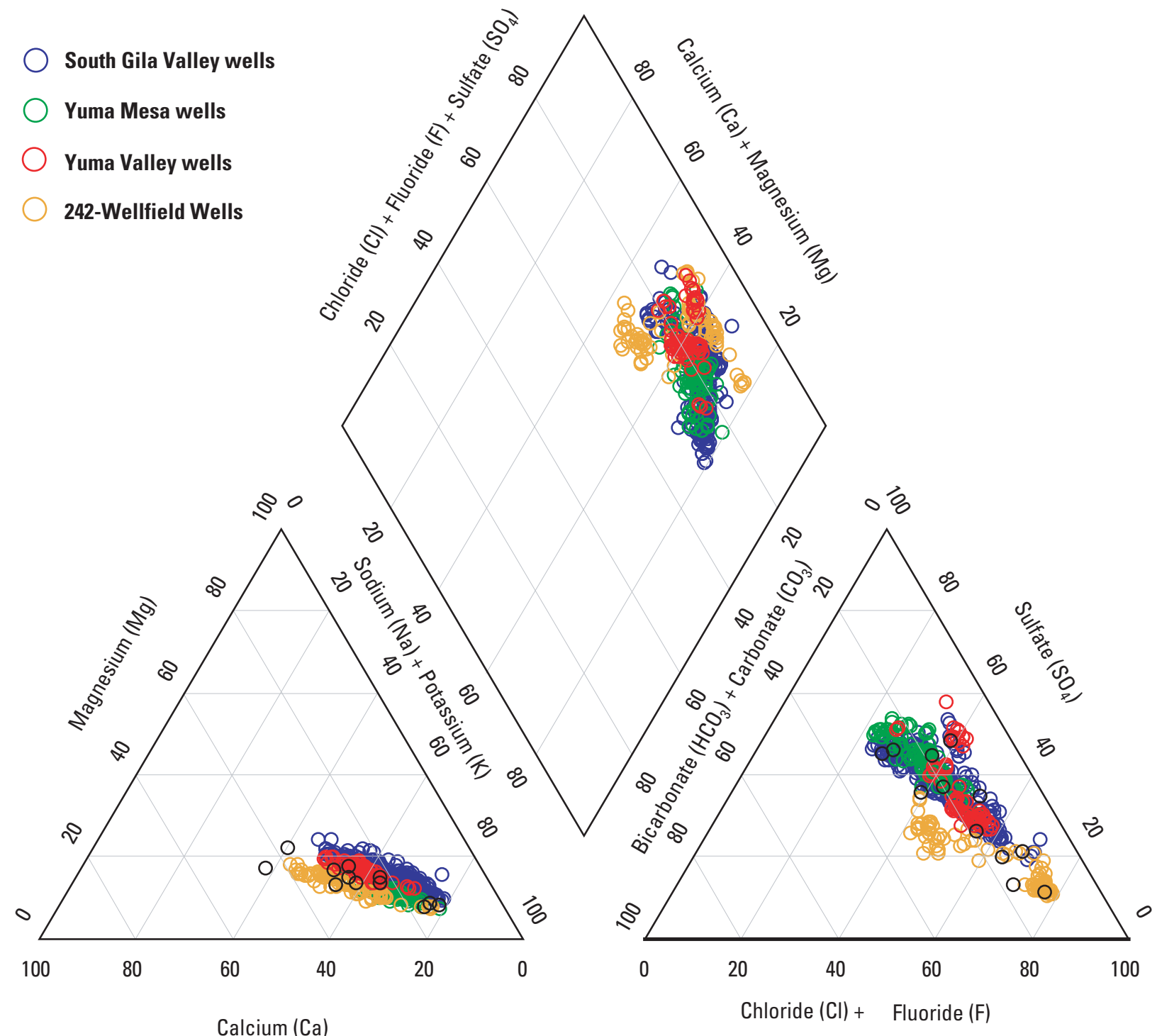

Figure 16. Trilinear diagram showing major-ion composition of ground water from selected wells in the Yuma area, 1984-2005. 


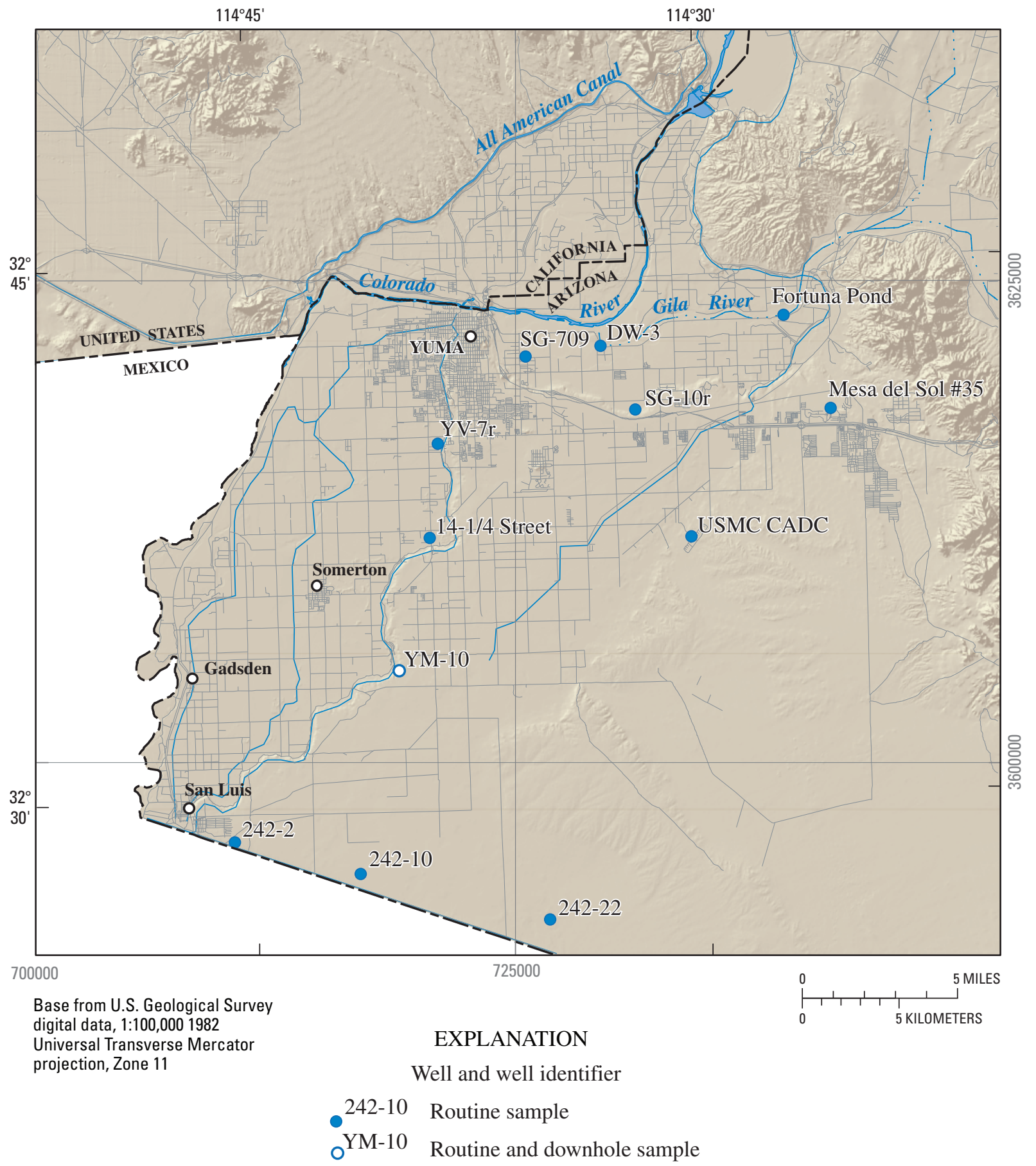

Figure 17. Locations of wells sampled, April-September 2005. 
To examine temporal trends in water quality, time-series plots of historical data were constructed (Appendix C) for selected wells. The following parameters were chosen for review: temperature, $\mathrm{pH}$, dissolved solids, chloride, sulfate, and nitrate. Near the SIB, there is a trend of increasing dissolved-solids, chloride, and sulfate concentrations for western (242-2) and central (242-10) wells along the alignment of the wells in the 242-Wellfield; farther east at well 242-22, the six parameters were relatively unchanged.

\section{New Water-Quality Data}

A component of this study was the collection of new water-quality data. Details of the sample-collection procedures and laboratory analyses are described in the following section. Inorganic water chemistry, stable isotope, tritium $\left({ }^{3} \mathrm{H}\right)$, and carbon-14 $\left({ }^{14} \mathrm{C}\right)$ results also are presented and discussed.

\section{Sample Collection}

Samples were collected during April and September 2005 from 12 ground-water wells, and 8 canals or drains. At ground-water site YM-10, three depth-dependent samples were collected from discrete depths within the well casing (see "Wellbore Velocity Profile and Depth-Dependent Sampling" section for details). Figure 17 shows the location of these sampling sites. Site and construction information for sampling locations is presented in table 3. Most wells have perforations that are open to the coarse-gravel unit and (or) wedge zone (table 1).

Sampling was conducted by USGS personnel, and all samples were collected, handled, and preserved following procedures in the USGS National Field Manual (http://water.usgs.gov/owq/FieldManual/, accessed March 21, 2005). Ground-water samples were collected from a spigot near the well head and upstream of any chemical treatment.

Each well was pumped for a minimum of 30 minutes prior to sampling to purge at least three casing-volumes of water. Specific conductance, $\mathrm{pH}$, dissolved oxygen, temperature, and oxidation-reduction potential were monitored during this period by using a multi-parameter sonde and flow-through chamber. Samples were collected only after the required time and when three successive measurements taken at intervals of 5 minutes or more differed by less than 5 percent for specific conductance $(0.1$ units for $\mathrm{pH}, 0.3 \mathrm{mg} / \mathrm{L}$ for dissolved oxygen, and $0.2^{\circ} \mathrm{C}$ for temperature. Waterquality meters were calibrated daily and verified throughout the day.

Table 3. Location, construction, and hydrogeologic information for ground-water wells sampled.

\begin{tabular}{|c|c|c|c|c|c|c|}
\hline USGS site name & $\begin{array}{l}\text { Common } \\
\text { site name }\end{array}$ & $\begin{array}{c}\text { Altitude of } \\
\text { land surface } \\
\text { (feet) }\end{array}$ & $\begin{array}{c}\text { Depth to bottom } \\
\text { of casing } \\
\text { (feet below } \\
\text { land surface) }\end{array}$ & $\begin{array}{c}\text { Diameter } \\
\text { of casing, } \\
\text { (inches) }\end{array}$ & $\begin{array}{l}\text { Perforated } \\
\text { intervals } \\
\text { (feet below } \\
\text { land surface) }\end{array}$ & Hydrogeologic unit \\
\hline C-08-21 19ACC & Fortuna Pond & 160 & 225 & & $85-225$ & Coarse-gravel unit, undifferentiated lower units \\
\hline C-08-22 30ABD1 & DW-3 & 135 & 166 & 16 & $105-162$ & Coarse-gravel unit, undifferentiated lower units \\
\hline C-09-22 04BCC2 & Mesa del Sol \#35 & 289 & 795 & 16 & $485-785$ & Undifferentiated lower units \\
\hline C-09-22 05ACA & SG-10r & 146 & 184 & 16 & $\begin{array}{c}87-129, \\
148-150, \\
164-184\end{array}$ & $\begin{array}{l}\text { Middle fill, coarse-gravel unit, undifferentiated } \\
\text { lower units }\end{array}$ \\
\hline C-09-22 27BDD2 & USMC CADC & 245 & 258 & 6 & $158-258$ & Coarse-gravel unit \\
\hline C-09-23 29BBC3 & 14-1/4 Street & 114 & 220 & 24 & $145-208$ & Undifferentiated lower units \\
\hline C-10-24 13ADD2 & YM-10 & 173 & 220 & 16 & $153-220$ & Coarse-gravel zone, undifferentiated lower units \\
\hline C-11-23 26DBB & $242-22$ & 170 & 637 & 12 & $\begin{array}{l}208-308 \\
330-631\end{array}$ & Undifferentiated lower units \\
\hline C-11-24 07DCC2 & $242-2$ & 145 & 551 & 12 & $\begin{array}{l}243-329 \\
331-546\end{array}$ & Undifferentiated lower units \\
\hline C-11-24 23ABB & $242-10$ & 162 & 672 & 12 & $\begin{array}{l}268-358 \\
360-666\end{array}$ & Undifferentiated lower units \\
\hline
\end{tabular}


Unfiltered water was collected for the analysis of stable isotopes (15-mL glass vial) and ${ }^{3} \mathrm{H}$ (1-L polyethylene). Both of these bottles were sealed tightly with a polyseal (conical) cap to minimize exchange with the atmosphere. A $0.45-\mu \mathrm{m}$ polyethersulfone capsule filter was used to filter water for the trace elements $(250-\mathrm{mL}$ polyethylene), major ions $(250-\mathrm{mL}$ polyethylene), nutrients (125-mL dark polyethylene), and ${ }^{14} \mathrm{C}$ (500-mL amber glass with polyseal cap). Nitric acid was added to samples for trace-element analysis to lower the $\mathrm{pH}$ to 2 or less. Nutrient and ${ }^{14} \mathrm{C}$ samples were placed and shipped on ice.

Alkalinity was determined on a filtered sample by incremental titration immediately following collection. A sniff test for the presence/absence of sulfide was conducted during sample collection. Dissolved oxygen-because of relatively low concentrations - was determined by titration in the field by using an Alsterberg-Azide modification to the Winkler titration procedure outlined by Radtke and others (1998).

At each surface-water site, a grab sample of water (unfiltered) was collected for the analysis of specific conductance, $\mathrm{pH}$, temperature, anions, and stable isotopes. Anions (chloride, bromide, sulfate, orthophosphate, nitrite, and nitrate) were measured at the USGS San Diego Laboratory by using an ion chromatograph.

\section{Sample Analysis}

Most samples were analyzed at the USGS National Water-Quality Laboratory (NWQL) in Denver, Colorado, following standard methods described by Faires (1993), Fishman (1993), Fishman and Friedman (1989), Struzeski and others (1996), or the American Public Health Association (1998). Results are shown in table 4.

Stable isotope samples were analyzed at the USGS Stable Isotope Laboratory in Reston, Virginia, by using a hydrogen equilibration technique (Revesz and Coplen, U.S. Geological Survey, written commun., 2003a), and carbon dioxide equilibration technique (Revesz and Coplen, U.S. Geological Survey, written commun., 2003b). Stable isotope values are expressed as ratios (denoted 'per mil') relative to Vienna Standard Mean Ocean Water (VSMOW) and normalized (Coplen, 1994) on scales such that the oxygen and hydrogen isotopic values of Standard Light Antarctic Precipitation (SLAP) are -55.5 per mil and -428 per mil, respectively (table 5). The estimates of precision (two standard deviations) for oxygen and hydrogen stable isotope measurements are 0.2 per mil and 2 per mil, respectively.

Tritium samples were analyzed at the University of Miami Tritium Laboratory by an electrolytic enrichment and gas-counting technique (Ostlund and Dorsey, 1977; Ostlund and others, 1987). The activity of ${ }^{3} \mathrm{H}$ and estimate of precision (two standard deviations) is reported in terms of tritium units (TU) in table 6. One TU equals one atom of ${ }^{3} \mathrm{H}$ in 1018 atoms of hydrogen.

$\mathrm{C}^{13} / \mathrm{C}^{12}$ ratio and ${ }^{14} \mathrm{C}$ activity of dissolved inorganic carbon were analyzed at the University of Waterloo (Ontario, Canada) and The University of Arizona (Tucson, Arizona), respectively, by accelerator mass spectrometry (Donahue and others, 1990; Jull and others, 2004). Results of the $\mathrm{C}^{13} / \mathrm{C}^{12}$ determination are reported in per mil relative to the Vienna PeeDee belemnite standard (Coplen, 1994). ${ }^{14} \mathrm{C}$ data are expressed as percent modern carbon (pmc) by comparing ${ }^{14} \mathrm{C}$ activities with the specific activity of an oxalic acid standard prepared by the National Bureau of Standards (Mook and van der Plicht, 1999). Results of these measurements are presented in table 6 .

\section{Wellbore Velocity Profile and Depth-Dependent Sampling}

To improve the understanding of the 3D geochemistry of the aquifer system, specialized sampling techniques were used to collect discrete water-quality samples from different depths within a single well. On the basis of availability, access, and construction, well YM-10 was selected for this evaluation. Before collecting discrete water-quality samples, a velocity profile was constructed by using a tracer-pulse (dye-injection) method (Izbicki and others, 1999) to provide information on the amount of water entering the well from different depths. Nine injection tests were performed at depths ranging from 150 to $210 \mathrm{ft}$ below land surface. Discrete water-quality samples then were collected at $154 \mathrm{ft}, 174 \mathrm{ft}$, and $194 \mathrm{ft}$ below land surface under pumping conditions by using a tool described by Izbicki (2004). Well velocity (or flow) data, when combined with depth-dependent water-chemistry data, provide insight into how waters are extracted from different parts of the aquifer system and provide an explanation for (composite) water-quality conditions at the well head. Results of the test at well YM-10 are discussed in the "Source and Movement of Ground Water in the Study Area" section.

\section{Inorganic Water Chemistry}

Dissolved-solids concentrations, commonly referred to as total dissolved solids (TDS), ranged from 801 to $3,020 \mathrm{mg} / \mathrm{L}$ (fig. 18) for wells sampled in the study area. In general, TDS values were greater in water from wells in South Gila Valley and near the edge of Yuma Mesa, and lower at locations farther up Yuma Mesa. Most TDS values were comparable to historic concentrations, except the Fortuna Pond well, at which TDS has increased steadily from about $1,500 \mathrm{mg} / \mathrm{L}$ in 1999 to about 2,200 mg/L in 2005.

Nitrate (as nitrogen) concentrations ranged from less than the detection limit $(<0.06)$ to $8.0 \mathrm{mg} / \mathrm{L}$ in water from wells sampled in the study area (fig. 18). Elevated nitrate concentrations in ground water, which may result from the application of fertilizer and irrigation (Olmsted and others, 1973), are present in wells near and in Yuma Mesa (SG-10r, CADC, 14-1/4 Street, YM-10). Other wells in proximity to Yuma Mesa, however, yielded water having very low nitrate concentrations or nitrate concentrations less than the detection limit (Fortuna Pond, SG-709, YV-7r). 

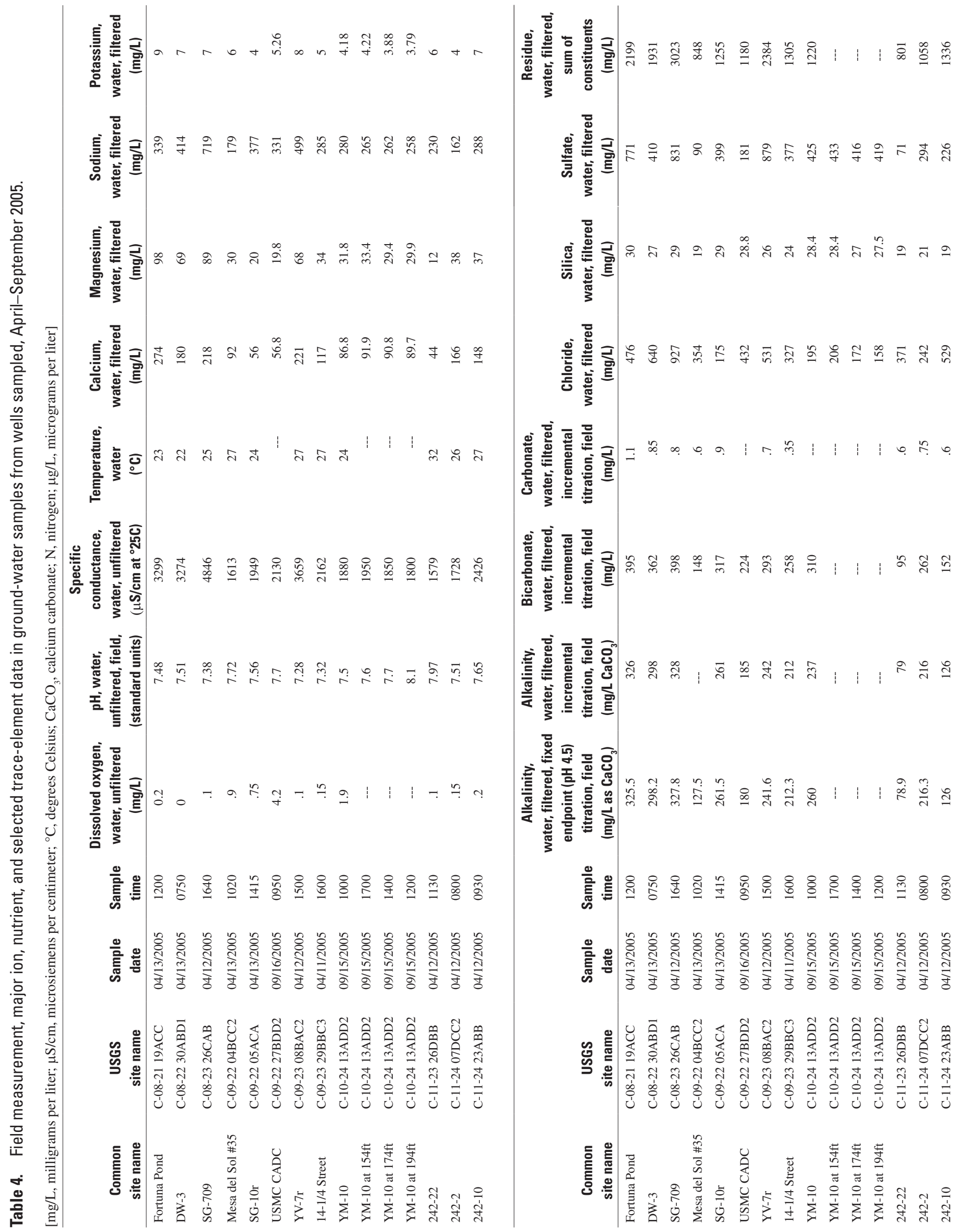


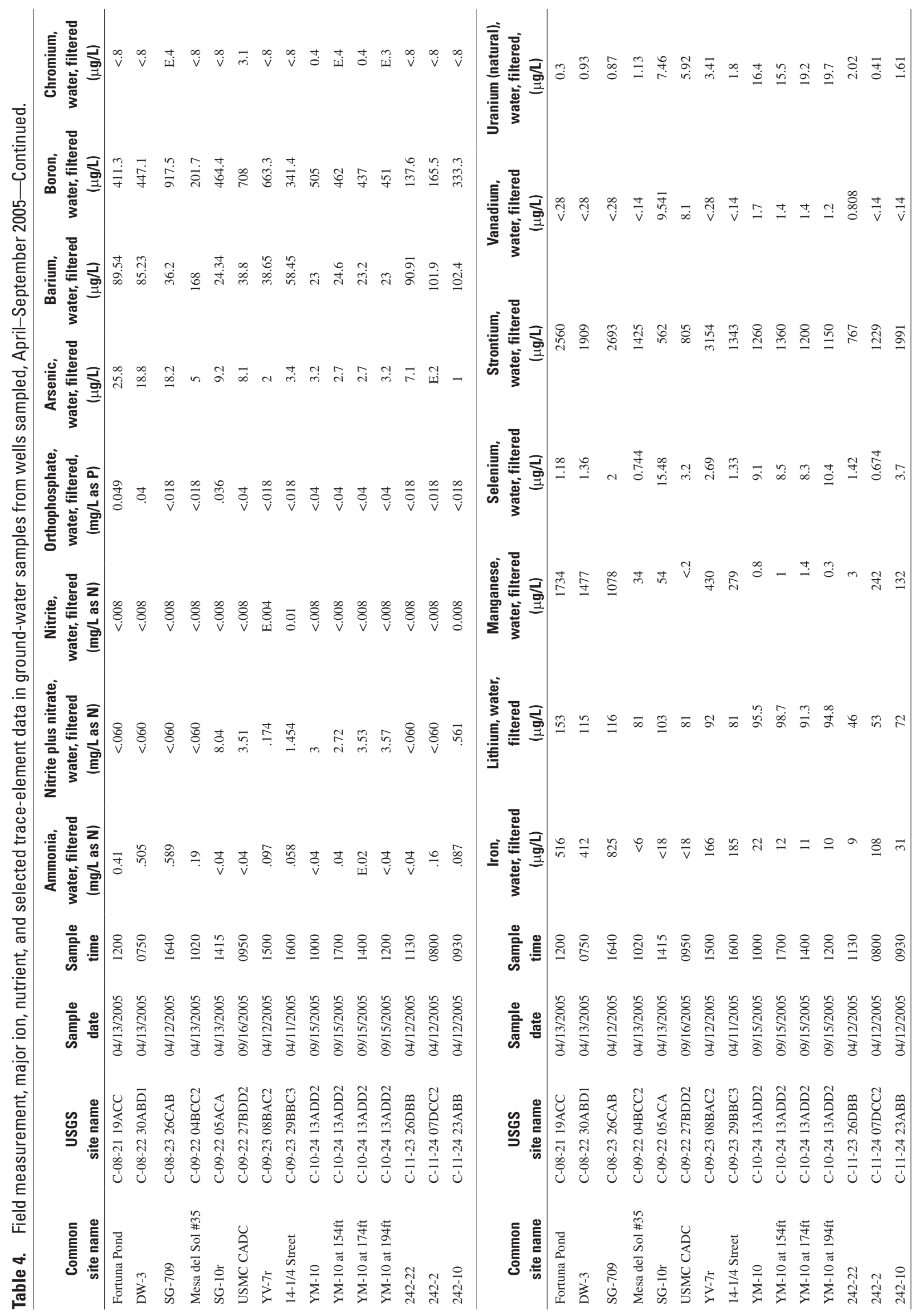


Table 5. Field measurement, selected anion, deuterium, and oxygen-18 data in surface-water samples collected April 2005.

$\left[{ }^{\circ} \mathrm{C}\right.$, degrees Celsius; mg/L, milligrams per liter; $\mathrm{N}$, nitrogen; P, phosphorus; \%o, per mil]

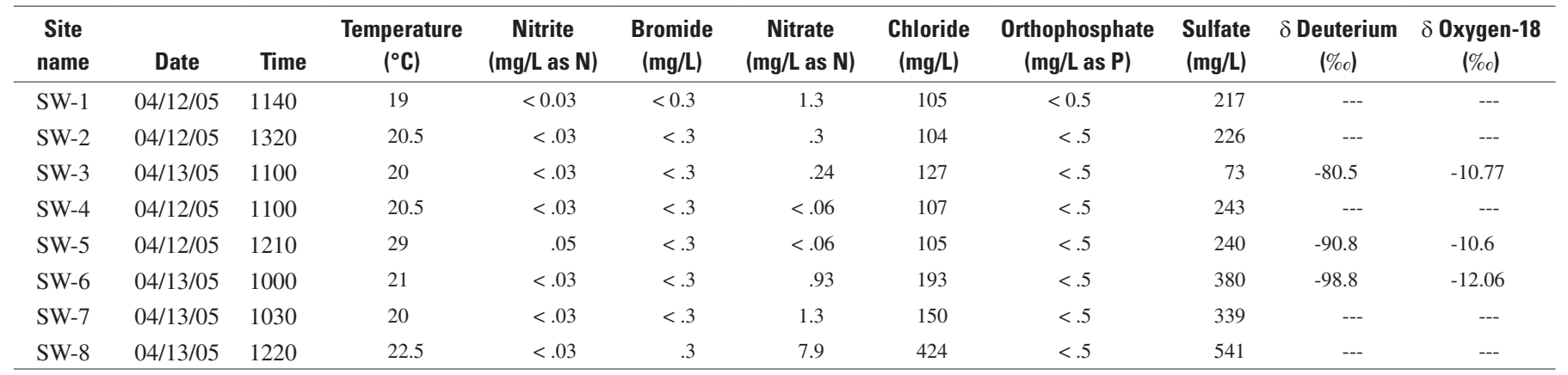

Table 6. Deuterium, oxygen-18, tritium, carbon-13, and carbon-14 data in ground-water samples from wells sampled, April-September 2005.

[\%o, per mil; TU, tritium unit; C, carbon; pmc, percent modern carbon]

\begin{tabular}{|c|c|c|c|c|c|c|c|c|c|}
\hline State well number & Common name & $\begin{array}{c}\text { Sample } \\
\text { date }\end{array}$ & $\begin{array}{c}\delta \text { Deuterium } \\
(\% o)\end{array}$ & $\begin{array}{c}\delta \text { Oxygen-18 } \\
(\%)\end{array}$ & $\begin{array}{c}\text { Deuterium } \\
\text { residual } \\
(\% \circ) \\
\end{array}$ & $\begin{array}{c}\text { Tritium } \\
\text { (TU) }\end{array}$ & $\begin{array}{c}\text { Tritium, } \\
\text { 2-sigma error } \\
\text { (TU) }\end{array}$ & $\begin{array}{c}\mathbf{C}^{13} / \mathbf{C}^{12} \\
(\%)\end{array}$ & $\begin{array}{c}{ }^{14} \mathrm{C} \\
\text { (pmc) }\end{array}$ \\
\hline C-08-21 19ACC & Fortuna Pond & $04 / 13 / 05$ & -95 & -11.5 & -13 & 18 & 1.2 & -14 & 110 \\
\hline C-08-23 26CAB & SG-709 & $04 / 12 / 05$ & -86 & -10.6 & -12 & 16 & 1 & --- & --- \\
\hline C-09-22 04BCC2 & Mesa del Sol \#35 & $04 / 13 / 05$ & -67 & -8.5 & -9 & 2 & 0.2 & --- & --- \\
\hline C-09-23 08BAC2 & YV-7r & $04 / 12 / 05$ & -90 & -11.1 & -11 & 14 & 0.8 & -9 & 70 \\
\hline C-09-23 29BBC 3 & 14-1/4 Street & $04 / 11 / 05$ & -84 & -10.5 & -10 & 10 & 0.6 & --- & -- \\
\hline C-10-24 13ADD2 & YM-10 & $09 / 15 / 05$ & -97.4 & -11.8 & -13 & 14.1 & 1 & --- & --- \\
\hline C-10-24 13ADD2 & $\mathrm{YM}-10$ at $154 \mathrm{ft}$ & 09/15/05 & -97.2 & -11.8 & -13 & 15.9 & 1 & --- & --- \\
\hline C-10-24 13ADD2 & YM-10 at $174 \mathrm{ft}$ & 09/15/05 & -96.5 & -11.8 & -12 & 16.1 & 1 & --- & --- \\
\hline C-11-24 23ABB & $242-10$ & $04 / 12 / 05$ & -101 & -13 & -7 & $<.1$ & 0.2 & -11 & 59 \\
\hline
\end{tabular}

Arsenic was detected in all 12 wells sampled at concentrations ranging from 0.2 to $26 \mu \mathrm{g} / \mathrm{L}$. In 2006, the U.S. Environmental Protection Agency's Maximum Contaminant Level (MCL) for arsenic decreased from 50 to $10 \mu \mathrm{g} / \mathrm{L}$. Water from three wells with concentrations greater than the MCL occur in South Gila Valley. Four other wells in the study area had arsenic concentrations greater than one-half the MCL. The median concentration of arsenic measured in surface water from the Gila River between 1972 and 1995 was about $10 \mu \mathrm{g} / \mathrm{L}$ (http://waterdata.usgs.gov/az/nwis, accessed December 1, 2005).

The general chemical character of water from wells sampled in the study area is summarized in figure 19. The compositions range from a calcium/sodium-mixed anion to sodium/calcium-sulfate/chloride to sodium-chloride type. Figure 19 also shows that the median chemical composition of surface water collected at the Colorado River (USGS 09429600) and Gila River (USGS 09520700) for the period 1972-1995 is inclusive of this range. With the exception of water collected from the Fortuna Pond well, the composition of water collected for this study was comparable to historic compositions (fig. 16). One well that is readily distinguished from others is SG-10r. The chemical composition of water from this well is primarily sodium and sulfate ions. Water from this well also was relatively high (in comparison to other wells sampled) in arsenic $(9.2 \mu \mathrm{g} / \mathrm{L})$, selenium $(15.5 \mu \mathrm{g} / \mathrm{L})$, vanadium $(9.5 \mu \mathrm{g} / \mathrm{L})$, and uranium $(7.5 \mu \mathrm{g} / \mathrm{L})$. This is the only well sampled that has perforations open to the middle fill unit.

\section{Stable Isotopes}

Stable isotopes are useful for identifying different sources of ground-water recharge and possibly distinguishing between waters with a similar chemical composition. The stable isotopes of oxygen-18 $\left({ }^{18} \mathrm{O}\right)$ and deuterium [hydrogen-2 $\left({ }^{2} \mathrm{H}\right.$ or D)] are heavier than the common forms of oxygen [oxygen-16 or ${ }^{16} \mathrm{O}$ ) and hydrogen (hydrogen- 1 or ${ }^{1} \mathrm{H}$ ). 


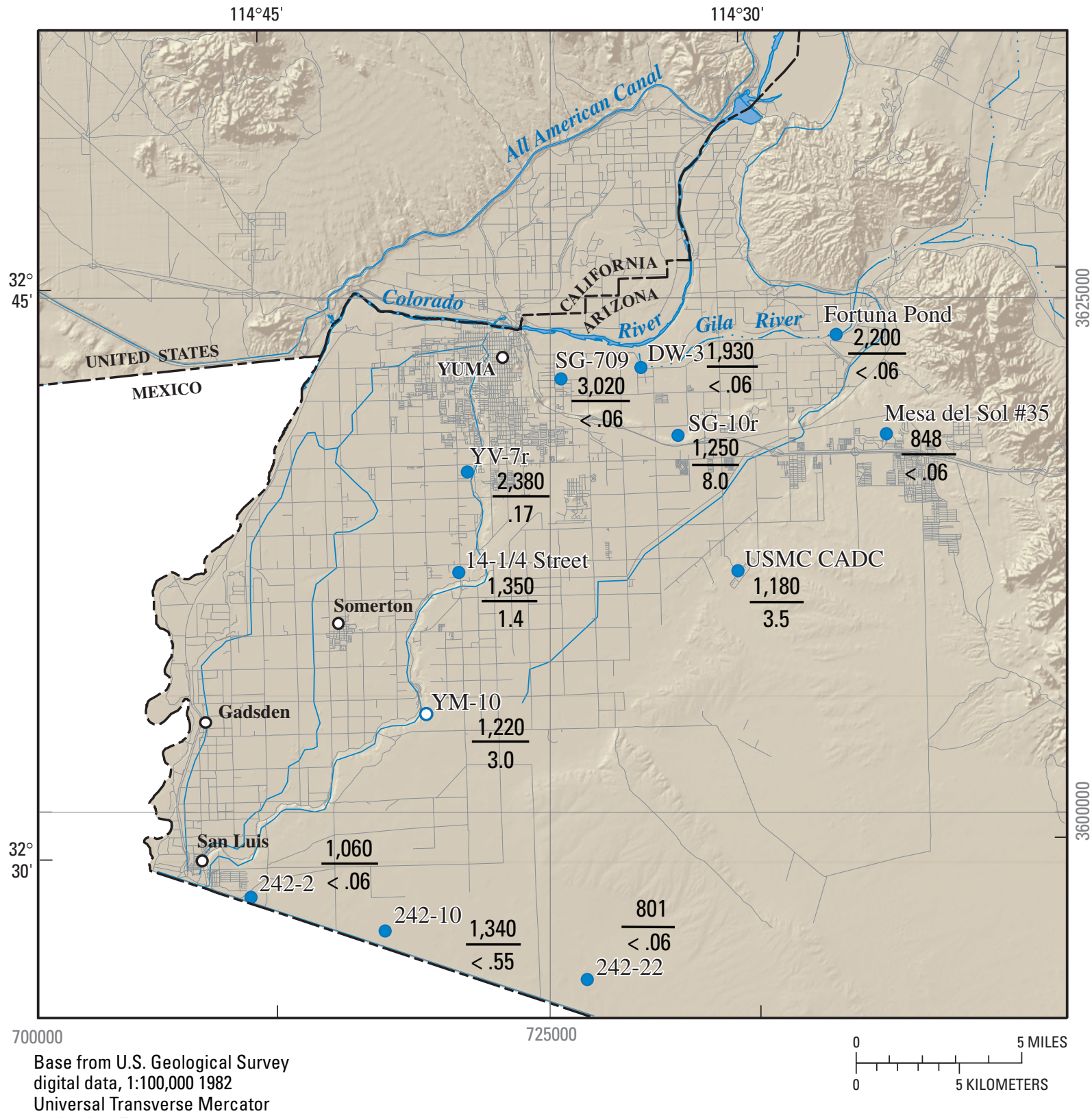

Universal Transverse Mercator projection, Zone 11

\section{EXPLANATION}

Well and well identifier

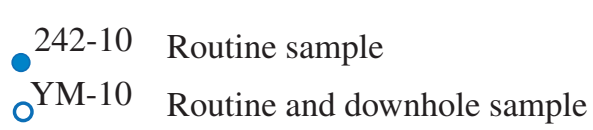

Dissolved-solids concentration,

1,340 in milligrams per liter

.56 Nitrate concentration, in milligrams per liter (as nitrogen)

Figure 18. Dissolved solids and nitrate (as N) concentrations for wells sampled, April-September 2005. 
O $^{\text {A Well-water samples }}$

$\begin{array}{ll}\text { A } & \text { Fortuna Pond } \\ \text { B } & \text { DW-3 } \\ \text { C } & \text { SG-709 } \\ \text { D } & \text { Mesa del Sol \#35 } \\ \text { E } & \text { SG-10r } \\ \text { F } & \text { USMC CADC } \\ \text { G } & \text { YV-7r } \\ \text { H } & 14-1 / 4 \text { Street } \\ \text { I } & \text { YM-10 } \\ \text { J } & 242-22 \\ \text { K } & 242-2 \\ \text { L } & 242-10\end{array}$

L $242-10 \quad 50$

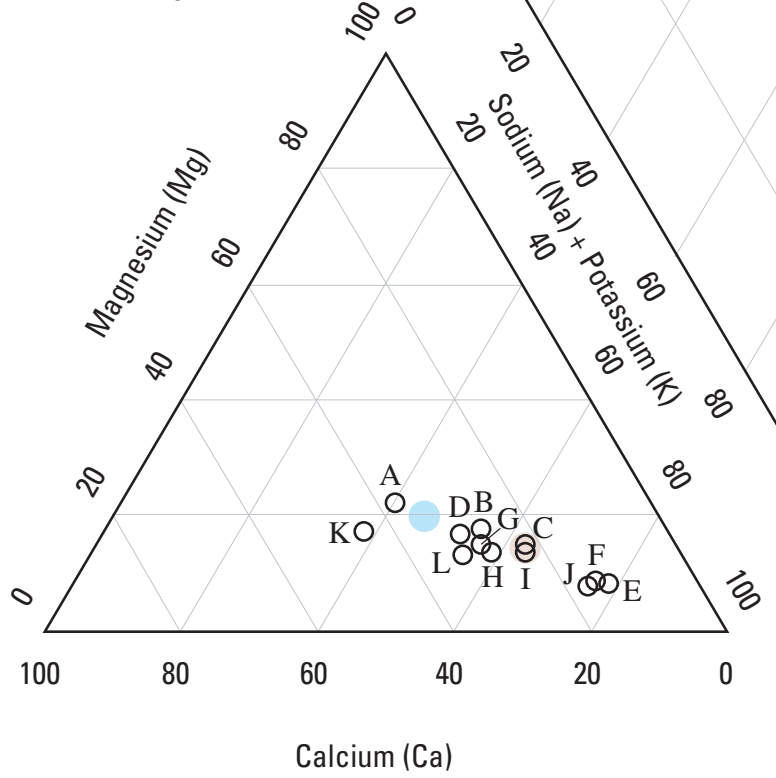

Surface-water samples

Colorado River

Gila River

Figure 19. Trilinear diagram showing major-ion composition of ground water from sampled wells and surface water from two locations in the study area, April-September 2005.

Stable isotopes are an ideal tracer of water because they are part of the water molecule and do not react like other tracers. The relative abundance of these isotopes in water is affected by several factors.

Precipitation originating as evaporation from seawater will have an isotopic composition that is correlated linearly along the global meteoric water line (Rosanski and others, 1993) (fig. 20). Precipitation condensing at higher elevations or at cooler temperatures will have a relatively light (more negative) isotopic composition; and at lower elevations or at warmer temperatures, the isotopic composition will be relatively heavy (less negative). Water that has been affected by evaporation - such as irrigation-will show greater depletion in D, relative to ${ }^{18} \mathrm{O}$ (Schroeder and others, 1991). The isotopic composition of water, once in the aquifer, does not readily change, except possibly by mixing with another isotopically distinct source.
Ratios of heavier to lighter isotopes are reported as deviations from an international standard, Satandard Mean Ocean Water (SMOW). Values are expressed in parts per thousand or per mil (\%o) using delta notation:

$$
\delta=\left(\frac{R x-R s t d}{R s t d}\right) 1,000,
$$

where

$$
\begin{aligned}
\delta & =\text { delta notation, } \\
R x & =\text { ration of isotopes measured in sample, and } \\
R s t d & =\text { ratio of same isotopes in the standard (VSMOW). }
\end{aligned}
$$




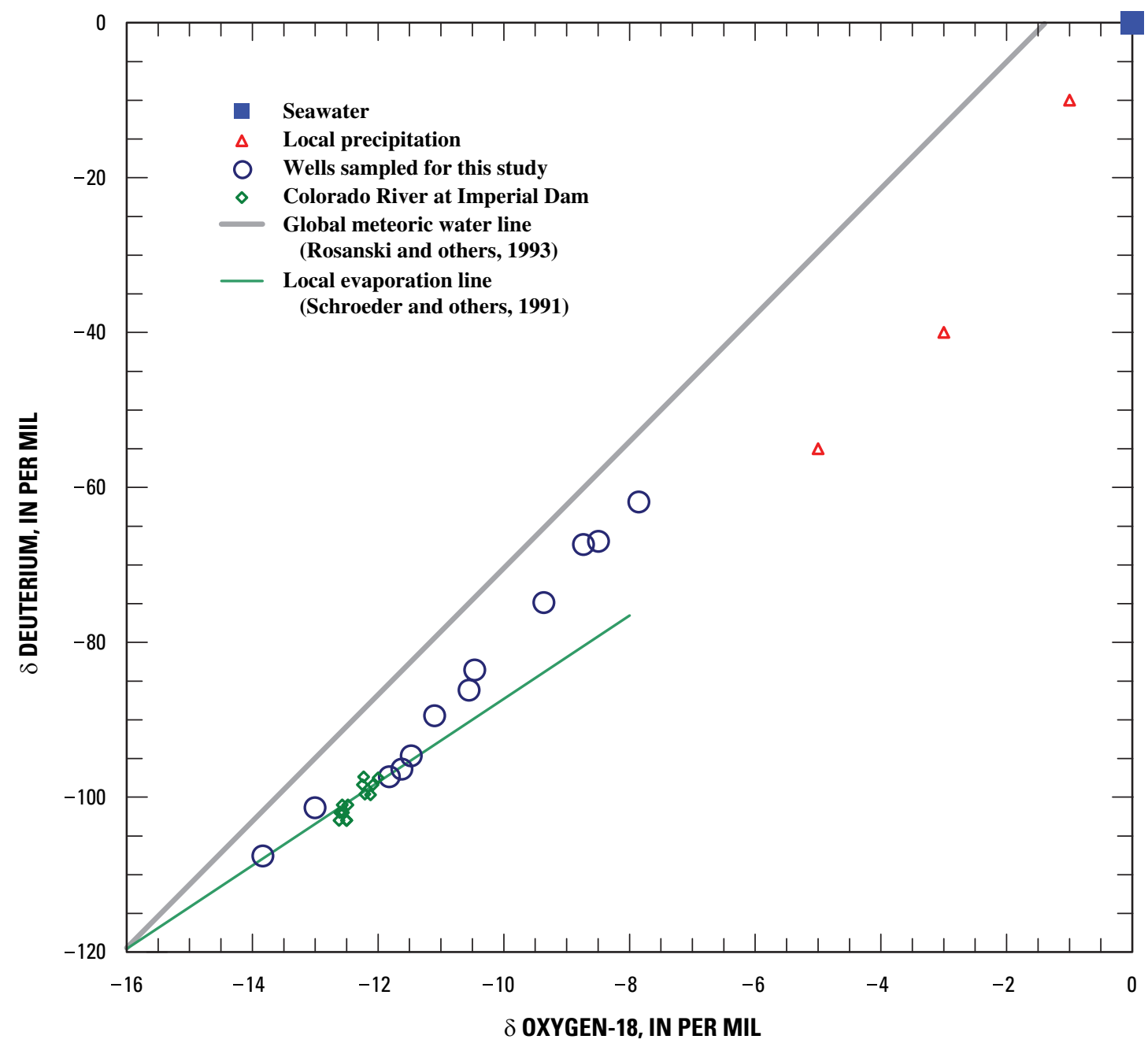

Figure 20. $\delta$ deuterium as a function of $\delta$ oxygen-18 in ground water sampled (and other sources) in the study area.

Stable isotope data for wells sampled as part of this study, Colorado River water at the Imperial Dam, local precipitation, and seawater are shown in figure $20 .{ }^{18} \mathrm{O}$ values in water from newly sampled wells range from -13.8 to -7.8 per mil. The lightest (most negative) value is from water in well 242-2, in the southwestern part of the study area near the Colorado River. Recharge to this well is likely derived entirely from the Colorado River and has a composition similar to water upstream at Imperial Dam. The heaviest (least negative) value is from water in well 242-22, in the south-central portion of the study area far away from the Colorado River. As shown by data from several precipitation stations in the study area (fig. 20), recharge to well 242-22, and to USMC CADC and Mesa del Sol \#35 ( -8.6 per mil) is attributed to local recharge originating from the Upper Mesa and adjacent hills. Recharge to other wells having an intermediate isotopic composition can be explained by evaporation of water prior to recharge, or by a binary mixture of the two end members just described. For example, values for water from wells SG-10r, YM-10, and Fortuna Pond plot below the meteoric water line and along a local evaporation line (Schroeder and others, 1991) and are consistent with the diversion, application, and return of Colorado River water used for irrigation. These wells also have the greatest D residual - the amount by which a particular composition plots below the global meteoric water line-as shown in table 6. In contrast, well DW-3 has a relatively smaller $\mathrm{D}$ residual and does not plot along the evaporation line. On the basis of ${ }^{18} \mathrm{O}$ data, the isotopic composition of water from well DW-3 could result from a mixture of about 75 percent local water and about 25 percent Colorado River water.

Additional stable isotopic data would be helpful to better define the signature and extent of locally recharged ground water across Yuma Mesa. Likewise, additional isotopic data from Yuma Valley and Yuma Mesa are needed to better characterize the occurrence of modern Colorado River water. This new information also would be useful for verifying the exact source of several intermediate values. 


\section{Radioisotopes: ${ }^{3} \mathrm{H}$ and ${ }^{14} \mathrm{C}$}

To distinguish water that was recharged relatively recently from older water, samples were analyzed for ${ }^{3} \mathrm{H}$ content. ${ }^{3} \mathrm{H}$ is a naturally occurring radioisotope of hydrogen that decays (half-life of 12.4 years) by beta-particle emission into helium-3 $\left({ }^{3} \mathrm{He}\right)$. Because ${ }^{3} \mathrm{H}$ is part of the water molecule and is not affected by reactions other than radioactive decay, it serves as a useful natural tracer for identifying recently recharged water (Michel, 1989). The concentration of ${ }^{3} \mathrm{H}$ is presented in TU; 1 TU equals $3.2 \mathrm{pCi} / \mathrm{L}$.

Prior to 1950 , the ${ }^{3} \mathrm{H}$ concentration of precipitation in Imperial Valley was approximately 2-3 TU, and 5-6 TU in Colorado River water (Michel and Schroeder, 1994). Beginning in 1952, significant quantities of ${ }^{3} \mathrm{H}$ were released into the atmosphere from the testing of hydrogen bombs, reaching a maximum in surface water collected from the Colorado River at the Imperial Dam in 1967 (fig. 21). Figure 21 shows the concentration of ${ }^{3} \mathrm{H}$ that would be expected, based on decay alone, in the same water today. The presence of measurable ${ }^{3} \mathrm{H}$ in ground water indicates that the water was recharged some time since 1952.

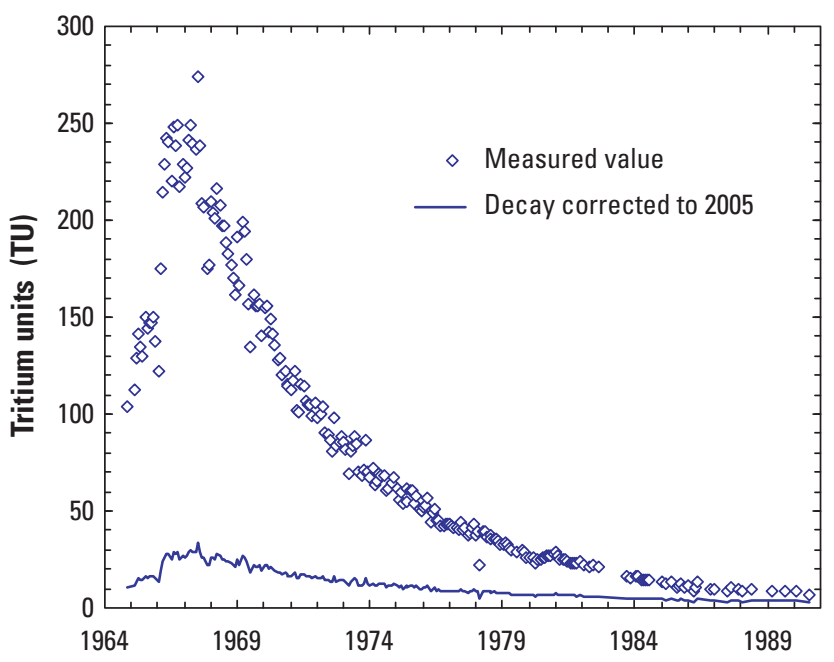

Figure 21. Tritium concentration in water sampled from the streamflow-gaging station along the Colorado River at Imperial Dam (USGS 09429490), 1964-1990.

${ }^{3} \mathrm{H}$ concentrations in water from wells sampled as part of this study ranged from less than $0.1 \mathrm{TU}$ to $18 \mathrm{TU}$. These values are summarized in figure 22 . In this study, water with a ${ }^{3} \mathrm{H}$ content less than or equal to $2 \mathrm{TU}$ is interpreted as "older" water recharged prior to 1952 . Water with ${ }^{3} \mathrm{H}$ content greater than 2 TU is interpreted as "recent" water recharged after 1952.

Wells that yielded recent water in this study are in valleys or near the mesa edge (fig. 22). For most of these wells, ${ }^{3} \mathrm{H}$ values are substantially higher than concentrations in present day Colorado River water or precipitation. The highest ${ }^{3} \mathrm{H}$ concentration (18 TU) was observed in water from the Fortuna Pond well. Considering only the right half of the peak in figure 21, this value corresponds to a period near 1970 , indicating a ground-water residence time of approximately 35 years. This estimate does not consider the potential for mixing with older, preexisting ground water or dispersion. A more refined estimate of ground-water residence time can be obtained through the coupled measurement of ${ }^{3} \mathrm{H}$ and ${ }^{3} \mathrm{He}$ (Ekwurzel and others, 1994).

Older water is present in water collected from wells 242-10, 242-22, USMC CADC, and Mesa del Sol \#35 (fig. 22). These wells are on Yuma Mesa, away from the flood-plain channel of the Colorado River. Low ${ }^{3} \mathrm{H}$ values indicate that ground-water recharge to these wells was not greatly influenced by local irrigation practices during the past 50 years.

To further characterize older ground water in the study area, water samples with very low or less than measurable ${ }^{3} \mathrm{H}$ concentrations were analyzed for ${ }^{14} \mathrm{C}$. ${ }^{14} \mathrm{C}$ is a radioisotope of carbon with a half-life of about 6,000 years. The amount of ${ }^{14} \mathrm{C}$ provides an estimate for ground-water residence time on the order of hundreds to thousands of years.

Carbon is introduced into the ground-water system during recharge, through plant respiration, decay of organic matter in soils, and dissolution of minerals and, as such, is subject to reactions that occur between dissolved constituents and the aquifer matrix (Fontes, 1985). Reactions adding carbon that does not contain ${ }^{14} \mathrm{C}$, or removing ${ }^{14} \mathrm{C}$ from the ground water, can result in misleading uncorrected ground-water ages.

${ }^{14} \mathrm{C}$ data collected as part of this study indicate a relatively large difference between water in wells 242-10 (59 pmc) and 242-22 (29 pmc). This corresponds to a residence time of 4,000 and 9,600 years (respectively) before present (table 6). These estimates are not corrected for potential exchange of carbon within the aquifer and, therefore, reflect the maximum (but not necessarily true) residence time of the water.

\section{Implications of Water-Chemistry Data on the Source and Movement of Ground Water in the Study Area}

Chemical, stable-isotope, and radioisotope data were combined to evaluate the source and movement of ground water in the Yuma area. Figure 23 shows an enlarged plot of the stable isotope values, grouped as recent or older water according to ${ }^{3} \mathrm{H}$ concentration. This integrated approach identified several distinct sources of ground water: (1) recent Colorado River water, (2) older Colorado River water, (3) irrigation water (from the Colorado River) and, (4) local recharge. The occurrence and movement of ground water from these different sources are discussed below.

An example of recently recharged Colorado River water in the study area is best represented by the water-quality data collected from well 242-2. Water from this well, which perforates the wedge zone, is characterized by an isotopically light ${ }^{18} \mathrm{O}$ value (about -14 per mil), a relatively low $\mathrm{D}$ residual (about 7 per mil), a moderate ${ }^{3} \mathrm{H}$ concentration $(8 \mathrm{TU}$ ), and a $\mathrm{Ca} / \mathrm{Na}-\mathrm{Cl} / \mathrm{SO}_{4}$ chemical composition. Water to well $242-2$ appears to be unaffected by irrigation from the mesa at this location. Although no other wells sampled had these same 
characteristics, this water likely occurs near and west of the river channel in Yuma Valley, and east at least as far as well 242-10.

Stable isotope data indicate the Colorado River also is the primary source of recharge to well 242-10. The absence of measurable ${ }^{3} \mathrm{H}(<0.1 \mathrm{TU})$ and relatively low ${ }^{14} \mathrm{C}(59 \mathrm{pmc})$ values indicate the presence of older water. The $\mathrm{Na}-\mathrm{Cl} / \mathrm{SO}_{4}$ chemical composition of well 242-10 distinguishes it from well 242-2. However, this older water is not entirely derived from the Colorado River. Differences in the stable isotope composition between 242-2 and 242-10 (fig. 23) can be explained by the movement of local recharge $(\sim 15$ percent on the basis of ${ }^{18} \mathrm{O}$ data) from the east.

Recharge of irrigation water from the Colorado River in the study area can be identified by a stable isotope composition that plots along or near the local evaporation line (generally -12 to -10 per mil ${ }^{18} \mathrm{O}$; fig. 23) and has a relatively large D residual (for example, SG-10r, YM-10, and Fortuna Pond). These waters also have a relatively high ${ }^{3} \mathrm{H}$ concentration (10-18 TU). Isotopic data show the movement of this source of recharge from Yuma Mesa to Yuma and South Gila Valley areas. Other wells in the area would be expected to yield water having similar isotopic signatures/characteristics, depending on their proximity to nearby irrigation operations.

Local recharge in the study area is isotopically heavy, relative to sources originating from the Colorado River. Local water (about -8.5 per mil ${ }^{18} \mathrm{O}$ ) was present in the Mesa del Sol \#35 and USMC CADC wells; this also is older water (fig. 23). Data collected at well 242-22 (about -8 per mil ${ }^{18} \mathrm{O}$ ) provide an example of local recharge of significant age $\left(29 \mathrm{pmc}{ }^{14} \mathrm{C}\right)$ that is further distinguished by a $\mathrm{Na}-\mathrm{Cl}$ chemical composition and low dissolved-solids concentration $(801 \mathrm{mg} / \mathrm{L})$.

The results of new isotopic data collected as part of this study suggest that water from the Colorado River is the dominant source of recharge to the area, and a substantial portion of Yuma Mesa (eastern) recharge is derived from local infiltration of precipitation. The isotopic data, though limited, enhance the understanding of the flow system and provide insight into the source and movement of recharge in other areas. With the exception of the wells in the 242 Wellfield near the U.S.-Mexican border, isotopic data generally indicate that recent water from the Colorado River is being pumped from wells operated by Reclamation.

\section{Discussion of Results of Wellbore Velocity Profile and Depth-Dependent Sampling}

Results of the tracer-pulse (dye-injection) test and depth-dependent sampling at well YM-10 are summarized in figure 24. The purpose of this field test was (1) to identify how potentially distinct waters drawn from a well are extracted from different parts of the aquifer system, and (2) to characterize those differences. Perforations for well YM-10 primarily are open to the coarse-gravel unit. During the field test, peak time-of-arrival between 150-200 ft ranged from 202 seconds, respectively. Arrival times were reproducible- typically to within 1 or 2 seconds. Total discharge was recorded every 15 minutes; the median discharge during the field test was approximately $3,300 \mathrm{gal} / \mathrm{min}$.

Results of the tracer-pulse (dye-injection) test indicate that about two-thirds of the water in well YM-10 is drawn from the lower half of the well perforations, and about one-third of the water is drawn from the upper half of the well perforations. Only one-fifth of the total flow is drawn below $200 \mathrm{ft}$. Measurements indicate that a large increase in flow, about 45 percent, occurs between 190 and $200 \mathrm{ft}$. Additional increases in flow occur at 170 and $160 \mathrm{ft}$, about 10 and 20 percent, respectively. The contribution to overall flow in the well above $160 \mathrm{ft}$ is relatively small (less than 5 percent). Some improvement in flow-profile resolution could be gained by making additional measurements at 5-foot intervals under a substantially lower pumping rate. Additional data-collection efforts utilizing this technique should focus on a deeper well with a longer perforated interval that, preferably, is open to more than one hydrogeologic unit.

Depth-dependent data indicate slight variations in water quality with respect to depth. For example, specific conductance decreases from 1,950 to $1,800 \mu \mathrm{S} / \mathrm{cm}$ at 154 and $194 \mathrm{ft}$, respectively. $\mathrm{pH}$ and nitrate concentrations increased with depth; D values decreased; ${ }^{3} \mathrm{H}$ (not shown) remained essentially unchanged. The concentration of other chemical constituents at the sampled depths did not change or vary appreciably. In general, these differences, although small, occurred within a single HGU (the coarse-gravel unit). In addition, concentrations at the wellhead ('bulk' sample) often differed from the depth sample at $154 \mathrm{ft}$, suggesting that a chemically distinct zone between $154 \mathrm{ft}$ and the top of the screen contributes to the overall chemical composition of the well water.

\section{Review of Water Budget Components}

A water budget consists of an accounting of water resources for a period of time. This study reviews waterbudget components for the Yuma area related to the groundwater flow system from 1970 to 1999 . Specifically reviewed in this study are the components included in the groundwater flow model developed by William Greer (Bureau of Reclamation, hydrologist, written commun., 2005) in Yuma, Arizona. This review was done for the purpose of documenting the methods and results and to identify components of the water budget that could be refined. While the ground-water model calculates water-budget components as part of the ground-water flow solution, this report describes components that were calculated external to the model.

A history of water-resources development in the Yuma area and a detailed summary of water deliveries for subregions within the Yuma area for the period 1960-63 are provided by Olmsted and others (1973). Water-budget components described by Olmsted and others (1973) probably are similar to conditions for the period 1970-99 except for ground-water withdrawals by drainage wells along the western edge of Yuma Mesa and withdrawals by Mexico and the United States from wells along the SIB. 


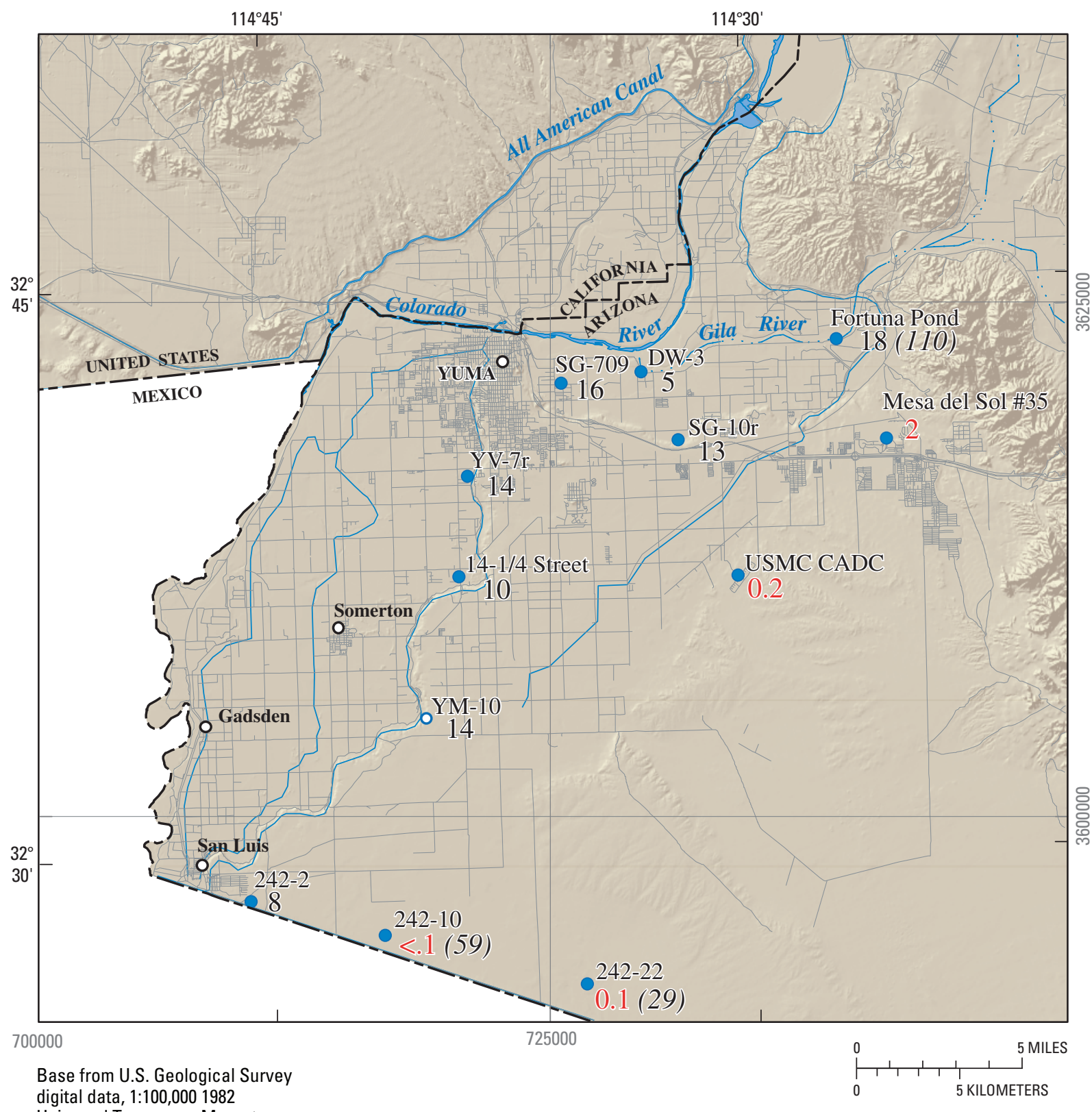

digital data, 1:100,000 1982

Universal Transverse Mercator projection, Zone 11

EXPLANATION

Well and well identifier

(59) Carbon-14 activity, in percent modern carbon.

$\begin{array}{ll}0^{242-10} & \text { Routine sample } \\ \text { oM-10 } & \text { Routine and downhole sample }\end{array}$

8 Tritium concentration, in tritium units. Values in red denote "older water". $<$ is less than.

Figure 22. Tritium concentrations and carbon-14 activity in water samples collected from wells in the Yuma area. 


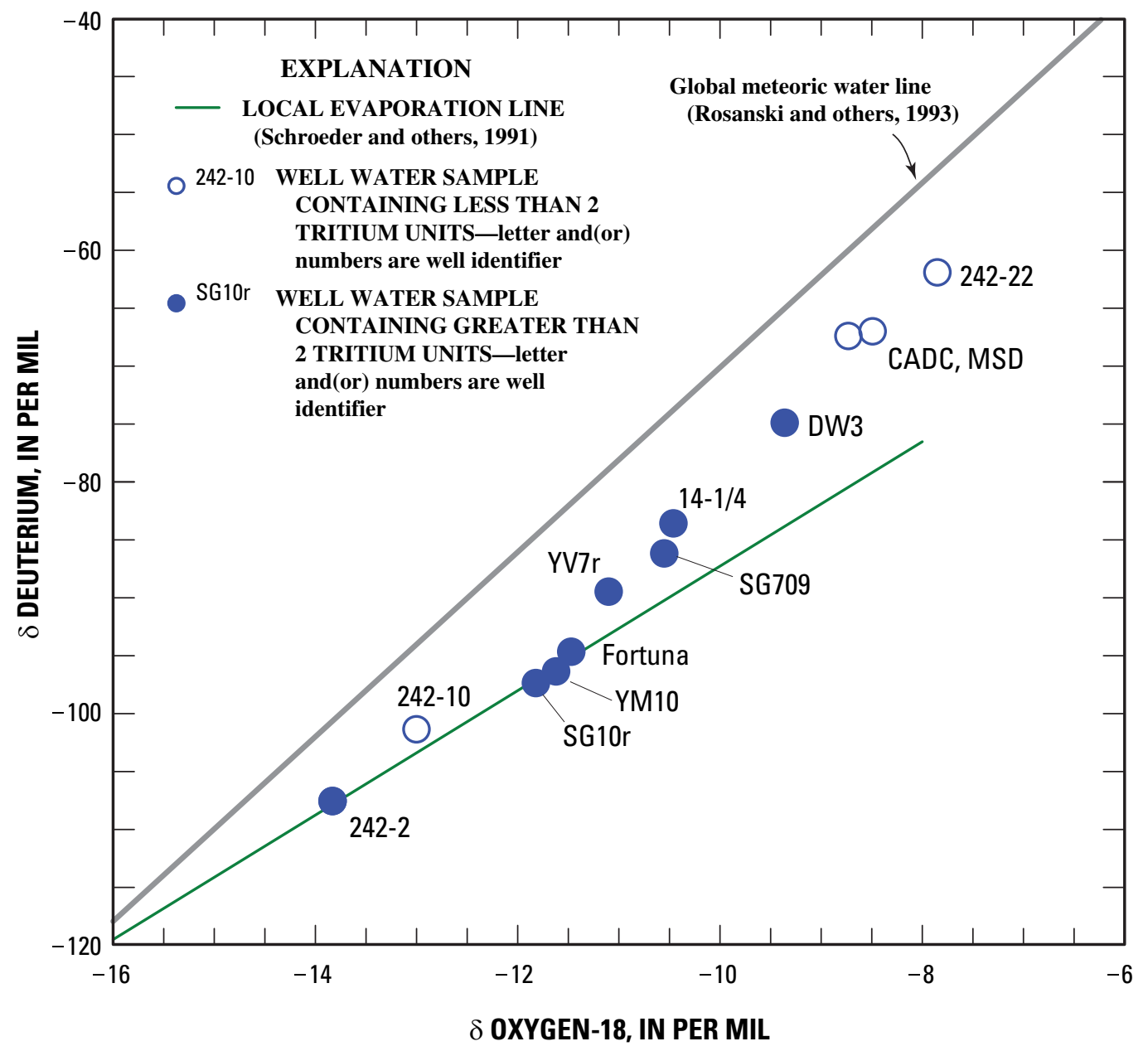

Figure 23. $\delta$ deuterium as a function of $\delta$ oxygen-18, grouped by tritium concentration in ground water sampled in the Yuma area, April-September 2005. 


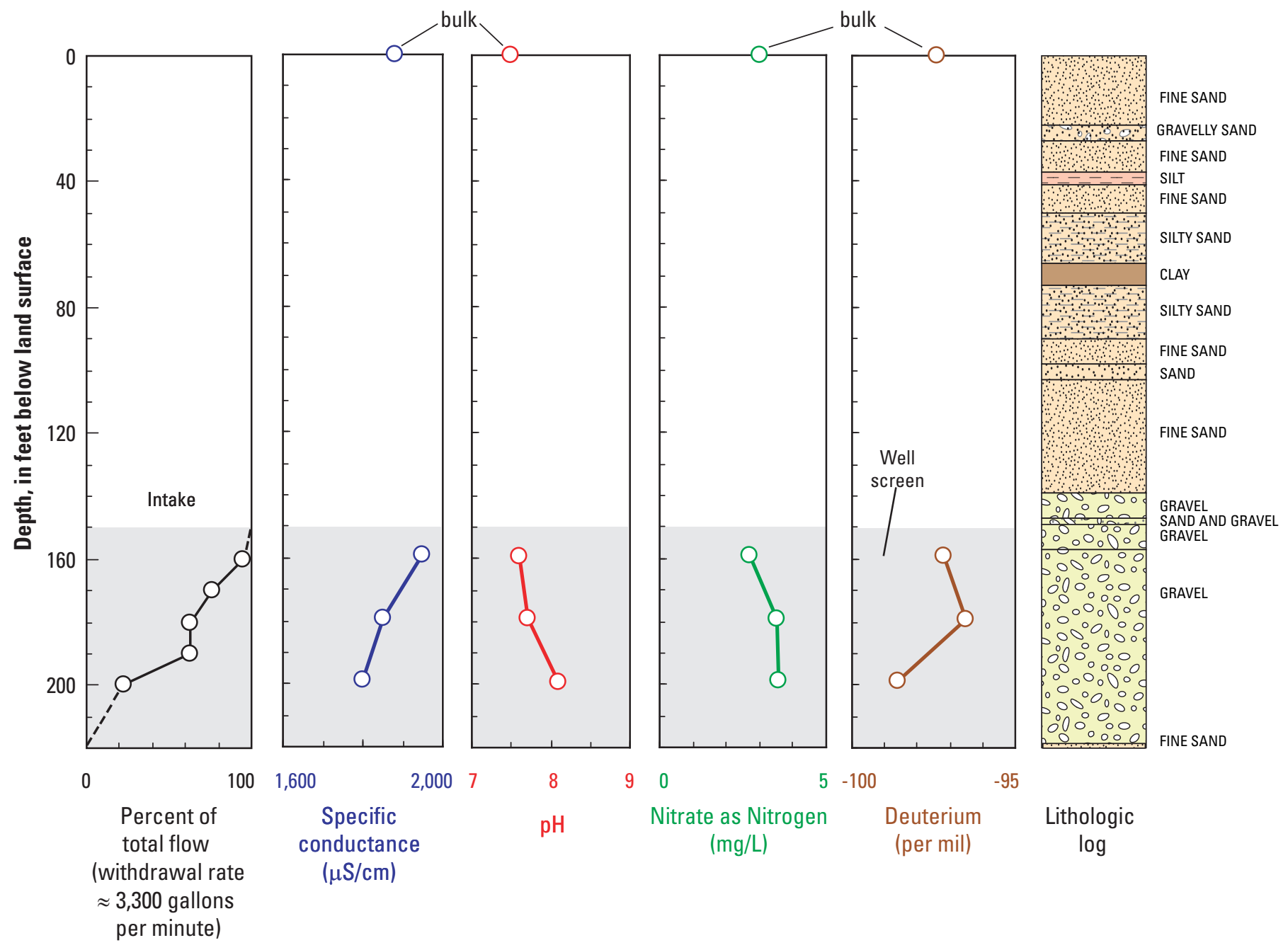

Figure 24. Velocity profile, selected water-quality data, and lithologies at depth intervals at well YM-10, September 2005.

The water budget for the model and for this evaluation is for the period 1970-99. The year 1970 serves as the steadystate period of the ground-water model. Each following year represents transient ground-water flow conditions.

\section{Ground-Water Budget Data and Approach}

The water budget comprises inflows and outflows to the ground-water system. Inflows consist mainly of ground-water recharge owing to excess water applied for irrigation and canal leakage. No significant recharge occurs from direct infiltration from precipitation because the minimal precipitation in the Yuma area evaporates before deep percolation to the water table can occur at most places (Olmsted and others, 1973). As noted in the "Ground Water" section, there is likely a small amount of episodic recharge in arroyos from precipitation in adjacent mountains. Isotopic data presented in the section on "Water-chemistry data at selected sites in Yuma Valley, South Gila Valley, and Yuma Mesa," indicate that local recharge of precipitation is a component of recharge to ground water in some parts of Yuma Mesa. Outflows consist mainly of discharge from the aquifer system to the Colorado River, underflow across the limotrophe section and the SIB, evapotranspiration (ET) by phreatophytes along riparian reaches, withdrawal of water from wells, and discharge to the surface drains within Yuma and South Gila Valleys. Outflow components calculated external to the model are deliveries by canals for crop requirements, rates of ET by phreatophytes, ground-water withdrawals from wells, and ground-water discharge to the Colorado River between Laguna Dam and the NIB.

\section{Evapotranspiration}

For this study, ET includes the consumptive use of water by crops and phreatophytes, evaporation from bare soil, and evaporation from free-water surfaces. Although crop ET is not considered outflow from the aquifer because water uptake is primarily irrigation water, it is subtracted from the applied water in order to estimate the amount of deep percolation of 
excess irrigation water. Consumptive use has been defined as the unit amount of water required for a given area for transpiration, construction of plant tissue, and evaporation from adjacent soil (Erie and others, 1965). ET occurs mainly at irrigated areas and riparian reaches having extensive areas of phreatophytes.

\section{Evapotranspiration by Irrigated Crops}

Crop ET was calculated by using the methods of Reclamation's the Lower Colorado River Accounting System (LCRAS) program of the Lower Colorado Region. ET was calculated for irrigated zones within irrigation districts and other cropped areas as shown in figure 25 . These zones were delineated by using the Agricultural Development Maps in the Yuma Area Ground Water Status Reports, 1970-94. Zones were delineated for each year from 1970 to 1994 on the basis of the appropriate Agricultural Development Map for each year (William Greer, hydrologist, Bureau of Reclamation, written commun., 2005). Changes from year to year, however, were minor. No zones were changed after 1994. Irrigated zones were digitized by using a GIS program and incorporated into the domain of the ground-water flow model.

Because ET is difficult to measure directly, it commonly is calculated by using surrogates for ET applied to large areas of interest. A frequently used reference ET rate, ETo, is a fundamental rate of water use that can be related to the water use of all types of vegetation. A particular crop's ET is calculated by

$$
E T=E T o \times K c-P e,
$$

where

$$
\begin{gathered}
K c=\text { is a factor related to individual crop types, and } \\
P e=\text { is the effective precipitation determined by } \\
\text { multiplying the measured precipitation by an } \\
\text { effective precipitation coefficient. }
\end{gathered}
$$

ET was calculated for 16 crop types that were reported in crop census reports and averaged for each month from 1970 to 1999 (http://www.nass.usda.gov:8080/QuickStats/Create_ Federal_All.jsp, accessed July 24, 2000). Daily values of ETo and $P e$ were obtained from The Arizona Meteorological Network (http://ag.arizona.edu/azmet/, accessed July 14, 2000) from 1989-99 for the Yuma Valley, Yuma Mesa, and Yuma North Gila stations. $K c$ values were provided by Jensen (1998). First, daily ET values for each crop type at each station were calculated by using daily $K c$ and the daily $E T_{o}$ and $P_{e}$ values. Second, monthly ET for each station during the 11-year period was averaged to obtain monthly ET crop values. Second, monthly ET values for each crop type at each station were calculated by averaging the daily ET values for each month at each station. Third, to obtain average monthly ET values for each crop in the Yuma area, the average monthly ET values for each crop at each of the 3 stations was calculated. Finally, the average monthly ET values for each crop were reduced by 8 percent, so that the ET values were similar to other estimates done by Reclamation along other reaches of the Colorado River. Monthly averages of $E T_{o}$ and $K c$ for each crop type are presented in table 7 . The volume of crop ET for each irrigations zone per stress period in the ground-water flow model is included in table 8 .

\section{Evapotranspiration by Phreatophytes}

Phreatophytes are found along most reaches of the Colorado River, along parts of the Gila River, along reaches of the All-American Canal, and in the area between the Colorado River and the All-American Canal near the Gila River confluence known as "The Island". To use the approach taken by Reclamation to calculate ET, a ground-water flow model is necessary to calculate temporal changes in ET dependent on transient ground-water conditions. ET by phreatophytes is included in the ground-water budget because (1) it is assumed that the plant roots are dependent on the presence of generally shallow ground-water levels, and (2) the use of water by phreatophytes can affect the flow of ground water on a regional basis. The spatial extent of phreatophytes, maximum rates of ET, and depth of the plant roots are required data for input to the model. The discussion here focuses on the calculations done by Reclamation concerning these basic data and new sources of data that potentially can be used to improve the model.

The method used to calculate the ET rate by phreatophytes was identical to the approach taken to calculate the ET rate of crops in irrigated areas by using equation 1 . The spatial distributions of phreatophytes were taken from extent maps contained in GIS databases from the LCRAS group at the Reclamation office in Boulder City, Nevada. The locations of the phreatophytes were matched spatially with the grid of the numerical model. The maps contain representative areas of different types of phreatophytes. Salt cedar, mesquite, arrow-weed, and cottonwood were identified as the most dominant species. These phreatophytes were divided into 14 groups that have intensities of high and low and mixed combinations shown in table 9. The 14 groups are described in more detail in Reclamation's annual LCRAS reports (William Greer, hydrologist, Bureau of Reclamation, 2004). The 14 groups were further simplified into three categories for the model input. The three categories are (1) marsh, (2) desert vegetation and barren areas, and (3) an average of the 11 other groups. The monthly averages of $K c$ for the 14 groups are shown in table 9. The monthly rates were summed to obtain annual average rates, which were converted to daily rates. Calculated values of ET for each phreatophyte group are presented in table 10. 


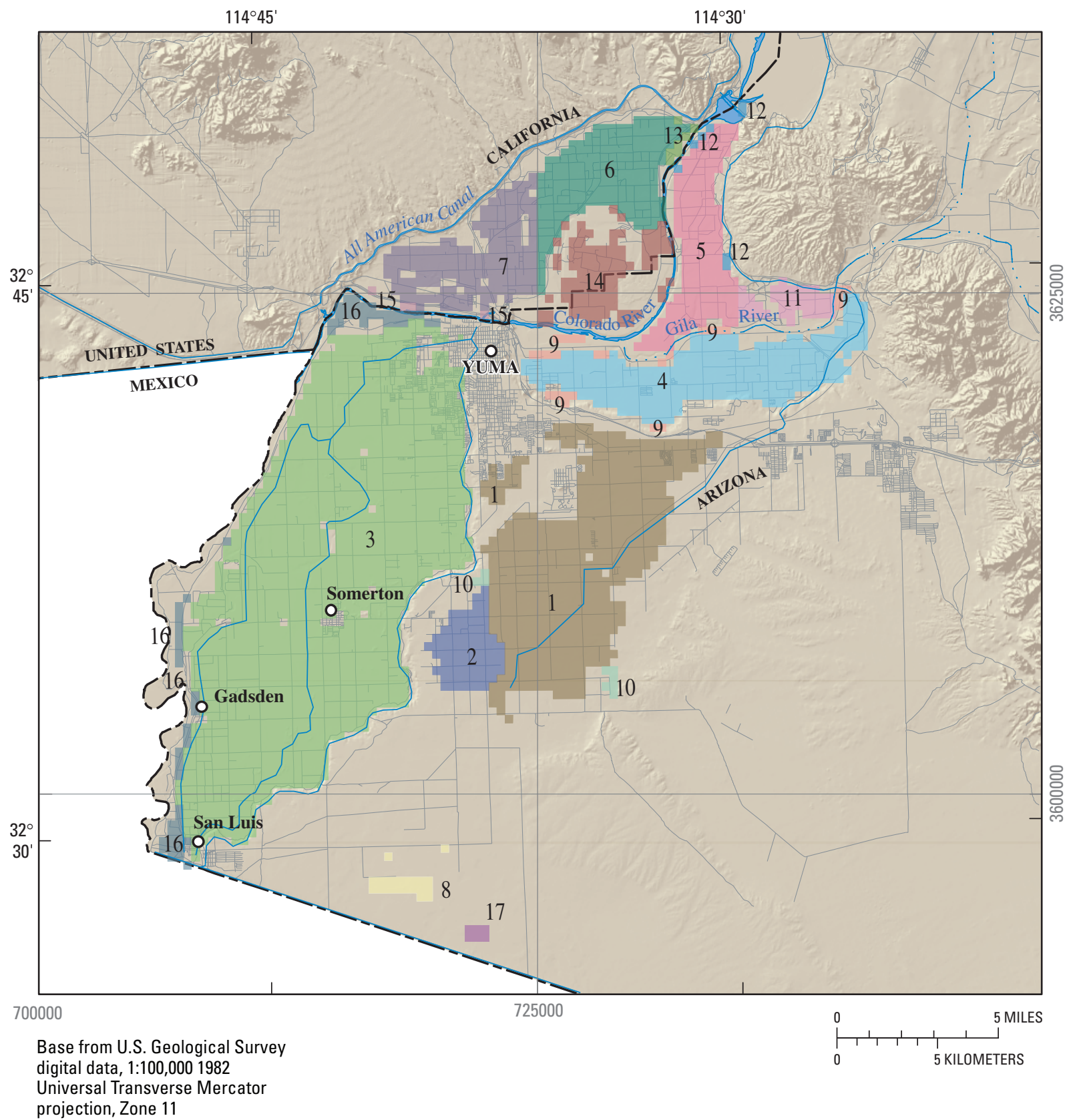

Figure 25. Zones representing irrigated areas having calculations of recharge and evapotranspiration, Yuma area. 


\begin{tabular}{|clr|}
\hline \multicolumn{1}{c}{ EXPLANATION } & \\
\hline Zone & \multicolumn{1}{c|}{ Irrigation Districts in 1970 } & Area, in acres \\
\hline 1 & Yuma Mesa Irrigation and Drainage District & 21,000 \\
2 & Unit B Irrigation and Drainage District & 3,200 \\
3 & Yuma County Water Users' Association & 54,640 \\
4 & Yuma Irrigation District (S. Gila Valley) & 11,040 \\
5 & North Gila Irrigation District & 6,320 \\
6 & Bard Water District & 7,360 \\
7 & Indian Unit & 6,600 \\
8 & Hillander "C" & 800 \\
9 & Outside Yuma Irrigation District (South Gila Valley) & 1,080 \\
10 & Outside of Yuma Mesa Irrigation and Drainage District & 360 \\
11 & Gila Monster Ranch & 1,560 \\
12 & Outside North Gila Irrigation District & 320 \\
13 & Outside Bard Water District & 280 \\
14 & Island & 4,240 \\
15 & Outside Indian Unit & 160 \\
16 & Outside Yuma County Water Users' Association & 2,520 \\
17 & Morton Farms (no crops were grown in this area for period 1970-1999) & 240 \\
& Mexico & 427,839 \\
\hline
\end{tabular}

Figure 25. Continued.

Additional regional ET data are available that use new relations between remote sensing and meteorological data. Nichols and others (2004) compared the accuracy of direct measurements of ET by using eddy covariance at flux towers along the Middle Rio Grande to ET calculations by using crop coefficients. Nichols and others (2004) determined that ET estimates made by using crop coefficients were not applicable to riparian vegetation because $K c$ does not change with respect to changes in water availability and other stresses. ET has been calculated for large river reaches in the western United States by combining Enhanced Vegetative Index values from the Moderate Resolution Imaging Spectrometer (MODIS) satellite with in-place measurements by using flux towers (Nagler and others, 2005). These data indicate that ET rates are about half an order of magnitude lower than estimates using crop coefficients (Nagler and others, 2005). For example, calculated ET rates of salt cedar ranged from $11.81 \mathrm{in} / \mathrm{yr}$ to $51.18 \mathrm{in} / \mathrm{yr}$, while ET rates for salt cedar using crop coefficient methods were $51.30 \mathrm{in} / \mathrm{yr}$ for low stands and $62.27 \mathrm{in} / \mathrm{yr}$ for high stands. In addition, the MODIS data can be processed for 16-day intervals, which would improve the temporal variability of ET for additional simulation periods by the ground-water flow model. ET estimates from remote sensing and meteorological data, and those from crop coefficient methods, can be used to provide an estimate of uncertainly of the ground-water flow model related to the different estimates. Additional studies would be needed to determine if these ET estimates are more accurate than estimates made by using crop coefficient methods.

\section{Recharge at Irrigated Areas}

A significant source of ground-water recharge occurs as deep percolation from excess water applied to crops. Crops in the Yuma area are entirely dependent on irrigation for their water supply. The amount of deep percolation depends upon the efficiency of irrigation practices, which has generally increased with time. The earliest irrigation began about 1897 (Olmsted and others, 1973) along the flood plains of the Colorado and Gila Rivers and depended on water from the Colorado River. The amount of irrigated area had grown to about 100,000 acres by 1999. Irrigation on Yuma Mesa developed after World War II for the cultivation of citrus orchards. Diverted surface water was used for irrigation in most areas with the exception of parts of South Gila Valley and the southern part of Yuma Mesa outside of water districts (Olmsted and others, 1973). 
Table 7. Average monthly evapotranspiration parameters for irrigated crops by using climate data for 1989-1999, Yuma area.

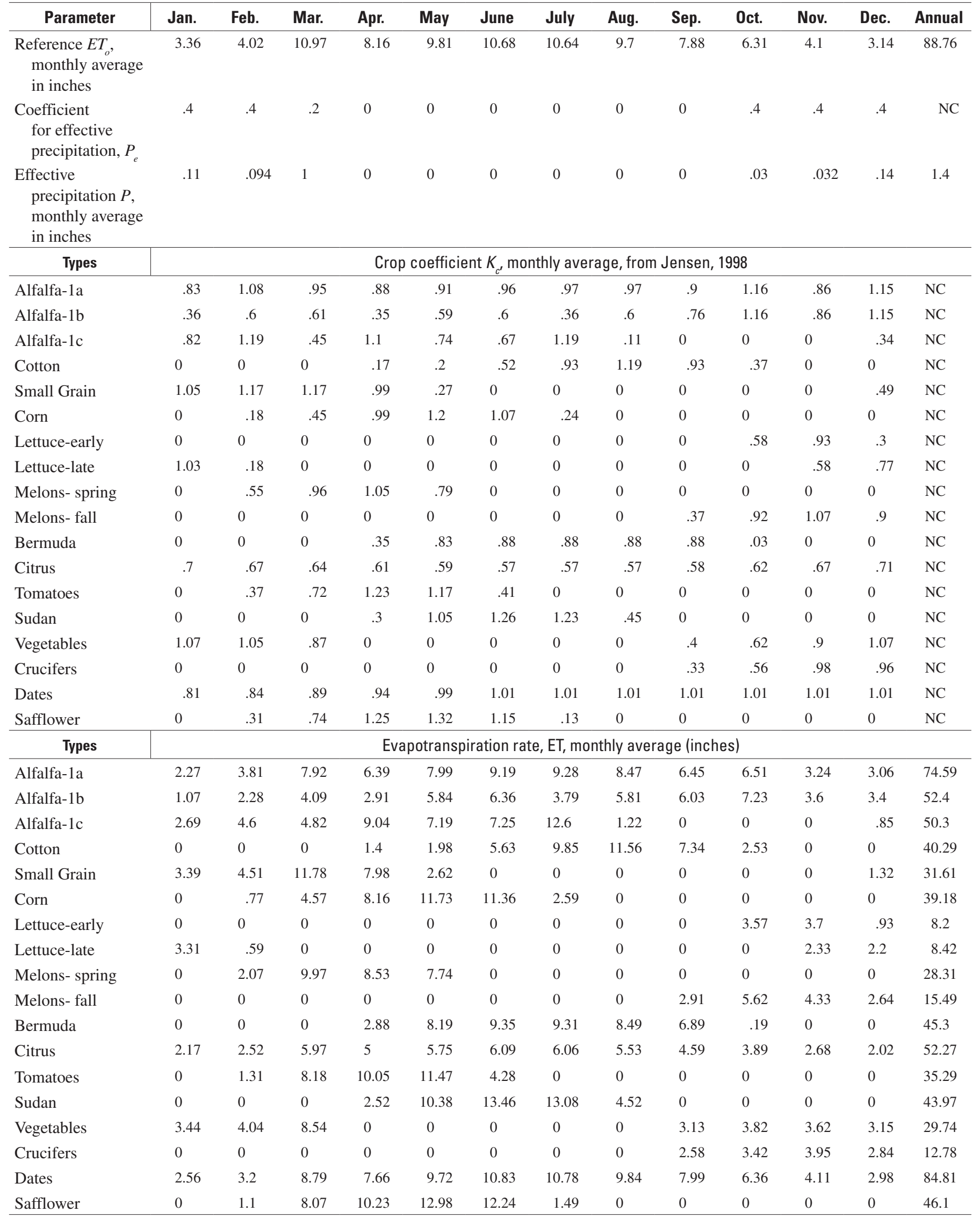


Table 8. Evapotranspiration rate per zone for irrigated crops, 1970-1999, Yuma area.

[No data for zone 17]

Evapotranspiration rate per zone, in acre-feet

\begin{tabular}{|c|c|c|c|c|c|c|c|c|c|c|c|c|}
\hline Start date & End date & 1,10 & 7,15 & 2 & 3,16 & 4,9 & 5,12 & 6,13 & 8 & 14 & 11 & 18 \\
\hline $04 / 1970$ & 03/1971 & 71,666 & 18,508 & 12,665 & 188,555 & 45,520 & 23,338 & 22632 & 3,310 & 13,038 & 5,483 & $1,551,274$ \\
\hline 04/1971 & 09/1971 & 44,113 & 9,657 & 7,749 & 119,375 & 30,174 & 11,169 & 14,183 & 1,652 & 7,871 & 2,759 & 856,054 \\
\hline 10/1971 & 03/1972 & 28,098 & 6,514 & 4,915 & 72,214 & 14,616 & 7,844 & 7,725 & 1,052 & 4,287 & 1,937 & 719,708 \\
\hline 04/1972 & 09/1972 & 43,647 & 10,401 & 7,749 & 122,188 & 30,399 & 11,434 & 10,950 & 1,635 & 6,077 & 2,962 & 858,202 \\
\hline 10/1972 & 03/1973 & 28,132 & 5,430 & 4,915 & 82,520 & 17,603 & 8,094 & 6,467 & 1,054 & 3,589 & 2,097 & 638,969 \\
\hline $04 / 1973$ & $09 / 1973$ & 43,880 & 15,970 & 7,749 & 112,877 & 28,062 & 10,949 & 16,234 & 2,219 & 9,180 & 2,836 & 794,788 \\
\hline $10 / 1973$ & 03/1974 & 27,077 & 6,261 & 4,915 & 73,322 & 14,651 & 8,739 & 6,977 & 1,369 & 3,945 & 2,264 & 717,245 \\
\hline 04/1974 & 09/1974 & 41,354 & 11,044 & 7,749 & 115,317 & 24,620 & 24,275 & 15,500 & 3,640 & 8,764 & 6,288 & 913,896 \\
\hline $10 / 1974$ & $03 / 1975$ & 28,190 & 7,172 & 5,187 & 78,597 & 17,905 & 10,095 & 8,900 & 2,481 & 5,032 & 2,615 & 659,310 \\
\hline $04 / 1975$ & $09 / 1975$ & 43,855 & 9,165 & 7,896 & 96,675 & 22,488 & 9,149 & 11,932 & 3,860 & 6,747 & 2,370 & 886,951 \\
\hline $10 / 1975$ & 03/1976 & 29,458 & 5,077 & 5,211 & 82,115 & 20,212 & 8,794 & 9,462 & 2,593 & 5,350 & 2,278 & 721,594 \\
\hline 04/1976 & 09/1976 & 44,427 & 11,669 & 7,783 & 121,048 & 24,441 & 12,876 & 15,851 & 4,742 & 8,963 & 3,335 & 809,395 \\
\hline $10 / 1976$ & 03/1977 & 27,183 & 3,487 & 4,148 & 55,239 & 14,185 & 8,780 & 6,656 & 2,902 & 3,764 & 2,274 & 721,698 \\
\hline 04/1977 & 09/1977 & 41,677 & 15,521 & 5,828 & 125,428 & 27,071 & 14,241 & 18,392 & 4,471 & 10,400 & 3,689 & 853,070 \\
\hline 10/1977 & 03/1978 & 27,139 & 4,279 & 4,355 & 60,537 & 16,638 & 10,813 & 6,443 & 2,911 & 3,643 & 2,801 & 628,773 \\
\hline $04 / 1978$ & 09/1978 & 45,277 & 14,107 & 8,426 & 115,812 & 23,213 & 11,334 & 19,506 & 4,901 & 11,030 & 2,936 & 833,586 \\
\hline $10 / 1978$ & 03/1979 & 29,311 & 2,482 & 5,211 & 67,333 & 13,752 & 8,024 & 5,301 & 3,173 & 2,997 & 2,079 & 614,416 \\
\hline 04/1979 & 09/1979 & 48,851 & 19,665 & 8,302 & 116,087 & 22,519 & 11,859 & 18,639 & 5,087 & 10,539 & 3,072 & $1,149,437$ \\
\hline $10 / 1979$ & 03/1980 & 32,064 & 3,895 & 5,079 & 55,633 & 16,505 & 9,510 & 7,474 & 3,339 & 4,226 & 2,464 & 898,671 \\
\hline 04/1980 & 09/1980 & 51,699 & 18,559 & 7,550 & 124, & 24,8 & 12,910 & 17,625 & 4,854 & 9,966 & 3,344 & $1,348,834$ \\
\hline $10 / 1980$ & 03/1981 & 31,081 & 5,022 & 4,683 & 58,683 & 14,496 & 10,016 & 7,823 & 2,918 & 4,424 & 2,594 & 948,994 \\
\hline 04/1981 & 09/1981 & 45,546 & 13,043 & 7,241 & 123,070 & 27,249 & 12,575 & 17,358 & 4,166 & 9,815 & 3,257 & $1,039,722$ \\
\hline $10 / 1981$ & 03/1982 & 32,932 & 5,774 & 4,357 & 63,439 & 15,313 & 10,301 & 9,338 & 3,012 & 5,280 & 2,668 & 706,887 \\
\hline 04/1982 & $09 / 1982$ & 58,879 & 9,934 & 7,254 & 113,492 & 21,493 & 11,940 & 17,380 & 5,336 & 9,827 & 3,093 & 803,405 \\
\hline $10 / 1982$ & $03 / 1983$ & 37,808 & 3,203 & 4,532 & 58,703 & 13,737 & 9,300 & 8,823 & 3,427 & 4,989 & 2,409 & 755,977 \\
\hline $04 / 1983$ & $09 / 1983$ & 60,166 & 4,421 & 7,528 & 91,903 & 20,468 & 10,125 & 15,382 & 5,044 & 8,698 & 2,623 & $1,315,251$ \\
\hline $10 / 1983$ & 03/1984 & 39,047 & 4,755 & 4,551 & 74,092 & 16,296 & 11,521 & 9,663 & 3,273 & 5,464 & 2,984 & $1,131,856$ \\
\hline 04/1984 & 09/1984 & 60,831 & 6,695 & 7,330 & 105,122 & 15,580 & 18,338 & 15,871 & 3,791 & 10,138 & 5,479 & $1,294,174$ \\
\hline $10 / 1984$ & $09 / 1985$ & 38,672 & 5,902 & 4,658 & 80,798 & 17,182 & 13,935 & 10,474 & 2,410 & 6,690 & 4,164 & 891,606 \\
\hline $04 / 1985$ & 09/1985 & 62,403 & 6,859 & 7,561 & 93,835 & 15,211 & 8,654 & 13,481 & 3,889 & 8,611 & 2,586 & $1,306,680$ \\
\hline $10 / 1985$ & 03/1986 & 38,392 & 6,162 & 4,849 & 79,229 & 18,454 & 10,633 & 9,298 & 2,392 & 5,939 & 3,177 & $1,070,774$ \\
\hline 04/1986 & 09/1986 & 59,098 & 5,859 & 7,632 & 94,763 & 15,847 & 8,088 & 12,643 & 3,683 & 8,075 & 2,416 & $1,258,492$ \\
\hline $10 / 1986$ & 03/1987 & 38,048 & 5,995 & 4,962 & 68,414 & 17,833 & 7,686 & 11,386 & 2,371 & 7,273 & 2,296 & 906,064 \\
\hline 04/1987 & 09/1987 & 60,985 & 9,904 & 7,831 & 113,222 & 14,454 & 13,312 & 15,803 & 3,800 & 10,094 & 3,977 & $1,040,089$ \\
\hline $10 / 1987$ & 03/1988 & 37,955 & 6,587 & 5,356 & 71,173 & 16,958 & 8,894 & 12,687 & 2,365 & 8,103 & 2,657 & 906,454 \\
\hline 04/1988 & 09/1988 & 58,395 & 16,495 & 7,424 & 119,009 & 16,661 & 6,818 & 20,853 & 3,639 & 13,320 & 2,037 & 974,009 \\
\hline $10 / 1988$ & 03/1989 & 37,309 & 8,172 & 4,989 & 76,390 & 19,938 & 8,885 & 11,556 & 2,325 & 3,180 & 2,655 & 728,301 \\
\hline $04 / 1989$ & 09/1989 & 59,455 & 14,039 & 7,447 & 102,298 & 19,821 & 11,139 & 17,604 & 4,998 & 11,244 & 3,328 & 890,364 \\
\hline $10 / 1989$ & 03/1990 & 37,562 & 8,666 & 4,745 & 78,734 & 19,307 & 7,756 & 13,635 & 3,158 & 8,709 & 2,317 & 694,689 \\
\hline 04/1990 & 09/1990 & 59,625 & 11,536 & 7,409 & 102,351 & 16,921 & 4,788 & 27,692 & 5,013 & 17,688 & 1,431 & 844,334 \\
\hline
\end{tabular}


Table 8. Evapotranspiration rate per zone from irrigated crops, 1970-1999, Yuma area-Continued.

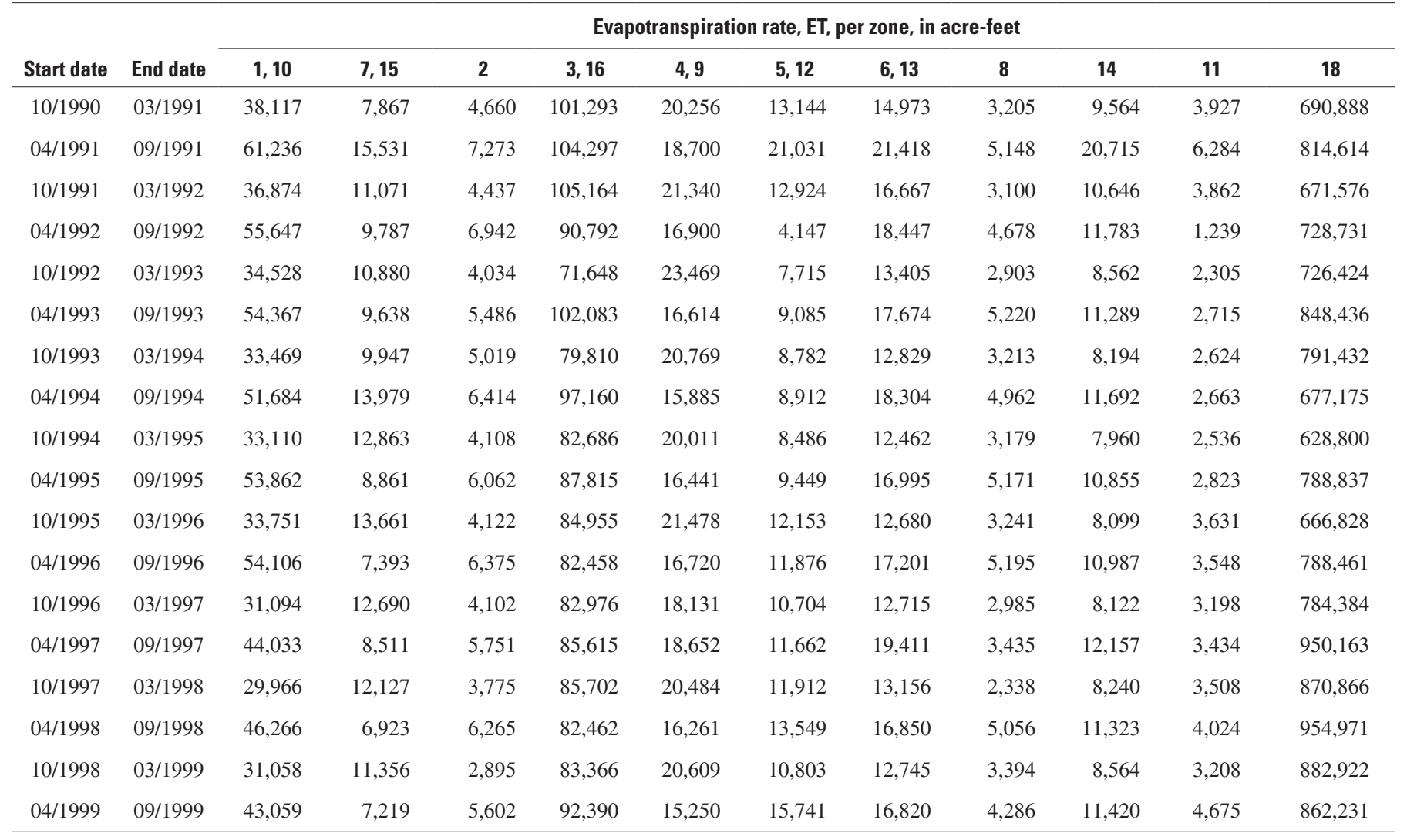

Table 9. Monthly values of crop coefficients for vegetation groups, Yuma area.

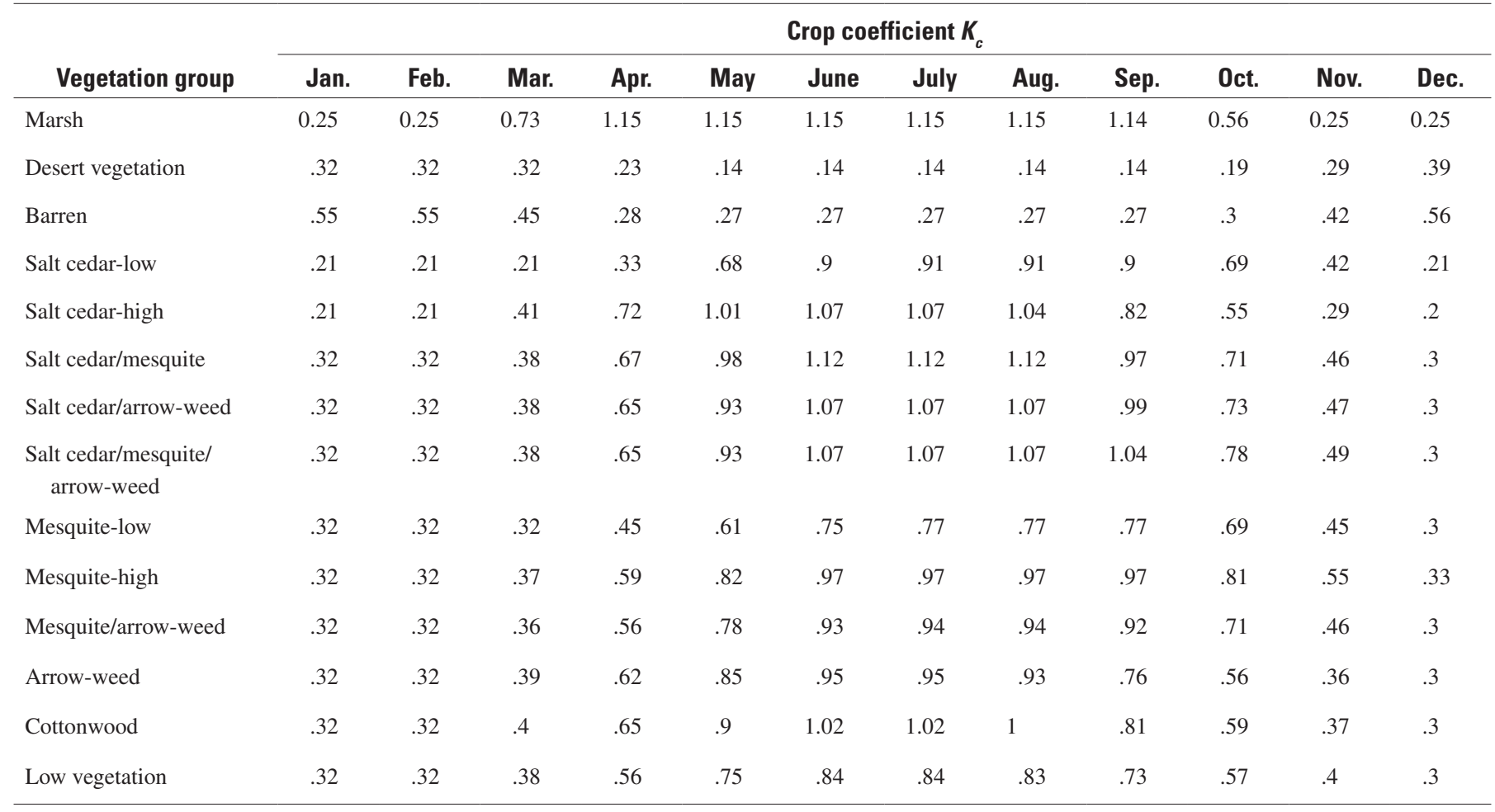


Table 10. Monthly averages of evapotranspiration for vegetation groups, Yuma area.

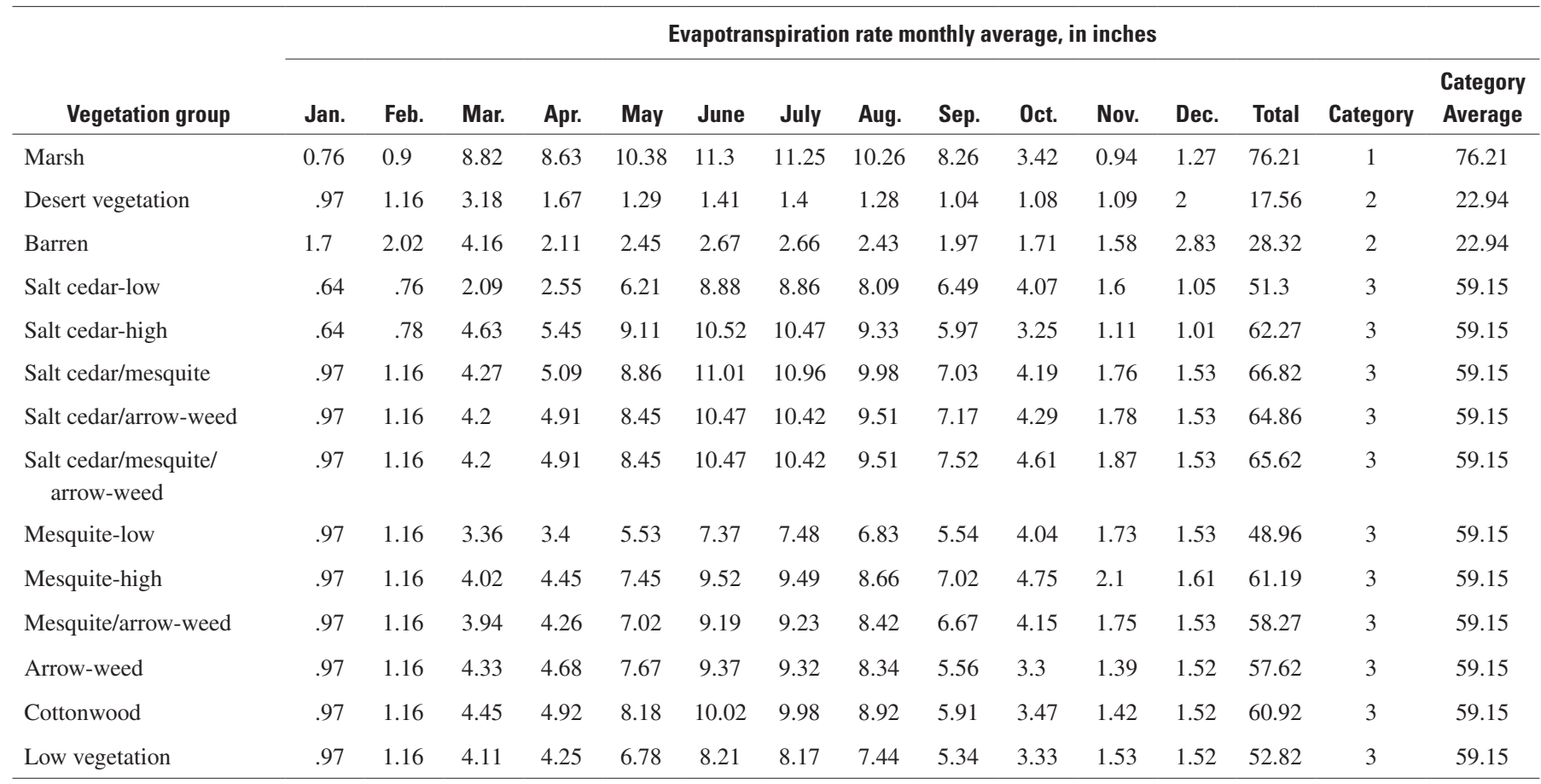

Calculation of recharge rates as applied stresses to Reclamation's ground-water flow model is summarized as follows. Recharge was calculated for irrigation zones that generally correspond to boundaries of the irrigation districts listed in figure 25. These zones, which varied in size somewhat from year to year, were delineated on the bases of the Agricultural Development Maps from the Yuma Area Ground Water Status Reports. Irrigated areas outside the boundaries of service of an irrigation district were assumed to be receiving water from the nearest district and to have the same crop types. Wells not identified as providing water for drainage were assumed to provide additional water for irrigation. Withdrawals from these wells were applied to the recharge zone in which the well was located or the nearest zone if the well was located outside of a recharge zone. A single recharge rate for each stress period was calculated for each irrigation district and the cropped areas just outside the district boundary.

The volume of recharge $R v$, in acre- $\mathrm{ft}$, was calculated for each irrigated area as

$$
R v=W-E T,
$$

where

$$
\begin{gathered}
W=\text { the amount of irrigation water delivered, and } \\
E T=\text { the evapotranspiration calculated by using } \\
\text { equation } 2 .
\end{gathered}
$$

$R v$ for each zone per model stress period is provided in table 11 . The recharge rate $R$, in feet per day, was calculated for each zone by dividing $R v$ by the area of each zone, in acres, and dividing by the number of days in the year.

The amount of water delivered, $W$, for each recharge zone was compiled from Annual Crop Census Reports, obtained from Central Files and the Water Operations Group, YAO of Reclamation (William Greer, hydrologist, Bureau of Reclamation, written commun., 2005). Water delivery data were available for the following irrigation districts: Yuma Mesa Irrigation and Drainage District; Unit B Irrigation and Drainage District; North Gila Irrigation District; Bard Water District; Yuma Irrigation District; Yuma County Water Users' Association; and Indian Unit. Data were not available for water delivered to the Unit B Irrigation and Drainage District for 1978; therefore, an estimate of the delivery was made by using 1977 and 1979 delivery data and data from the Decree Accounting records for 1977-79. While most irrigation water is diverted surface water, some water in several zones was obtained from pumps drawing directly from the Colorado River or from ponds. Annual figures for these withdrawals were obtained from Ground Water Status Reports (Bureau of Reclamation, 2004) for years 1970-94 and from Decree Accounting records (William Greer, hydrologist, Bureau of Reclamation, written commun., 2005) for years 1995-99. 
Table 11. Recharge volume per zone from irrigated crops for 1970-1999, Yuma area.

[No data for zone 17]

\begin{tabular}{|c|c|c|c|c|c|c|c|c|c|c|c|c|}
\hline Start date & End date & \multicolumn{11}{|c|}{ Recharge volume per zone (acre-feet) } \\
\hline $04 / 1970$ & 03/1971 & 165,684 & 17,214 & 24,071 & 76,389 & 90,717 & 23,172 & 20612 & 14,301 & 9,901 & 8,752 & 664,832 \\
\hline $10 / 1971$ & 03/1972 & 44,561 & 6,920 & 7,108 & 31,860 & 16,112 & 9,063 & 8,584 & 11,060 & 6,819 & 7,010 & 308,446 \\
\hline 04/1972 & $09 / 1972$ & 102,937 & 9,918 & 16,021 & 39,501 & 10,284 & 17,139 & 11,013 & 12,029 & 5,047 & 5,833 & 367,801 \\
\hline 04/1973 & 09/1973 & 106,969 & 5,464 & 16,668 & 60,651 & 14,984 & 20,972 & 6,359 & 12,056 & 3,449 & 7,441 & 340,624 \\
\hline $10 / 1973$ & 03/1974 & 45,296 & 7,453 & 6,647 & 29,645 & 15,357 & 11,568 & 9,139 & 12,492 & 8,355 & 8,119 & 307,391 \\
\hline 04/1974 & 09/1974 & 106,574 & 7,548 & 17,377 & 54,540 & 20,320 & 10,638 & 11,218 & 9,809 & 3,208 & 4,200 & 391,670 \\
\hline 10/1974 & 03/1975 & 43,078 & 5,463 & 6,282 & 24,746 & 10,874 & 11,738 & 7,264 & 10,032 & 7,944 & 7,687 & 282,561 \\
\hline 04/1975 & $09 / 1975$ & 99,722 & 8,785 & 15,922 & 71,926 & 20,440 & 25,239 & 11,530 & 7,718 & 7,233 & 7,746 & 380,122 \\
\hline 10/1976 & 03/1977 & 45,778 & 5,534 & 7,217 & 40,318 & 14,878 & 10,183 & 10,302 & 6,390 & 6,910 & 6,498 & 309,299 \\
\hline 04/1977 & 09/1977 & 95,093 & 4,684 & 15,404 & 17,802 & 16,242 & 13,745 & 5,193 & 4,858 & 0 & 4,507 & 365,601 \\
\hline 10/1977 & 03/1978 & 37,731 & 3,639 & 5,536 & 16,576 & 7,972 & 4,662 & 5,277 & 5,177 & 6,371 & 5,863 & 269,474 \\
\hline 04/1978 & 09/1978 & 105,125 & 5,745 & 14,914 & 35,435 & 17,371 & 17,161 & 7,543 & 1,947 & 0 & 6,196 & 357,251 \\
\hline $10 / 1978$ & 03/1979 & 47,322 & 4,370 & 3,861 & 14,775 & 12,983 & 6,508 & 9,048 & 5,568 & 6,905 & 7,496 & 263,321 \\
\hline 04/1979 & 09/1979 & 105,987 & 9,063 & 13,393 & 39,800 & 19,225 & 12,278 & 8,174 & 5,546 & 0 & 6,946 & 492,616 \\
\hline 10/1979 & 03/1980 & 53,572 & 7,140 & 5,616 & 38,382 & 13,830 & 7,101 & 4,839 & 7,510 & 6,938 & 8,018 & 385,145 \\
\hline 04/1980 & 09/1980 & 108,704 & 6,760 & 13,366 & 34,330 & 20,584 & 11,708 & 8,666 & 6,211 & 2,406 & 7,602 & 578,072 \\
\hline $10 / 1980$ & 03/1981 & 54,393 & 5,681 & 5,900 & 37,412 & 15,531 & 7,958 & 4,528 & 6,315 & 7,985 & 7,187 & 406,712 \\
\hline 04/1984 & 09/1984 & 89,402 & $-3,371$ & 12,886 & 27,912 & 17,843 & 1,052 & 859 & 1,095 & 0 & 2,994 & 554,646 \\
\hline $10 / 1984$ & $03 / 1985$ & 36,328 & 1,265 & 5,137 & 21,633 & 9,917 & 1,631 & 2,747 & 2,488 & 2,979 & 3,544 & 382,117 \\
\hline $04 / 1985$ & 09/1985 & 97,179 & 4,677 & 13,416 & 43,769 & 23,614 & 17,495 & 9,313 & 1,021 & 2,216 & 4,356 & 560,006 \\
\hline $10 / 1985$ & 03/1986 & 41,799 & 6,802 & 6,121 & 30,035 & 11,967 & 8,010 & 5,919 & 5,426 & 5,013 & 4,531 & 458,903 \\
\hline 04/1986 & 09/1986 & 99,210 & 10,753 & 13,423 & 35,040 & 21,928 & 16,485 & 5,691 & 7,044 & 3,001 & 6,059 & 539,354 \\
\hline $10 / 1986$ & 03/1987 & 44,361 & 4,414 & 5,823 & 30,789 & 13,495 & 7,973 & 4,258 & 7,368 & 5,576 & 6,240 & 388,313 \\
\hline 04/1987 & 09/1987 & 107,362 & 6,315 & 11,512 & 20,649 & 23,742 & 11,434 & 8,803 & 4,950 & 4,527 & 4,621 & 445,752 \\
\hline 10/1987 & 03/1988 & 56,113 & 7,504 & 4,751 & 46,862 & 12,852 & 7,356 & 5,860 & 5,441 & 6,897 & 5,157 & 388,480 \\
\hline $04 / 1988$ & 09/1988 & 132,578 & 4,376 & 11,043 & 28,306 & 20,792 & 20,735 & 7,204 & 3,223 & 2,059 & 4,993 & 417,432 \\
\hline $10 / 1988$ & 03/1989 & 72,348 & 13,307 & 8,484 & 49,536 & 8,436 & 8,218 & 8,944 & 4,883 & 13,130 & 4,889 & 312,129 \\
\hline 04/1989 & 09/1989 & 133,430 & 20,246 & 6,900 & 48,932 & 13,707 & 12,253 & 11,943 & 2,555 & 5,997 & 4,729 & 381,585 \\
\hline $10 / 1989$ & 03/1990 & 64,393 & 20,573 & 7,146 & 46,956 & 9,673 & 12,913 & 8,357 & 619 & 7,602 & 2,946 & 297,724 \\
\hline 04/1990 & 09/1990 & 148,813 & 8,434 & 11,694 & 49,129 & 23,563 & 18,620 & -922 & 6,177 & 0 & 10,965 & 361,857 \\
\hline $10 / 1990$ & 03/1991 & 61,412 & 13,694 & 4,375 & 20,715 & 10,050 & 6,045 & 2,890 & 4,814 & 6,879 & 5,433 & 296,095 \\
\hline 04/1991 & 09/1991 & 121,800 & 3,853 & 10,549 & 48,176 & 25,605 & 6,047 & 7,336 & 6,481 & 215 & 6,073 & 349,120 \\
\hline
\end{tabular}


Table 11. Recharge volume per zone from irrigated crops for 1970-1999, Yuma area-Continued.

\begin{tabular}{|c|c|c|c|c|c|c|c|c|c|c|c|c|}
\hline \multirow[b]{2}{*}{ Start date } & \multirow[b]{2}{*}{ End date } & \multicolumn{11}{|c|}{ Recharge volume per zone, in acre feet } \\
\hline & & 1,10 & 7,15 & 2 & 3,16 & 4,9 & 5,12 & 6,13 & 8 & 14 & 11 & 18 \\
\hline 10/1991 & 03/1992 & 48,288 & 10,480 & 3,689 & 22,027 & 10,641 & 6,470 & 463 & 6,007 & 5,179 & 6,689 & 287,818 \\
\hline 10/1992 & $03 / 1993$ & 35,877 & 7,607 & 3,399 & 34,477 & 3,307 & 8,443 & 1,588 & 5,072 & 5,536 & 7,401 & 311,324 \\
\hline 04/1993 & 09/1993 & 105,161 & 11,083 & 11,634 & 38,392 & 19,579 & 12,709 & 9,275 & 3,188 & 3,440 & 7,102 & 363,616 \\
\hline 04/1994 & 09/1994 & 106,214 & 6,084 & 9,428 & 44,140 & 16,964 & 14,422 & 7,503 & 3,570 & 4,552 & 7,657 & 290,218 \\
\hline 10/1994 & 03/1995 & 51,051 & 7,569 & 3,865 & 38,590 & 7,603 & 12,234 & 6,149 & 5,365 & 6,617 & 7,593 & 269,486 \\
\hline 04/1995 & 09/1995 & 109,890 & 10,348 & 11,620 & 62,440 & 22,929 & 14,286 & 8,165 & 4,754 & 2,186 & 8,349 & 338,073 \\
\hline $10 / 1995$ & 03/1996 & 53,592 & 6,750 & 4,684 & 54,040 & 9,849 & 9,613 & 4,895 & 4,507 & 3,442 & 6,098 & 285,783 \\
\hline 10/1997 & 03/1998 & 42,549 & 3,640 & 3,565 & 27,589 & 7,388 & 7,239 & -343 & 4,003 & 1,231 & 7,066 & 373,228 \\
\hline 04/1998 & 09/1998 & 97,700 & 11,050 & 8,714 & 56,783 & 22,599 & 12,160 & 6,896 & 1,498 & 0 & 7,702 & 409,273 \\
\hline $10 / 1998$ & 03/1999 & 48,654 & 7,650 & 5,790 & 48,950 & 10,291 & 8,916 & 2,208 & 2,917 & 1,610 & 9,094 & 378,395 \\
\hline 04/1999 & 09/1999 & 95,205 & 8,181 & 9,786 & 44,511 & 23,349 & 8,938 & 4,485 & 2,263 & 0 & 8,645 & 369,528 \\
\hline
\end{tabular}

Calculations of recharge in the Mexico portion of the model were less complicated because fewer data were available concerning the spatial distribution of applied irrigation and meteorological conditions. Diversion data at Morelos Dam, the surface flow across the SIB at San Luis, the cropped area in Mexicali Valley, and San Luis Valley (the flood plain portion of Mexico on the east side of the Colorado River) were obtained from the Western Water Bulletin of the International Boundary and Water Commission (IBWC) for 1970-99 (http://www.ibwc.state.gov/html/water accounting.html). Ground-water withdrawal data for 1970-98 for federal and private irrigation wells in Mexicali Valley and San Luis Valley also were obtained from IBWC.

Ground-water withdrawals in 1999 were assumed to be equal to those of 1998. Ground-water withdrawals for the San Luis Mesa well field are not included because this water is assumed to be consumed for municipal and industrial uses in San Luis, Sonora, Mexico. The total volume of water for recharge was calculated as

$$
R=0.3 \times W
$$

where

$$
\begin{gathered}
W=\text { the sum of the ground-water withdrawals by wells, } \\
\text { and surface water diverted at Morelos Dam and } \\
\text { the SIB. }
\end{gathered}
$$

Reclamation assumes that 30 percent of the applied water in Mexico becomes recharge-the remaining 70 percent is removed by ET. During the steady-state stress period from 1970 to $1971,801,155$ acre-ft of ground water was withdrawn by wells, 1,276,913 acre-ft of surface water was diverted at Morelos Dam, and 138,038 acre-ft of surface water was delivered at the SIB. The averaged cropped area for 1970-71 was 427,839 acres. Multiplying the total volume of water applied from 1970 to 1970 by 0.3 yields a recharge volume of 664,832 acre-ft for the Mexico portion of the model. Recharge volumes for 6-month transient stress periods from 1971 through 1999 were calculated in a similar manner. Recharge volumes from 1970 to 1999 are included in table 11 for zone 18 (located in Mexico). The maximum recharge, 578,072 acre-ft, occurred during the transient stress period in the model from April 1980 to September 1980. The minimum recharge, 263,321 acre-ft, occurred during the stress period from October 1978 to March 1979.

\section{Ground-Water Return Flow to the Colorado River}

Estimates of ground-water return flow to the Colorado River from below Laguna Dam to the NIB from 1972 to 1998 made by using surface-water budget methods indicate that ground-water generally was discharged to the Colorado River (fig. 26). Ground-water return flow was calculated as the difference between surface-water flow at streamflow-gaging station 09522000 Colorado River at NIB, above Morelos Dam, Arizona, and all gaged surface-water inputs to the Colorado River upstream to streamflow-gaging station 09429600 Colorado River below Laguna Dam,

Arizona-California. Although the measured surface-water flow rates vary annually owing to high flows during wet years, the average of ground-water return flow during years having 
low flow rates on the Colorado River was 79,000 acre-ft/yr (for years 1972-82, 1987-92, and 1994-96). This is similar to return flows calculated by using analyses of head at shallow piezometers along the same reach of the river (Loeltz and Leake, 1983). Large ground-water return flows for 1980 and 1994 might indicate significant releases of bank storage after high flows in 1979 and 1980 and during 1993. Surface-water flow past the NIB during 1984 and 1993 was less than flows into the reach, which may indicate periods of ground-water recharge. Recharge can occur because high river stages related to large flows might be greater than the water table along the river. Differences between inflows and outflows during 1983, 1985-86, and 1997-98 were near zero, indicating neither recharge nor discharge.

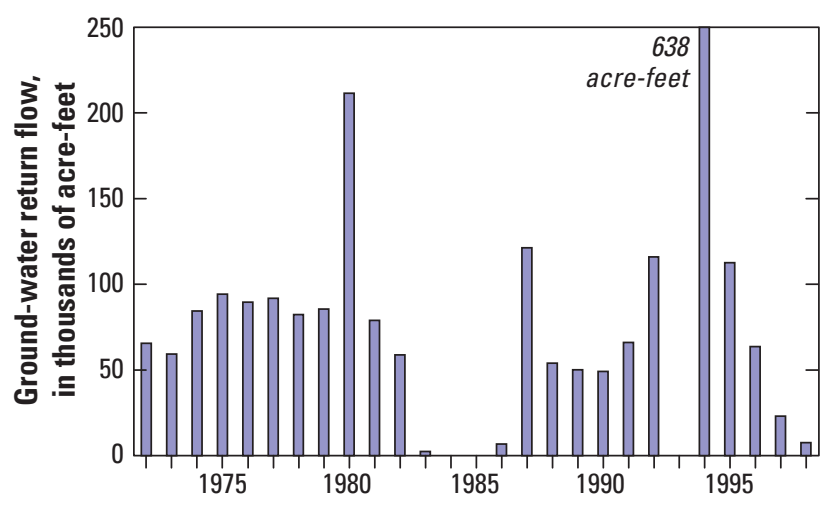

Figure 26. Ground-water return flow along the Colorado River between U.S. Geological Survey streamflow-gaging station 09522000 Colorado River at the northerly international boundary (NIB), above Morelos Dam, Arizona, and U.S. Geological Survey streamflow-gaging station 09429600 Colorado River below Laguna Dam, Arizona-California.

\section{Ground-Water Withdrawals}

Ground water has been withdrawn by using wells primarily for drainage of waterlogged land and to supplement surface-water supplies for irrigation (tables 12 and 13). From 1915 to 1990 , about 7,941,000 acre-ft of ground water was withdrawn in the Arizona portion of the Yuma area (Anning and Duet, 1994). Because surface water was used for irrigation for most areas, withdrawals for irrigation were negligible until ground water was used in 1915 in South Gila Valley for irrigation. The construction of the Yuma Mesa Division of the Gila Project resulted in additional water available for irrigation on Yuma Mesa beginning in the middle 1940s. Intense irrigation on Yuma Mesa resulted in substantial increases in ground-water levels on Yuma Mesa, which, in turn, resulted in radially outward flow from Yuma Mesa to Yuma and South Gila Valleys. Drainage wells were installed subsequently along the escarpment of Yuma Mesa to prevent water logging of irrigated lands in Yuma and South Gila Valleys. From 1915 to 1975, about one-half of the total withdrawals were for drainage (Wilkins, 1978). Data collected by Reclamation (William Greer, hydrologist, Bureau of Reclamation, written commun., 2005) indicate that drainage withdrawals for 1970-1999 are about 60 percent of the total withdrawals in the United States portion of the Yuma area (table 12).

Ground water was the main source for irrigation water in South Gila Valley before surface water was available to all of South Gila Valley by 1965. Surface water was first available in 1947 to areas adjacent to the Gila Gravity Main Canal (Olmsted and others, 1973). The first irrigation well was installed in 1915 in South Gila Valley. By 1925, about 1,000 acres were irrigated, and in 1955 about 9,700 acres were irrigated with ground water (Olmsted and others, 1973). The first nine drainage wells were installed in South Gila Valley in 1960 and 1961 to prevent water logging (William Greer, hydrologist, Bureau of Reclamation, written commun., 2006).

Since the 1980s, retirement of citrus fields and construction of housing developments in the Yuma area have resulted in increased ground-water withdrawals for domestic use. Although the quantity of ground water withdrawn for domestic use is substantially smaller than that used for irrigation, the portion of ground water used for domestic purposes likely will continue to increase.

Since 1980, water delivery requirements to Mexico have been supplemented by ground-water withdrawals within the 242 Wellfield. These withdrawals totaled 253,000 acre-ft from 1980 to 1999 - an average of 13,000 acre-ft/yr.

In general, ground-water withdrawals in Mexicali Valley, Mexico, supplemented surface-water supplies for irrigation. In 1955, the Mexican government concluded that 540,000 acres of irrigated land would require water in excess of the 1.5 million acre- $\mathrm{ft}$ of Colorado River water guaranteed to Mexico under the Treaty for the Utilization of Waters of the Colorado and Tijuana Rivers and of the Rio Grande of February 3, 1944 (Olmsted and others, 1973). The Mexican government approved the drilling of 281 wells in 1955 and an additional 100 wells in 1957. These wells were drilled in addition to 230 private wells drilled previously for irrigation (Olmsted and others, 1973).

Ground-water withdrawals compiled by Reclamation for the ground-water flow model for the entire Yuma area from 1970 to 1999 totaled 7,906,000 acre-ft, an average of 263,000 acre-ft/yr. Ground-water withdrawal data were collected from previous reports for the period 1915-90, and by Reclamation for 1970-99 (William Greer, hydrologist, Bureau of Reclamation; fig. 27, tables 12 and 13). The primary sources of data for Reclamation for 1970-94 Ground Water Status Reports (Bureau of Reclamation, 2004). After 1994, withdrawal rates for drainage wells were obtained from archives compiled by the Water Operations Group of the YAO. Some irrigation and municipal/industrial withdrawal data were obtained from Colorado River Decree Accounting records. Withdrawal data for Mexicali Valley, Mexico, were obtained from the IBWC offices in Yuma and in El Paso, Texas. 
Table 12. Ground-water withdrawals from 1970 to 1999 in the Yuma area and Mexicali Valley.

\begin{tabular}{|c|c|c|c|c|c|c|c|c|}
\hline \multirow[b]{3}{*}{ Year } & \multicolumn{8}{|c|}{ Ground-water withdrawals, in thousands of acre-feet } \\
\hline & \multicolumn{5}{|c|}{ United States } & \multicolumn{3}{|c|}{ Mexico } \\
\hline & Irrigation & Drainage & $\begin{array}{l}\text { From } 242 \\
\text { Wellfield }\end{array}$ & Miscellaneous & Calculated & Government & Private & $\begin{array}{c}\text { Sonora Mesa } \\
\text { irrigation }\end{array}$ \\
\hline 1970 & 74.53 & 164.07 & - & - & - & 568.21 & 232.95 & - \\
\hline 1971 & 81.28 & 175.07 & - & - & - & 559.94 & 201.87 & - \\
\hline 1972 & 75.31 & 205.16 & - & - & - & 562.66 & 241.46 & 1.52 \\
\hline 1973 & 83.84 & 212.17 & - & - & - & 535.65 & 236.13 & 90.22 \\
\hline 1974 & 79.99 & 199.26 & - & - & - & 597.21 & 242.84 & 135.56 \\
\hline 1975 & 80.04 & 201.01 & - & 1.24 & - & 534.69 & 221.31 & 92.13 \\
\hline 1976 & 68.01 & 184.17 & - & .8 & - & 493.13 & 202.63 & 89.31 \\
\hline 1977 & 65.13 & 184.28 & - & 1.03 & - & 513.48 & 186.09 & 128.8 \\
\hline 1978 & 60.38 & 177.87 & - & 1.54 & - & 474.51 & 129.7 & 104.37 \\
\hline 1979 & 66.5 & 184.6 & - & 1.31 & - & 423.88 & 141.58 & 27.79 \\
\hline 1980 & 74.61 & 196.01 & - & 1.3 & - & 393.72 & 130.71 & 16.99 \\
\hline 1981 & 72.75 & 185.46 & 17.76 & 1.99 & - & 511.24 & 176.03 & 142.47 \\
\hline 1982 & 61.4 & 170.06 & 22.73 & 2.92 & - & 471.52 & 162.57 & 147.74 \\
\hline 1983 & 57.29 & 157.89 & 3.23 & 9.55 & - & 319.35 & 120.81 & 18.6 \\
\hline 1984 & 50.15 & 185.5 & 3.12 & 9.63 & - & 333.21 & 125.82 & 7.32 \\
\hline 1985 & 53.73 & 178.95 & 2.51 & 10.36 & - & 403.16 & 124.34 & 30.23 \\
\hline 1986 & 55.63 & 190.64 & 4.72 & 10.34 & - & 378.57 & 117.63 & 10.74 \\
\hline 1987 & 58.59 & 164.18 & 6.01 & 10.65 & - & 444.15 & 104.95 & 41.66 \\
\hline 1988 & 62.08 & 181.02 & 4.62 & 6.64 & - & 487.23 & 123.57 & 127.31 \\
\hline 1989 & 76.21 & 179.27 & 34.08 & 11.03 & 0 & 527.45 & 155.9 & 139.72 \\
\hline 1990 & 36.57 & 112.77 & 34.11 & .94 & 138.87 & 516.98 & 155.34 & 136.08 \\
\hline 1991 & 55.59 & 120.35 & 33.69 & .72 & 129.34 & 453.96 & 152.61 & 124.22 \\
\hline 1992 & 47.14 & 94.08 & 26.39 & .66 & 94.54 & 354.43 & 121.88 & 65.97 \\
\hline 1993 & 42.43 & 117.74 & 6.55 & .83 & 94.74 & 221.67 & 71.83 & 5.87 \\
\hline 1994 & 42 & 85.81 & 19.23 & .81 & 95.28 & 292.78 & 94.85 & 61.84 \\
\hline 1995 & 54.95 & 128.86 & 10.98 & .79 & 105.08 & 319.29 & 103.45 & 39.6 \\
\hline 1996 & 33.25 & 116.32 & 6.18 & 1.2 & 78.38 & 362.04 & 117.3 & 66.77 \\
\hline 1997 & 33.25 & 118.12 & 6.18 & 1.2 & 74.64 & 362.04 & 117.3 & 65.7 \\
\hline 1998 & 30.06 & 134.99 & 5.19 & 1.18 & 75.44 & 319.29 & 103.45 & 0 \\
\hline 1999 & 28.84 & 134.15 & 4 & 1.36 & 75.66 & 319.29 & 103.45 & .24 \\
\hline
\end{tabular}


Table 13. Ground-water withdrawals for zones in the ground-water flow model from 1970 to 1999 in the Yuma area and Mexicali Valley.

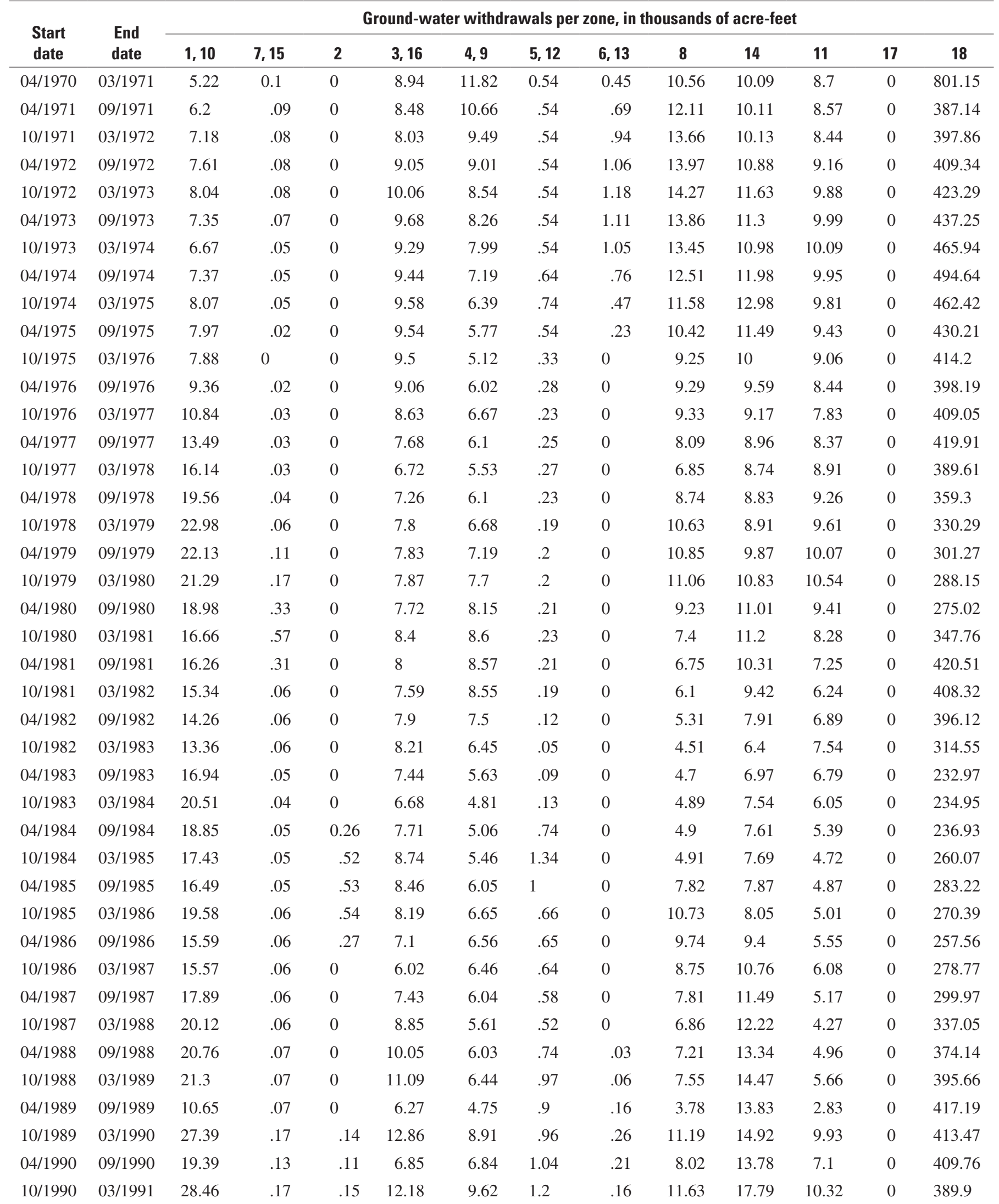


Table 13. Ground-water withdrawals for zones in the ground-water flow model from 1970 to 1999 in the Yuma area and Mexicali Valley-Continued.

\begin{tabular}{ccccccccccccccc}
\hline \multirow{2}{*}{$\begin{array}{c}\text { Start } \\
\text { date }\end{array}$} & $\begin{array}{c}\text { End } \\
\text { date }\end{array}$ & $\mathbf{1 , 1 0}$ & $\mathbf{7 , 1 5}$ & $\mathbf{2}$ & $\mathbf{3 , 1 6}$ & $\mathbf{4 , 9}$ & $\mathbf{5 , 1 2}$ & $\mathbf{6 , 1 3}$ & $\mathbf{8}$ & $\mathbf{1 4}$ & $\mathbf{1 1}$ & $\mathbf{1 7}$ & $\mathbf{1 8}$ \\
\hline $04 / 1991$ & $09 / 1991$ & 22.02 & .14 & .12 & 11.72 & 8.22 & .8 & .1 & 9.11 & 13.15 & 8.07 & 0 & 370.04 \\
$10 / 1991$ & $03 / 1992$ & 21.59 & .14 & .11 & 11.43 & 8.01 & .54 & .05 & 8.82 & 11.41 & 7.83 & 0 & 322.55 \\
$04 / 1992$ & $09 / 1992$ & 19.28 & .13 & .11 & 9.79 & 7.22 & .48 & .06 & 7.98 & 12.18 & 7.07 & 0 & 275.05 \\
$10 / 1992$ & $03 / 1993$ & 20.58 & 0.14 & 0.11 & 10.24 & 7.03 & 0.43 & 0.08 & 8.41 & 13.1 & 7.46 & 0 & 213.58 \\
$04 / 1993$ & $09 / 1993$ & 19.93 & .14 & .11 & 9.93 & 6.93 & .41 & .1 & 8.25 & 13.11 & 7.3 & 0 & 152.1 \\
$10 / 1993$ & $03 / 1994$ & 20.88 & .15 & .11 & 9.55 & 6.87 & .38 & .12 & 8.53 & 13.56 & 7.57 & 0 & 190.01 \\
$04 / 1994$ & $09 / 1994$ & 20.65 & .14 & .12 & 10.96 & 7.36 & .49 & .14 & 8.54 & 12.84 & 7.57 & 0 & 227.92 \\
$10 / 1994$ & $03 / 1995$ & 24.29 & .16 & .13 & 14.5 & 8.5 & .6 & .17 & 9.93 & 12.26 & 8.8 & 0 & 231.28 \\
$04 / 1995$ & $09 / 1995$ & 18.73 & .13 & .11 & 10.76 & 6.85 & .48 & .16 & 7.75 & 10.86 & 6.86 & 0 & 234.63 \\
$10 / 1995$ & $03 / 1996$ & 16.83 & .13 & .09 & 8.73 & 5.98 & .36 & .14 & 6.88 & 10.11 & 6.1 & 0 & 255.55 \\
$04 / 1996$ & $09 / 1996$ & 15.82 & .15 & .09 & 8.67 & 5.92 & .27 & .11 & 6.54 & 9.42 & 5.8 & 0 & 276.47 \\
$10 / 1996$ & $03 / 1997$ & 16.22 & .18 & .08 & 8.58 & 6.09 & .41 & .08 & 6.63 & 9.16 & 5.88 & 0 & 265.23 \\
$04 / 1997$ & $09 / 1997$ & 15.33 & .18 & .09 & 7.96 & 6.28 & .23 & .06 & 6.34 & 9.08 & 5.62 & 0 & 253.99 \\
$10 / 1997$ & $03 / 1998$ & 16.04 & .18 & .08 & 7.33 & 6.61 & .3 & .05 & 6.55 & 9.5 & 5.81 & 0 & 234.41 \\
$04 / 1998$ & $09 / 1998$ & 15.26 & .18 & .09 & 7.19 & 6.3 & .33 & .03 & 6.31 & 9.62 & 5.59 & 0 & 214.84 \\
$10 / 1998$ & $03 / 1999$ & 16.03 & .18 & .08 & 7.13 & 6.31 & .34 & .02 & 6.55 & 9.96 & 5.81 & 0 & 214.84 \\
$04 / 1999$ & $09 / 1999$ & 7.9 & .09 & 0 & 3.62 & 3.22 & .18 & .01 & 3.27 & 5.04 & 0 & 0 & 214.84 \\
\hline
\end{tabular}

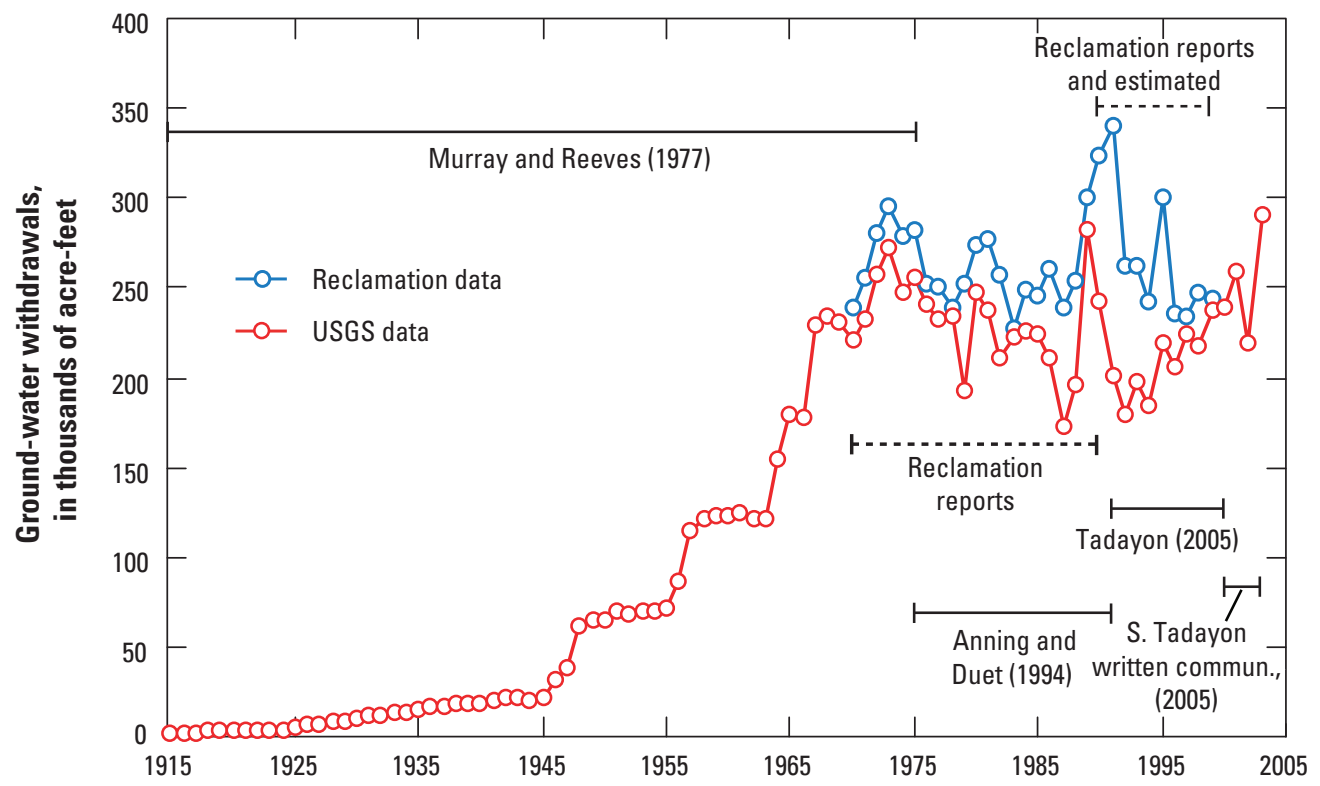

Figure 27. Regional ground-water withdrawals and data sources for the Yuma area, 1915-1999.

Ranges of dates for U.S. Geological Survey estimates are indicated by solid lines, and dates by U.S. Bureau of Reclamation are indicated by dashed lines. 
After 1989, many agricultural, municipal, and industrial withdrawals were no longer reported in the Decree Accounting Report. Such withdrawals were calculated for the ground-water flow model by using data from 1979 to 1989. Summer and winter withdrawal rates corresponding to the transient stress periods were calculated for each year. An average summer and winter withdrawal rate for 1979-89 was calculated for each model cell having withdrawals during those years. Some model cells during that period had multiple wells. Cells that had reported withdrawals after 1989 were assigned the reported rate. Withdrawals were calculated for model cells, not individual wells. Withdrawals were calculated for the cells that did not have reported withdrawals after 1989, but had a nonzero average summer or winter withdrawal rate from 1979 to 1989. The ground-water withdrawal rate $Q$ for such a cell without data was calculated for each stress period by

$$
Q=R_{\text {average }} \times \text { sum }_{S P} / \text { sum }_{\text {season }},
$$

where

$$
\begin{aligned}
& R_{\text {average }}= \begin{array}{c}
\text { the average summer or winter rate for that } \\
\text { cell from } 1979 \text { to } 1989 \text { that must be } \\
\text { nonzero, }
\end{array} \\
& \text { sum }_{S P}= \begin{array}{r}
\text { the sum of withdrawals for the stress period } \\
\text { for all cells which had nonzero average for } \\
\text { the particular season for 1979-89 (summer } \\
\text { or winter), and }
\end{array} \\
& \text { sum }_{\text {season }}=\begin{array}{l}
\text { the sum of the average withdrawals for all } \\
\text { cells used to calculate } \text { sum }_{S P} \text { for } 1979-89 \\
\text { for corresponding summer or winter } \\
\text { seasons. }
\end{array}
\end{aligned}
$$

Calculations of ground-water withdrawals (fig. 27) by Reclamation for 1970-90 are similar to other estimates published in reports (for example, Murray and Reeves, 1977; Anning and Duet, 1994; Tadayon, 2005; Saeid Tadayon, hydrologist, U.S. Geological Survey, written commun., 2005). Estimates from 1990 to 1999 are consistent with values from previous years and projection methods for wells without reported values are feasible. By using Reclamation's methods, analyses for unreported withdrawals in additional years could be done based on past conditions and supported by new reported withdrawal data.

\section{Additional Data Needs}

The analyses presented in this report were based on compilation of existing data and targeted collection of new geophysical and geochemical data. The results of these analyses have identified several priorities for additional data compilation and new data collection.

\section{Compilation and Analyses of Data from Previous Studies}

The HFM can be improved by analysis of additional data that constrain extent and thickness of HGUs. Analyses of gravity data are useful for identifying changes in subsurface density that indicate spatial variations in bedrock amongst lesser-density sediments. Widespread gravity data, collected as part of the USGS studies of the Yuma area in the 1960s, can be analyzed by using 3D gravity models. These models can provide new interpretations of the impermeable bedrock structures buried under much of Yuma Mesa. Seismicreflection surveys done by the General Atomic Division of General Dynamics in 1966 can provide additional data to constrain the bedrock models. The eastern extent of the coarse-gravel unit is uncertain because of limited data. Although the coarse-gravel unit probably is unsaturated in these areas, additional information about the extent of the unit may indicate the depositional history and related hydraulic properties of unconsolidated sediments that constitute the aquifer. New borehole-lithology data in these areas could help define the thickness and extent of the gravels in these areas.

Further compilation and analysis of information on ground-water conditions also would help in the development of improved ground-water management tools. Any refinements to water-budget components will help in constructing a more representative ground-water flow model. Specific information needs include ground-water withdrawal data for the area, including Mexicali Valley; water use by phreatophytes; history of development of irrigation and drainage systems; groundwater level change data from predevelopment conditions to present; and historical Colorado River stage data.

Most of the historical water-chemistry data analyzed in this report were from 1984 and later. Incorporation of earlier data will improve understanding of how ground-water development primarily has affected water chemistry. Data presented in Olmstead and others (1973), other historical data in NWIS, and data collected for public health purposes from local and county agencies can be incorporated into the analyses.

\section{Data Collection and Analyses to Improve Understanding of the Flow System}

Specific new data-collection efforts could help the model simulate the flow system more accurately. Several efforts could improve the representation of the hydrogeologic framework in the ground-water flow model of the Yuma area. Additional gravity measurements will help in defining the bedrock high on Yuma Mesa and adjacent hills. High density contrasts along the margins of the bedrock high indicate steep features associated with poorly defined vertical faulting. Additional gravity measurements would provide higher data resolution needed to locate buried fault surfaces.

The results of the stable isotope and ${ }^{3} \mathrm{H}$ data presented in this report indicate that these data can provide useful indicators of the source and age of ground water in the Yuma area. Stable isotope data would be particularly valuable to 
better determine the source of water in eastern Yuma Mesa and central Yuma Valley. Additional ${ }^{3} \mathrm{H}$ data will provide a more detailed delineation of recent (post-1950) and older ground water. In areas where more exact age determinations are needed, ${ }^{3} \mathrm{He}$ should be measured.

Analysis of pesticides and their derivatives could help define areas affected by such agricultural applications and better characterize the extent of the ground-water mound. As part of such analysis, it would be necessary to compile information about the historic applications of pesticides in the Yuma area.

On the basis of the results presented in this report, as well as the results from studies in other areas, additional depth-dependent sampling could provide additional important information on the 3D geochemistry and ground-water flow in the aquifer system. This analysis would require sampling in wells within key areas and wells having relatively long sections open to the aquifer system.

The ground-water flow model (William Greer, hydrologist, Bureau of Reclamation, written commun., 2005) simulates conditions through 1999. Calibration of the model to predevelopment conditions, which represents the ground-water system prior to the development of the mound, would require additional data, including historical ground-water and surfacewater data and water use by phreatophytes. To update the model to reflect current conditions, all stresses, flow rates, and specified stages will need to be supplemented with newer data. Specific data items to be extended include stages of surfacewater features, recharge from agriculture, ground-water withdrawals, and water use by phreatophytes. The intervals over which time-varying model results are needed for specific management objectives must be considered in updating the transient model input data sets.

\section{Compilation of Data for Management Modeling}

In order to develop a useful ground-water and surfacewater management model in Phase 3 of the proposed USGS-Reclamation cooperative study, it will be necessary to incorporate essential information about Reclamation's current facilities, operational procedures, and monitoring systems. This would include review of the plans and capabilities of Reclamation's Supervisory Control and Data Aquisition (SCADA) system. Also, it will be necessary to identify management objectives to optimize the engineering, hydraulic, regulatory, and institutional constraints on Reclamation's operation of the surface-water/ground-water system in the Yuma area.

\section{Summary of Phase 1 Analysis and Concepts for Water Management}

This report documents the results of Phase 1 of the USGS program to provide science support to Reclamation for the management of surface-water and ground-water resources in the Yuma area. Phase 1 includes reassessment of the hydrogeologic framework of the study area; quantification of ground-water levels, movement, and storage changes; analysis of the water chemistry of key areas of the Yuma area; and review of several water-budget components. The results of this work provide a firm basis to undertake Phase 2: evaluating and refining the existing Reclamation ground-water flow model; and Phase 3: linking the model with optimization techniques to explicitly address the key management questions facing Reclamation in the Yuma area.

The main hydrogeologic units (HGUs) were reevaluated and incorporated into a new hydrogeologic framework model (HFM). The HGUs, which generally follow the divisions of Olmstead and others (1973), are the Bouse Formation and older rock units, undifferentiated lower units [including the transition zone and the wedge zone of Olmstead and others (1973)], coarse-gravel unit, lower fill unit, clay A, middle fill unit, clay B, and upper fill unit. The HFM integrates results from previous studies and new interpretations based on recently compiled geophysical data and lithologic logs. The coarse-gravel unit is the main water-bearing unit in the Yuma area and has a distinct signature in resistivity logs that is present in Yuma Valley and under Yuma Mesa. The top of the coarse-gravel unit has been redefined in the HFM to include discontinuities related to downcutting by the Colorado River under Yuma Valley and Yuma Mesa. Clay A, the lower clay unit, is in Yuma Valley and extends beneath the western edge of Yuma Mesa. New lithologic logs compiled for this study indicate that clay A extends further to the west in Yuma Valley than previously mapped. Clay B, the upper clay unit, underlies western Yuma Mesa. New data compiled for this study suggest that clay B extends to the southerly international boundary (SIB), which is further south than previously mapped.

Analyses of ground-water levels show that major changes have taken place in the flow system since predevelopment time. The Colorado River, once a source of water to the aquifer, is now a sink. Ground-water levels generally are higher than they were prior to development, except near the SIB. Ground-water levels near the SIB generally are lower because of ground-water withdrawals by wells in the United States and Mexico at the 242 Wellfield. Water flows radially away from a ground-water mound under Yuma Mesa. A volume of 600,000 to 800,000 acre-ft of water is stored in the mound within an extent defined by this study. Gradients are generally to the south, but are toward the Colorado River and Mexicali Valley in Yuma Valley. Future analyses of groundwater conditions will benefit from continued monitoring of water levels and data from any new wells in areas having sparse information, such as the Upper Mesa. Consideration of connected ground-water and surface-water features is important in constructing water-level maps and interpreting directions of ground-water movement. Information on which canal reaches are hydraulically connected to the aquifer could provide additional constraints on water-level maps.

A large quantity of water-quality data were compiled from Reclamation and the USGS. These data were merged into a single database and incorporated into a GIS for spatial analysis. The major-ion composition of these wells was 
delineated by geographic area (South Gila Valley, Yuma Mesa, Yuma Valley, and along the SIB). New water-quality samples were collected from 12 wells and 8 canals or drains. These new samples were analyzed for major ions, nutrients, stable isotopes of oxygen-18 and deuterium, tritium $\left({ }^{3} \mathrm{H}\right)$, and carbon-14 ( ${ }^{14} \mathrm{C}$; along with $\mathrm{C}^{13} / \mathrm{C}^{12}$ ratios). Depth-dependent sampling was conducted at well YM-10. The highest total dissolved-solids concentration was measured at well SG-709 $(3,020 \mathrm{mg} / \mathrm{L})$; the highest nitrate was measured at well SG-10r (8 mg/L).

Isotope data provide information on sources of recharge and ground-water age. The lightest (most negative) values of ${ }^{18} \mathrm{O}$ and $\mathrm{D}$ (for example, water in well 242-2) indicate water that was recharged entirely by the Colorado River. The heaviest (least negative) values of ${ }^{18} \mathrm{O}$ and $\mathrm{D}$ (for example, water in well 242-22, USMC CADC, and Mesa del Sol \#35) indicate that the water was recharged locally from the Upper Mesa and adjacent hills. The the ratio between deuterium and oxygen-18 from water samples from several wells (for example, water from SG-10r, YM-10, and Fortuna Pond) indicates the effects of evaporation. The source of these waters likely is Colorado River water used for irrigation. Tritium data were used to distinguish between relatively young (recharged after 1950) and older water. Relatively recent water was found in wells in the valleys or near the edge of Yuma Mesa. Older water was found away from the river (for example, wells 242-10, 242-22, USMC CADC, and Mesa del Sol \#35). ${ }^{14} \mathrm{C}$ data indicate that water in wells $242-10$ and 242-22 along the SIB east of the Colorado River is at least several thousand years old.

The water-budget analysis in this study focused on documenting and analyzing the values and methods used in the existing Reclamation ground-water flow model. Waterbudget components analyzed include recharge from excess irrigation, evapotranspiration by crops and phreatophytes, and ground-water withdrawals by wells. The main source of recharge within the current model is applied irrigation water. These values were calculated from detailed land use and crop efficiency data. Estimates of ET by phreatophytes may be improved by incorporating recent innovations in linking remote sensing and meteorological data.

The results presented in this report are important for water management in the Yuma area. The updated HFM, developed by using EarthVision software, can be incorporated directly into a revised version of Reclamation's groundwater flow model (William Greer, hydrologist, Bureau of Reclamation, written commun., 2005). The sensitivity of the flow-model results to changes in the HFM, such as new top altitudes of the coarse-gravel unit and broader extents of clay A and clay B, can be evaluated. This will facilitate testing aspects of the hydrogeology of the Yuma area that are most crucial for consideration in management decisions, and will help set priorities for new data collection. The improved understanding of the sources of recharge and ages of water provided by the isotopic geochemical analysis, along with the water-budget review, needs to be incorporated into the ground- water flow model in order to accurately assess the impacts on alternative future management scenarios. Refinement of Reclamation's ground-water flow model is proposed as Phase 2 of the Reclamation-USGS cooperative study.

Phase 3 of the study would develop a formal management model that directly links the ground-water flow model with optimization techniques to specifically address Reclamation's surface-water and ground-water management challenges in the Yuma area. For example, such a management model could help identify the most efficient strategies for meeting flow and salinity requirements, meeting water-delivery targets, and maintaining ground-water levels below specified thresholds under different climatic and infrastructure scenarios. The development of this management model is a logical extension of Reclamation's ground-water flow model (William Greer, hydrologist, Bureau of Reclamation, written commun., 2005). The hydrogeologic and geochemical results presented in this report, coupled with targeted additional data collection, will help assure that the management model will incorporate an adequate representation of the complexity of the Yuma ground-water flow system.

\section{References Cited}

Abbott, P.L., 1999, The rise and fall of San Diego: San Diego, California, Sun Belt Publications, 231 p.

American Public Health Association, 1998, Standard methods for the examination of water and wastewater (20th ed.); Washington, D.C., American Public Health Association, American Water Works Association, and Water Environment Federation, p. 3-37-3-43.

Anning, D.W. and Duet, N.R., 1994, Summary of groundwater conditions in Arizona, 1987-1990: U.S. Geological Survey Open-File Report 94-476, 2 sheets.

Biehler, S., Kovach, R.L., and Allen, C.R., 1964, Geophysical framework of northern end of Gulf of California structural province, in Marine geology of California-A symposium: Memoirs, American Association Petroleum Geologists, v. 3, p. 126-143.

Brown, R.H., Harshbarger, J.W., and Thomas, H.E., 1956, Analysis of basic data concerning ground water in the Yuma area, Arizona: U.S. Geological Survey Open-File Report 56-16, 117 p.

Bureau of Reclamation, U.S. Department of the Interior, 2004, Lower Colorado River Accounting System: U.S. Bureau of Reclamation Demonstration of Technology Report for calendar year 2002, 174 p.

Clifford, H.J., Bergen, F.W., and Spear, S.G., 1997, Geology of San Diego County: Legacy of the land: San Diego, California, Sun Belt Publications, 175 p. 
Coplen, T.B., 1994, Reporting of stable hydrogen, carbon, and oxygen isotopic abundances: Pure and Applied Chemistry, v. 66, p. $273-276$.

Donahue, D.J., Linick, T.W., and Jull, A.J.T., 1990, Ratio and background corrections for accelerator mass spectrometry radiocarbon measurements: Radiocarbon, v. 32, p. 135-142.

Dynamic Graphics, Inc., 1999, Getting started with EarthVision 5: Alameda, California, Dynamic Graphics, Inc., $130 \mathrm{p}$.

Eberly, L.D. and Stanley, Jr., T.B., 1978, Cenozoic stratigraphy and geologic history of southwestern Arizona: Geological Society of America Bulletin v. 89, p. 921-940.

Ekwurzel, B., Schlosser, P., Smethie, W.M., Plummer, L.N., Busenburg, E., Michel, R.L., Weppernig, R., and Stute, M., 1994, Dating of shallow groundwater: comparison of the transient tracers ${ }^{3} \mathrm{H} /{ }^{3} \mathrm{He}$, chlorofluorocarbons, and ${ }^{85} \mathrm{Kr}$ : Water Resources Research, v. 30, no. 6, p. 1,693-1,708.

Erie, L.J., French, O.F., and Harris, K., 1965, Consumptive use of water by crops in Arizona: Tucson, Arizona University Technical Bulletin 169, 44 p.

Faires, L.M., 1993, Methods of analysis by the U.S. Geological Survey National Water Quality LaboratoryDetermination of metals in water by inductively coupled plasma-mass spectrometry: U.S. Geological Survey OpenFile Report 92-634, 28 p.

Fenneman, N.M., 1931, Physiography of western United States: New York, McGraw-Hill, 534 p.

Fenneman, N.M., 1946, Physical divisions of the United States, with Characteristics [of the sections], by Fenneman, N.M., and Johnson, D.W.: U.S. Geological Survey 1:7,000,000 scale map.

Fishman, M.J., ed., 1993, Methods of analysis by the U.S. Geological Survey National Water Quality LaboratoryDetermination of inorganic and organic constituents in water and fluvial sediments: U.S. Geological Survey OpenFile Report 93-125, 217 p.

Fishman, M.J., and Friedman, L.C., 1989, Methods for determination of inorganic substances in water and fluvial sediments: U.S. Geological Survey Techniques of WaterResources Investigations, book 5, chap. A1, 545 p.

Fontes, J.C., 1985, Some considerations on ground water dating using environmental isotopes: Memoirs of the $18^{\text {th }}$ Congress of the International Association of Hydrogeologists, Cambridge, p. 139.

Izbicki, J.A., 2004, A small-diameter sample pump for collection of depth-dependent samples from production wells under pumping conditions: U.S. Geological Survey Fact Sheet FS 2004-3096, 2 p.
Izbicki, J.A., Christensen, A.H., and Hanson, R.T., 1999, U.S. Geological Survey combined well-bore flow and depthdependent water sampler: U.S. Geological Survey Fact Sheet FS 196-99, 2 p.

Jacob, C.E., 1960, Groundwater and drainage of Yuma Valley and contiguous areas; Consultant's report to Yuma County Water User's Association by C.E. Jacob and Associates, Los Angeles, Calif., 50 p., with 9 appendixes (A through I) and 2 supplements (1A and 1B) separately bound.

Jensen, M.E., 1998, Coefficients for vegetative evapotranspiration and open water evaporation for the Lower Colorado River accounting system, October 1998: Marvin E. Jensen, Consultant, 1207 Springwood Dr., Fort Collins, CO 80525-2850. Available from the Bureau of Reclamation Boulder Canyon Operations Office in Boulder City, Nev.

Johrenwend, J.C., Gray, Floyd, and Miller, R.J., 2001, Processed thematic mapper satellite imagery for selected areas within the U.S.-Mexico Borderlands: U.S. Geological Survey Open-File Report 00-309, Version 1.0, 47 p.

Jull, A.J.T., Burr, G.S., McHargue, L.R., Lange, T.E. , Lifton, N.A., Beck, J.W., Donahue D.J., and Lal, D., 2004, New frontiers in dating of geological, paleoclimatic and anthropological applications using accelerator mass spectrometric measurements of $14 \mathrm{C}$ and $10 \mathrm{Be}$ in diverse samples: Global and Planetary Change, v. 41, p. 309-323.

Loeltz, O.J. and Leake, S.A., 1983, A method for estimating ground-water return flow to the Lower Colorado River in the Yuma area, Arizona and California: U.S. Geological Survey Water-Resources Investigations Report 83-4220, $86 \mathrm{p}$.

Mattick, R.E., Olmsted, F.H., and Zohdy, A.A.R., 1973, Geophysical studies in the Yuma area, Arizona and California: U.S. Geological Survey Professional Paper 726-D, $36 \mathrm{p}$.

Michel, R.L., 1989, Tritium deposition in the continental United States, 1953-1989: U.S. Geological Survey WaterResources Investigations Report 89-4072, 46 p.

Michel, R.L. and Schroeder, R.A., 1994, Use of long-term ${ }^{3} \mathrm{H}$ records from the Colorado River to determine timescales for hydrologic processes associated with irrigation in the Imperial Valley, California: Applied Geochemistry, v. 9, p. 387-401.

Mook, W.G., and van der Plicht, J., 1999, Reporting ${ }^{14} \mathrm{C}$ activities and concentrations: Radiocarbon, v. 41, no. 3, p. 227-239.

Murray, C.R., and Reeves, E.B., 1977, Estimated use of water in the United States, 1975: U.S. Geological Survey Circular $765,39 \mathrm{p}$. 
Nagler, P.L, Scott, R.L, Westenburg, Craig, Cleverly, J.R., Glenn, E.P., Huete, A.R., 2005, Evapotranspiration on western U.S. rivers estimated using the Enhanced Vegetative Index from MODIS and data from eddy covariance and Bowen ratio flux towers: Remote Sensing of Environment 97, p. 337-351.

Nichols, J., Eichinger, W., Cooper, D., Prueger, J., Hipps, L., Neale, C., 2004, Comparison of evaporation estimation methods for a riparian area: University of Iowa IIHR hydroscience and engineering technical report No. 436, $46 \mathrm{p}$.

Olmsted, F.H., Loeltz, O.J., and Irelan, Burdge, 1973, Geohydrology of the Yuma area, Arizona and California: U.S. Geological Survey Professional Paper 486-H, 227 p.

Ostlund, H.G., Craig, H., Broecker, W.S., and Spencer, D., 1987, Geosecs Atlantic, Pacific, and Indian Ocean expeditions, Shorebased Data and Graphics: v. 7 , p. 7-19.

Ostlund, H.G. and Dorsey, H.G., 1977, Rapid electrolytic enrichment and hydrogen gas proportional counting of ${ }^{3} \mathrm{H}$, in low-radioactivity measurements and applications: Proceedings of the International Conference on Low-Radioactivity Measurements and Application, October 6-10, 1975, The High Tatras, Czechoslovakia, p. 55-60.

Owen-Joyce, S.J., Wilson, R.P., Carpenter, M.C., and Fink, J.B., 2000, Method to identify wells that yield water that will be replaced by water from the Colorado River downstream from Laguna Dam in Arizona and California: U.S. Geological Survey Water-Resources Investigations Report 00-4085, 31 p., 3 pl.

Patten, E.P., Jr., 1977, Analog simulation of the groundwater system, Yuma, Arizona: U.S. Geological Survey Professional Paper 486-I, 10 p.

Radtke, D.B., White, A.F., Davis, J.V., Wilde, F.D., eds., April 1998, Dissolved oxygen: U.S. Geological Survey Techniques of Water-Resources Investigations, book 9, chap. A6., section 6.2, accessed March 21, 2005, at http://pubs.water.usgs.gov/wri9A6/.

Rosanski, K., Araguas-Araguas, L., and Gonfiantini, R., 1993, Isotopic patterns in modern global precipitation: Continental isotope indicators of climate: American Geophysical Union Monograph.

Schroeder, R.A., Setmire, J.G., and Densmore, J.N., 1991, in Drainage and irrigation, W.F. Ritter, ed., Use of stable isotope, tritium, soluble salts, and redox-sensitive elements to distinguish ground water from irrigation water in the Salton Sea basin: American Society of Civil Engineers, p. 524-531.
Struzeski, T.M., DeGiacomo, W.J., and Zayhowski, E.J., 1996, Methods of analysis by the U.S. Geological Survey National Water Quality Laboratory-Determination of dissolved aluminum and boron in water by inductively compled plasma-atomic emission spectrometry: U.S. Geological Survey Open-File Report 96-149, 17 p.

Sweet, C.L., 1952, Report on drainage, Valley Division, Yuma Project, Arizona: U.S. Bureau of Reclamation, 73 p.

Tadayon, Saeid, 2005, Water withdrawals for irrigation, municipal, mining, thermoelectric power, and drainage uses in Arizona outside of active management areas, 1991-2000: U.S. Geological Survey Scientific Investigations Report 2004-5293, 38 p.

Tipton and Kalmbach, Inc. and Jacob, C.E., 1956, Groundwater and drainage of Yuma Mesa and Yuma Valley, Report for the U.S. Department of the Interior, v. 1, 78 p.

U.S. Geological Survey, variously dated, National field manual for the collection of water-quality data: U.S. Geological Survey Techniques of Water-Resources Investigations, book 9, chaps. A1-A9, available online at http://water.usgs.gov/owq/FieldManual/.

Western Region Climate Center, 2005, accessed 2005 at http://www.wrcc.dri.edu/.

Wilkins, 1978, Maps showing ground-water conditions in the Yuma area, Yuma county, Arizona-1975: U.S. Geological Survey Water Resources Investigations Report 78-62, 3 maps. 
Appendices A-C 
This page left blank intentionally. 


\section{Appendix A}

The regional complete Bouguer gravity field is well defined by several hundred gravity stations (http://paces.geo.utep.edu/gdrp/; fig. 28). The primary features of the field include an arch-shaped region of high gravity associated with the northwest-trending Gila Mountains, along the Gila River from the Gila and Laguna Mountains to Yuma Mesa, and southeast of Yuma Mesa to the SIB. A prominent northwest-trending gravity low lies between the southeasttrending arms of the gravity high. The large magnitude of the gravity low, as much as $60 \mathrm{mGal}$, implies that thousands of feet of low-density alluvial deposits likely occur within a structural basin between outcrops of high-density crystalline rock in the Gila Mountains and Yuma Mesa. The gravity high near the Gila River likely is associated with a relatively shallowly-buried broad basement saddle separating the structural basin to the southeast and basins to the north. The extent of the gravity high near Yuma Mesa indicates that shallow bedrock may be much more extensive than is evident from the small amount of crystalline rock outcrop and few wells that penetrate crystalline rocks near Yuma. Improved definition of the horizontal extent and thickness of low-density alluvial deposits can be obtained by applying gravity models to the available gravity data and by using available subsurface information for control.

\section{3/4-Dimensional Density-Distribution Models}

Models of the subsurface density distribution were constructed to simulate the gravity field near three gravity profiles that cross Yuma Mesa (fig. 28). Gravity data indicate that the structural features in the area are strongly 3 dimensional; that is, the slope of the surface of the features varies with azimuth. Any model should include simulation of the 3-dimensional nature of the feature. Software is available to construct a fully 3 -dimensional simulation; however, a 2 3/4-dimensional approach was applied by using GM-SYS software to produce a simple approximation of the 3-dimensional feature. 2-dimensional profile models simulate the gravitational field produced by prisms that extend an infinite distance and at right angles from either side of the profile. Structural features ideally suited for simulation by using a 2-dimensional approach include a nondipping and nonfolded, monocline, syncline, or anticline. $2 \frac{1}{2} 2$-dimensional profile models simulate the gravitational field produced by prisms that are strongly linear, but extend a finite distance and at right angles from either side of the profile. Features ideally suited for simulation by using a $2 \frac{1}{2}$-dimensional approach include a dipping or folded structure, monocline, syncline, anticline, or oval-shaped alluvial basin. Simulation of $23 / 4$-dimensional prisms allows for simulation of profiles that cross structural features at oblique angles. Simulation of the predominantly northwest trending structural features in the Yuma area is best accomplished by using a $23 / 4$-dimensional approach. Details of the extents of features away from the profiles were simulated by using between 12 and 14 $23 / 4$-dimensional prisms along each profile.

Control information indicating the altitude of the top of crystalline rock include outcrops of crystalline rock on Yuma Mesa and in the Gila Mountains, dozens of well logs that indicate the minimum thickness of alluvial deposits, several well $\log$ s that indicate the top of crystalline rock, and top of the crystalline rock from seismic reflection data (Eberley and Stanley, 1978). A single 24.9-mile (40-km) north-south profile, D-D' (fig. 29), begins at the All-American Canal, crosses through the city of Yuma, and ends at the SIB. Two subparallel 24.9-mile (40-km) east-west profiles, E-E' (fig. 30) and F-F' (fig. 31), cross the area from west of Yuma Mesa to east of the Gila Mountains and cross the profile D-D'. Crystalline rock altitude control for profile D-D' includes well logs that indicate the minimum altitude of the top of crystalline rock near Yuma Mesa and seismic reflection data south of Yuma Mesa. Crystalline rock altitude control for profile E-E' includes outcrops of crystalline rock at Yuma Mesa and the Gila Mountains and seismic reflection data near the Gila Mountains. Crystalline rock altitude control for profile F-F' includes well logs that indicate the top of crystalline rock near Yuma Mesa, outcrops in the Gila Mountains, and seismic reflection data near the Gila Mountains.

Control information was used to approximate the angle and extents of prisms from each transect and to determine the average density of low-density alluvial sediments that best simulates the correct altitude of the top of crystalline rock (assumed density of $2.67 \mathrm{~g} / \mathrm{cm}^{3}$ ) at each control site. A density of $2.35 \mathrm{~g} / \mathrm{cm}^{3}$ for alluvial deposits best simulates the top of crystalline rock at each of the control sites. 


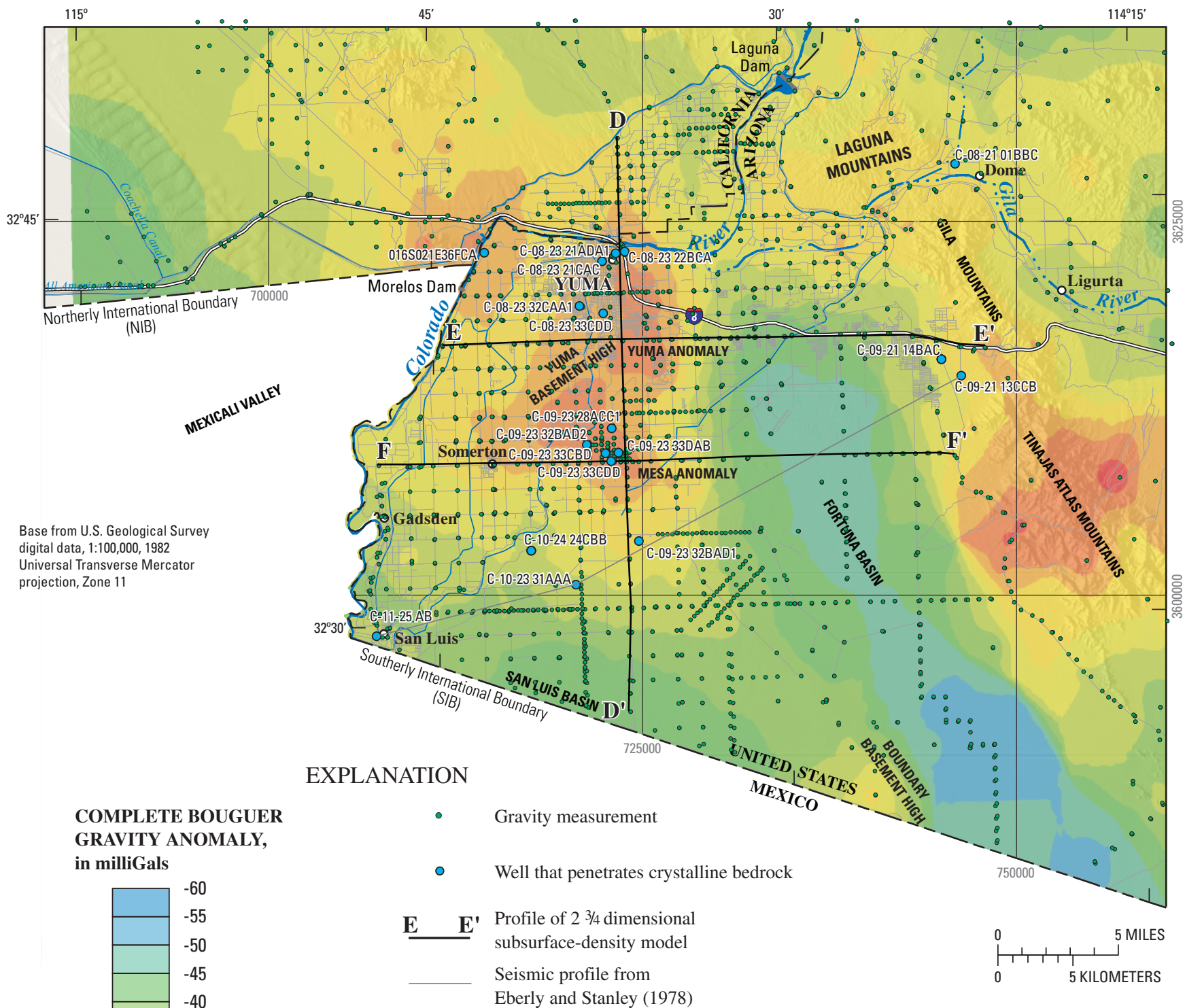

Figure 28. Complete Bouguer gravity anomaly, gravity measurement sites, wells that penetrate crystalline bedrock, and a seismic profile in the Yuma area, from Eberly and Stanley (1978), used to construct subsurface density-distribution profiles D-D', E-E', and F-F', shown in figures 29,30 , and 31 , respectively. 

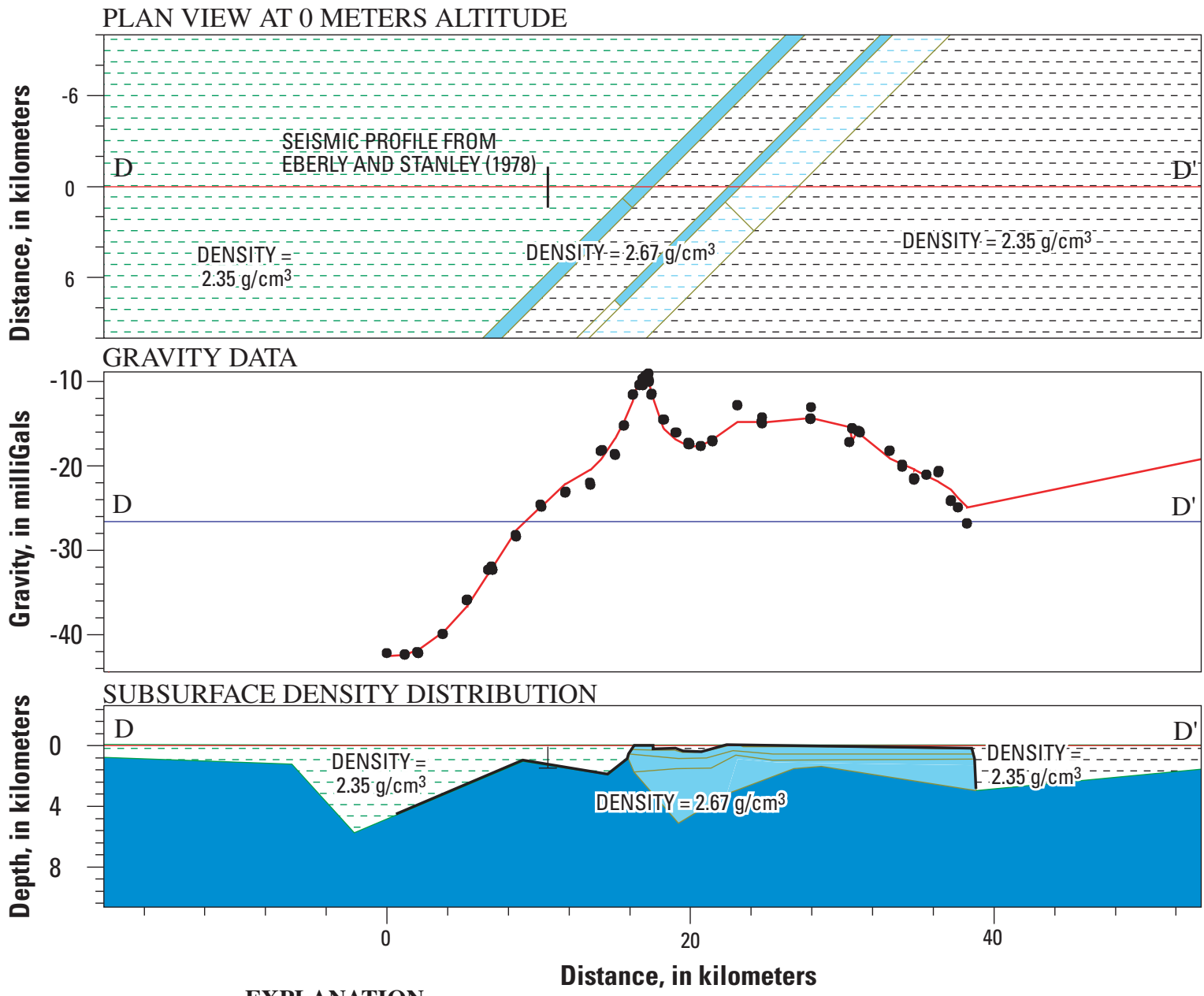

EXPLANATION

Top elevation of crystalline bedrock

- measured gravity value

2 dimensional crystalline rock (PRISM)

— simulated gravity value

$23 / 4$ dimensional crystalline rock (PRISM)

2 dimensional alluvial deposit (PRISM)

2 3/4 dimensional alluvial deposit (PRISM)

Figure 29. Subsurface density distribution along profile D-D' that extends in a north-south direction from the AllAmerican Canal, through the city of Yuma, to the southerly international border. 

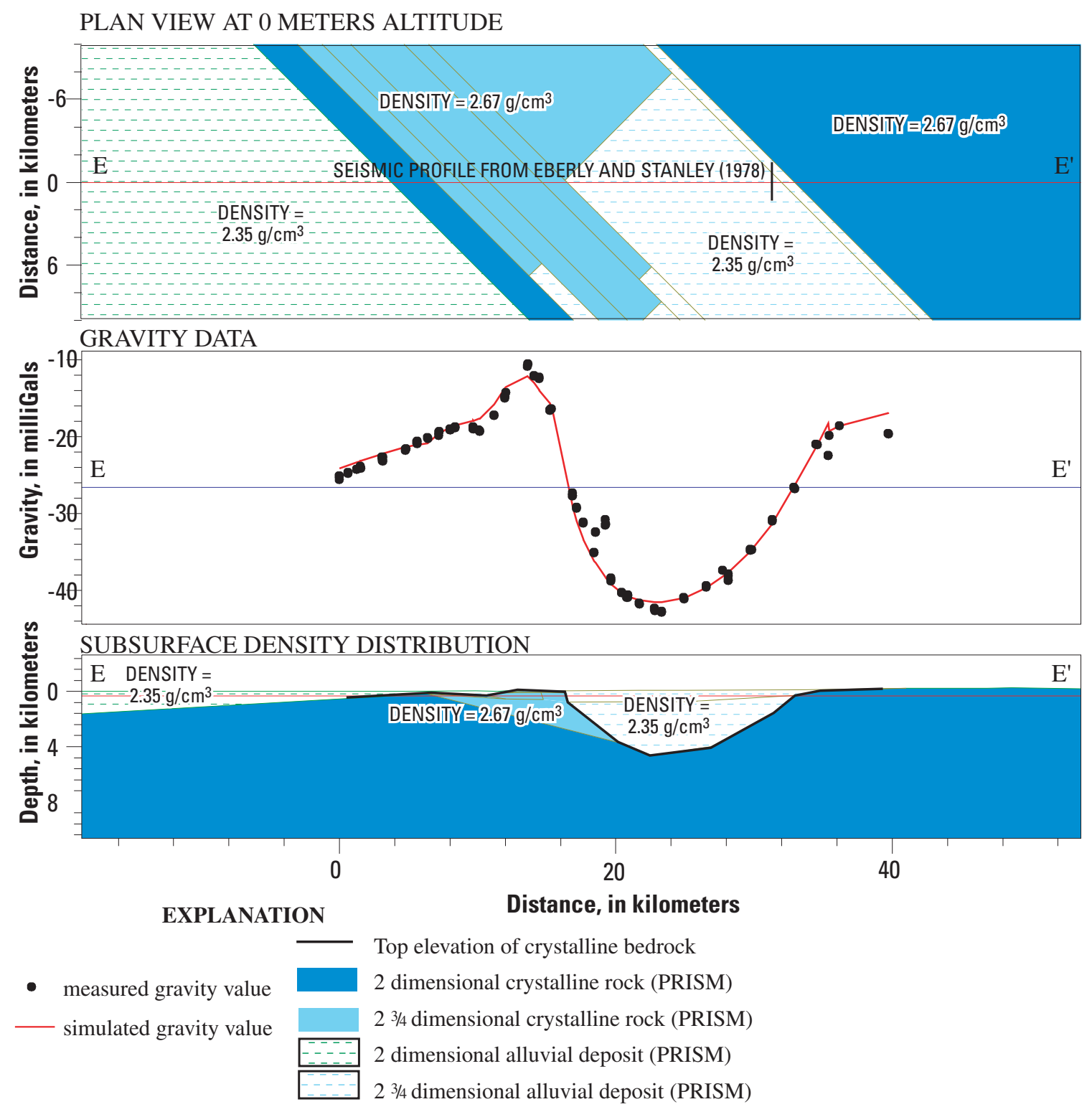

Figure 30. Subsurface density distribution along profile E-E' that extends in an east-west direction from Yuma Valley to the Gila Mountains. 

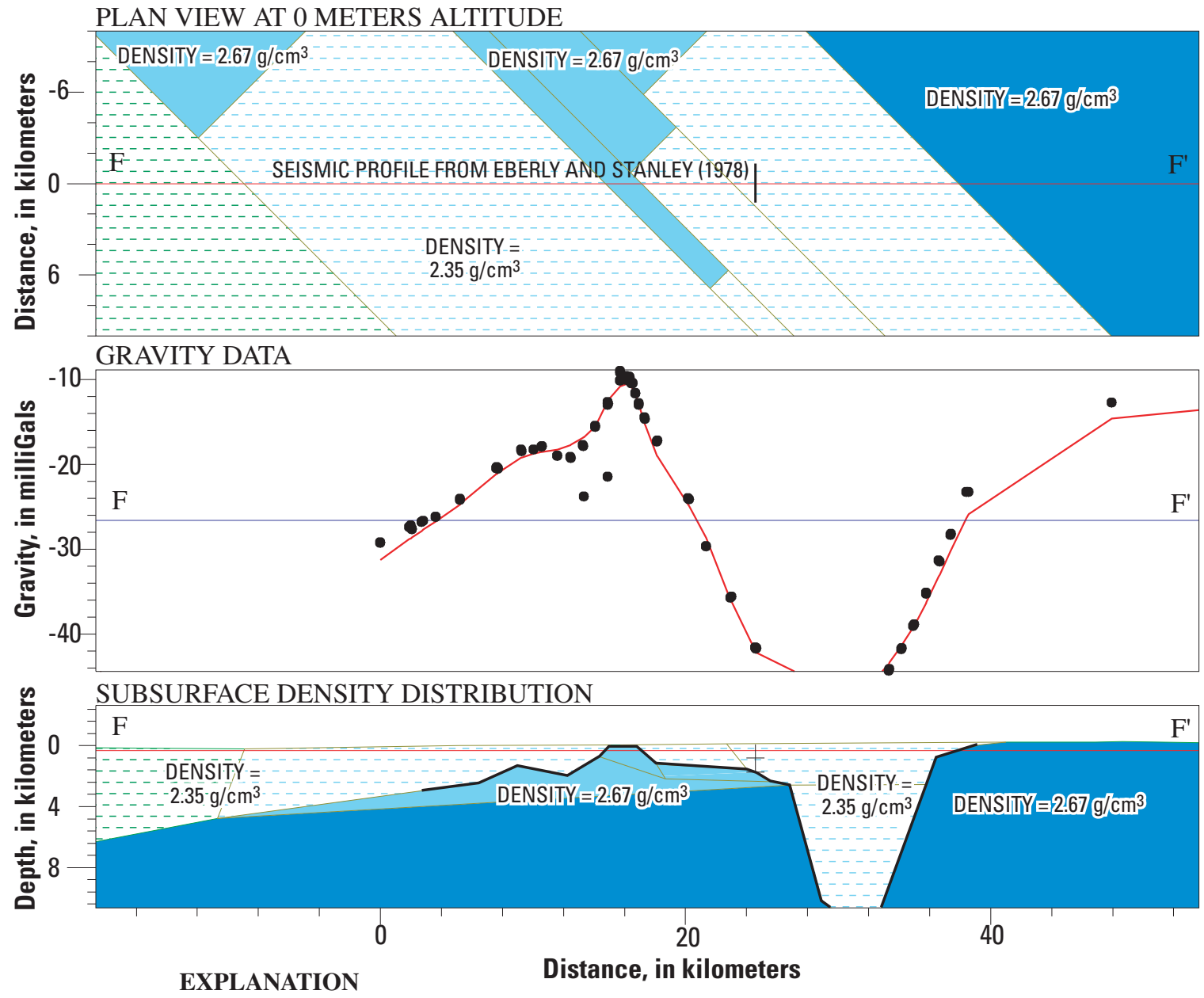

Top elevation of crystalline bedrock

- measured gravity value

2 dimensional crystalline rock (PRISM)

simulated gravity value

$23 / 4$ dimensional crystalline rock (PRISM)

2 dimensional alluvial deposit (PRISM)

$23 / 4$ dimensional alluvial deposit (PRISM)

Figure 31. Subsurface density distribution along profile F-F' that extends in an east-west direction from Yuma Valley to the Gila Mountains. 


\section{Density Model Results}

Geologic structure along each of the profiles was represented similarly in the models. Figures 29, 30, and 31 show the prisms used to simulate the subsurface density along profiles D-D', E-E', and F-F', respectively. The upper panel of each figure is a plan view of the nearest 6.21 miles $(10 \mathrm{~km})$ to the profile showing the orientation and lateral extent of prisms that intersect an altitude of $0 \mathrm{ft}$ (sea level). The middle panel shows the observed Bouguer gravity and simulated gravity at each station along the profile. The lower panel shows the lateral and vertical extent of each prism along the profile with no vertical exaggeration. The structural high of crystalline rock near Yuma Mesa and adjacent alluvial deposits was treated as multiple $23 / 4$-dimensional prisms with a primary long-axis orientation of strike N. $45^{\circ} \mathrm{W}$. Features at great depth and distance from Yuma Mesa were treated as 2-dimensional prisms that strike N. $45^{\circ} \mathrm{W}$. The 2-dimensional prisms in the upper and lower panels of figures 29, 30, and 31 are indicated by dark blue solids and lines representing crystalline rock and alluvial deposits, respectively. 2 3/4-dimensional prisms are displayed by light blue solids and lines representing crystalline rock and alluvial deposits, respectively.

The gravity field along Profile D-D' was simulated by using a steep sided, 13.7-mile (22-km) wide, 2 3/4-dimensional structural high, the base of which is irregular at depths of 1.25 miles to 2.5 miles (fig. 29). Shallow depths to crystalline rock of less than $1,000 \mathrm{ft}$ occur throughout the width of the structural high. Depth to crystalline rock is more than $4,900 \mathrm{ft}$ east and west of the structural high.
The gravity field along E-E' was simulated by using a $23 / 4$-dimensional structural high, the base of which slopes gradually from shallow depths on the west to the east margin of the structural high, east of which the base slopes steeply eastward toward the base of the alluvial basin on the east (fig. 30). Depth to crystalline rock is more than $650 \mathrm{ft}$ across most of the profile. Shallow depths to crystalline rock of less than $330 \mathrm{ft}$ occur only along a 2.5-mile-wide region between 7.5 and 10 miles on the $X$ axis on figure 30 . The bottom of the alluvial basin that lies to the west of Yuma Mesa slopes gradually from the land surface near crystalline rock outcrops at the center of the profile, to more than $1 \mathrm{~km}$ west of the station at $0 \mathrm{ft}$ distance on the $\mathrm{X}$ axis. To the east of the crystalline rock outcrop, the crystalline rock slopes downward at an angle of nearly 45 degrees to a depth of nearly 3 miles at a distance of about 3.75 miles. The crystalline rock surface slopes less steeply upward toward the Gila Mountains.

The gravity field along F-F' was simulated by using a $23 / 4$-dimensional structural high, the base of which slopes gradually from about 2.5 miles deep at the east margin to about 3 miles deep at the west margin of the structural high (fig. 31). Depth to crystalline rock is more than 1.25 miles across most of the profile. Shallow depths to crystalline rock of less than $330 \mathrm{ft}$ occur only along a 1.25-mile-wide region near 10 miles on the $\mathrm{X}$ axis. The bottom of the alluvial basin that lies to the west of Yuma Mesa slopes gently to the west to about 3.75 miles deep at about -11 miles on the $\mathrm{X}$ axis. To the east of the structural high outcrop, the crystalline rock slopes steeply downward to a depth of nearly 3,300 ft at about 18 miles on the $\mathrm{X}$ axis, east of which the surface slopes steeply upward toward the Gila Mountains. 


\section{Appendix B}

\section{Yuma Mesa}

Seismic refraction, time-domain electromagnetic (TDEM), magnetic, and very low frequency (VLF) surveys were conducted on Yuma Mesa (fig. 32). The driller's log for abandoned well $\mathrm{CH}-20 \mathrm{YM}$ indicates shallow granite bedrock at a depth of $47 \mathrm{ft}$. In addition, the trace of the Algodones Fault is thought to transect this area. Surface expression of the fault is exhibited about 7.5 miles to the southeast on the Upper Mesa and the fault trends along strike N. $40^{\circ} \mathrm{W}$. and is thought to extend to a point on the Colorado River south of Pilot Knob.

Two north-south oriented seismic refraction surveys were done to image the shallow bedrock starting from a point north of the intersection of East County 16th Street and the $4^{\text {th }}$ Avenue Extension (fig. 33). The first survey was $817 \mathrm{ft}$ long and consisted of two spreads of 48 geophones placed at $9.84-\mathrm{ft}$ spacings. The second spread was established to allow for a 12-geophone, 108-ft overlap with the first spread. Data from 20 shot points were obtained by using a 20-lb sledge hammer and a metal plate as an acoustic source. The second survey was conducted at the same location as the first survey. To image a longer distance, however, the geophone spacing was increased to $19.7 \mathrm{ft}(6 \mathrm{~m})$. The survey again consisted of two spreads of 48 geophones with the second spread configured to allow for a 10-geophone, 177-ft (54-m) overlap. This configuration resulted in a total survey length of $1,673 \mathrm{ft}(510 \mathrm{~m})$. Data for the second survey were obtained from 22 shot points by using explosive charges as an acoustic source.

Results from the first survey show a 2-dimensional (x-z) velocity structure that consists of a relatively low velocity layer 30-60 ft thick (fig. 33). The velocities gradually increase with depth along a relatively narrow interval and increase sharply at depths of 50-115 ft. These results are consistent with the lithology that is documented in the driller's log for well CH-20YM, which shows $47 \mathrm{ft}$ of unconsolidated sediments overlying granite (quartz-monzonite) bedrock. The low-velocity layer is interpreted as being associated with the unconsolidated alluvial deposits and the high-velocity layer is associated with the granite bedrock. The transitional interval along which the velocities gradually increase is interpreted as being caused by increasing moisture conditions associated with the water table. The driller's log for well CH-20YM indicates a depth to water of $30 \mathrm{ft}$ in 1996.

Results from the second seismic refraction survey are similar to those from the first survey (fig. 33). These results, however, show a more horizontally extensive zone of shallow bedrock with steep sloping sides. The bedrock is overlain by about $33 \mathrm{ft}$ of unconsolidated alluvial deposits and 15-100 ft of variably saturated alluvium.
TDEM methods were also used to make vertical depth profiling measurements to image bedrock at this same site. Measurements were made along intersecting transects YMTDEM-1 and YMTDEM-2 (fig. 34). A 131- by 131-ft transmitter loop and centrally located 32.8 - by $32.8 \mathrm{ft}$ receiver loop were used for all measurements. Measurements were made at 328-ft spacings along both transects. Data obtained from these measurements were used to develop twodimensional cross sections of the electrical resistivity structure of the subsurface.

The TDEM surveys show along YMTDEM-1 indicate a less resistive zone at a depth of about $50 \mathrm{ft}$ (fig. 34). This less resistive zone is horizontally discontinuous and absent between stations 5 and 6 along the profile. Within this zone, more resistive values are observed. The less resistive zone is interpreted to indicate the water table. The more resistive zone is interpreted to indicate shallow, quartz-monzonite bedrock at an altitude higher than the water table.

Results from measurements taken along YMTDEM-2 are similar to the results obtained along YMTDEM-1 (fig. 34). These results are not surprising, given that these transects cross and generally cover the same area. A very thin, horizontally discontinuous, less-resistive layer is indicated at the southeast end (station 1) of YMTDEM-2. This less resistive layer is interrupted by a more resistive, horizontally and vertically extensive unit that fades further to the northwest near station 7. At the termination of the more resistive unit, another wedge of less-resistive material begins to emerge. This other less-resistive layer is $50 \mathrm{ft}$ deep at both ends of the transect and thickens to the northwest. The horizontal extent of the more resistive unit along this transect is much greater than the horizontal extent observed along YMTDEM-1. These results indicate that the shallow bedrock unit might increase in size along the northwestern direction.

To delineate the trace of the Algodones Fault, magnetic and VLF surveys were conducted near abandoned well CH-20YM. The survey lines were oriented perpendicular to the suspected trace of the fault system, which prior studies found to have a strike of N. $40^{\circ} \mathrm{W}$. (Olmsted and others, 1973; fig. 34). For the magnetic surveys, a proton-precession magnetometer was used to measure the total magnetic field along a 2,296-ft transect oriented approximately at strike of $\mathrm{N}$. $45^{\circ}$ E. (fig. 34). Measurements were made at 32.8-ft intervals. VLF measurements of phase, quadrature, field, and tilt were made by using two frequencies: 24.0 kilohertz $(\mathrm{kHz})$ from Cutler, Maine, and $24.8 \mathrm{kHz}$ from Jim Creek, Washington. Measurements also were recorded at 32.8-ft intervals along the same transect line that was used for the magnetic survey. Results from the magnetic and VLF surveys were inconclusive because the data showed no significant anomalies or coherent trends that could be related to structural features associated with the Algodones Fault system. 


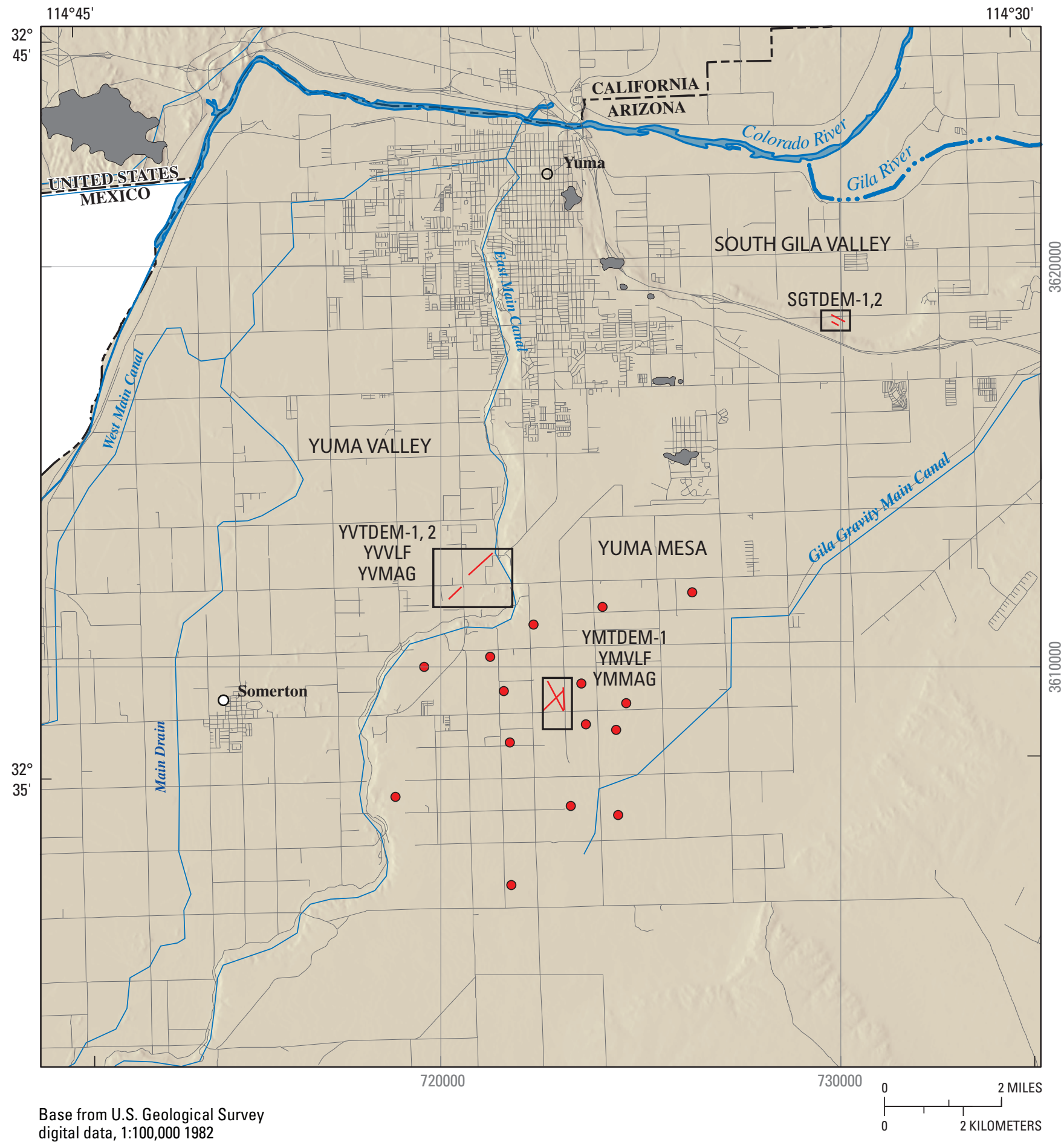

digital data, 1:100,000 1982

Universal Transverse Mercator

projection, Zone 11

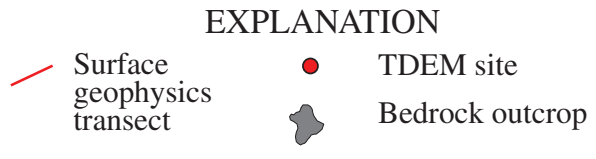

NOTE: Transects are shown in figures $33-36$

Figure 32. Surface geophysical surveys at Yuma Valley and Yuma Mesa. 


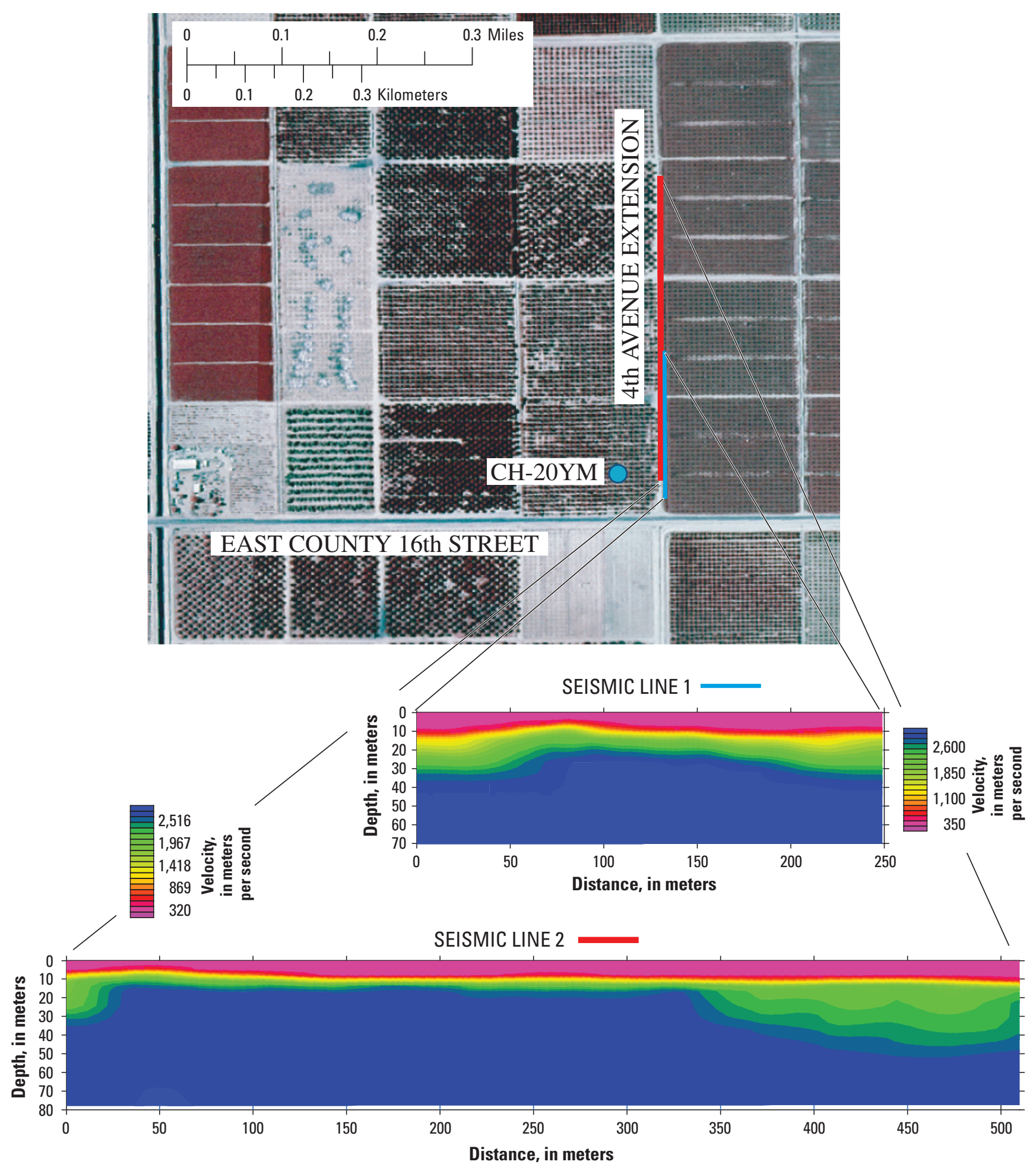

Figure 33. Seismic surveys along transects Seismic Line 1 and Seismic Line 2 at Yuma Mesa near East County 16 th Street and $4^{\text {th }}$ Avenue extension. 


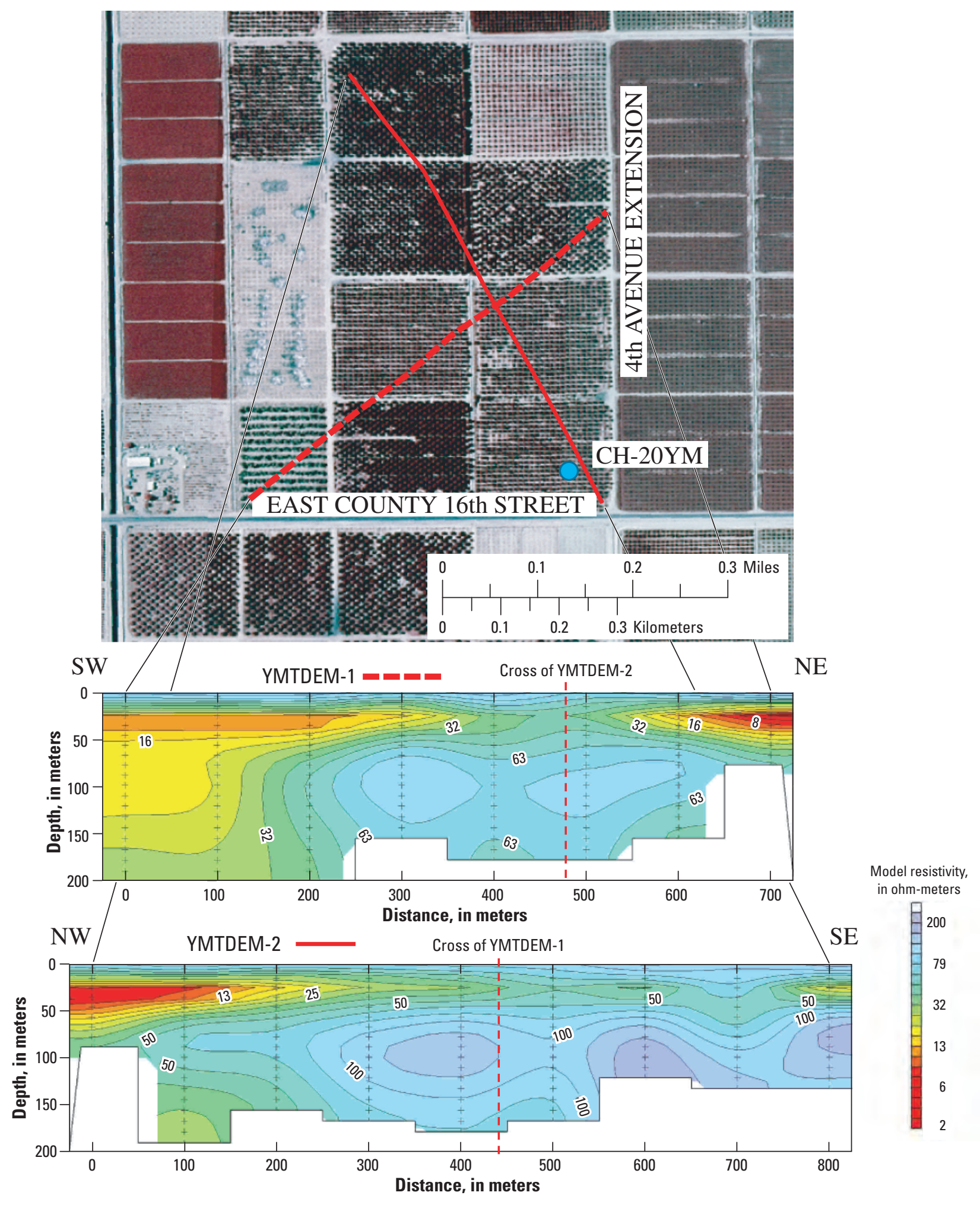

Figure 34. Time-domain electromagnetic surveys YMTDEM-1 and YMTDEM-2 at Yuma Mesa near East County 16th Street and $4^{\text {th }}$ Avenue extension. 
TDEM vertical depth soundings were made at 14 locations on Yuma Mesa (fig. 32). These soundings were made with the intent of gaining a rough understanding of the variance of depth to bedrock across the area. As stand-alone measurements, however, these soundings did not provide enough information to make determinations of depth to bedrock. These data sets, when combined with additional geophysical measurements, might be useful in determining depth to bedrock in future studies.

\section{Yuma Valley}

Geophysical surveys were conducted at two sites in Yuma Valley to delineate the trace of the Algodones Fault system and to verify the existence of fine-grained soil units (fig. 35). TDEM, VLF, and magnetic surveys were made along two transects that strike N. $45^{\circ} \mathrm{E}$. in agricultural fields in sections 20 and 30 of township 9 range 23. The TDEM surveys comprise a vertical-sounding profile measurement by using a 131- by 131-ft transmitter loop and a centrally located measurement by using a 32.8 - by 32.8 -ft receiver loop. Measurements were made at 328-ft intervals along the 2,624-ft northern transect and the 1,312-ft southern transect. VLF measurements of phase, quadrature, field, and tilt measurements of the vertical magnetic gradient and total magnetic field were made at 32.8-ft intervals along each transect.

Inversion of the TDEM data collected along the two transects does not exhibit a resistivity structure indicative of elevated soil-moisture conditions and/or the existence of finegrained soil units with an elevated soil moisture. At the time of the surveys, one of the fields recently had been harvested, soil in the other was recently turned over, and neither field appeared to show elevated soil moisture conditions.

The results of the VLF and magnetic surveys indicated no anomalies or coherent trends that could be related to structural features associated with the trace of the Algodones Fault system.

\section{Well Site CH-21YM}

A single TDEM vertical depth measurement was performed at observation well CH-21YM. This site was chosen as a calibration site to test the utility of the TDEM method to resolve the water table and shallow bedrock. The measurement was made by using a 131- by 131-ft transmitter loop and a centrally located 32.8 - by 32.8 -ft receiver loop.

On the basis of the results of a 1-dimensional layeredmodel inversion, a less-resistive layer is indicated at a depth of about $46 \mathrm{ft}$ (fig. 34). This layer is interpreted to be the water table. The depth to water was $72.2 \mathrm{ft}$ when the well was installed in 1966. The significant 26-ft water-level change is attributed to inaccuracies in the inverted solution and to ground-water mounding associated with intense irrigation activities since the well was installed.
The drillers' log for well CH-21 YM indicates bedrock at $267.7 \mathrm{ft}$. The transmitter/receiver configuration used to make the TDEM vertical depth sounding at this site did not provide sufficient late-time data to resolve structures at depths greater than $230 \mathrm{ft}$. As a result, no interpretation was made with respect to the presence of the granite bedrock.

\section{South Gila Valley}

Two TDEM surveys (SGTDEM-1, SGTDEM-2) in an area of South Gila Valley known as "South Gila Cove" (fig. 36), were done to image fine-grained soil units thought to be responsible for ground-water perching and poorly drained conditions in the area. Both surveys were conducted by using a 131- by 131-ft transmitter loop and a centrallylocated 32.8- by 32.8-ft receiver loop. Measurements were made at 328-ft intervals along each transect. Along transect SGTDEM-1, measurements were made at four stations, and measurements were made at three stations along transect SGTDEM-2.

Results from data obtained along transect SGTDEM-1 indicate different soil conditions than at SGTDEM-2 (fig. 36). Results from SGTDEM-1 show less resistive areas [about $10 \mathrm{ohm}-\mathrm{m}(\Omega-\mathrm{m})]$ at the surface and more resistive areas (about $20 \Omega$-m) below about $50 \mathrm{ft}$ (fig. 36). These resistivity values do not indicate fine-grained materials. The slight increase in resistivity, with depth, is attributed to a decrease in water content. Results at SGTDEM-2 show a less-resistive layer extending from the surface to a depth of about $65 \mathrm{ft}$. This suggests a very fine-grained soil unit having high water content (perhaps saturated). These results are consistent with the hydrologic conditions known to exist in this area. 


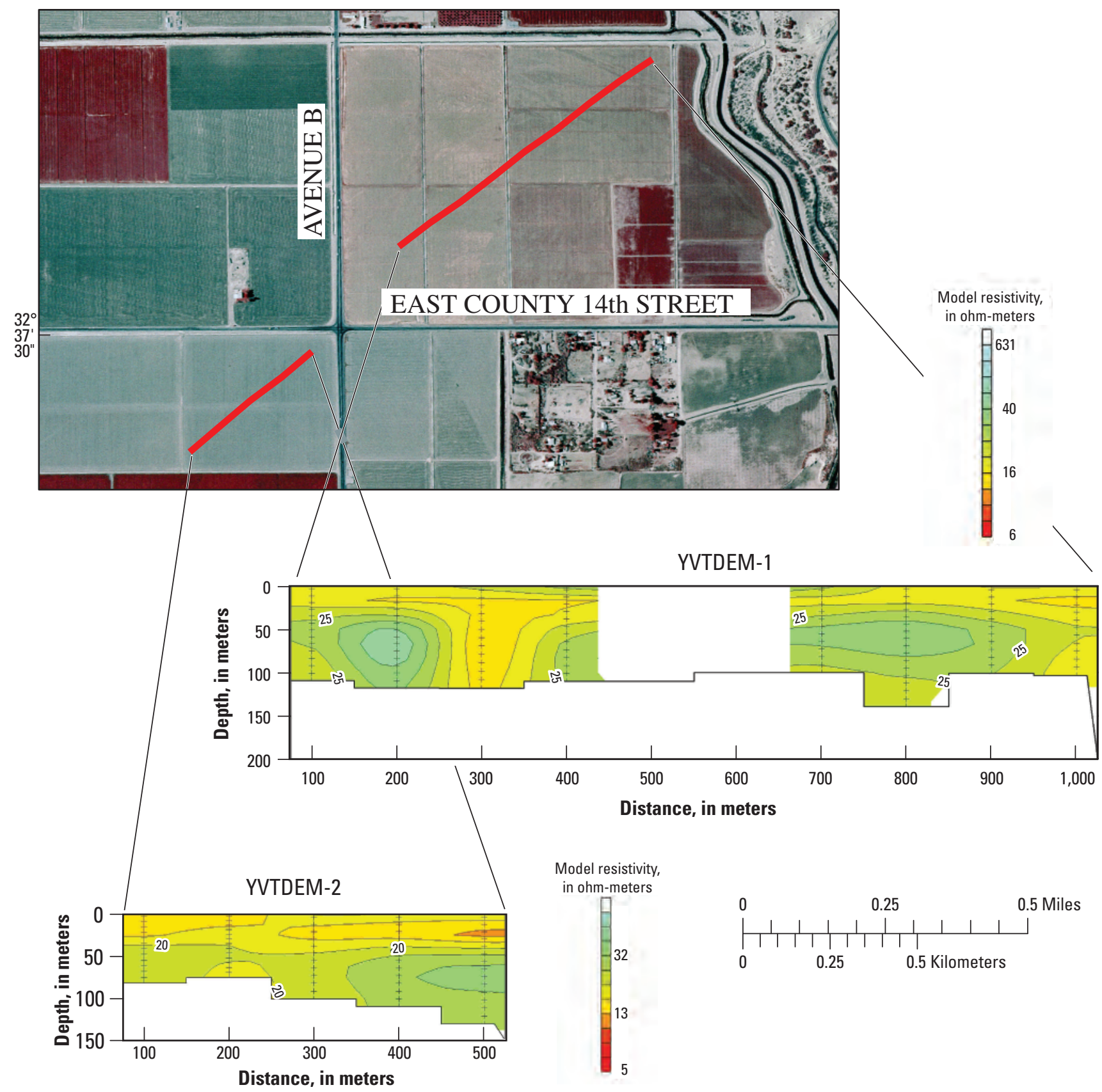

Figure 35. Time-domain electromagnetic surveys YVTDEM-1 and YVTDEM-2 on Avenue B and East County 14th Street. 


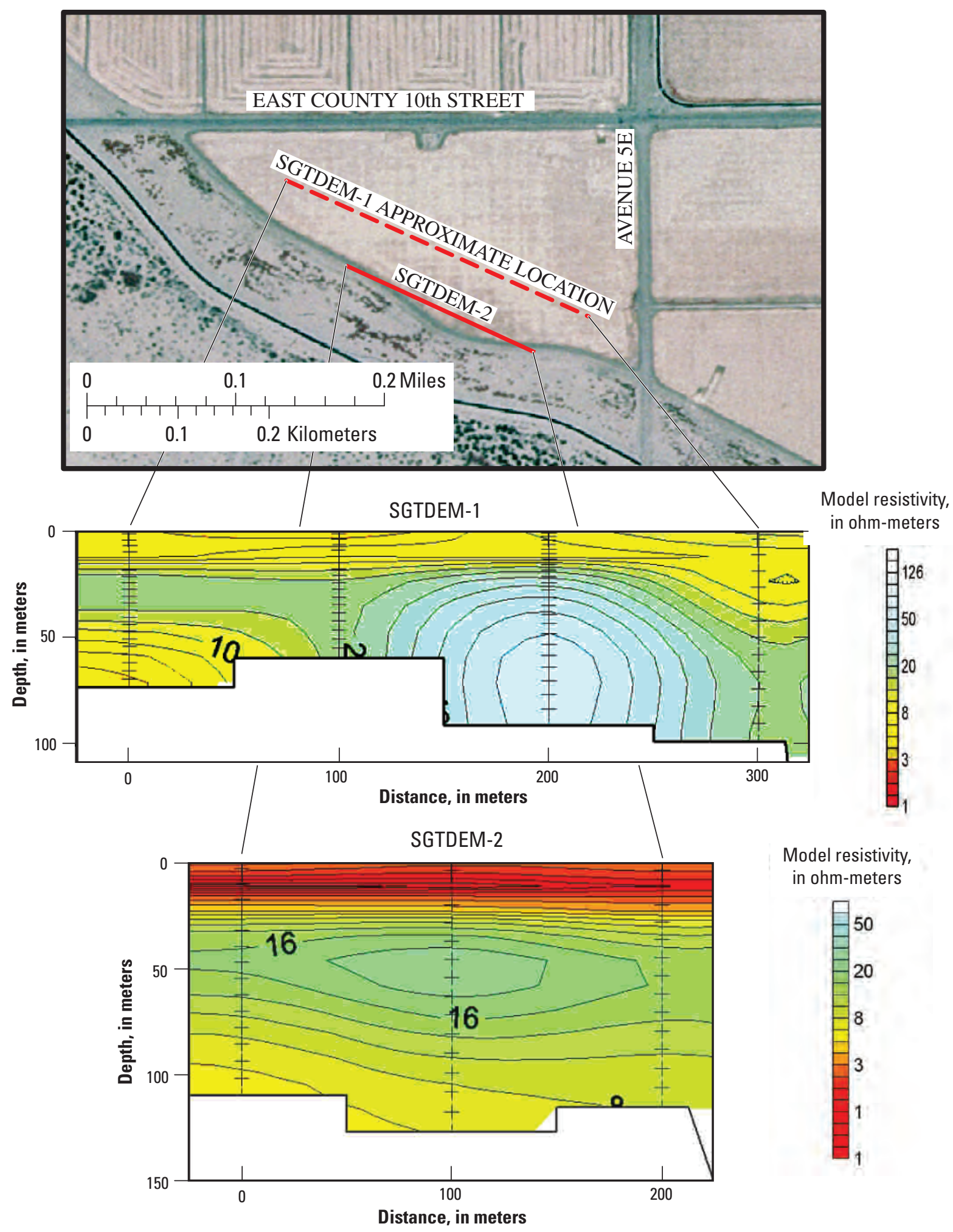

Figure 36. Time-domain electromagnetic surveys SGTDEM-1 and SGTDEM-2 at South Gila Valley. 
This page left blank intentionally. 


\section{Appendix C}

Well 242-2
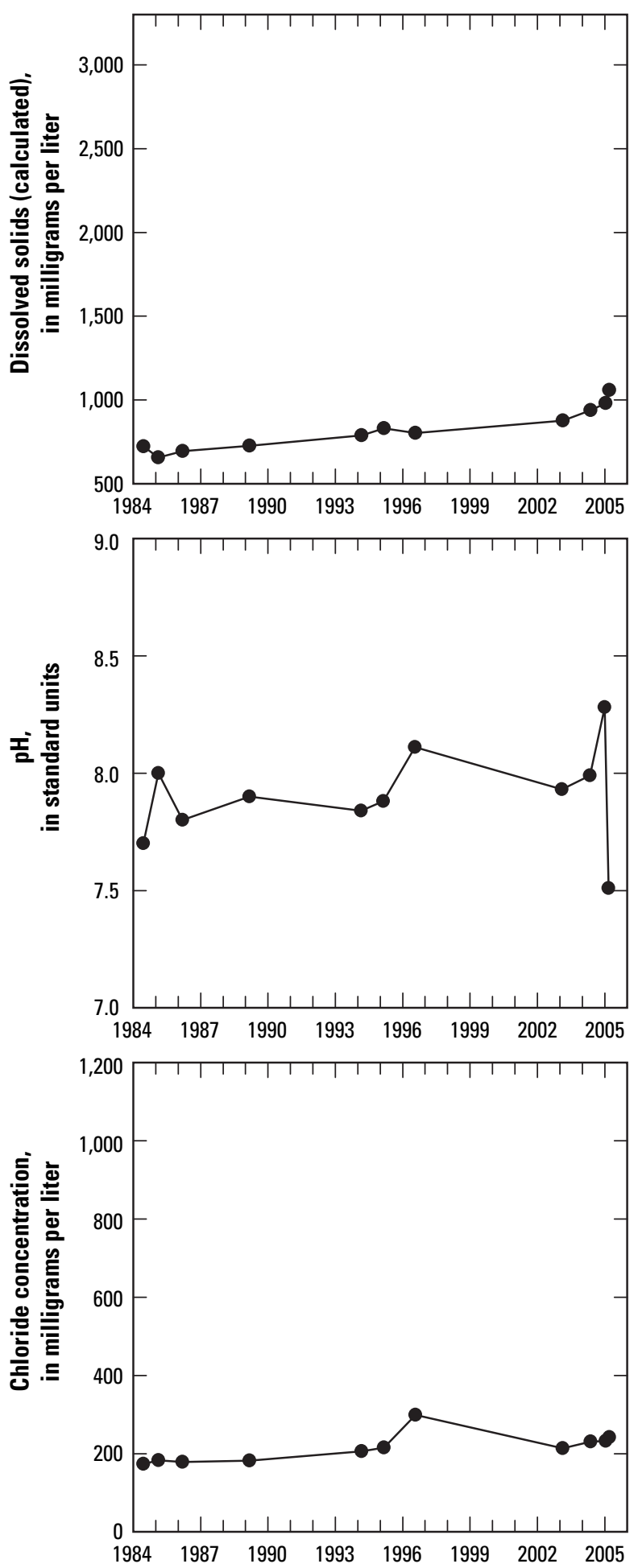
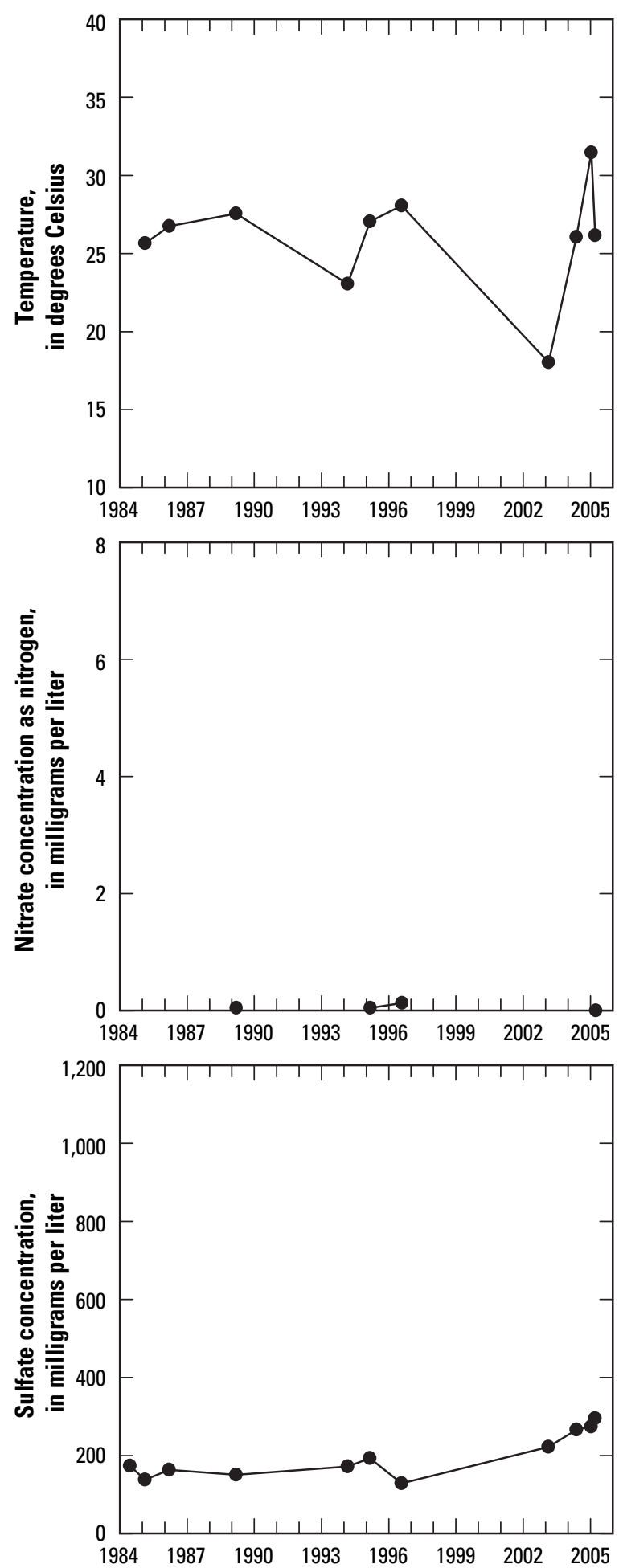

Figure 37. Water-chemistry data for well 242-2. 
Well 242-10
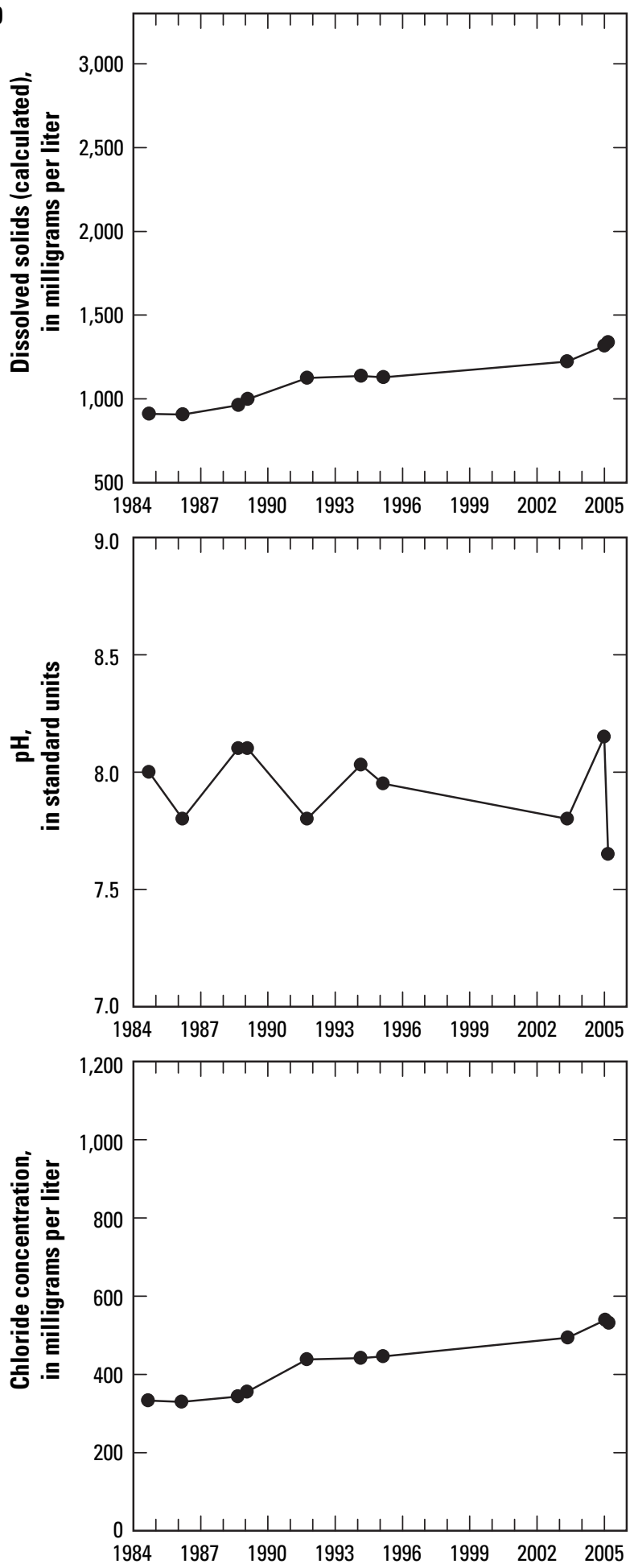
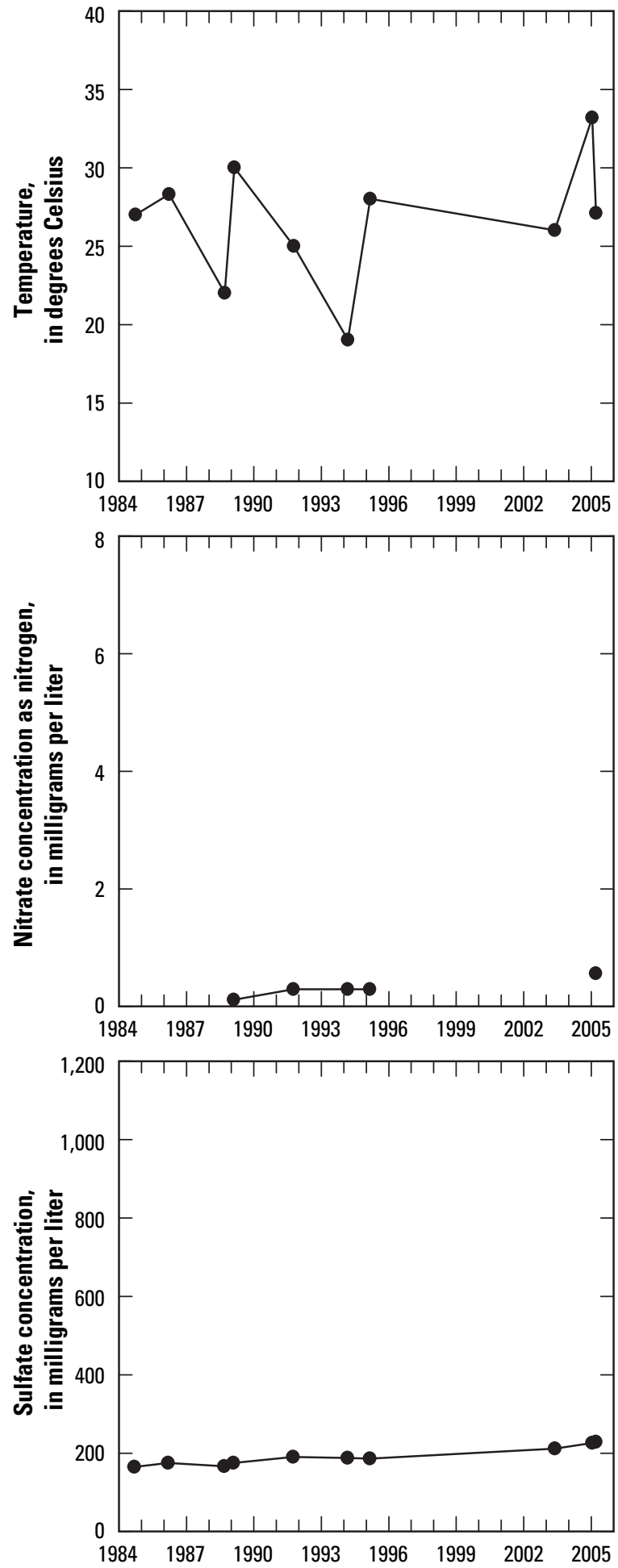

Figure 38. Water-chemistry data for well 242-10. 
Well 242-22
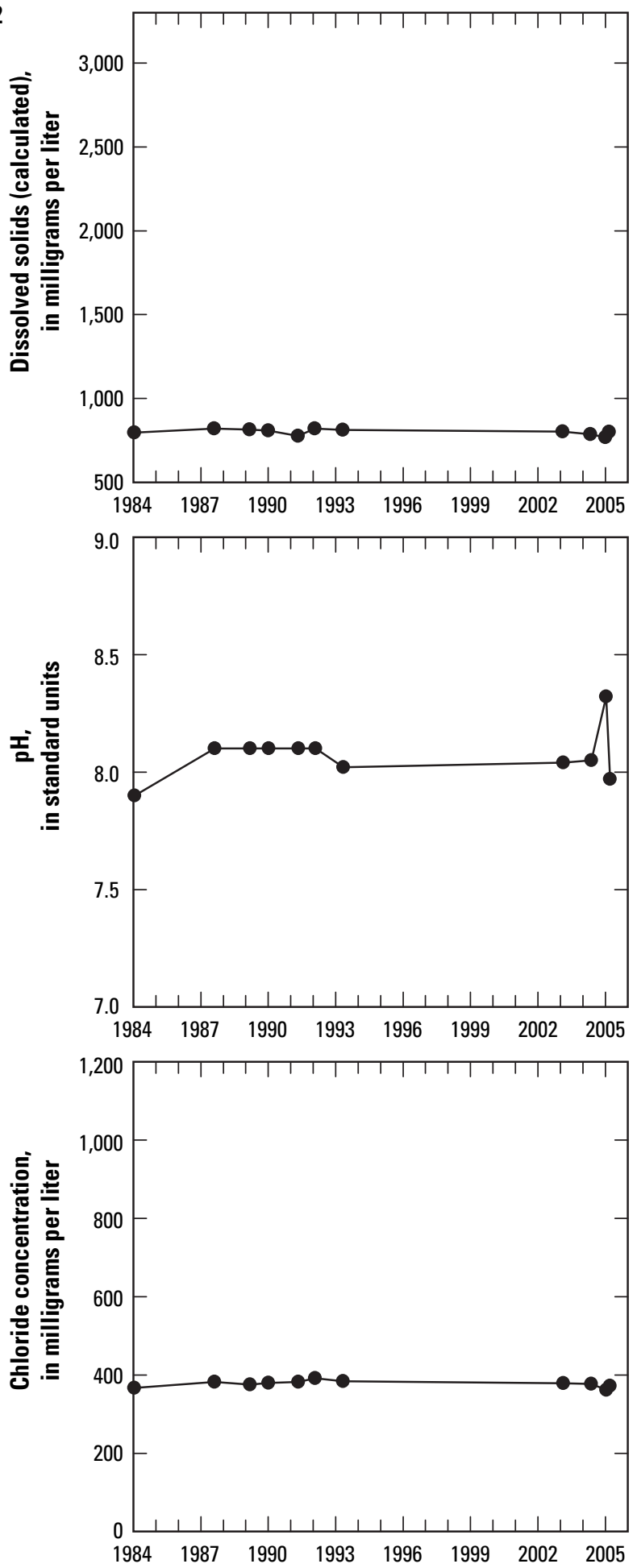
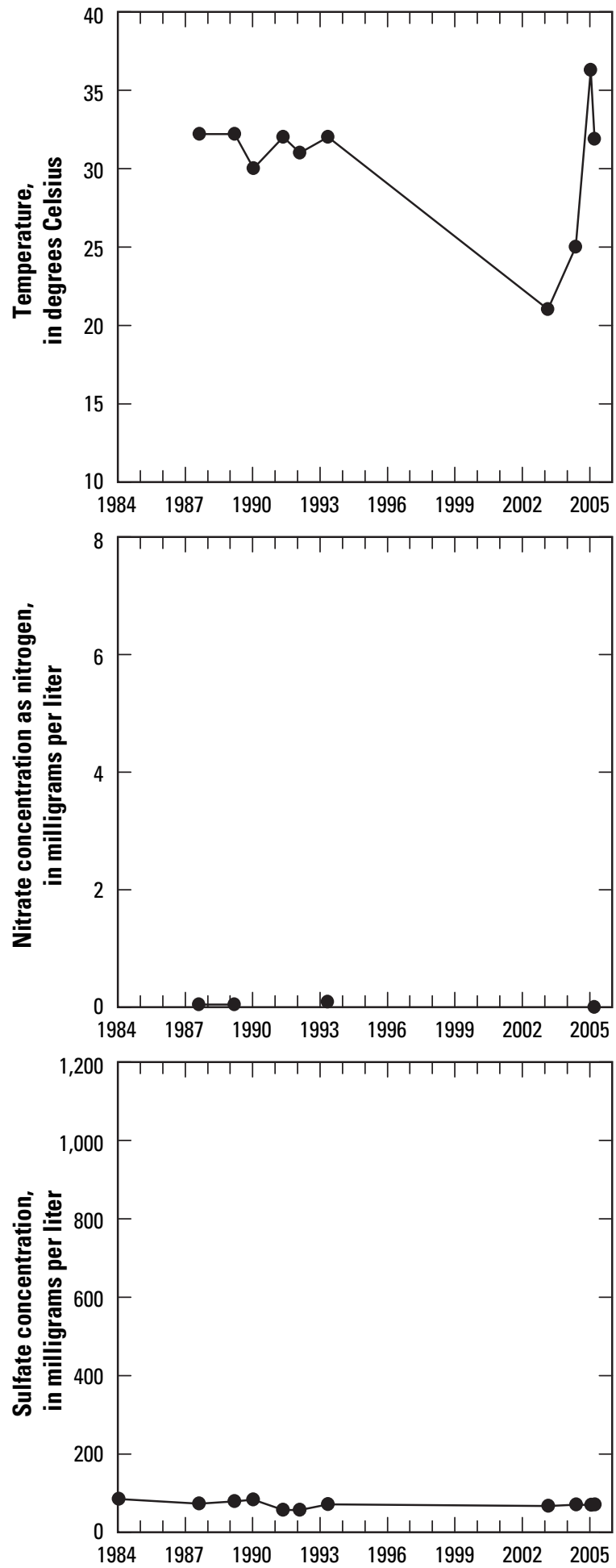

Figure 39. Water-chemistry data for well 242-22. 
Well DW-3
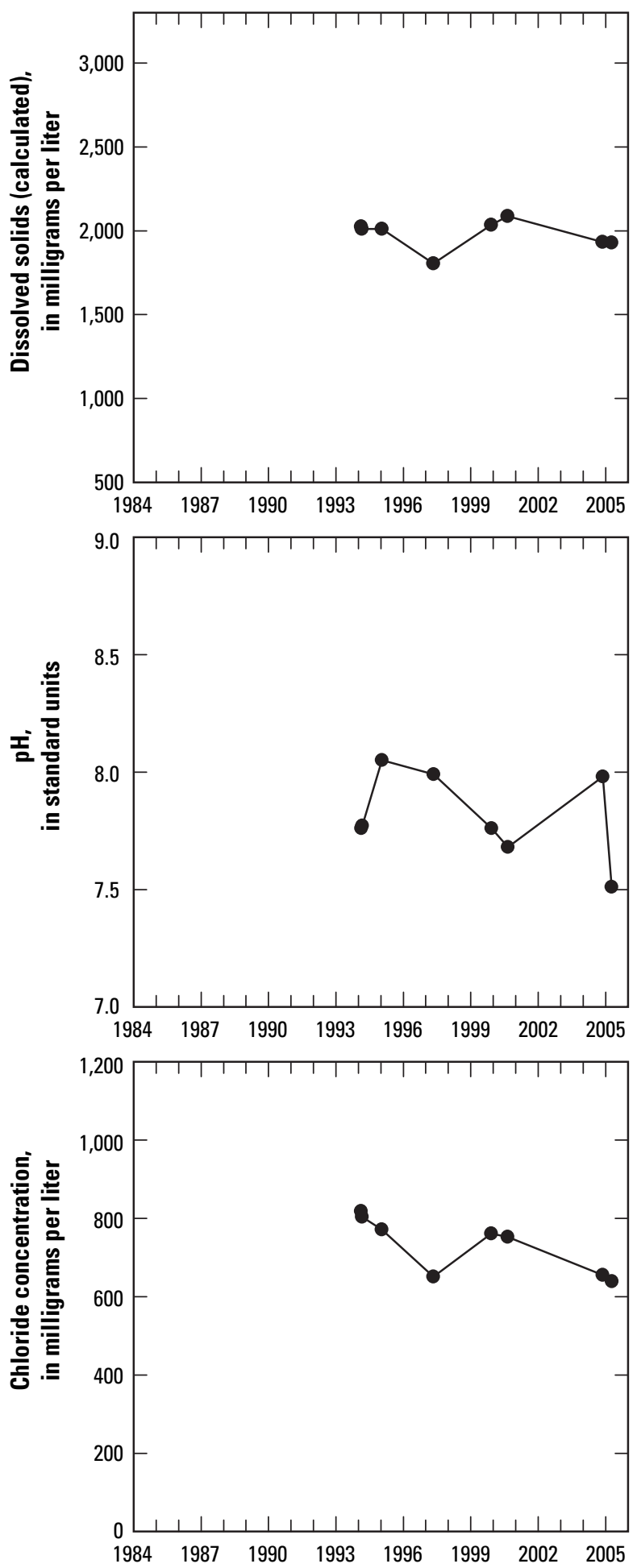
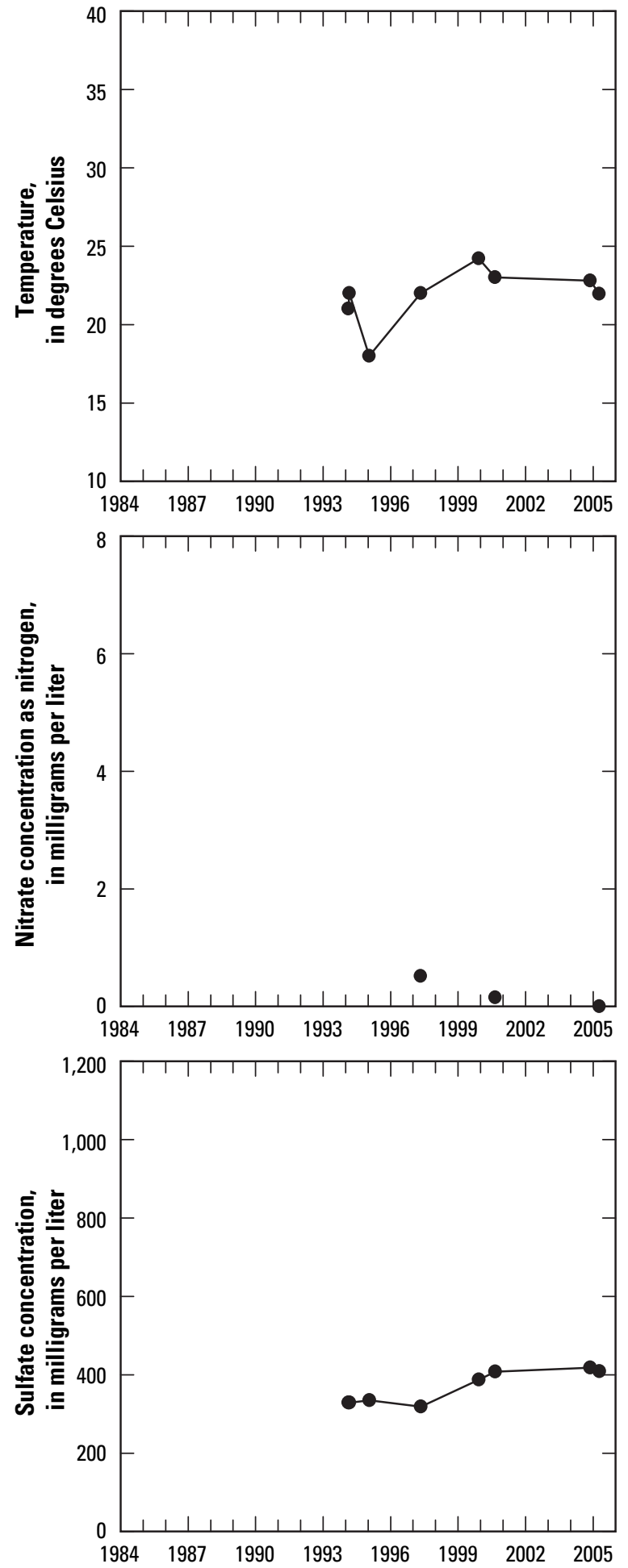

Figure 40. Water-chemistry data for well DW-3. 
Fortuna Pond
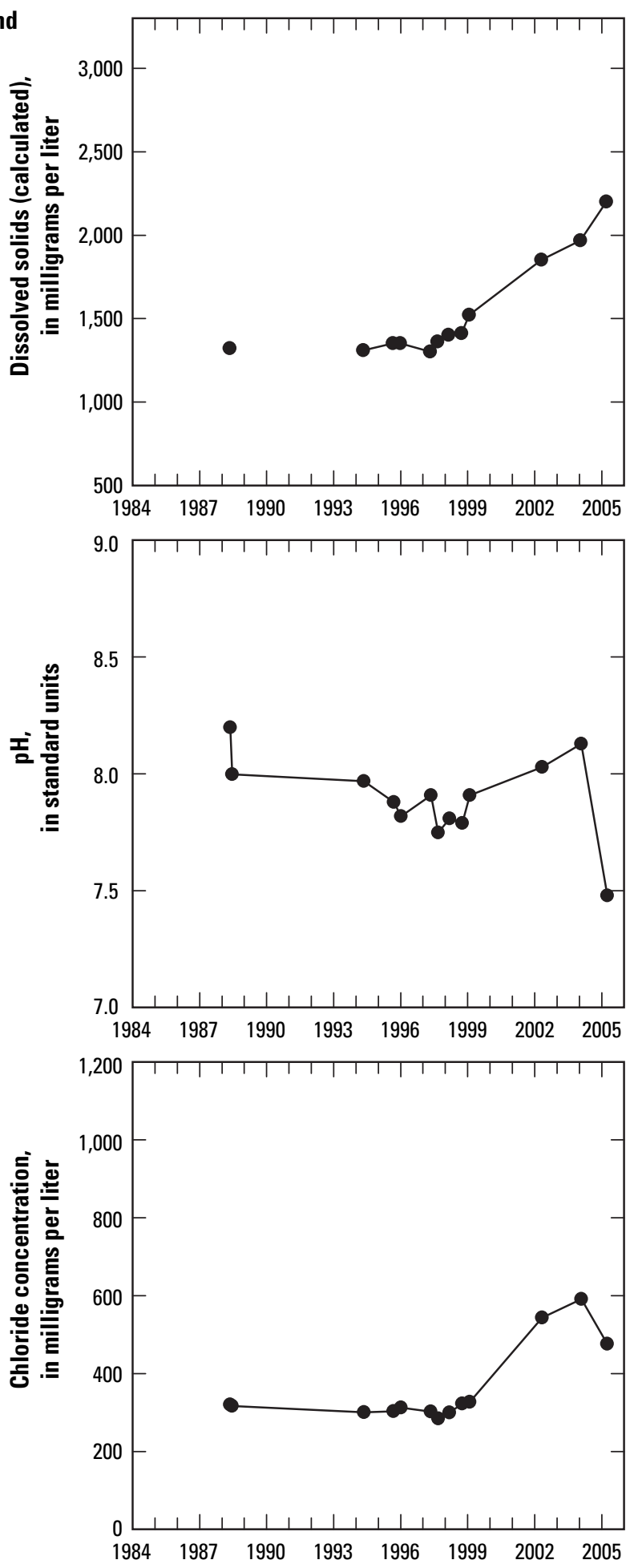
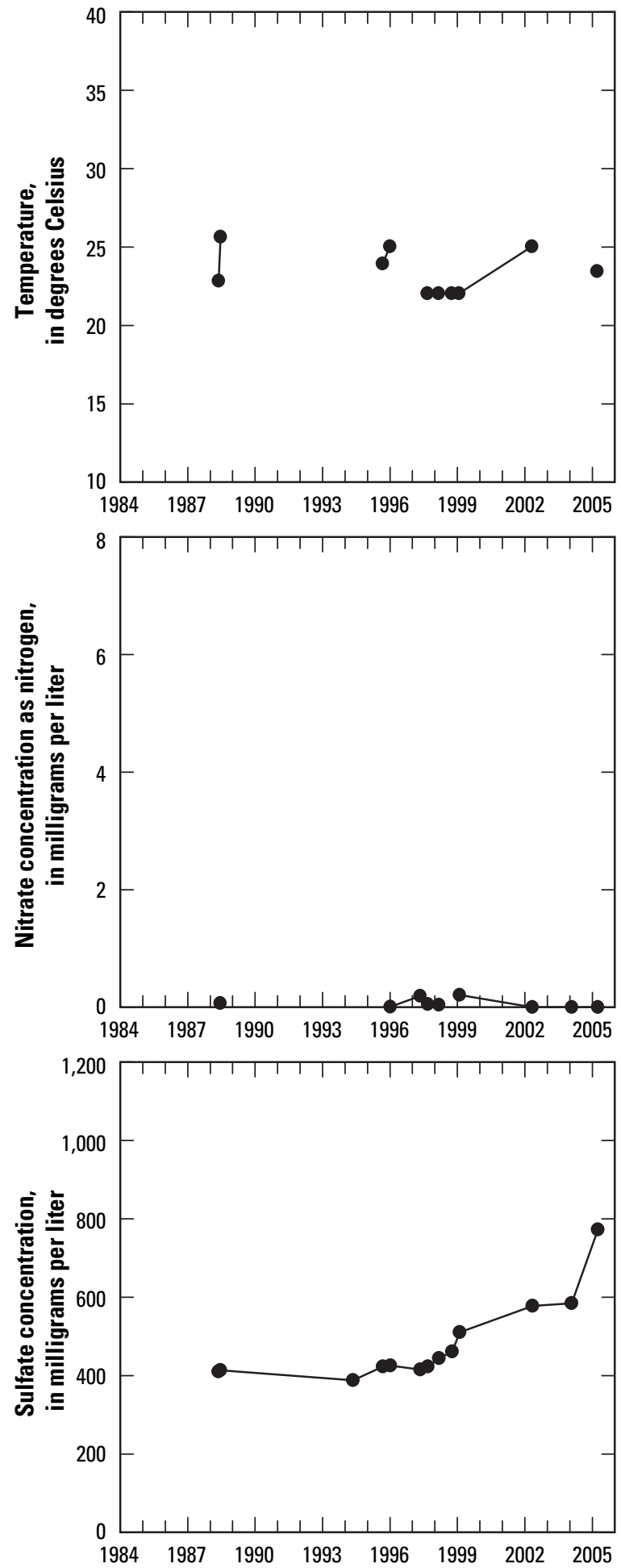

Figure 41. Water-chemistry data for well Fortuna Pond. 
Well SG-10r
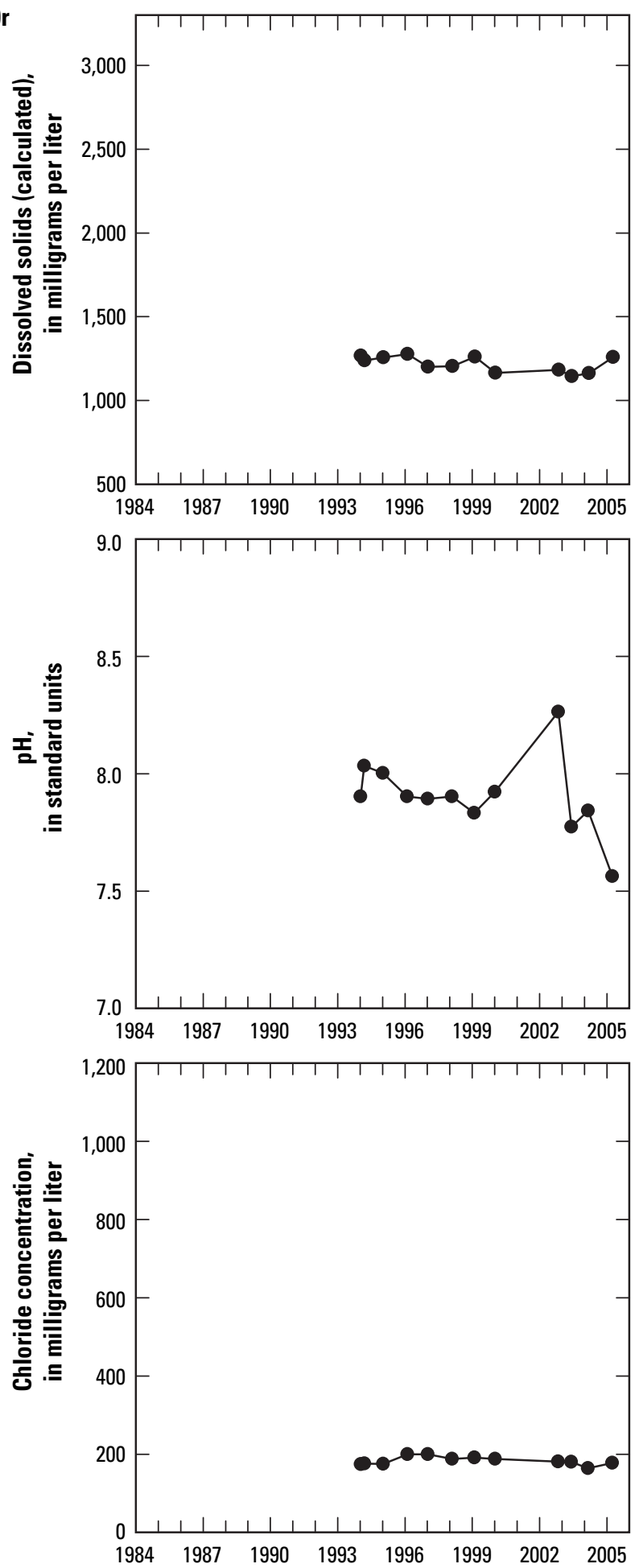
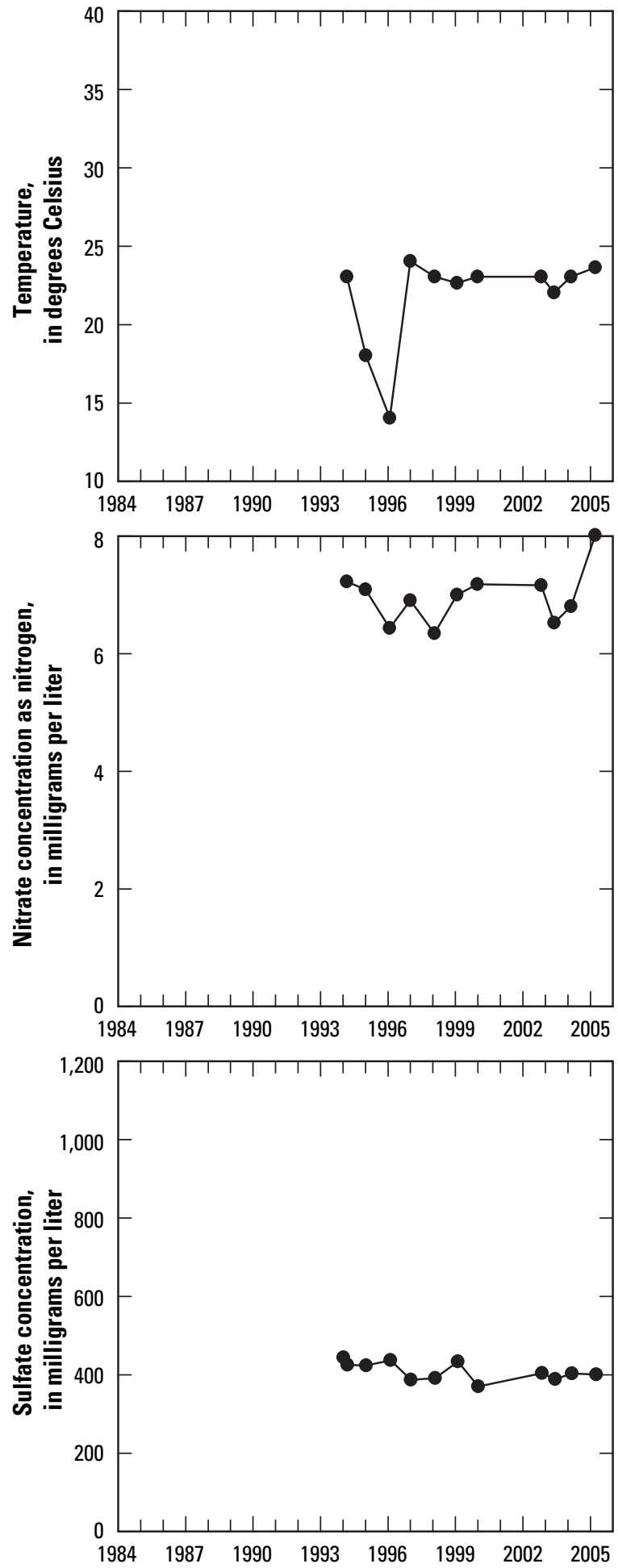

Figure 42. Water-chemistry data for well SG10r. 


\section{Well SG-709}
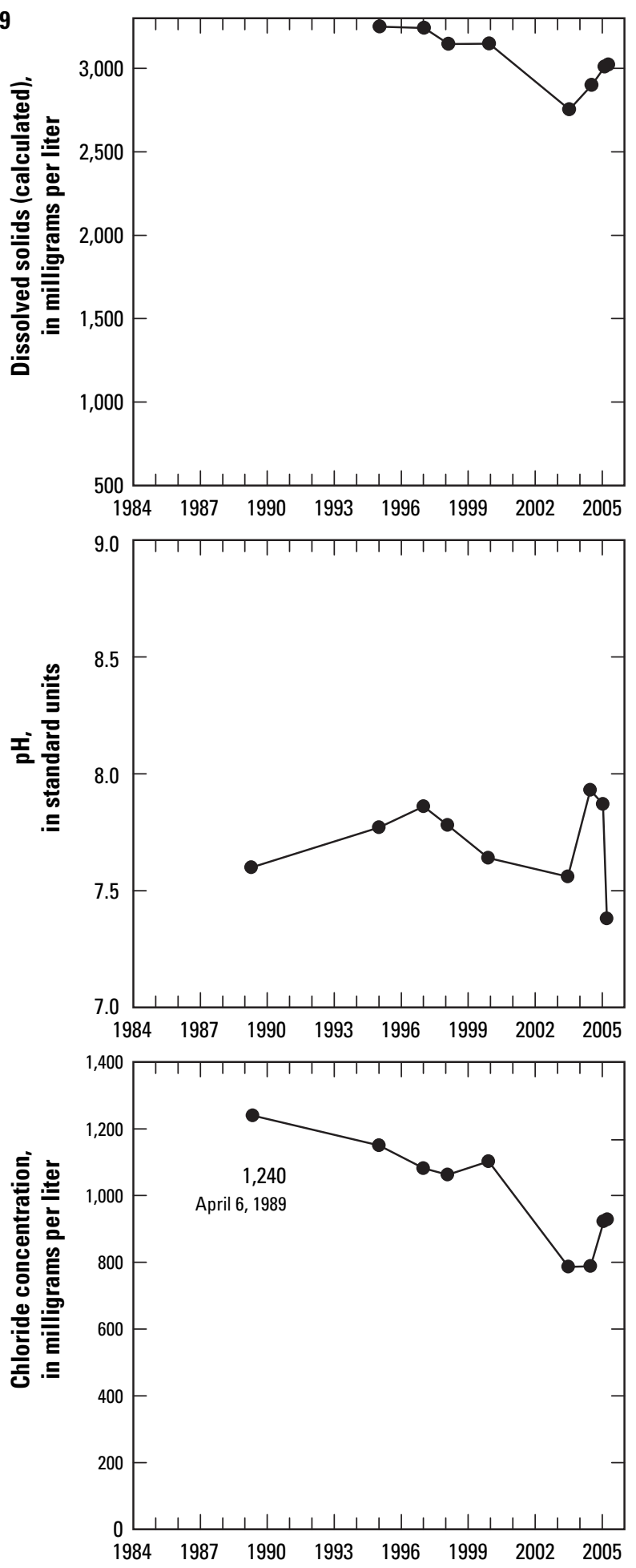
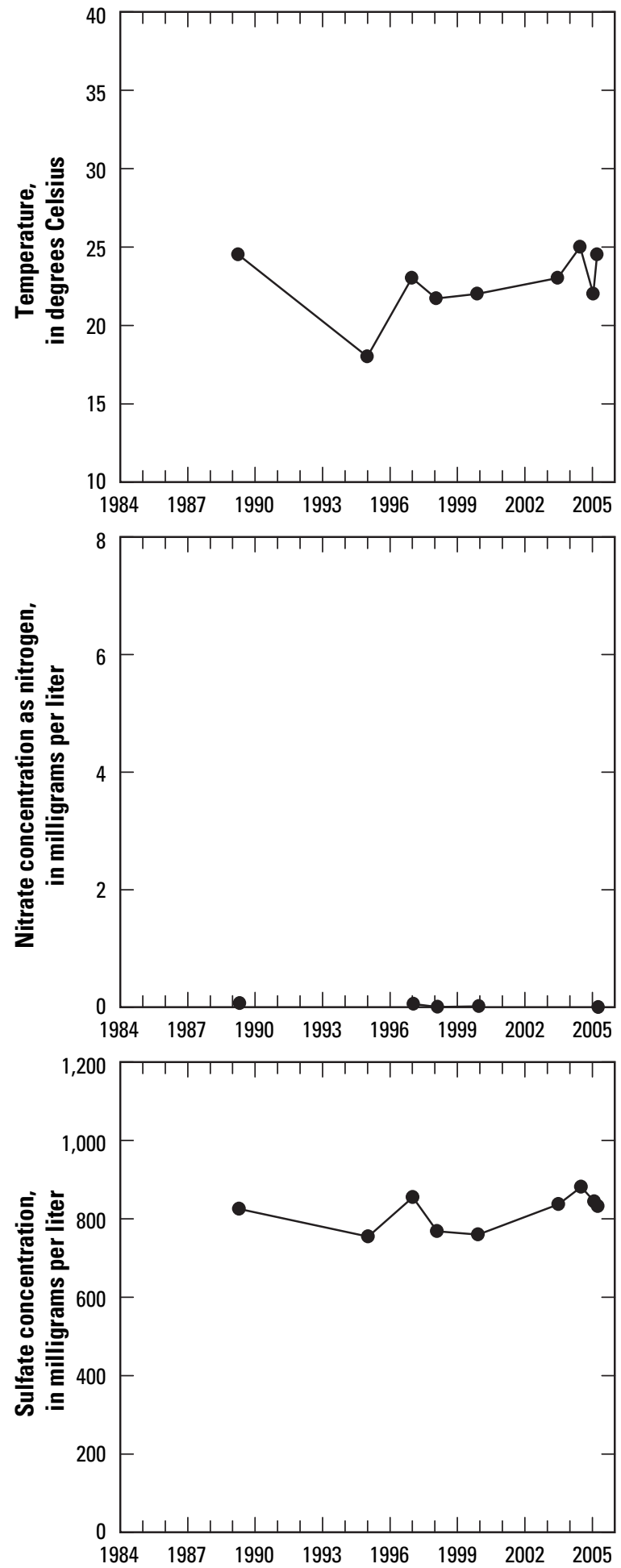

Figure 43. Water-chemistry data for well SG-709. 
YCWUA at 14th St.
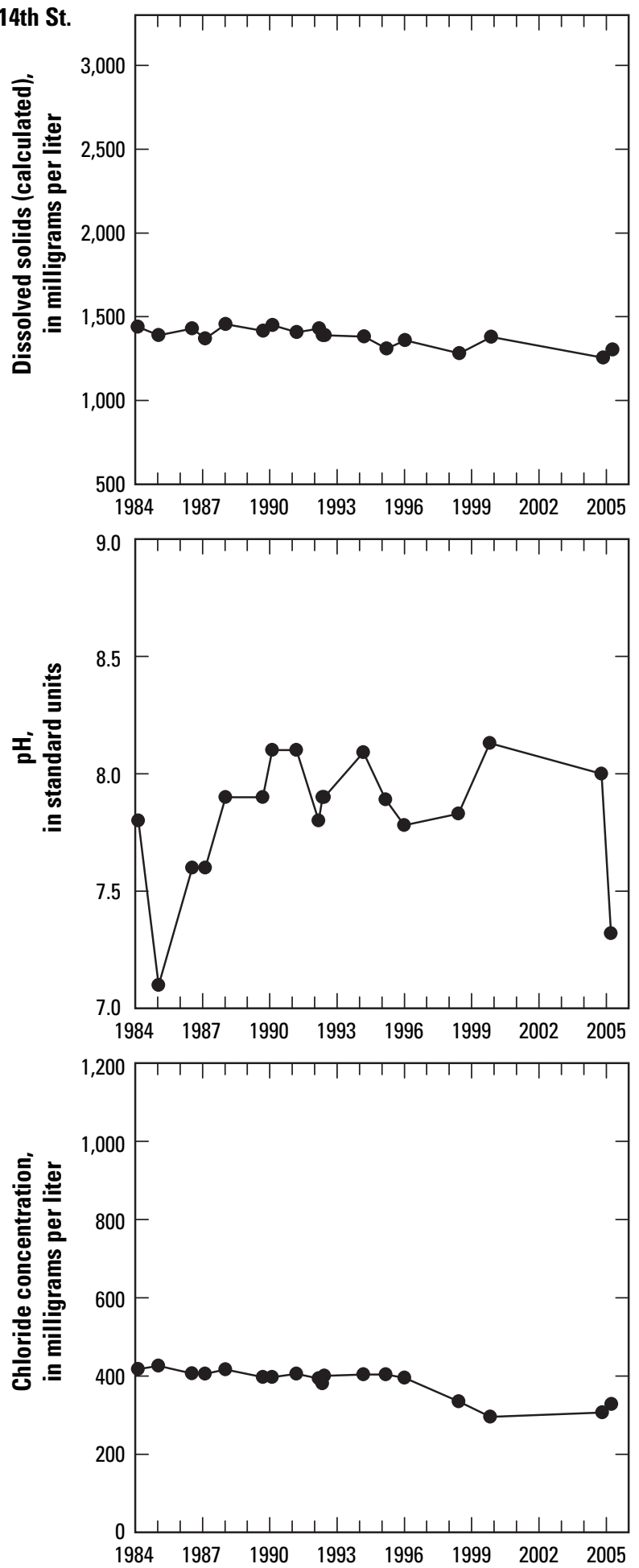
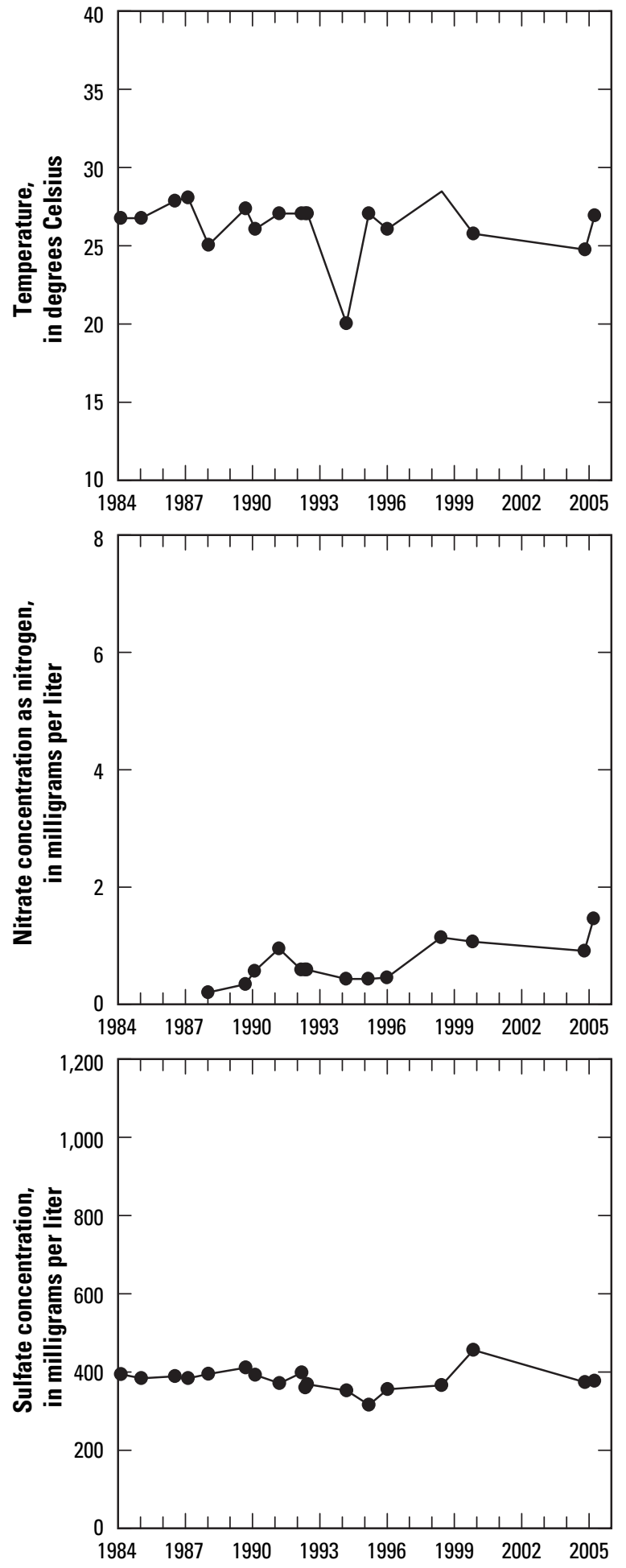

Figure 44. Water-chemistry data for well 14 1/4 Street at Yuma Valley. 
Well YM-10
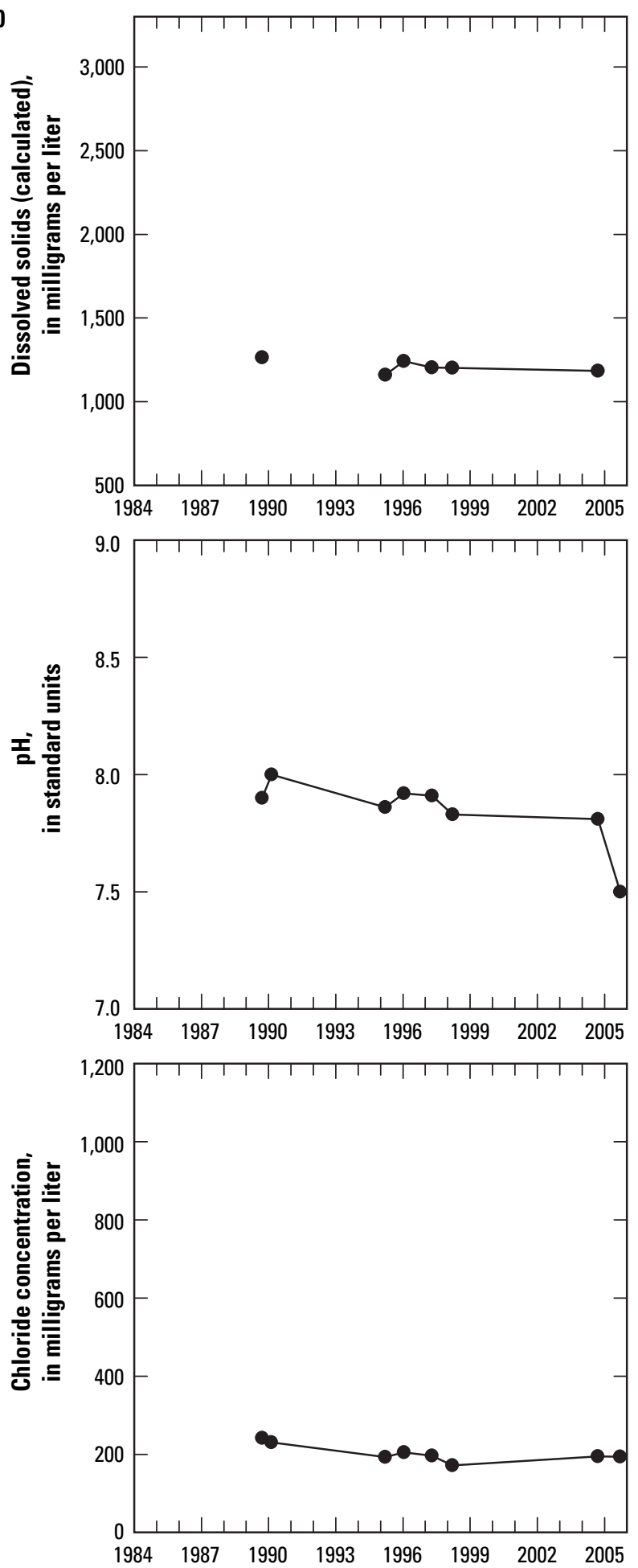
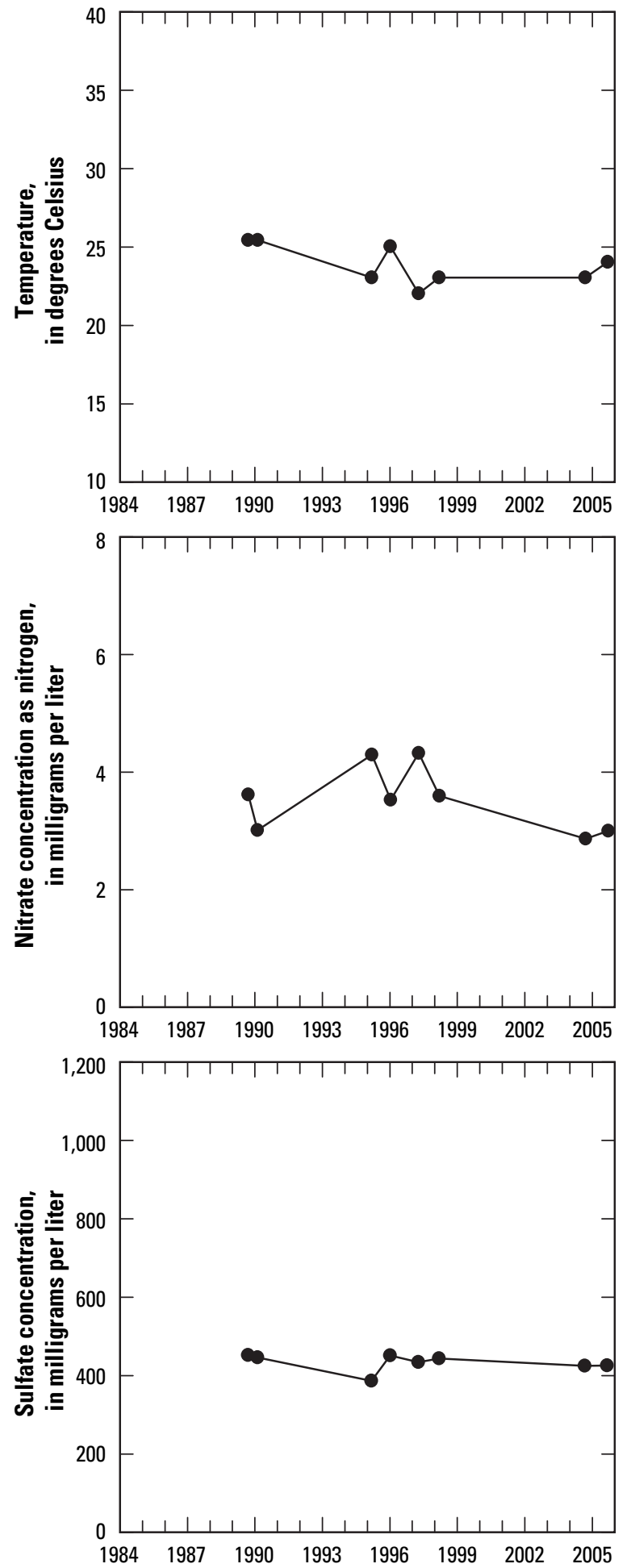

Figure 45. Water-chemistry data for well YM-10. 
Well YV-7r
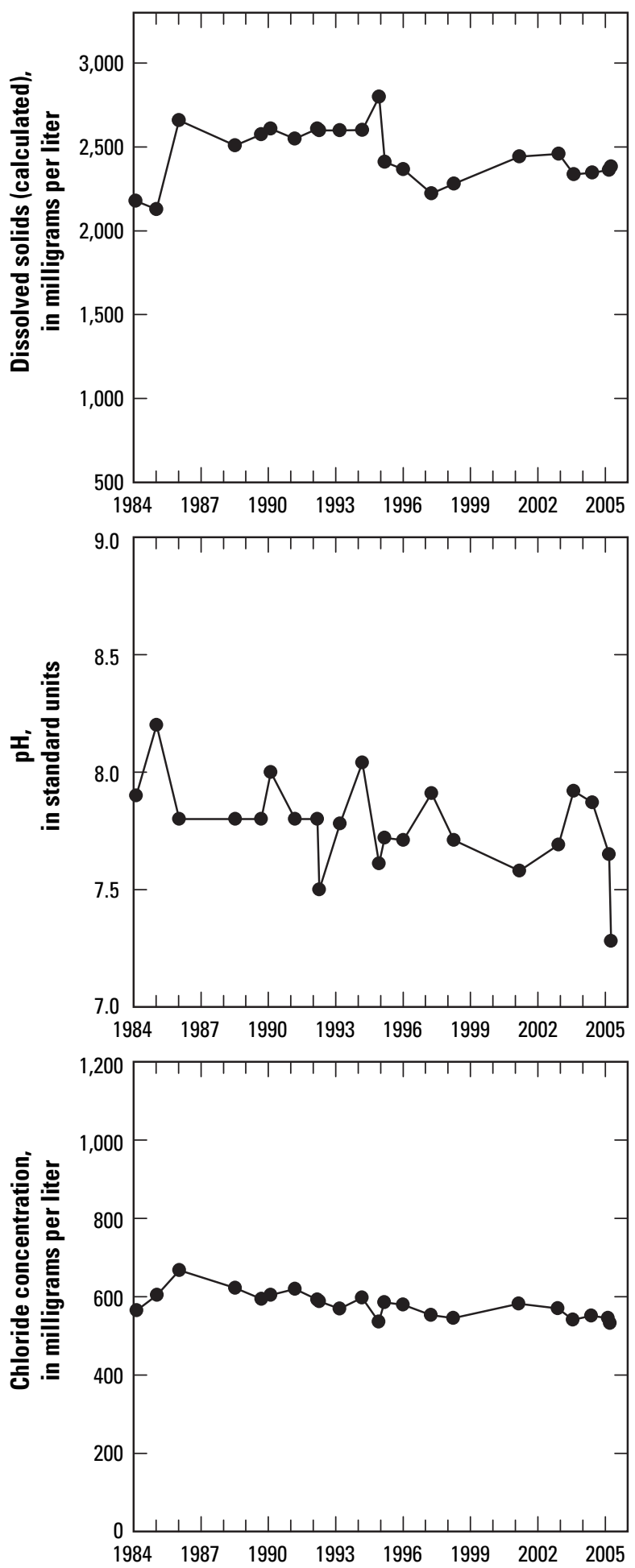
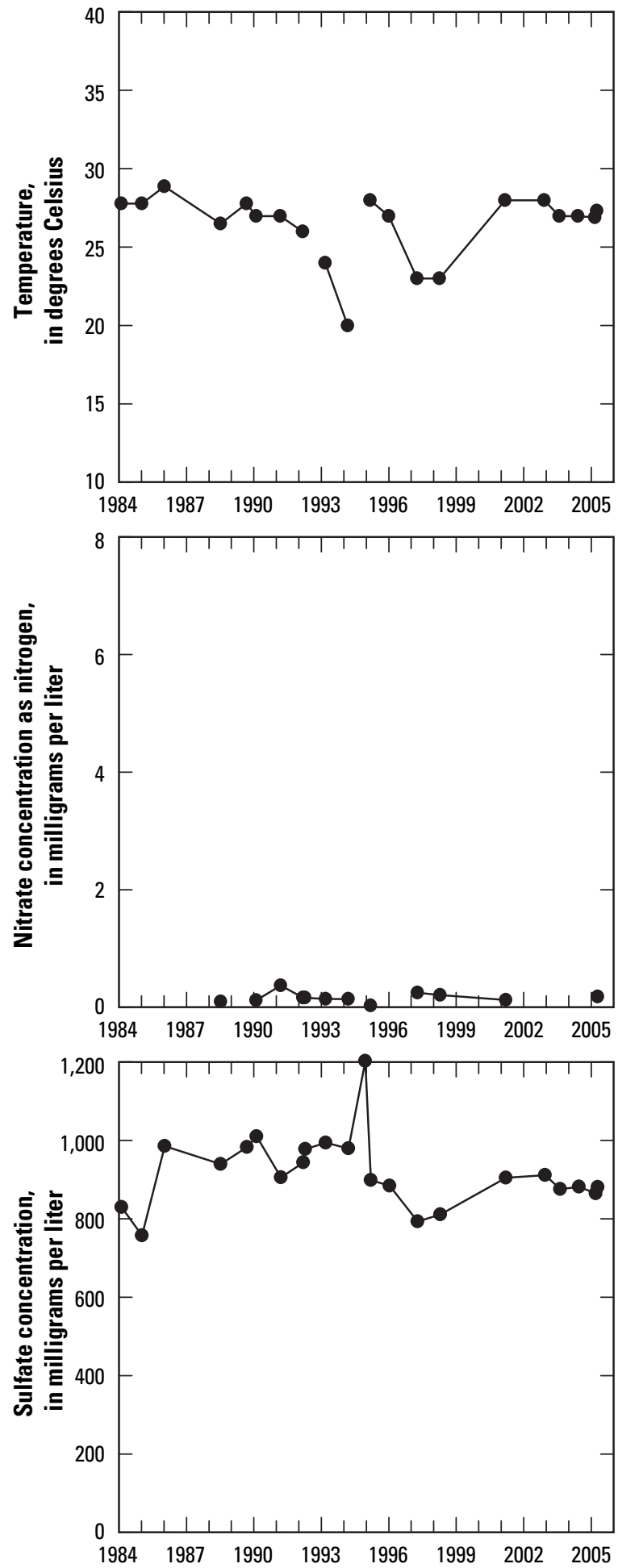

Figure 46. Water-chemistry data for well YV-7r at Yuma Valley. 
This page left blank intentionally. 
Manuscript approved for publication, June, 2006.

Prepared by the Reports Section, U.S. Geological Survey, Water Science Center, Tucson, Arizona.

For more information concerning the research in this report, contact the Arizona Water Science Center Director,

U.S. Geological Survey, 520 N. Park Ave., Suite 221

Tucson, AZ 85719

http://az.water.usgs.gov 
This page left blank intentionally. 


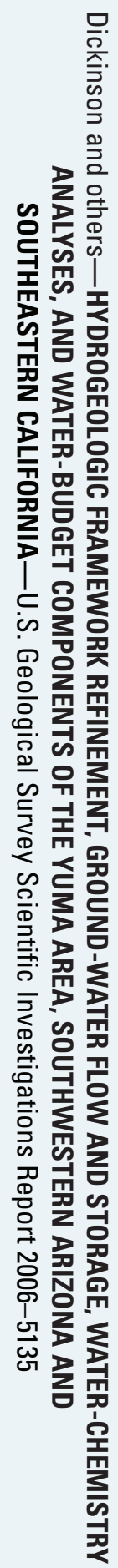

店.

은 꼬

홓촟

包云

召贸

叧㞧

Nㅛㅁำ

文

증 悬

옥 